\title{
Rhizophora mangle (Mangue vermelho) EM ÁREAS CONTAMINADAS DE MANGUEZAL NA BAIXADA SANTISTA
}

\author{
SANDRA PAVAN FRUEHAUF
}

Tese apresentada à Escola Superior de Agricultura "Luiz de Queiroz", Universidade de São Paulo, para obtenção do título de Doutor em Ecologia de Agroecossistemas.

PIR A C I C A B A

Estado de São Paulo - Brasil

Junho - 2005 


\title{
Rhizophora mangle (Mangue vermelho) \\ EM ÁREAS CONTAMINADAS DE MANGUEZAL \\ NA BAIXADA SANTISTA
}

\author{
SANDRA PAVAN FRUEHAUF \\ Engenheira Florestal \\ Orientador: Prof. Dr. HILTON THADEU ZARATE DO COUTO
}

Tese apresentada à Escola Superior de Agricultura "Luiz de Queiroz", Universidade de São Paulo, para obtenção do título de Doutor em Ecologia de Agroecossistemas.

PIR A C I C A B A

Estado de São Paulo - Brasil

Junho - 2005 
Dados Internacionais de Catalogação na Publicação (CIP) DIVISÃO DE BIBLIOTECA E DOCUMENTAÇÃO - ESALQ/USP

Fruehauf, Sandra Pavan

Rhizophora mangle (Mangue vermelho) em áreas contaminadas de manguezal na Baixada Santista / Sandra Pavan Fruehauf. - - Piracicaba, 2005.

223 p. : il.

Tese (doutorado) - - Escola Superior de Agricultura Luiz de Queiroz, 2005. Bibliografia.

1. Degradação ambiental 2. Ecossistema de mangue 3. Halofita 4. Meio ambiente - Qualidade 5. Metais - Contaminação 6. Poluição ambiental 7. Regeneração natural I. Título

CDD 574.52636

"Permitida a cópia total ou parcial deste documento, desde que citada a fonte - O autor" 
Ao men filho Lucas que chegou em meio a minha caminhada transformando minhas perspectivas...

E ao men marido George que trílha comigo as minhas caminhadas, partilhando cada nova perspectiva... 


\section{AGRADECIMENTOS}

Ao Prof. Dr. Hilton Thadeu Z. do Couto pela excelente orientação, apoio e amizade;

Ao pesquisador Geraldo G. J. Eysink pela contribuição na definição das linhas do trabalho;

À Profa. Dra. Sandra Aparecida Lieberg pelas contribuições técnicas e incentivo;

Ao colega Luis Eduardo Carrer pela contribuição e dinamismo constantes em campo;

Às colegas Ana Paula C. Packer e Camila de C. B. Levy pela realização das análises químicas;

À colega Maria Luíza S.Silva e ao Prof.Dr. Pablo Vidal Torrado pela parceria e realização da coleta e análises de solos;

Aos estagiários: Michelli de Freitas, Carlos Felipe M. Gimenez, Fábio Luiz Cassiano, Mayra Vidal Giannini, Andreza Moleiro Araújo, Karem K. Barbosa que participaram de forma entusiástica nos trabalhos de campo e escritório;

Ao amigo Valdir Pelicas, barqueiro e técnico de campo, cujo apoio foi fundamental e a acolhida sempre calorosa;

Às colegas Oriana Ap. Fávero pelas contribuições técnicas e revisão do texto final;

Ao colega George Lentz C. Fruehauf pelas contribuições técnicas e incondicional apoio;

À empresa Lentz Meio Ambiente pelo aporte logístico;

À CAPES pela concessão de bolsa;

À FAPESP pela concessão de Auxílio à pesquisa;

E a todos os demais amigos e colegas que contribuíram na realização deste trabalho, 


\section{SUMÁRIO}

Página

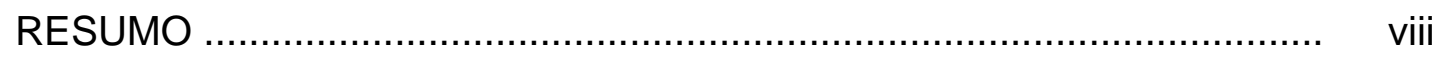

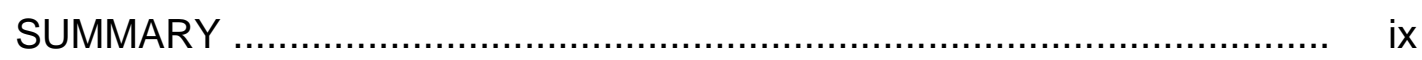

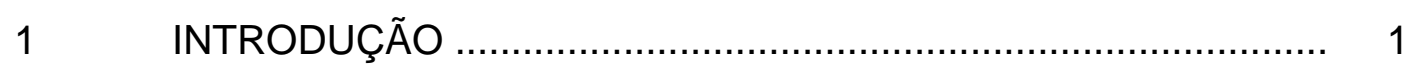

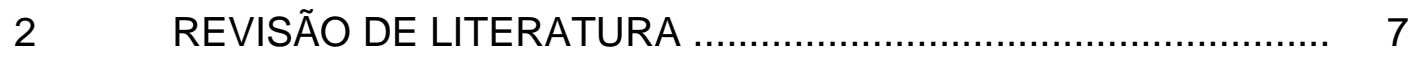

$2.1 \quad$ O Ecossistema Manguezal ........................................... 7

2.1.1 Histórico .................................................................... 7

2.1.2 Mata Atlântica e o ecossistema associado Manguezal ............... 10

2.1.3 Caracterização dos Manguezais ........................................... 12

2.1.4 Distribuição mundial e no Brasil ........................................... 13

2.1.5 Sistemas de classificação ................................................... 21

2.1 .6 Diversidade ................................................................. 23

2.1.7 Zonação ...................................................................... 28

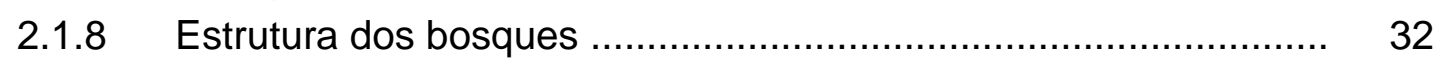

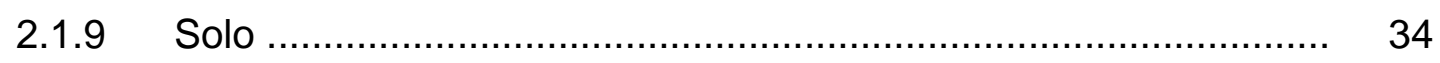

2.1.10 Adaptações das espécies ................................................ 40

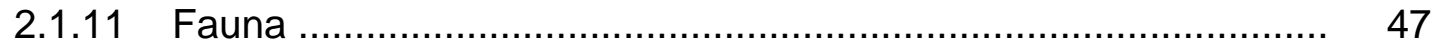

2.1.12 Função ecológica e sócio-econômica ....................................... 48

2.1 .13 Legislação ................................................................. 50

2.1.14 Tensores naturais e antrópicos ........................................... 51

2.1.15 Situação quanto à degradação ............................................ 53

$2.2 \quad$ Contaminação por metais ..................................................... 55

2.2.1 Os metais ......................................................................... 55

2.2.2 O Manguezal como armazenador de metais ........................... 59

2.2.3 Contaminação e sintomas ..................................................... 60

2.2.4 Comportamento dos metais pesados no meio e na planta .......... 61

2.3 Mortalidade em plantios de propágulos ................................. 68 


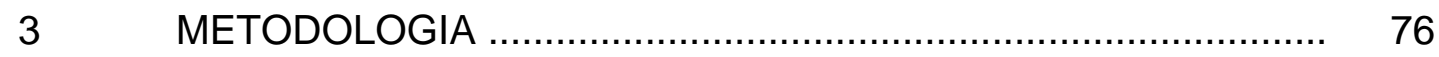

3.1 Passos metodológicos …………………………………........ 76

3.2 Detalhamento da metodologia .............................................. 79

3.3 Cronologia dos eventos ……............................................... 123

$4 \quad$ RESULTADOS E DISCUSSÃO …………............................ 125

4.1 Fotointerpretação digital ..................................................... 125

$4.2 \quad$ Coleta e mensuração dos propágulos ......................................... 131

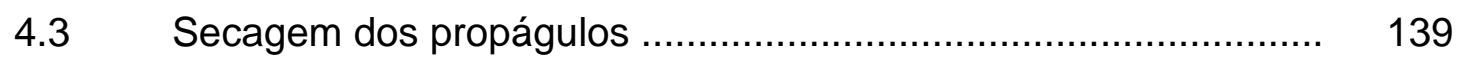

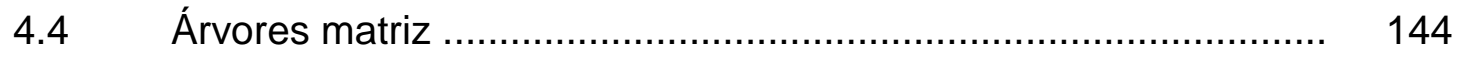

$4.5 \quad$ Inventário florestal ......................................................... 152

4.6 Plantio de propágulos ........................................................ 164

4.7 Análise química do solo .......................................................... 177

4.8 Análise química de água e organismos ................................... 181

4.9 Análise química de material vegetal ........................................ 185

4.10 Qualidade ambiental ...................................................... 199

4.11 Observação adicional - Lagartas ............................................. 202

5 CONCLUSÕES ................................................................... 205

REFERÊNCIAS BIBLIOGRÁFICAS ........................................................ 213 


\title{
Rhizophora mangle (Mangue vermelho) EM ÁREAS CONTAMINADAS DE MANGUEZAL DA BAIXADA SANTISTA
}

\author{
Autora: SANDRA PAVAN FRUEHAUF \\ Orientador: Prof. Dr. HILTON THADEU ZARATE DO COUTO
}

\section{RESUMO}

Os Manguezais são ecossistemas de grande importância ecológica, social e econômica. Tendo em vista que estas áreas vêm sofrendo degradações, em especial a contaminação por resíduos e efluentes contendo metais pesados, que interferem na estabilidade ambiental, torna-se importante identificar $o$ nível de interferências destes contaminantes sobre o desenvolvimento dos bosques que colonizam tais áreas. Assim sendo, a proposta deste estudo é avaliar os efeitos de metais sobre o estabelecimento de propágulos, mudas e indivíduos adultos de Rhizophora mangle (Mangue vermelho), espécie de ampla dispersão em Manguezais, buscando verificar a qualidade ambiental do ecossistema. Foram selecionadas três áreas localizadas nos municípios de Cubatão e São Vicente, na Baixada Santista - SP, grande pólo industrial regional e maior área portuária do país, além de uma área testemunha localizada na Ilha do Cardoso, Cananéia - SP. A Qualidade ambiental, na inexistência de um padrão de concentração de metais em plantas, foi avaliada com base concentração de cinco diferentes metais nos compartimentos solo, água, material vegetal e organismos, comparativamente entre áreas. A pior situação foi constatada para área localizada no Canal da Cosipa, intermediária para o Rio Cascalho e melhor no Manguezal do Rio Mariana. Verificou-se que a contaminação por metais está associada ao padrão do bosque (alterado em função do grau de degradação), sendo este um dos tensores ambientais responsáveis pela reposta negativa no estabelecimento de R. mangle na Baixada Santista. 


\section{Rhizophora mangle (RED MANGROVE) IN CONTAMINATED AREAS OF MANGROVE FROM BAIXADA SANTISTA}

Author: SANDRA PAVAN FRUEHAUF

Adviser: Prof. Dr. HILTON THADEU ZARATE DO COUTO

\section{SUMMARY}

Mangroves are ecosystems of great ecological and economical importance. Considering that these areas have been degradated, specially by deposition of solid wastes and liquid effluents containing heavy metals it becomes important to identify to what level these contaminants interfere on the development of plants that colonize such environs. Therefore, the aim of this study is assess the effects of heavy metals on the development of "propágulos", "plântulas" and "mudas" of the Mangue vermelho (Rhizophora mangle), specie which is widely spread on mangroves, in order to determine environmental quality at the mangrove. Three study areas with considerable degradation were selected in the municipalities of Cubatão and São Vicente, in the Baixada Santista - SP, industrial coastal region and greatest sea port of Brazil and a background non - contaminated area located on the Cardoso Island and in Cananéia. Due to the absence of a metal concentration standard for plants, environmental quality was assessed by comparison between five different metals determined in the soil, water, vegetation and organisms at the selected sites. Worst environmental conditions were found at the Cosipa Channel, intermediate at the Cascalho river and best at Mariana river. It was verified that metal concentration was associated with mangrove development (altered as a function of degradation level), being this a cause for the decreased establishment of R.mangle at the Baixada Santista area. 


\section{INTRODUÇÃO}

A área ocupada por Manguezais em todo o mundo situa-se em torno de $162.000 \mathrm{Km}^{2}$. São mais expressivos na faixa entre os trópicos de Câncer e Capricórnio. No Brasil são encontrados ao longo de quase toda costa litorânea, em extensões de 10.000 a $25.000 \mathrm{Km}^{2}$, dependendo da fonte consultada.

Este ambiente pode ser caracterizado como:

"Ecossistema costeiro, de transição entre os ambientes terrestre e marinho, característico de regiões tropicais e subtropicais, sujeito ao regime das marés. É constituído de espécies lenhosas típicas (angiospermas), além de micro e macroalgas (criptógamas), adaptadas à flutuação de salinidade e caracterizadas por colonizarem sedimentos predominantemente lodosos, com baixos teores de oxigênio. Ocorre em áreas costeiras abrigadas e apresenta condições propícias para alimentação, proteção e reprodução de muitas espécies animais, sendo considerado importante transformador de nutrientes em matéria orgânica e gerador de bens e serviços" (Schaeffer-Novelli, 1995 - p. 7).

As plantas arbóreas halófitas que caracterizam os Manguezais brasileiros são o Mangue vermelho (Rhizophora mangle Linn), o Mangue preto ou Siriúba (Avicennia schaweriana Stapf \& Leechman) e o Mangue branco ou Tinteiro (Laguncularia racemosa Gaertn), sendo que a distância máxima de penetração da água salgada, através da amplitude das marés, determina o limite do Manguezal em relação à terra. As condições ambientais para sua formação, incluem ainda clima intertropical, substratos aluviais, locais de baixa energia de ondas e marés, presença de água salobra e grande amplitude de marés. 
A colonização das áreas brejosas com bosques de Manguezal, dá-se por meio da dispersão de propágulos, que ao se desprenderem da planta-mãe, podem fincar-se na lama ou serem levados pelas marés, fixando-se em locais mais distantes. Para continuarem seu desenvolvimento, necessitam de condições propícias referentes à imersão, salinidade, tipo de solo, insolação, vento, ação de herbívoros, entre outros fatores ambientais, que irão condicionar a taxa de mortalidade das plântulas.

Apesar do reduzido número de espécies vegetais encontradas nestas áreas, a fauna associada é muito variada, desde formas microscópicas até grandes peixes, aves, répteis e mamíferos, ocupando o sedimento, a água, as raízes, troncos e copas das árvores. Estes ambientes desempenham uma importante função na produtividade dos ecossistemas integrados, especialmente os costeiros.

Além de sua importância ecológica já mencionada, ressalta-se a sócioeconômica, pelo benefício direto e indireto da produtividade pesqueira (peixes, camarões, caranguejos e ostras), para as populações que dele dependem e pela função de retenção de sedimentos trazidos pelas águas das chuvas e rios, minimizando o assoreamento dos canais de navegação.

No entanto, em um levantamento realizado por Herz (1991), foi constado que mais de $10 \%$ dos Manguezais do Estado de São Paulo encontram-se alterados ou degradados. Silva et al (1994), corroboram a informação destacando, para os Manguezais da Baixada Santista, o registro de acentuadas alterações. Como exemplo cita o município de Cubatão onde restam apenas $17 \%$ da área de cobertura original de Manguezais $\left(29 \mathrm{Km}^{2}\right) \mathrm{em}$ bom estado de conservação. 
Constata-se que os agentes tensores que mais freqüentemente afetam os Manguezais são as atividades humanas, conforme destacado na Tabela 1.

Tabela 1. Impactos das atividades humanas sobre os Manguezais

\begin{tabular}{|c|c|}
\hline Atividade & Ações associadas \\
\hline $\begin{array}{l}\text { Extrativismo vegetal e } \\
\text { animal }\end{array}$ & $\begin{array}{l}\text { Desmatamento (retirada de madeira), coleta de frutos, caça e } \\
\text { pesca. }\end{array}$ \\
\hline Agricultura & $\begin{array}{l}\text { Inundações, canalizações, barramentos das águas (cultivo e } \\
\text { criação de peixes, camarões, ostras). }\end{array}$ \\
\hline Agricultura e pecuária & $\begin{array}{l}\text { Aterros, movimentação e exposição do solo em áreas próximas } \\
\text { do Manguezal, pisoteio do solo, uso de agrotóxicos. }\end{array}$ \\
\hline Portuária & $\begin{array}{l}\text { Desmatamento, aterros (expansão), lavagem e abastecimento } \\
\text { de navios, armazenamento e transporte de cargas tóxicas. }\end{array}$ \\
\hline Industrial & $\begin{array}{l}\text { Desmatamento e aterros (expansão), armazenamento, } \\
\text { processamento, transporte e descarga de materiais tóxicos. }\end{array}$ \\
\hline Imobiliária & $\begin{array}{l}\text { Desmatamento, construção de palafitas, residências, marinas } \\
\text { com canalizações, barragens, dragagens, aterros (expansão), } \\
\text { despejo de resíduos. }\end{array}$ \\
\hline Mineração & $\begin{array}{l}\text { Desmatamento, aterros, dragagens, alterações do leito e } \\
\text { margens dos rios, despejo de resíduos. }\end{array}$ \\
\hline Linhas elétricas & $\begin{array}{l}\text { Desmatamento, aterros (interceptação das áreas), descargas } \\
\text { elétricas acidentais, movimentação do solo no entorno }\end{array}$ \\
\hline Oleodutos/ gasodutos & $\begin{array}{l}\text { Desmatamento e aterros, interceptação do Manguezal } \\
\text { (vazamentos), movimentação do solo em áreas próximas. }\end{array}$ \\
\hline Rodovias e ferrovias & $\begin{array}{l}\text { Desmatamento (movimentação do solo), aterros (interceptação } \\
\text { da drenagem), canalizações, barramentos, acidentes com } \\
\text { cargas tóxicas, trânsito de veículos e acesso de caçadores. }\end{array}$ \\
\hline Aterros sanitários & Desmatamento, aterros para expansão, acúmulo de lixo. \\
\hline $\begin{array}{l}\text { Áreas de despejo e } \\
\text { empréstimo }\end{array}$ & Desmatamento, movimentação do solo, aterros, barramento. \\
\hline Salinas & $\begin{array}{l}\text { Desmatamento (expansão e lenha), canalizações e barramentos } \\
\text { (reservatórios para entrada e evaporação da água do mar). }\end{array}$ \\
\hline Barragens & $\begin{array}{l}\text { Desmatamento, inundações, interferências na dinâmica geral do } \\
\text { curso d'água e áreas adjacentes e movimentação de terra. }\end{array}$ \\
\hline
\end{tabular}

Fonte: Adaptado de Varjabedian (1995). 
No Estado de São Paulo, os sistemas estuarinos de Santos e São Vicente, na região da Baixada Santista, representam um dos maiores exemplos brasileiros de degradação ambiental por poluição de origem industrial em ambientes costeiros, destacando-se indústrias de base como siderúrgicas, petroquímicas e de fertilizantes, o que fez com que tais estuários se transformassem em grandes receptores de resíduos tóxicos e efluentes contaminados. Associado a tal fato, são também intensas as contribuições do Porto de Santos e municípios da região, com resíduos e esgotos. E, por fim, o quadro é ainda agravado pela disposição de resíduos sólidos industriais e domésticos em locais impróprios, além dos freqüentes acidentes com derramamento de óleo e outras substâncias tóxicas nos cursos d'água (CETESB, 2001a).

Neste contexto, os metais estão presentes como contaminantes na região. Mesmo com a importante redução da emissão de poluentes nos efluentes, devido à ação controladora da CETESB, a partir de 1984 (conforme apresentado na Tabela 2), continua alto o potencial de risco à saúde pública e equilíbrio dos ecossistemas costeiros regionais, em função da característica de acumulação que apresentam tais metais.

Tabela 2. Redução do lançamento de efluentes industriais nos corpos d’água de Cubatão

\begin{tabular}{lrrr}
\hline \multicolumn{1}{c}{ Poluentes } & $\begin{array}{c}1984 \\
\text { (ton/ano) }\end{array}$ & $\begin{array}{c}\text { 1994 } \\
\text { (ton/ano) }\end{array}$ & $\begin{array}{c}\text { Redução } \\
\text { (\%) }\end{array}$ \\
\hline Carga orgânica & 22.678 & 1.547 & 93 \\
Metais pesados & 1.467 & 44 & 97 \\
Fluoreto & 1.276 & 100 & 92 \\
Fenóis & 27 & 6 & 78 \\
Resíduos sedimentáveis & 216 & 22 & 90 \\
\hline
\end{tabular}

Fonte: CETESB (2001a). 
Assim, os metais podem ser um dos tensores responsáveis pela degradação de bosques de Manguezais, interferindo na regeneração das plantas nestas áreas. A análise deste parâmetro como indicador de qualidade ambiental e da sua ação sobre o sucesso reprodutivo, possibilita a identificação de situações críticas, para subsidiar ações de gerenciamento dos Manguezais.

A proposta deste estudo é, portanto, a avaliação da presença de metais na planta (propágulo, mudas e folhas de árvores adultas) e o efeito destes sobre o estabelecimento da Rhizophora mangle (Mangue vermelho), espécie de ampla distribuição nos Manguezais. Para tanto, foram selecionadas três áreas de estudo, localizadas em regiões degradadas de Cubatão e São Vicente, na Baixada Santista e uma quarta área, testemunha, na llha do Cardoso, Cananéia -SP.

\section{Hipótese}

A contaminação por metais interfere negativamente sobre 0 estabelecimento dos indivíduos de Rhizophora mangle nos Manguezais da Baixada Santista, sendo um dos indicadores da qualidade ambiental do Manguezal.

$\underline{\text { Objetivos }}$

Geral

Avaliar a situação de diferentes bosques de Manguezal por meio do estudo do estabelecimento de propágulos, mudas e indivíduos adultos de Rhizophora mangle em áreas submetidas à contaminação por metais. 


\section{Específicos}

- Identificar os agentes tensores atuantes sobre as áreas enfocadas.

- Quantificar a concentração de metais em propágulos e mudas da espécie estudada.

- Quantificar a concentração de metais em indivíduos adultos - árvores matrizes (folhas).

- Avaliar a interferência dos metais sobre o estabelecimento de Rhizophora mangle.

- Avaliar a qualidade ambiental de bosques de Manguezal sujeitos a diferentes agentes tensores, com base na situação de concentração de metais no meio (solo e água), nas plantas e em organismos. 


\section{REVISÃO DE LITERATURA}

\subsection{O Ecossistema Manguezal}

\subsubsection{Histórico}

No dicionário Oxford, mangrove deriva da palavra portuguesa Manguezal ou do espanhol Mangle, em associação com a palavra inglesa grove, "um conjunto de árvores" ou uma pequena floresta. No Grande dicionário da língua portuguesa, Manguezal é definido como: solos pantanosos à margem de lagoas e estuários; margens pantanosas de rios e portos; florestas ao longo de rios até o limite superior atingido pela água do mar (Vannucci, 1999).

Quanto à origem, as espécies típicas de Manguezais têm registros desde o Eoceno (Período Terciário), quando as angiospermas começaram a ocupar o ecótono entre e terra e o mar (Novelli \& Lacerda, 1994). Chapman (1975), descreve que houve uma evolução adaptativa das angiospermas a partir do final do Cretáceo e início do Eoceno, de tal forma que algumas espécies passaram a tolerar concentrações de sais no sedimento, sendo os gêneros Rhizophora e Avicennia considerados os primeiros a surgir (Coelho Jr., 1998), aparecendo a aproximadamente 60 milhões de anos (Novelli \& Lacerda, 1994). 
Chapman (1975) ressalta que o atual padrão de distribuição das espécies dos Manguezais é conseqüência da deriva continental, com os gêneros Rhizophora e Avicennia apresentando distribuição mais ampla (Coelho Jr., 1998). Novelli \& Lacerda (1994) acrescentam o aparecimento destas plantas em praticamente todas as latitudes onde ocorrem Manguezais.

Desde os tempos mais remotos, não somente os animais, mas também o homem, têm uma grande relação com o ecossistema Manguezal. Para inúmeras comunidades de pescadores tradicionais, este ecossistema desempenha um papel sócio-cultural importante para a subsistência, pois se utilizam diretamente dos recursos como a fauna como alimento e dos vegetais, utilizados para diversos fins (construção de moradia, utensílios de pesca, embarcações, acessórios, armadilhas, cercados, lenha, corante e medicamentos), além de outros usos (Vergara Filho et al., 1996).

No Brasil, tais relações entre o homem e os Manguezais foram comprovadas em estudos realizados em sambaquis ${ }^{1}$ (Menezes et al., 2000). Populações indígenas já se utilizavam destas áreas antes da chegada dos colonizadores europeus, como atestam os montes de ostras retirados das raízes de árvores do Manguezal (Schaeffer-Novelli, 2000).

No período colonial, além de fonte de alimento, o Manguezal era utilizado para retirada de madeira, lenha e tanino usado em curtumes. No século XVIII, a extração de madeira do Manguezal era tamanha que o Rei D. José, em Alvará com força de lei (1760), proíbe o corte de árvores que não tivessem tido sua casca previamente utilizada para tanino (Schaeffer-Novelli, 2000; Vannucci, 1999). Em 1812, o regente criou, no Rio de Janeiro, o laboratório químico prático e descobriu-se que a cinza mineral do Mangue, apresenta carbonato e cloreto de sódio, servindo a fabricação de sabão sólido.

\footnotetext{
${ }^{1}$ Sambaquis são depósitos de conchas, feitos em áreas litorâneas por antigas comunidades humanas.
} 
No entanto, é pertinente destacar, que as definições de Manguezal se transformaram ao longo do tempo à medida que as conceituações sobre seu valor e importância foram se estabelecendo. Historicamente, relatos sobre Manguezais feitos por diversos naturalistas e entidades governamentais, até a metade deste século, os apresentavam como áreas de pouca salubridade, sem utilidade para a agricultura e fonte potencial de doenças transmitidas pelos insetos que as habitam. Como conseqüência, a atitude frente a este ecossistema foi sempre drenar e aterrar para posterior uso (Lacerda, 1984).

A partir da década de 50, nas áreas estuarinas e de Manguezal começaram a ser implantadas indústrias e empreendimentos imobiliários, afetando não só o ambiente como as populações tradicionais que sobrevivem dos recursos do Manguezal (Schaeffer-Novelli, 2000). Atualmente é incontestável a importância ecológica destas áreas.

Ressalta-se que o Manguezal é considerado um recurso renovável, porém finito, quando se leva em conta a produção natural de peixes, ostras, caranguejos, camarões, siris, mariscos e até mel, além de proporcionar oportunidades recreativas, culturais, científicas e educacionais. Porém passa a ser considerado um recurso não renovável, quando são substituídos por outros usos do solo, ou ainda, por atividades que os transformam em depositários de efluentes, lixo e o extrativismo indiscriminado (Schaeffer-Novelli, 2000).

No caso específico da Baixada Santista, um dos primeiros trabalhos sobre Manguezais foi o de Luedwaldt, realizado em 1919, com levantamento da fauna e flora e descrição dos aspectos gerais da região de Santos e áreas adjacentes (Menezes, 1999).

Um pouco mais recentemente, no trabalho de Branco (1984), é descrita a história de Cubatão, desde os registros pré-históricos (sambaquis) até os tempos atuais. Para a época do Brasil Colônia, é destacado o potencial da região como zona de comércio e interligação entre o planalto e o Porto de Santos e, a fase da industrialização é subdividida em duas etapas: a primeira 
que empregou matéria-prima e mão-de-obra predominantemente local, não ultrapassando a capacidade suporte do ambiente, e a segunda, que utilizou energia proveniente da Usina Edgard de Souza e matéria-prima e mão-de-obra de outros Estados (Menezes, 1999).

\subsubsection{Mata Atlântica e o ecossistema associado Manguezal}

Os Manguezais brasileiros se estabelecem na faixa costeira leste, na região fitogeográfica da Mata Atlântica, que será descrita a seguir.

A vegetação litorânea do Brasil pertence, em sua maior parte, aos domínios da Floresta Pluvial Tropical Atlântica (Rizzini, 1979). Localizada na região dos trópicos, nas planícies ao longo da costa e escarpas das montanhas, esta floresta, também denominada de Mata Atlântica, inserida na Floresta Ombrófila Densa, é a segunda maior floresta neotropical ${ }^{2}$ do globo.

A mata está associada ao relevo e clima, especialmente à pluviosidade (médias anuais superiores a $2.000 \mathrm{~mm}$ ). O clima é descrito como variável de sub-úmido, com estações secas no nordeste, à extremamente úmida nas regiões da Serra do Mar, com temperatura média de 27, $7^{\circ} \mathrm{C}$ (Câmara, 1991).

A distribuição da Mata Atlântica se dá, então, como uma faixa que acompanha mais de $4.000 \mathrm{~km}$ na zona costeira de norte para sul, podendo ser compartimentada em três agrupamentos: Matas de planície litorânea, limitadas pelas serras, aparecendo logo após a faixa ocupada pela vegetação de dunas ou Manguezais; Matas de encosta, localizadas nas vertentes orientais das serras do sul e sudeste e Matas de altitude, que aparecem por volta de 1.100m. Inclui ainda ecossistemas associados costeiros, com influência direta do mar e ventos litorâneos, como as Restingas e os Manguezais (Cortesão et al., 1991).

\footnotetext{
${ }^{2} \mathrm{O}$ termo neotropical refere-se à localização no continente americano, sendo que a Floresta Amazônica é a primeira em tamanho entre as florestas pluviais do mundo. Juntas, a Floresta Amazônica e a Mata Atlântica colocam o Brasil como o país detentor da maior extensão de florestas neotropicais do globo.
} 
Esta vegetação litorânea apresenta grande variedade de formações vegetais condicionadas à natureza do substrato sobre o qual se desenvolve e assim, com base nesta correlação, dividiu o litoral brasileiro em três formações topográfico-edáfico-botânicas: litoral rochoso, arenoso e o lodoso. No primeiro, representado pelos maciços rochosos à beira-mar, os vegetais são restritos às plantas rupestres xerófitas que colonizam trechos onde há solo, mesmo escasso. Sobre o substrato arenoso ao longo da costa, têm-se formações vegetais variadas, com predomínio do estrato herbáceo até o arbustivo-arbóreo e, por fim, os Manguezais, característicos do substrato lodoso, apresentam solos com baixo teor de Oxigênio e alta salinidade, condições edáficas extremas que condicionam a fisionomia e composição florística, em especial o reduzido número de espécies da flora, altamente adaptada (Carvalhães, 1997).

Trata-se enfim de um dos ecossistemas mais diversos do mundo, chegando a ultrapassar 400 espécies por hectare. Segundo a Fundação SOS Mata Atlântica (1992), as elevadas taxas de endemismo na flora estão na ordem de 50\% para as 10.000 espécies de plantas conhecidas (com taxas endêmicas de $53 \%$ das espécies arbóreas, $74 \%$ das bromélias e $49 \%$ das palmeiras). Por (1992), destaca a grande riqueza em epífitas como um dos aspectos fisionômicos expressivos da Mata Atlântica colocando o o sudeste brasileiro como o maior centro de diversidade de bromélias, abundantes tanto na Floresta úmida quanto na Restinga e nos Manguezais.

Antagonicamente à sua riqueza e importância, a extensão original de cerca de 100 milhões de hectares, está sendo reduzida, chegando a menos de $10 \%$ da área primitiva ${ }^{3}$, com pequenos fragmentos remanescentes e poucas florestas extensas e conservadas (Fundação SOS Mata Atlântica, 1992).

\footnotetext{
${ }^{3}$ Vale ressaltar que não há consenso entre os diversos autores que tratam da definição da área de domínio da Mata Atlântica no território brasileiro. São verificadas pressões antagônicas nos diferentes setores da sociedade. A definição legal, atualmente em vigor, é a existente no Decreto Federal $n^{\circ} 750 / 93$, que inclui, na área de domínio da Mata Atlântica, as Florestas Ombrófilas Mistas e Abertas, Florestas Estacionais Semi-deciduais e Deciduais.
} 


\subsubsection{Caracterização dos Manguezais}

O ecossistema Manguezal é caracterizado por diferentes autores, sendo algumas conceituações compiladas nos parágrafos a seguir.

O Manguezal é uma cobertura vegetal representada por um grupo de espécies que possuem adaptações que lhes permitem colonizar terrenos alagados e sujeitos às intrusões salinas (Cintron \& Schaeffer-Novelli; 1985; Grasso et al., 1995). São geralmente sistemas jovens, pouco maduros, uma vez que a dinâmica das áreas onde se encontram produz constantemente modificações desses terrenos, resultando em uma seqüência de avanços e recuos (Coelho Jr., 1998; Schaeffer-Novelli, 1987).

É um ecossistema costeiro, de transição entre os ambientes terrestre e marinho, característico de regiões tropicais e subtropicais, sujeito ao regime das marés e constituído de espécies vegetais lenhosas típicas (angiospermas), além de micro e macroalgas (criptógamas) adaptadas à flutuação de salinidade, sedimentos predominantemente lodosos e com baixos teores de oxigênio (Schaeffer-Novelli, 1995).

Comunidade vegetal anfíbia, lenhosa e perenifólia, de vegetação sempre verde que se localiza às margens dos oceanos, crescendo sobre as costas planas nos terrenos de aluvião das desembocaduras dos rios, submetidas aos efeitos das águas mescladas do mar e rio ou às margens das lagoas (FEEMA, 1979).

Ecossistema aberto, sem limites precisos, dependente e interligado aos sistemas vizinhos através da exportação e importação de água, nutrientes e material sedimentar (Macedo, 1986). Trata-se de um ecossistema de alta produtividade por situar-se na faixa tropical com radiação solar intensa e porque recebe nutrientes e matéria orgânica das drenagens continentais e do oceano (Grasso et al., 1995). 


\subsubsection{Distribuição mundial e no Brasil}

O ecossistema Manguezal ocorre em uma variedade de condições ambientais, distribuindo-se mundialmente com importante contribuição das correntes marinhas no processo de dispersão dos propágulos, o que resulta em larga distribuição das espécies características deste ambiente (Walsh, 1974).

Sendo os Manguezais colonizadores de paisagens pantanosas, possuem em comum, mundialmente, muitas características florísticas e fisiológicas, mas mostram uma dinâmica e sensibilidade marcadas pelas influências ambientais específicas do local (Mastaller, 1990).

Destaca-se que há fatores limitantes que restringem e condicionam o aparecimento do Manguezal em certas regiões - aspectos discutidos a seguir.

\section{Condições ambientais ideais}

Todas as espécies do Manguezal são sensíveis ao frio, por isso a propagação destas, em ambos os hemisférios terrestres, é limitada pela temperatura de $16^{\circ} \mathrm{C}$ mínimos de isoterma d'água. Devido a temperatura da água, os Manguezais encontram-se principalmente na costa oeste dos continentes entre os $30^{\circ}$ de latitude norte e $30^{\circ}$ de latitude sul. A dependência por um abastecimento periódico de água doce explica a falta desta forma de vegetação nos litorais com clima desértico. Além disso, os Manguezais têm um desenvolvimento muito escasso nas regiões com ventos fortes que provocam ressecamento e desenraizamento (Mastaller, 1990).

Os padrões climáticos, em especial a pluviosidade, contribuem para condicionar as áreas passíveis de ocupação dos Manguezais, limitando-se àquelas com maiores aportes de água (rios, chuvas, marés) ou, às proximidades dos corpos de água cuja massa líquida atua controlando o excesso de sal ou ainda como tampão, quando da ocorrência de geadas (Novelli \& Lacerda, 1994). 
Mastaller (1990) aponta que os Manguezais ocorrem na sua maioria em estuários protegidos e lagoas rasas, usufruindo, nessa área aluvial, da troca regular de matéria orgânica, proporcionada pelas águas das marés e aportes de água doce pluvial e fluvial. Assim sendo, as condições ideais de temperatura e precipitação para o desenvolvimento dos Manguezais são:

- temperaturas médias acima de $20^{\circ} \mathrm{C}$;

- média das temperaturas mínimas não inferior a $15^{\circ} \mathrm{C}$;

- amplitude térmica anual menor que $5^{\circ} \mathrm{C}$;

- precipitação pluvial acima de 1.500 mm/ano, sem prolongados períodos de seca.

Segundo Walsh (1974), FEEMA (1979), Macedo \& Rocha (1985) e Ceará (1992), além da temperatura e precipitação, há ainda outras condições para o aparecimento dos Manguezais:

- solos aluviais onde predominam os lodos finos e ricos em matéria orgânica;

- áreas litorâneas planas e calmas, protegidas do impacto das ondas;

- larga amplitude da maré;

- existência de água salobra, formada pela mistura de água doce do rio com água salgada do mar.

Este ecossistema se desenvolveu, então, nas zonas litorâneas, em ambientes com intensa deposição onde a velocidade das correntes é reduzida, tal como fundos de baía, estuários e reentrâncias da costa (Leonel \& Simões, s/d). Macnae (1968), acrescenta que os bosques com estrutura mais desenvolvida estão nas áreas de maior freqüência de inundação e 
conseqüentemente, o menor desenvolvimento estrutural estaria associado às áreas com baixa freqüência de inundação e alta salinidade (Coelho Jr., 1998). Schaeffer-Novelli (1995) aponta que o desenvolvimento estrutural máximo dos Manguezais tende a ocorrer próximo à linha do Equador, ou ainda, segundo Cintron \& Schaeffer-Novelli (1985) e Grasso et al. (1995) na faixa compreendida pelos trópicos de Câncer e Capricórnio, onde devido à temperatura há maior desenvolvimento, e onde se tem, por exemplo, árvores de $R$. mangle nas regiões Paraenses com $25 \mathrm{~m}$ de altura e $32 \mathrm{~cm}$ de diâmetro, sendo que ao sul não atingem mais de $1,5 \mathrm{~m}$ de altura.

Flores-Verdugo et al. (1992) verificaram tal fato na laguna de Chalatilla, costa pacífica do México: os Manguezais são desenvolvidos, com baixa densidade e grande área basal; tendência de aparecimento de Manguezais exuberantes em baixas latitudes. Porém o desenvolvimento estrutural parece estar condicionado ao aporte de água doce e nutrientes terrígenos.

Por fim, Schaffer-Novelli (1995) acresenta que, embora o Manguezal seja um ecossistema tropical, também pode ocorrer em climas temperados, normalmente substituído por outros ecossistemas mais adequados às altas latitudes, tal como os Marismas. Assim sendo, a localização das áreas colonizadas por Manguezais são apresentadas a seguir.

\section{Distribuição mundial dos Manguezais}

Os Manguezais representam, segundo Grasso et al. (1995), cerca de $75 \%$ da vegetação entre-marés das áreas tropicais do globo. Macnae (1968) aponta um percentual de ocupação semelhante, entre 60 a 75\%.

Estima-se que os Manguezais do mundo cubram 17.100.000ha, e que destes, 7.000.000ha estejam limitados diretamente a lagoas rasas e deltas de rios (Mastaller, 1990). Os dados de Schaeffer-Novelli (1995) apontam para valores de extensão mundial de $162.000 \mathrm{Km}^{2}$ desse ecossistema. 
A principal região de ocorrência fica na Indonésia, cuja área estimada de Manguezais é de 4.200.000ha, extensão que representa cerca de $20 \%$ dos Manguezais do mundo (Choong et al., 1990). Esta grande concentração de Manguezais é justificada pela FAO (1994), descrevendo que o país é formado por 13.667 ilhas que somam $81.000 \mathrm{Km}$ de costa com condições propícias a colonização por Manguezal. Vannucci (1999) acrescenta que as florestas de Manguezal crescem até 35 ou 40m (algumas árvores atingindo 60m), e as florestas de Manguezal mais altas, composta de Rhizophora, ficam na Sumatra (Indonésia), e ainda que as árvores mais altas são encontradas em Esmeralda (Equador), representantes também de Rhizophoras.

Estimativas apresentadas por Ramos \& Silva (1996) apontam para o valor de 3.017.725,00 ha para a área de cobertura do ecossistema no litoral dos países da América Latina.

O Brasil situa-se entre os países com as maiores extensões de Manguezais do mundo (Ambiente Águas, 2002) sendo que as estimativas apresentadas por Ramos \& Silva (1996) apontam extensão de 1.376.255,00ha.

\section{Distribuição dos Manguezais no Brasil}

O Brasil possui uma orla litorânea de $7.408 \mathrm{Km}$ recortada por deltas, enseadas e baías onde o Manguezal está presente com maior ou menor intensidade (Lamberti, 1966). Ocorre, segundo Ambiente Águas (2002), Schaeffer-Novelli (1989 e 1995) e Grasso (1995) sob grande diversidade de condições ambientais, margeando estuários, lagunas e enseadas, desde o Amapá (Cabo Orange ou Rio Oiapoque - 04²0'N) até Santa Catarina (Laguna - 28³0'S), onde as massas oceânicas vindas do Equador têm seu limite de influência na temperatura das águas litorâneas, limitando australmente o ecossistema no Atlântico Sul. 
Pela sua distribuição costeira é considerado um ecossistema associado da Mata Atlântica. Apresenta-se mais desenvolvido em todo o litoral dos Estados do Amapá, Pará, incluindo parte da Ilha de Marajó, Maranhão e Piauí, além das extensas áreas na Baía de Todos os Santos-BA, Baía de Vitória-ES, Baías da Guanabara, Sepetiba e da Ilha Grande-RJ, nas regiões de Santos e Cananéia-SP, nas Baías de Paranaguá, Laranjeiras e de Guaratuba-PR, Baía de São Francisco e da Ilha de Santa Catarina e lagoas de Santo Antônio e do Imaruí - SC (Cunha-Lignon, 2001; Rodrigues et al., 1990).

Os Manguezais abrangem, no território brasileiro, uma superfície total de mais de $10.000 \mathrm{Km}^{2}$ segundo Ambiente Águas (2002), ou de cerca de $25.000 \mathrm{Km}^{2}$ (Schaeffer-Novelli, 1995), ou seja, variando de 10.000 a $25.000 \mathrm{Km}^{2}$ dependendo da fonte consultada.

Vannucci (1999) apresenta uma compilação dos dados apontados por Herz em 1991 e por Kjerfve \& Lacerda em 1993 sobre a área de cobertura de Manguezal nos estados brasileiros, associando-as à extensão da costa litorânea do estado. Estes dados são reproduzidos na Tabela 3 a seguir. 
Tabela 3. Distribuição dos Manguezais nos estados brasileiros

\begin{tabular}{|c|c|c|c|}
\hline Estado & $\begin{array}{c}\text { Extensão } \\
\text { litoral }(\mathrm{Km})\end{array}$ & $\begin{array}{l}\text { Área (ha) } \\
\text { Herz,1991 } \\
\end{array}$ & $\begin{array}{c}\text { Área (ha) } \\
\text { Kjerfve \& Lacerda,1993 }\end{array}$ \\
\hline \multicolumn{4}{|c|}{ Região Norte } \\
\hline Amapá & 598 & 162.270 & 182.300 \\
\hline Pará & 582 & 181.972 & 389.400 \\
\hline \multicolumn{4}{|c|}{ Região Nordeste } \\
\hline Maranhão & 640 & 492.310 & 500.000 \\
\hline Piauí & 66 & 6.233 & 43.770 \\
\hline Ceará & 573 & 11.011 & 22.940 \\
\hline Rio Gde do Norte & 399 & 14.181 & 6.990 \\
\hline Paraíba & 117 & 7.397 & 10.080 \\
\hline Pernambuco & 228 & 6.555 & 7.810 \\
\hline Alagoas & 229 & 5.685 & 3.565 \\
\hline Sergipe & 163 & 16.772 & 26.200 \\
\hline Bahia & 932 & 44.537 & 110.000 \\
\hline \multicolumn{4}{|c|}{ Região Sudeste } \\
\hline Espírito Santo & 392 & 8.951 & 19.500 \\
\hline Rio de Janeiro & 636 & 8.994 & 16.000 \\
\hline São Paulo & 622 & 13.994 & 23.100 \\
\hline \multicolumn{4}{|c|}{ Região Sul } \\
\hline Paraná & 98 & 20.825 & 51.000 \\
\hline Santa Catarina & 531 & 8.313 & 3.000 \\
\hline TOTAL & 6.806 & 1.010 .000 & 1.376 .255 \\
\hline
\end{tabular}

Fonte: Adaptado de Vannucci (1999).

As considerações que Vannucci tece a respeito de tais dados ilustram a distribuição dos Manguezais no Brasil e a grande diversidade de condições em que o ecossistema se encontra, conforme pode ser constatado nos parágrafos da seqüência. 
Cerca de $85 \%$ dos Manguezais brasileiros ocorrem ao longo de $1.800 \mathrm{Km}$ do litoral norte, nos estados do Amapá, Pará e Maranhão. Nesta região, Avicennia é o gênero mais freqüente podendo atingir $1 \mathrm{~m}$ de diâmetro e 40m de altura; Rhizophora ocorre próximo à linha da costa enquanto a franja junto ao mar é dominada por Spartina e a franja terrestre por Hibiscus tiliaceus. Os Manguezais do norte são os maiores e estruturalmente mais complexos do país, refletindo as características hidrológicas e topográficas, com marés semidiurnas de amplitude de mais de $8 \mathrm{~m}$ em alguns locais, inundando grandes áreas do litoral constituído por extensas planícies quaternárias, com contribuição também das águas abundantes da estação chuvosa (excede 2000 $\mathrm{mm} / \mathrm{ano}$ ). Na região os Manguezais podem se estender a mais de $40 \mathrm{~km}$ terra adentro, seguindo o curso de rios e estuários.

O litoral nordeste, do Ceará ao Rio de Janeiro, embora englobe quase metade do litoral brasileiro possui apenas cerca de $10 \%$ da área total de Manguezais do país. Esse litoral é caracterizado por micro e mesomares e estreitas planícies costeiras, pela presença da Formação Barreiras que se estende até o litoral limitando a extensão dos Manguezais e por um clima geralmente semi-árido, com precipitação restrita a poucos meses do ano até o litoral da Bahia, onde se torna úmido em direção ao sul, permitindo desenvolvimento de extensos Manguezais no interior de baías e na foz dos principais rios da região. Os Manguezais nordestinos são mais baixos e estruturalmente menos complexos que os do litoral norte, sendo a $R$. mangle, a espécie mais conspícua, atingindo 10-20m de altura.

O litoral sudeste, do Rio de Janeiro à Santa Catarina, possui cerca de $1.250 \mathrm{~km}$ e inclui somente $5 \%$ da área total de Manguezais no Brasil, sendo região dominada pela Serra do Mar, que limita em extensão as planícies costeiras, de forma que os Manguezais são restritos ao interior de baías, embora em várias áreas sejam mais desenvolvidos e complexos que os do litoral nordeste. As florestas são constituídas por árvores baixas, raramente 
ultrapassando 10m de altura, e tipicamente não apresentam uma dominância de espécies. Ambiente e Águas (2002) aponta, para o Estado de São Paulo, mais de $240 \mathrm{Km}^{2}$ de áreas cobertas com Manguezais.

Os Manguezais brasileiros apresentam, então, grande variabilidade quanto à distribuição, extensão e desenvolvimento estrutural, fatores que estão na dependência da amplitude das marés, salinidade, clima e substrato, o que proporciona não apenas diferenças estruturais entre as florestas (SchaefferNovelli, 1995) como também nos variados tipos de pressões atuantes sobre tais áreas (Carmo et al., 1998b; Jimenez, 1985).

Essa variabilidade deve ser levada em conta na elaboração das propostas voltadas ao manejo, uma vez que cada Manguezal exige estratégias peculiares para sua manutenção (Schaeffer-Novelli, 1989; Carmo et al., 1998a) em função dos diversos tensores ambientais, em especial o desenvolvimento desordenado das áreas costeiras brasileiras (Grasso, 1995). Sobre os Manguezais das regiões Norte e Nordeste primam o empirismo e o imediatismo na apropriação dos recursos naturais (como derrubada de árvores para lenha, construções e extração de tanino; pesca predatória de moluscos, crustáceos e peixes, atividades salinieras e instalação de viveiros e tanques de aqüicultura). No litoral do Sudeste e Sul, o extrativismo continua imperando sobre os sistemas costeiros, porém mais danosos são os aterros, lixões, empreendimentos imobiliários, efluentes industriais, que são inatalados nos espaços dos Manguezais por serem considerados terra de baixo custo, sendo ignorado o real valor e funções sociais (Schaeffer-Novelli, 2000). 


\subsubsection{Sistemas de classificação}

Lugo \& Snedaker citados por Coelho Jr. (1998), desenvolveram uma classificação dos bosques de Manguezal com base nas características fisiográficas, associando a estas a assinatura energética. Reconheceram seis tipos fisiográficos de bosques: Ilhote, Ribeirinho, Franja, Bacia, Arbustivo e Anão. Cintrón et al. e Cintrón \& Schaeffer-Novelli citados pelo mesmo autor, reagruparam estes tipos, considerando apenas: Bosques Ribeirinhos, Bosques de Franja e Ilhote e Bosques de Bacia e os tipos Anão e Arbustivo são tratados como casos especiais. Assim, estes são descritos:

- Bosques Ribeirinhos: desenvolvem-se às margens dos rios onde o fluxo intenso de água traz nutrientes; apresentam bosques mais desenvolvidos; $R$. mangle é a espécie mais favorecida pelas suas adaptações específicas.

- Bosques de Franja e Ilhote: desenvolvem-se ao longo das margens de costas protegidas; estão submetidos a flutuações diárias das marés (o que minimiza a formação de fortes gradientes físico-químicos); apresentam características estruturais dependentes da quantidade de nutrientes das águas e da energia cinética; em geral são monoespecíficos ou colonizados nas bordas por $R$. mangle e no interior por Avicennia sp.

- Bosques de Bacia: estabelecem-se nas partes mais internas, atrás dos Ribeirinhos ou de Franja, e por isto tem a renovação da água de forma mais lenta e fluxos regulares (que originam maior regularidade nas condições físicas e químicas do sedimento), levando a uma seleção de espécies que com zonação definida. O grau de desenvolvimento depende da magnitude da drenagem e da freqüência de inundação. A. schaueriana e L. racemosa são mais comuns devido às adaptações a salinidade mais alta e menores freqüências de inundação. O bosque pode ser monoespecífico, enquanto que $R$. mangle é encontrada geralmente nas proximidades de canais ou depressões mais acentuadas. 
Mastaller (1990) cita uma classificação e caracterização um pouco diferente, porém contendo cinco tipos de Manguezal: Bosque de Franja, Bosque de Bacia, Bosque Ribeirinho, Bosque Inundado e Bosque Anão.

- Bosque de Franja; forma típica de vegetação das costas baixas, geralmente matas de ilhas; cobertas e inundadas pelas marés; alta deposição de matéria orgânica e sedimentos finos devido a correntes hídricas pouco intensas; casualmente alta salinidade (de 35 a 60\%).

- Bosque de Bacia; localizados nas depressões da costa freqüentemente em direção ao interior, ao lado das redes de esgotos terrestres e nos centros de ilhas; alto grau de concentração de matéria orgânica e poucos sedimentos redutíveis; salinidade superior a 50\%.

- Bosque Ribeirinho; localizados nas planícies inundadas dos deltas fluviais; longos períodos de inundação especialmente depois das chuvas fortes; salinidade entre 5 e $20 \%$.

- Bosque Inundado; aparece ao longo de lagoas e ilhas pequenas, em locais geralmente inundados completamente durante os ciclos de maré, com intensa lavagem de matéria orgânica; salinidade entre 5 e 35\%.

- Bosque Anão: forma típica de vegetação nos solos calcários e nas zonas áridas com arbustos esparsos; alta salinidade superior a $60 \%$.

Schaeffer-Novelli (1989) retoma o tema da classificação fitofisionômica dos Manguezais e apresenta uma divisão do litoral brasileiro em sete unidades fisiográficas, associando suas feições (relevo, tipo de solo, cobertura vegetal) às temperaturas médias anuais, evapotranspiração potencial, amplitude das marés médias e de sizígia, forças estas que atuam diretamente sobre 0 ecossistema condicionando suas características estruturais e funcionais. 


\subsubsection{Diversidade}

O Manguezal é composto por plantas lenhosas, comumente chamadas de Mangue, algumas espécies herbáceas, epífitas, hemiparasitas, aquáticas típicas, macro e microalgas e liquens (Schaeffer-Novelli, 1995).

O número de espécies que compõe a vegetação do ecossistema Manguezal é considerado reduzido. Ao contrário de outras florestas, estes não são muito ricos em espécies vegetais, porém se destacam pelo grande número de indivíduos/espécie, ou seja, pela abundância das populações que neles vivem (Ambiente e Águas, 2002; Lacerda, 1984).

Lamberti (1966) cita que as "espécies obrigatórias" vivem estritamente no âmbito da ação das marés e sobre solo mais lodoso do que arenoso (diâmetro de partículas variando de 0,002 a 0,02mm, que na escala Atterberg correspondem a argila e limo) e as "espécies facultativas" ou "marginais" são ocasionalmente atingidas pelas marés de grande amplitude e habitam sobre solo cuja composição granulométrica apresenta maior porcentagem de limo e areia fina (diâmetros entre 0,02 e 0,2mm).

Diversidade nos Manguezais do globo

De acordo com Mastaller (1990), ocorrem cerca de 60 espécies de árvores e arbustos que figuram nos bosques de Manguezal espalhados mundialmente, sendo que cerca de 20 ocorrem também em outras formações. A região do sudoeste do Atlântico (com 14 espécies) é mais pobre em espécies que a região do sudeste da Ásia (com 58 espécies). 
Diversidade nos Manguezais brasileiros e da região sudeste

A formação vegetal dos Manguezais brasileiros, no que se refere à plantas arbóreas, é constituída basicamente por três gêneros (Rhizophora, Avicennia e Laguncularia) e seis espécies ( $R$. mangle, $R$. racemosa, $R$. harisonii, A. schaueriana, A. germinans e L. racemosa), com três destas apresentando ampla distribuição: o Mangue vermelho ( $R$. mangle), o Mangue branco ( $L$. racemosa) e o Mangue siriúba ( $A$. schaueriana). Figuram ainda no Manguezal elementos não típicos como o Conocarpus erecta, Hibiscus tiliaceus e a samambaia Acrosticum aureum (característicos de áreas de transição para o ambiente terrestre). O Manguezal é rico em espécies de algas e líquens, segundo Coelho Jr. (1998); Lacerda (1984) e Schaeffer-Novelli (1989).

Na região sudeste brasileira são encontradas quatro destas espécies: R. mangle, A. schaueriana, A. germinans e L. racemosa. Mais especificamente no litoral paulista, onde se insere a Baixada Santista, cita-se o exemplo da flora do Manguezal da Estação Ecológica Juréia-Itatins, típica deste litoral, e onde figuram apenas três: $R$. mangle, $L$. racemosa e $A$. schaueriana, sendo a última bastante mais rara. Os arbustos de $H$. tiliaceus, a samambaia $A$. aureum e há Spartina brasiliensis no estrato herbário.

A presença da Spartina tem sido citada por diversos autores, dentre os quais Leonel \& Simões (s/d), que descrevem que a gramínea coloniza a região frontal dos bosques de Manguezal, como a primeira a ocupar os bancos arenoargilosos onde os processos de sedimentação estão se iniciando, possibilitando assim, o acúmulo de lodo que favorece a colonização pelas espécies arbóreas (FEEMA, 1979). Desta forma, conforme citado por Moura et al. (1998), a planta é classificada como uma espécie pioneira dos marismas na costa Atlântica e considerada muito importante pois não sofre competição com nenhuma outra espécie de água salgada, serve à manutenção da morfologia de margens e é precursora de áreas de Manguezal, sendo seu uso sugerido em processos de recuperação de Manguezais degradados. 
Caracterização das espécies presentes nos Manguezais da Baixada Santista

Lamberti (1966), Novelli \& Lacerda (1994) e Schaeffer-Novelli (1995) descrevem características das pricipais plantas do Manguezal na região:

- Rhizophora mangle Linn.

Sinonímia: Rhizophora americana Nutt., R. racemosa GFW.

Família: Rhizophoreae.

Nomes vulgares: Mangue, Mangue vermelho, Mangue verdadeiro, Mangue sapateiro, Mangue de pendão, Mangue preto, Quaparaíba, Apareíba, etc.

Hábito: Arbóreo (árvores com 6m ou mais, muito ramificadas).

Florescimento: dezembro e janeiro.

Ocorrência: Litoral da América tropical, oriental e ocidental (no litoral brasileiro até Santa Catarina), Antilhas, México, Flórida, África ocidental.

É em geral encontrada nas franjas dos bosques. As plantas desse gênero toleram salinidades de até 55 ppm, porém crescem melhor quando esses valores se aproximam ou são menores que 35 ppm (salinidade da água do mar). A característica peculiar do gênero é o sistema de sustentação, com raízes-escoras (rizóforos) que partem do tronco, e as raízes adventícias que partem dos galhos. Os frutos germinam ainda presos à árvore-mãe e dão origem a propágulos em forma de lança, cuja viabilidade pode chegar a 12 meses (Novelli \& Lacerda, 1994). 
- Avicennia schaueriana Stapf \& Leechman

Sinonímia: A. tomentosa Jacq. ; A. nitida Jacq. var. trinotensis Moldenke.

Família: Verbenaceae.

Nomes vulgares: Siriba, Siriúba, Mangue branco, amarelo ou preto.

Hábito: Arbóreo (árvore com até 10m ou mais ramificações caulinares finas).

Florescimento: fevereiro e março.

Ocorrência: Litoral da América tropical, oriental e ocidental, México, Flórida.

Ocupa terrenos da zona entremarés. Essas plantas toleram salinidades intersticiais muito mais altas que os demais gêneros de Manguezal, chegando a sobreviver em locais com 90 ppm. Os propágulos permanecem viáveis por cerca de 3 meses (Novelli \& Lacerda, 1994).

O sistema radicular é muito ramificado horizontalmente com ramos com mais de $5 \mathrm{~m}$ de comprimento e profundidade não superior a $0,5 \mathrm{~m}$. Dos ramos nascem, em grande número, raízes geotropicamente negativas, de configuração cônica; os pneumatóforos, normalmente apresentam $20-30 \mathrm{~cm}$ de altura. Essas raízes aéreas são de consistência esponjosa e providas de pequenas lenticelas chamadas pneumatódios. O tecido cortical é provido de um grande número de espaços intercelulares responsáveis não só pelo armazenamento de grande quantidade de ar como também pela consistência esponjosa do órgão. 
- Laguncularia racemosa Gaertn

Sinonímia: Conocarpus racemosa Linn. Et Jacq., Bucida buceras Vell., Schousboa commuttata Spreng., Laguncularia glabriflora Presl.

Família Combretaceae.

Nomes vulgares: Mangue branco, Mangue manso, Tinteira, Mangue rasteiro, Canapomba, Canapaúba, Siriba, Cereiba, etc.

Hábito: Arbóreo (árvores pequenas, com 4-6m de altura).

Florescimento: janeiro e fevereiro.

Ocorrência: América tropical (litoral oriental e ocidental). África tropical ocidental.

O sistema radicular é pouco profundo (não ultrapassa $30 \mathrm{~cm}$ ) e apresenta pneumatóforos (menores e em menor quantidade do que Avicennia), indivisos, bi ou trifurcados. Habita costas banhadas por águas de baixa salinidade, não tolera locais com amplas flutuações no nível das preamares. Os propágulos são viáveis por cerca de 30 dias (Novelli \& Lacerda, 1994).

- Hibiscus tiliaceus L.

Família: Malvaceae

Nomes vulgares: Hibisco, Algodão da praia

Hábito: Arbustivo (com 3-5m de altura; é comum ramificar-se muito a curta distância do solo).

Florescimento: ao longo de todo ano.

Ocorrência: espécie pantropical das ilhas do Pacífico, regiões tropicais e subtropicais do mundo; comum na arborização urbana; algumas vezes é invasora. Apresenta folhas e flores grandes e raízes adventícias bastante ramificadas, finas e de pouca penetração no solo. 
- Acrostichum aureum L.

Família: Polypodiaceae.

Nome vulgar: Avencão, Samambaia do mangue

Hábito: Herbáceo (1,0m de altura).

Ocorrência: regiões tropicais e sub-tropicais.

Erva terrestre com folhas compostas em forma de penas e sistema radicular superficial, constituído por raízes adventícias.

- Spartina brasiliensis

Família: Poaceae

Nome vulgar: Espartina

Hábito: Herbáceo

Ocorrência: cosmopolita

\subsubsection{Zonação}

Definição

Forma de colonização do espaço em zonas, camadas ou faixas distintas, compostas por apenas uma espécie ou por um dado conjunto de espécies arbóreas (Coelho Jr., 1998), sendo estas distribuídas espacialmente em relação à linha d'água (Schaeffer-Novelli, 1995). 


\section{Fatores condicionantes}

De acordo com Ceará (1992), a zonação do Manguezal é decorrente das exigências da espécie quanto à imersão, salinidade e solo e, em função de tais fatores podem ocorrer modificações na ordem de ocorrência das espécies.

O padrão de zonação, segundo Novelli \& Lacerda (1994), é controlado em grande medida pela competição interespecífica e seleção dos propágulos pelas marés. Uma vez atingido o equilíbrio sucessional em cada zona do bosque, modificações só ocorrerão sob perturbações externas naturais (raios, furações, variação do nível médio do mar) ou induzidas (barragens, aterros, diques, drenagens), onde o sistema volta ao estágio sucessional anterior.

Watson (1928) ao estudar os Manguezais na Península Malaia, definiu zonas como áreas específicas influenciadas por uma combinação de freqüências e classes de inundações pelas marés, destacando o padrão de inundação como fator primário na distribuição das espécies do Manguezal.

Para Leonel \& Lacerda (s.d.) a zonação das espécies dominantes nos Manguezais brasileiros estaria relacionada com a salinidade, fato este partilhado por Coelho Jr. (1998), que descreve, para as regiões de clima seco ou com estações bem definidas, uma clara zonação das espécies vegetais com Rhizophora nos canais (em sedimentos com salinidade até 65\%) e Avicennia e Laguncularia dominando em sedimentos com salinidade entre 65 e 100\%. Trabalhos como o de Soto \& Jiménez (1982) têm demonstrado a estreita relação da distribuição das espécies de Manguezal com o gradiente salino no solo.

No entanto, não há consenso entre autores na definição do fator de importância preponderante na zonação. Adams (1963) considerou que a flutuação da maré; Tomlinson (1986) ressalta a composição do substrato na determinação da distribuição das espécies de Manguezal, além de outros fatores como o pH e o teor de matéria orgânica, têm sido apontados como contribuintes da zonação. 
Segundo Cunha-Lignon (2001) e Jimenez (1985) a dominância relativa das espécies e zonação no Manguezal são influenciadas pela topografia, geomorfologia, hidrologia e sedimentologia de cada sistema, sendo que as pequenas irregularidades da topografia poderiam afetar a superfície das feições de sedimentação e os processos erosivos e deposicionais da região. Tal consideração é compartilhada por Coelho Jr. (1998) que afirma que o padrão de zonação está relacionado às modificações impostas pela microtopografia e freqüência de inundação, resultando em gradientes físico-químicos, sendo os processos de sucessão e zonação das espécies, respostas a este gradiente.

Padrão de zonação nos Manguezais brasileiros

As constatações de diversos autores ressaltam que um dos principais aspectos determinantes da tipologia dos bosques de Manguezal é a ação das marés condicionando a possibilidade de colonização do espaço, predominância de espécies e estrutura do bosque, uma vez que as marés são o principal mecanismo de penetração das águas salinas nos Manguezais, tornando o substrato favorável à colonização pela vegetação (Schaeffer-Novelli, 1995).

Para os Manguezais brasileiros, os trabalhos realizados por Ceará (1992) e Macedo (1986) destacam um zoneamento onde o primeiro ocupante seria a gramínea Spartina cujas hastes favorecem o acúmulo de lodo, possibilitando a ocupação da Rhizophora, que fixaria ainda mais os sedimentos através do emaranhado de raízes, e logo após, instalam-se a Avicennia e Laguncularia, nos locais mais internos e tranqüilos, de solo mais firme, além do Hybiscus e Acrostichum nas faixas de transição entre o Manguezal e os sistemas de terra firme, ou ainda em Manguezais alterados. 
O tamanho e o peso dos propágulos são importantes fatores na zonação dos bosques de Manguezal. Rhizophora ocupa as zonas mais próximas do mar onde as inundações são mais freqüentes, devido ao peso dos seus propágulos que oferecem maior resistência às perturbações da maré. Os pequenos propágulos de Avicennia flutuam e necessitam de um período livre dos distúrbios ocasionados pela maré para se fixarem ao substrato, ocorrendo, deste modo, em locais mais afastados do mar onde a freqüência de inundações é menor. Os propágulos de Laguncularia, também pequenos mas com menor poder de flutuação, afundam e também necessitam de um período livre de perturbações da maré para se fixar, ocupando as áreas mais afastadas do mar (FEEMA, 1979; Rabinowitz, 1978a).

No Manguezal do Rio da Passagem, R. mangle foi dominante nos sedimentos do tipo areia lamosa, ricos em matéria orgânica. O aumento da densidade relativa de $L$. racemosa, observado na região limítrofe ao ambiente terrestre, está relacionado principalmente ao tipo de sedimento arenoso. $A$. schaueriana esteve presente próxima à margem do corpo d'água, enquanto que C. erectus ocorreu apenas na zona de transição entre o ambiente terrestre e aquático, ou seja, no ecótono (Carmo et al., 1998).

A ordem de ocorrência das espécies na zonação varia tanto do Novo para o Velho Mundo como dentro de áreas geograficamente próximas. Coelho Jr. (1998) e Schaeffer-Novelli (1995) ressaltam uma variabilidade na composição específica e no acúmulo de biomassa caracterizadas pelo desenvolvimento estrutural, demonstrando a maleabilidade das espécies e potencialidade de acomodação sob diferenças ambientais. Assim, autores que estudaram os Manguezais da costa brasileira concluiram que a zonação, apesar de comum, não não é bem definida ou obrigatoriamente encontrada, sendo variável sob peculiaridades ambientais locais. 


\subsubsection{Estrutura dos bosques}

A caracterização estrutural da vegetação dos Manguezais constitui ferramenta no que concerne à resposta desse ecossistema às condições ambientais bem como aos processos de alteração do ambiente (Soares, 1999).

A variabilidade estrutural dos bosques de Manguezal e a predominância de cada um em determinado ambiente está relacionada, em primeiro lugar, às características do substrato. A energia dos aportes fluviais e marinho aliada às marés e aos processos de assoreamento e/ou erosão, agem em conjunto sobre uma região determinando as feições da paisagem.

A fisionomia da comunidade vegetal do Manguezal reflete a densidade, o porte e a distribuição das árvores das diversas espécies que a compõe. Esse conjunto de características interdependentes determina a estrutura do bosque, que corresponde ao grau de desenvolvimento do ecossistema. A estrutura do bosque varia ao longo do tempo determinando vários graus de maturidade. Os bosques jovens caracterizam-se por apresentar alta densidade de troncos de diâmetro reduzido, já os bosques maduros caracterizam-se por apresentar uma baixa densidade de troncos, porém de diâmetro elevado (CETESB, 1989).

Assim, a estrutura dos bosques de Manguezal é reflexo de sua maturidade ou idade. Durante o desenvolvimento do bosque ocorrem trocas que alteram a fisionomia. O processo de desenvolvimento pode ser descrito segundo o modelo proposto por Jimenez (1985):

- Período de colonização: a taxa de ocupação do substrato é função da disponibilidade de propágulos menos as perdas provocadas pela mortandade e dispersão. As perdas por esta última causa são por sua vez modificadas pelo grau de exposição a ondas ou correntes.

- Período de desenvolvimento: fase que se caracteriza pela forte competição por espaço e pela mortandade das árvores menos aptas. O bosque apresenta seu maior desenvolvimento, principalmente em altura. 
- Período de maturidade: A taxa de crescimento se reduz durante este período e a mortandade se limita às árvores que perderam a competição ou por recrutamento tardio. O bosque apresenta seu maior desenvolvimento, principalmente em termos de altura.

- Senescência: etapa alcançada quando os bosques diminuem sua densidade. A morte das árvores abre clareiras no dossel, permitindo a entrada de luz com conseqüente benefício aos indivíduos novos.

Os bosques de Manguezal podem apresentar diferenças importantes em sua estrutura e funcionamento de acordo com a região, obedecendo a um grande número de fatores e processos ambientais (Cunha-Lignon, 2001).

Estrutura e produtividade dos bosques de Manguezal estão regulados pela salinidade da água intersticial, taxa de Oxigênio disponível às raízes e concentração de nutrientes (Hutchings \& Saenger, 1987). Esses fatores seriam controlados principalmente pela freqüência de inundação (marés), taxa de evaporação e aporte de água doce pluvial e fluvial (Coelho Jr., 1998).

Dassie (1997) cita que a densidade das espécies de um Manguezal não impactado na região próxima ao Rio Caiubura (Bertioga) é de 3.700 ind/ha com DAP médio de $7,5 \mathrm{~cm}$ e altura média de $7,7 \mathrm{~m}$. Nessa região predomina a $L$. racemosa (49,9\%), depois $A$. shaueriana $(37,7 \%)$ e por fim a $R$. mangle $(12,8 \%)$. O mesmo autor op cit encontrou em uma área em regeneração, uma densidade de 9.630 indivíduos/ha, sendo $77,5 \%$ de $A$. schaueriana, 13,1\% de L. racemosa e $9,3 \%$ de $R$. mangle, com DAP médio de $2,5 \mathrm{~cm}$ e altura média de $3,1 \mathrm{~m}$. As diferenças sugerem que a sucessão não se daria pela ocorrência de novas espécies (são sempre as mesmas), mas pela variação nos percentuais de ocorrência. A maior dominância de $L$. racemosa na área em regeneração evidenciaria seu papel de pioneira. 
Estas características vão ao encontro da teoria de mosaico de manchas (Soares, 1999), onde a heterogeneidade estrutural é forte indicadora de área alterada. Para bosques em recomposição, valores reduzidos de diâmetro e altura médios, como resultado de intervenções humanas recorrentes, foram encontrados por Jimenez (1985).

A diversidade estrutural pode ser um exemplo do mencionado por Lugo (1998) que afirma que distúrbios em Manguezais "estáveis" permitem a colonização por diversas espécies mas com o tempo a diversidade é reduzida pela seleção ambiental, retornando a um bosque monoespecífico. Smith III (1992), corrobora tal fato acrescentando que Manguezais sujeitos a maior freqüência de distúrbios possuem maior número de espécies vegetais.

\subsubsection{Solo}

\section{$\underline{\text { Características }}$}

Os Manguezais geralmente se desenvolvem em áreas geomorfologicamente ativas que recebem grandes quantidades de sedimentos. Podem ser consideradas como formações colonizadoras oportunistas, que seguem os processos da sedimentação ao invés de antecedê-los (Novelli \& Lacerda, 1994). O ambiente é dinâmico; assim a vegetação está constantemente respondendo e se ajustando aos processos geomorfológicos e o relevo é continuamente retrabalhado e remodelado por forças externas.

Sob tal situação ambiental, os solos do Manguezal são formados por sedimentos que possuem características variáveis devido às diferentes origens. Podem ser originados no próprio ambiente, formados a partir dos produtos de decomposição de rochas de diferentes naturezas, associados a materiais vulcânicos, graníticos, gnáissicos ou sedimentares e a restos de plantas e de animais, além da própria cobertura vegetal que pode modificar as características do substrato devido à contribuição em matéria orgânica. No 
geral, estes solos têm muita matéria orgânica, alto conteúdo de sal, baixa consistência, cor cinza escuro, com exceção dos embasamentos de recifes de coral e ambientes dominados por areias (Schaeffer-Novelli, 1995).

Os Manguezais compõe um sistema especial, com solos pouco conhecidos, que recebem a denominação de "solos indiscriminados de mangue". Na definição da EMBRAPA (1978), estes são solos halomórficos desenvolvidos a partir de sedimentos marinhos e fluviais com presença de matéria orgânica, de ocorrência em regiões de topografia plana, na faixa costeira sob a influência constante do mar. Dentre as variações destes solos estão os tipos Gley Húmicos, Gley Pouco Húmicos e os Solos Orgânicos.

Os solos dos Manguezais em geral apresentam granulometria caracteristicamente fina, com dominância fundamental das frações de tamanho menor que 0,05 mm, ou seja, silte-argila. Schaeffer-Novelli (1989) afirma que nas áreas caracterizadas por maior energia, o sedimento tende a ser composto por fração mais grosseira e nas áreas com menor energia das marés, há um favorecimento à deposição de finos. Lugo (1998) acrescenta que a pequena amplitude das marés e o emaranhado de rizóforos e pneumatóforos facilitam a deposição dos sedimentos finos até o interior do bosque. Na situação em que os Manguezais se estabelecem as taxas de acumulação de sedimentos é alta, da ordem de 0,1 a 0,2cm.ano-1, segundo Smoak \& Patchineelam (1999).

Assim estes solos são bastante variáveis na composição mineralógica e outros parâmetros como o $\mathrm{pH}^{4}, \mathrm{CTC}^{5}$, teor de matéria orgânica, capacidade de retenção de água, potencial redox, salinidade, Nitrogênio e Fósforo extraível (Cardona \& Botero, 1998). Marius \& Lucas (1991) afirmam que as principais propriedades dos solos de Manguezal são salinidade (influência marinha) e elevada acidez (devido ao elevado conteúdo de Enxofre de origem marinha).

\footnotetext{
${ }^{4} \mathrm{pH}$ - Potencial Hidrogeniônico - valor que expressa a acidez.

${ }^{5}$ CTC - Capacidade de troca catiônica.
} 
Vannucci (1999), descreve que a maioria dos materiais depositados no Manguezal fica compactado e, com isso, resta pouco espaço intersticial e os sedimentos se tornam gradualmente deficientes em Oxigênio ou mesmo totalmente anóxicos ${ }^{6}$; Schaeffer-Novelli (1995), confirma que a deficiência de Oxigênio e abundância de Sulfeto de Hidrogênio $\left(\mathrm{H}_{2} \mathrm{~S}\right)$ seria função das grandes quantidades de matéria orgânica, água e sais existentes nos Manguezais, e que em contato com o ar, pode resultar em condições extremamente ácidas.

É importante destacar que o sedimento atua como acumulador de vários elementos, incluindo macronutrientes como Nitrogênio e Fósforo, além de metais e tanto a liberação, como a mobilização desses elementos dependem da disponibilidade de Oxigênio, $\mathrm{pH}$, comunidade de algas e de bactérias, ação das marés, aporte de água doce e da própria natureza do sedimento (Novelli \& Lacerda, 1994) e também pela presença de cobertura vegetal (Chiu \& Chou, 1991; Tam et al., 1995).

Os elementos traço nos solos do Manguezal são de orígem natural e antrópica. Os primeiros aparecem especialmente como componentes traço de minerais dendríticos e os antrópicos são carregados pelas águas superficiais se associando ao material particulado em complexos argilo-metálico-orgânicos ou são transportados na forma dissolvida ou como colóides (hidróxidos).

\footnotetext{
${ }^{6} \mathrm{~A}$ Pirita é formada em ambientes redutores com presença de matéria orgânica, $\mathrm{Fe}^{3+}$ e atividade de microrganismos. As bactérias decompõem a matéria orgânica sob condições anaeróbicas, reduzindo os óxidos e hidróxidos de $\mathrm{Fe}^{3+}$ a $\mathrm{Fe}^{2+}$ e íons sulfato a sulfeto, levando a formação da Pirita $\left(\mathrm{FeS}_{2}\right)$, estável sob condições anaeróbias, mas quando há drenagem, com conseqüente exposição ao ar, ocorre oxidação da Pirita formando o ácido sulfúrico. Se a quantidade de ácido produzida é maior que a capacidade de neutralização do solo, produz-se uma acidificação dos solos e águas, podendo alcançar pH inferiores a 4,0 (Hart, 1959).
} 
Nas condições de anoxia há o controle da dinâmica dos elementos traço dos Manguezais, e estes funcionam como "filtros" naturais que dificultam a migração destes elementos ao ambiente costeiro. Ou ainda, como citado por Lacerda et al. (1993) e Harbinson (1986), o principal metabolismo da micro-biota anaeróbica dos solos é a sulfato redução que tem como subproduto o significativo aumento das concentrações de sulfetos nas águas intersticiais, que por sua vez influenciam diretamente a solubilidade dos elementos traço. Estudos realizados por Lacerda et al. (1988) concluem que os Manguezais atuam como sumidouro de elementos traço, a médio prazo, pois importam mais sedimentos, e conseqüentemente elementos traço, do que exportam.

Em resumo, a acumulação de elementos traço é condicionada pela decomposição anaeróbica orgânica via sulfato redução que resulta na liberação de sulfetos e na precipitação dos metais, processos intimamente dependentes do equilíbrio das condições ambientais próprias do Manguezal que podem facilmente ser pertubadas por impactos antrópicos, revertendo os processos não sendo os metais mais precipitados (como Pirita), mas, ao contrário, são biodisponibilizados ao meio (Krauskopf, 1956).

\section{$\underline{\text { Interação solo - planta }}$}

A variabilidade estrutural dos bosques está limitada pela plasticidade das espécies envolvidas e sua capacidade de ajustar-se ao meio onde se desenvolve (Coelho Jr., 1998).

Os Manguezais se desenvolvem melhor em locais onde o substrato se apresenta menos consistente, com baixa declividade e granulometria fina (Schaeffer-Novelli, 1995), o que é característica dos solos de Manguezal, compostos por sedimentos tipicamente argilosos e lamas argilo-arenosas. Entretanto estes bosques podem crescer em solos com textura e composições químicas diferentes, tendo cada espécie sua preferência. 
Em um ambiente de elevada salinidade a absorção de água e de nutrientes é dificultada. Isto porque as relações de troca de água e nutrientes entre o meio externo (o solo) e o meio interno das células das raízes são afetadas pela osmose. Graças a este fenômeno a água e substâncias nela dissolvidas podem passar para dentro e para fora da célula sempre que houver diferenças nas concentrações de substâncias dissolvidas no meio externo e no meio interno, isto é, diferenças de pressão osmótica. Como nos solos dos Manguezais a concentração de sais é elevada, o equilíbrio entre as pressões osmóticas tende a ser restabelecido através da migração de água para fora do meio intracelular. Para evitar esta perda de água e facilitar a absorção de nutrientes, as plantas devem manter altas concentrações de sais em seu interior, a fim de que sua pressão osmótica se iguale à do meio externo. A variabilidade da pressão osmótica do solo, porém, é muito ampla devido ao movimento das marés, às chuvas e à evaporação, que alteram drasticamente a concentração dos sais nele depositados. Logo, as plantas não só precisam concentrar sais em suas células, como também devem desenvolver mecanismos capazes de equilibrar rapidamente as concentrações internas de sais em resposta às variações de salinidade do meio externo (Lacerda, 1984).

Vannucci (1999) ressalta que as características físicas do solo parecem ter a mesma importância que as propriedades químicas na determinação do crescimento e da saúde dos Manguezais. Assim, a biomasa do sistema radicular, tanto acima como abaixo da superfície, pode ser, sob certas condições, maior do que a biomassa acima do solo constituída pelos troncos, ramos, folhas, flores e frutos. Os substratos anóxios induzem 0 desenvolvimento de raízes aéreas em espécies que normalmente não as possuem, por exemplo, Avicennia spp que apresenta aumento de lenticelas nas partes expostas e desenvolvimento do aerênquima em toda a planta, para melhor ventilação. 
Coelho Jr. (1998) destacou preferência dos bosques de Manguezal com $L$. racemosa e $A$. schauerianna em substratos com teores de matéria orgânica abaixo de $25 \%$ e sedimento com predominância da fração arenosa e em sedimentos colonizados por $R$. mangle a quantidade de matéria orgânica é maior. Carmo et al. (1998a) descrevem o menor desenvolvimento estrutural do Manguezal de Rio Reis Magos e a dominância de L. racemosa, relacionada ao baixo teor de matéria orgânica no sedimento arenoso. No trabalho de Cuzzuol \& Campos (2001), pode-se observar que o substrato de $A$. germinans e $L$. racemosa é de constituição argilosa enquanto $R$. mangle é arenosa.

\section{$\underline{\text { Interação solo - fauna }}$}

A fauna do solo dos Manguezais é representada por moluscos, anfípodos, gastrotríqueos, nematódes, entre outros. Destacam-se a Uca (Caranguejo chama maré) e outros caranguejos, que podem ser muito abundantes especialmente na faixa da franja do Manguezal (Vannucci, 1999). O autor op cit, destaca a importância dos animais cavadores que promovem a ventilação e inundação das camadas subsuperficiais do solo com a entrada da água nas galerias. Mesmo os animais de menor tamanho podem ser tão abundantes que têm atuação significativa na aeração das camadas mais profundas, influenciando a configuração do solo.

Ressalta-se ainda, a atuação dos animais na reciclagem dos nutrientes nos ecossistemas de Manguezal. Lacerda (1984), cita que ao contrário dos principais ecossistemas florestais dos trópicos onde ocorrem sofesticadas associações biológicas que garantem que os nutrientes permaneçam mais tempo no ecossistema, as florestas de Manguezais apresentam poucos mecanismos de reciclagem de nutrientes. Nos Manguezais, a reciclagem se restringe à atividade de animais, principalmente caranguejos, no sedimento. 
A superfície do lodo dos Manguezais nas florestas bem desenvolvidas e regularmente inundadas pelas marés é em geral sempre quente, rica em matéria orgânica, e úmida; constituindo assim, um bom meio de cultura, vivo de bactérias e fungos onde ocorre a formação de sais nutrientes (processo de mineralização) (Schaeffer-Novelli, 1995).

Lacerda (1984) destaca que o ecossistema Manguezal é muito aberto, com constantes fluxos de nutrientes dissolvidos para dentro do ecossistema, e de detritos e outras partículas para fora, sendo exportador de grandes quantidades de matéria orgânica, colonizados por uma flora e fauna microbianas que os enriquecem em compostos orgânicos altamente energéticos (como proteínas e aminoácidos) que são básicos às cadeias alimentares costeiras.

Os processos descritos tornam os Manguezais os principais responsáveis pela manutenção da cadeia alimentar costeira e também pela atividade pesqueira na maioria das áreas tropicais.

\subsubsection{Adaptações das espécies}

Adaptação é um processo final de ajustamento dos organismos ou populações às condições ambientais, de modo que possam sobreviver, reproduzir-se e desenvolver-se, ou seja, é o meio pelo qual os organismos respondem aos padrões existentes no ambiente (Schaeffer-Novelli, 1995).

A vegetação dos Manguezais é controlada principalmente pela hidrologia, fisiografia e clima, que condicionam um ambiente cuja característica principal é a instabilidade, com o substrato movediço e quase sempre em movimento de deposição ou erosão, inundações constantes, salinidade tanto na água como no solo e condições redutoras e anóxicas (Lacerda \& SchaefferNovelli, 1992 e Oliveira et al., 1998). 
Estas condições físicas e químicas muito variáveis impõem grandes limitações aos seres vivos que habitam e freqüentam o Manguezal (Ambiente Águas, 2002), de forma que as espécies desenvolveram, segundo Walsh (1974), adaptações morfológicas, fisiológicas e reprodutivas que possibilitam a colonização deste espaço, tais como fixação mecânica em solo frouxo, raízes respiratórias, mecanismos de aeração, mecanismos especializados de viviparidade e dispersão e desenvolvimento de estruturas xenofíticas devido à salinidade do solo. Estes mecanismos serão detalhados na seqüência.

Tanto as espécies da flora como da fauna estão eficientemente adaptadas às mudanças bruscas que ocorrem naturalmente no ambiente, porém é necessário destacar, que no caso da flora, o número de espécies com tais adaptações é reduzido, implicando em menor diversidade (Ceará, 1992).

\section{Viviparidade e dispersão}

A viviparidade é um fenômeno pelo qual o embrião se desenvolve ainda preso à árvore-mãe e também durante o processo de dispersão (não apresentando dormência nem germinação propriamente ditas). Nesses casos, o termo semente é substituído por propágulo. Os propágulos acumulam grande quantidade de reservas nutritivas, permitindo sua sobrevivência enquanto flutuam por longos períodos até encontrarem ambiente adequado à fixação. Além desta estratégia adaptativa para dispresão, a viviparidade aumenta também a resistência das plântulas à salinidade (proteção dos embriões contra o meio salino, tendo o zigoto um desenvolvimento contínuo até formar um novo rebento antes de desprender-se da planta-mãe) permitindo maior probabilidade de sobrevivência (FEEMA, 1979; Schaeffer-Novelli, 1995). 
Em Rhizophora, segundo Rabinowitz (1978a) a viviparidade da planta mãe produz propágulos na forma de grandes hipocótilos. A queda dos propágulos ocasiona a separação dos cotilédones (que permanecem na árvore), e a fixação no substrato, que pode partir da posição vertical ou horizontal ou pode também flutuar e ser transportado para outros locais. Em Avicennia os propágulos são leves, com grande capacidade de flutuação e, após a separação da planta-mãe, os cotilédones ficam expostos devido à perda do pericarpo coriáceo, o hipocótilo então se alonga e as raízes começam a crescer. Em Laguncularia os propágulos são pequenos, o pericarpo serve como uma bóia e não se desprende até o enraizamento.

A dispersão no caso das espécies do Manguezal é condicionada pela flutuabilidade e alta longevidade dos propágulos que permite transporte a longas distâncias, e ainda, a capacidade de fixação ao substrato lodoso, especialmente no caso da Rhizophora, cujo eficiente sistema de reprodução apresenta desprendimento do propágulo da árvore, que penetra na lama, auto-plantandose quando da queda em posição horizontal e com a parte mais pesada (ponto de origem das raízes) voltada para baixo (Leonel \& Simões, s/d).

Nas experiências de Rabinowitz (1978b) demonstrou-se que, em água salgada, a longevidade dos propágulos de Rhizophora é de mais de um ano, os de Avicennia é de 110 dias e de Laguncularia 35 dias (FEEMA, 1979).

\section{$\underline{\text { Tolerância à salinidade }}$}

A variação na freqüência de inundação das marés pode acarretar diferenças nas concentrações de sal no sedimento. De modo geral, nos Manguezais próximos ao mar a salinidade é maior e nos bosques próximos às margens dos rios é menor. Entretanto, em locais onde a maré chega poucas vezes ao dia ou onde há menor influência da água doce, as salinidades podem ser tão elevadas que as plantas não crescem (Schaeffer-Novelli, 1995). 
Em climas úmidos, a zona interna dos Manguezais mostra condições opostas aos de climas secos ou com secas estacionais. Estas zonas recebem água doce do lençol freático, como produto da precipitação e da drenagem superficial. Os gradientes de salinidade são inversos. Os sais contidos nos sedimentos das zonas dos bosques são fortemente diluídos por uma grande quantidade de água doce disponível através da chuva e da drenagem superficial (Hutchings \& Saenger, 1987).

O gradiente de salinidade é apontado também por Jimenez (1985) que especifica que a salinidade intersticial dos sedimentos pode ser diretamente influenciada por processos que ocorrem na superfície, como salinidade da água das marés, tempo e freqüência de inundação, pluviosidade, taxa de evaporação, propriedade de retenção do solo e run-on menos run-off, de forma que na zona interna dos bosques, o balanço hídrico está dominado por padrões de precipitação, evapotranspiração e drenagem e na zona externa, por processos estuarinos, sendo a parte mais dinâmica dos Manguezais.

Em relação à salinidade nos Manguezais, Davis (1940), ressaltou como aspectos relevantes:

- existência de uma grande variação anual de salinidade;

- a água salgada não é necessária à sobrevivência de qualquer espécie do Manguezal, porém oferece a estas, vantagens na competição com espécies não tolerantes ao sal;

- a salinidade é geralmente maior e menos variável na água intersticial que na água superficial;

- as condições salinas no sedimento estendem-se mais internamente que nas áreas atingidas pela preamar normal, uma vez que estas promovem a lavagem do sedimento. 
Como as plantas do Manguezal sobrevivem a tais condições ambientais, são consideradas por Vannucci (1999), sob o ponto de vista ecológico, como halófitas ou pelo menos tolerantes à salinidade, apresentando mecanismos morfológicos e fisiológicos voltados ao funcionamento como: barreira osmótica de penetração de cloreto de sódio e outros sais nas raízes; secreção do excesso de sal por glândulas; acumulação e imobilização de sais em diferentes tecidos.

Schaeffer-Novelli (1995) acrescenta outros mecanismos fisiológicos adaptativos das plantas halófitas, ressaltando que estes permitem o:

- desenvolvimento de folhas pequenas e pêlos armazenadores de água;

- alta absorção de água para manutenção constante das concentrações de sais no interior da célula, regulando o turgor;

- síntese e acúmulo de solutos orgânicos que ajudam a manter estável a concentração de sais dentro da célula;

- minimização da ação dos sais pela compartimentalização em vacúolos.

Vários autores abordaram e discutiram tais processos reguladores, conforme apresentado a seguir.

Mitsch \& Gosselink (1993) citam que as espécies de Manguezal são consideradas halófitas facultativas pois não requerem água salgada para crescer mas são tolerantes à alta salinidade. A exclusão de sal pelas raízes permite absorção de água salgada, sendo que as membranas celulares atuam como filtros que excluem íons de sal quando a água é succionada pela pressão negativa no xilema (desenvolvida graças à transpiração das folhas). 
O funcionamento metabólico de plantas halófitas de ambientes de alta salinidade se dá por íon extrusão, mecanismo presente em algumas espécies de Manguezal como Avicennia e Spartina, que possuem glândulas epidérmicas para exudação de sal (Coelho Jr., 1998). Outro mecanismo, apontado por Walsh (1974), é a suculência em água salgada. FEEMA (1979) destaca que para a $R$. mangle o desenvolvimento é reduzido ou inibido sob altas concentrações salinas, sendo maior sob baixas concentrações (25\%), com aumento do peso, do número de folhas e superfície foliar, crescimento longitudinal das raízes e do hipocótilo.

Carter et al. (1973) estudando o mesmo tema por meio do método das trocas gasosas, concluiu que a produtividade primária bruta de $R$. mangle decresce com o aumento da salinidade, enquanto que para $A$. schaueriana e $L$. racemosa ocorre o oposto. Schaeffer-Novelli (1995) complementa, apontando que Rhizophora é menos tolerante ao sal, desenvolvendo-se em locais onde a água do sedimento (água intersticial) apresenta teores menores que 50 ppm. Avicennia é dos gêneros mais tolerantes, conseguindo sobreviver em locais aonde as águas intersticiais chegam a conter 65 a 90ppm. Laguncularia apresenta tolerância intermediária em comparação com os gêneros anteriores.

O enfoque de Tomlinson (1986) é a capacidade de excreção de sal de algumas espécies do Manguezal. Nas excretoras de sal, como A. schaueriana, a concentração de sal na seiva do xilema é relativamente alta (10\% da concentração salina do mar), sendo o sal excluído parcialmente nas raízes e excretado principalmente por via metabólica (glândulas de sal). Nas espécies não excretoras, como $R$. mangle (filtradora), a seiva do xilema possui uma concentração de sal menor que 1\%, porém ainda concentra dez vezes mais sal que as plantas que não são típicas de Manguezal (como o Hibiscus), sendo a exclusão mais eficiente, e portanto, a absorção é menor. Essas espécies, apesar de não serem secretoras, perdem sal através da superfície das folhas, possivelmente pela transpiração cuticular. 
Chapman (1975) aponta ainda uma outra forma de perder sal, considerada questionável, que é por meio do descarte da folha, uma vez que o Manguezal renova as folhas duas vezes ao ano. Vannucci (1999) apresenta outras espécies associadas ao Manguezal, mas não exclusivas (Terminalia, Hibiscus, Thespesia, Erithrina e Casuarina), como tolerantes à salinidade.

\section{Aeração e fixação}

As plantas típicas do Manguezal apresentam adaptações nas raízes para as trocas gasosas. Tanto nos rizóforos como os pneumatóforos (raízes respiratórias) existem estruturas (lenticelas), que facilitam o fluxo dos gases $\left(\mathrm{O}_{2}\right.$ e $\mathrm{CO}_{2}$ ) entre planta e ambiente durante a flutuação das marés (SchaefferNovelli, 1995 ; CETESB, 1979 e Leonel \& Simões, s/d; Macedo, 1986).

O sistema radicular das espécies de Manguezal é pouco profundo, uma vez que o sedimento carece de aeração adequada, produzindo grande quantidade de compostos minerais reduzidos, o que resulta em grande toxidade para os tecidos das raízes, pois conforme aumenta a profundidade, a quantidade de Oxigênio se reduz rapidamente e o sedimento se converte em meio limitante para o sistema radicial. Assim, as zonas subterrâneas, responsáveis pela absorção de nutrientes estão localizadas próximas a superfície do sedimento (Coelho Jr., 1998; Tomlinson, 1986).

Lamberti (1969) relata que as raízes aéreas permanecem expostas na atmosfera pelo menos uma parte do dia. Fisiologicamente a necessidade desse tipo de raiz está relacionada com o substrato anaeróbico e a necessidade da oxigenação atmosférica. Walsh (1974) acrescenta que as raízes aéreas são denominadas escoras e desempenham dupla função: funcionam como porta de entrada de ar atmosférico por pequenas lenticelas e atuam como suporte para o vegetal no sedimento inconsistente. 
As raízes aéreas são características da espécie Mangue vermelho, enquanto que os pneumatóforos são característicos do Mangue branco e do Mangue preto, que possuem o sistema radicular muito ramificado horizontalmente e em disposição radiada, com ramos com mais de $5 \mathrm{~m}$ de comprimento e profundidade não superior a $0,5 \mathrm{~m}$, de onde nascem os pneumatóforos (20-30cm de altura por 1,5 a 2,0cm de diâmetro). Essas raízes são de consistência esponjosa, providas de pequenas lenticelas (pneumatódios) e tecido cortical com espaços intercelulares, responsáveis pelo armazenamento de ar e pela consistência esponjosa do órgão.

A Spartina também apresenta adaptação ao ambiente inundado e com pouca oxigenação, sendo portadoras de cavidades próprias para armazenar ar nas partes aéreas da planta, e tais estruturas auxiliam adicionalmente, a flutuação (FEEMA, 1979 ; Ranwell, 1972).

\subsubsection{Fauna}

Os Manguezais abrigam grande variedade de fauna que inclui um conjunto de animais residentes habitantes da zona entre marés dominada por crustáceos como caranguejos, cracas e moluscos; animais semi-resistentes constituídos principalmente por peixes que passam uma fase da vida no Manguezal ou avançam e recuam diariamente com a maré; e por animais visitantes constantes ou esporádicos (Leonel \& Simões, s/d).

A maior parte da fauna vem do ambiente marinho como moluscos, crustáceos e peixes. A água doce contribui principalmente com crustáceos e peixes. Do ambiente terrestre provêm aves, répteis, anfíbios, mamíferos e insetos (Schaeffer-Novelli, 1995). 
Os crustáceos decápodos são característicos de Manguezais e desempenham papel importante na manutenção da dinâmica do Manguezal, pois fragmentam folhas que caem das árvores, facilitando a utilização por outros organismos menores e, ao construírem suas tocas, reviram a lama, trazendo à superfície grande quantidade de matéria orgânica. O Manguezal ainda abriga uma fauna microscópica composta principalmente por bactérias, protozoários, microcrustáceos, entre outros, cujo papel é a manutenção e funcionamento dinâmico do ambiente (Ceará, 1992).

A fauna associada aos Manguezais da Baixada Santista é composta por 26 espécies de aves, 11 de peixes, 10 de crustáceos (6 de caranguejos e 4 de siris), 12 moluscos (7 de lamelibrânquios e 5 de gastrópodes), 19 anelídeos poliquetas, 5 equinodermes, 2 cnidários, 1 pantópoda, 2 briozoários, além de nematódeos e nemertíneos não identificados (Novelli \& Lacerda, 1994).

Com a má utilização do Manguezal, devido ao lançamento de lixo e dejetos, têm surgido insetos nocivos, vetores de doenças como observado por Schaeffer-Novelli (1995), que ressalta insetos como mariposas, borboletas, besouros, mutucas, moscas, mosquitos, paquinhas, entre outros, que têm suas larvas fitófagas alimentando-se dos tecidos das plantas de Manguezal.

\subsubsection{Função ecológica e sócio-econômica}

O Manguezal é um ecossistema dinâmico de grande importância ecológica e geomorfológica, porém seu reconhecimento por parte do mundo científico é recente. A exploração direta do estuário e da vegetação do Manguezal pelo homem vem sendo exercida desde a mais remota antiguidade, com uso dos recursos como fonte de alimentos, bebidas, forragens, remédios, para construção de quilhas de barcos, postes, tochas, totens religiosos, polpa de papel, cobertura de casas, curtimento do couro, utilização da madeira como fonte de combustível, entre outros (FEEMA, 1979). 
Mastaller (1990), Citron \& Schaeffer-Novelli (1981), Soares (1997), Macedo (1986) e Choong et al. (1990) destacam as funções do Manguezal:

- Constituem importante fonte de detritos para as águas costeiras adjacentes, tanto através da produção de serapilheira como da ciclagem de nutrientes por seus constituintes, formando assim o elo básico de cadeias alimentares detríticas economicamente importantes;

- Funcionam como área de abrigo, reprodução, desenvolvimento e alimentação de espécies marinhas, estuarinas, terrestres e líminicas;

- Atuam como ponto de pouso para diversas espécies de aves migratórias;

- Contribuem para manutenção da diversidade biológica costeira;

- Protegem a linha da costa, evitando erosão e assoreamento dos corpos d’água adjacentes;

- Agem na absorção e imobilização de produtos químicos, como metais, além de contribuir para o tratamento de esgoto;

- São fonte de produtos para comunidades humanas costeiras, usado para fins culturais, recreativos e lazer, para pesquisa científica, e como recurso paisagístico.

Vários outros autores tais como Schaeffer-Novelli (1995); Cintrón et al. (s.d.), Moura et al. (1998), Mastaller (1990), Grasso et al. (1995), Araújo et al. (1998), Macedo \& Rocha (1985), Santos \& Schaeffer-Novelli (1985) abordam o tema detalhando as inúmeras funções do Manguezal, considerado importante transformador de nutrientes em matéria orgânica e gerador de bens e serviços.

Ressalta-se entre as funções desempenhadas pelos Manguezais, que estes podem atuar como reservatórios regionais de água, retendo a umidade durante os períodos de seca, como estabilizador ambiental e climático regional. Estudos em áreas de Manguezal poluídas mostraram que algumas plantas podem acumular seletivamente metais originários de águas industriais 
residuais e que estes também funcionam como purificadores, neutralizando os tóxicos orgânicos e as bactérias nocivas. Assim, solo e plantas do Manguezal conseguem reter muitos agentes poluentes tais como os metais, o que torna vital sua manutenção, especialemnte em áreas poluídas (Ceará, 1992 e Menezes et al., 1998).

\subsubsection{Legislação}

O Manguezal tem reconhecidamente importância ecológica, sendo suas áreas amparadas por legislação federal (Rossi \& Mattos, 1992), além de diversos dispositivos infra-constitucionais (leis, decretos, resoluções, convenções). A observação desses instrumentos legais impõe uma série de restrições ao uso e/ou ações nessas áreas (Novelli \& Lacerda, 1994).

Schaeffer-Novelli (2000), Cunha Lignon (2001), ressaltam a legislação federal que versa sobre o ecossistema Manguezal:

- É considerado no Art. 225 da Constituição Federal do Brasil (1988) como Patrimônio Nacional, tendo assegurada sua preservação.

- É considerado vegetação de preservação permanente conforme definido no Código Florestal (Lei n 4.771/65) e Res. CONAMA nº 4 de 18/09/85.

- Não pode ser substituido por empreendimentos de aqüicultura, sendo tal ação ilegal segundo a Lei $n^{0} 9.605 / 98$ de crimes ambientais.

- É referido na Lei 7661/88 e na Resolução CONAMA 005/97, assim como no Plano Nacional de Gerenciamento Costeiro (PNGC), que no art. $3^{\circ}, \S 1^{\circ}$, dá "prioridade à conservação e proteção dos recursos naturais, renováveis e não renováveis, dentre os quais os Manguezais.

- É referido no Decreto Federal nº $750 / 93$ que destaca as restrições de supressão em áreas de Mata Atlântica e seus ecossistemas associados, como o Manguezal. 
Em relação à legislação Estadual, Cunha-Lignon (2001) cita a Constituição do Estado de São Paulo (1989), que no capítulo IV - Do Meio Ambiente, dos Recursos Naturais e do Saneamento, determina no Art. 196, os espaços territoriais especialmente protegidos, e no Art. 197 determina que os Manguezais são Áreas de Preservação Permanente (APP).

\subsubsection{Tensores naturais e antrópicos}

Segundo a definição de Seyle citado por Silva (1986), tensor é qualquer fator ou situação que induz um sistema a mobilizar seus recursos, gastando mais energia para manter seu equilíbrio homeostático. Os principais impactos registrados no Manguezal são provocados por tensores de ordem natural, antrópica e mais intensamente pela ação conjunta de ambos.

Lugo (1998) classifica os tensores em cinco tipos:

- Os que alteram a natureza da fonte principal de energia. Ex: represamento.

- Os que desviam uma parte da energia da fonte principal antes que seja incorporada ao sistema. Ex: sombreamento.

- Os que removem energia potencial antes de ser armazenada mas depois de ter sido transformada pela fotossíntese. Ex: epidemia de herbívoros.

- Os que removem biomassa. Ex: fogo.

- Os que aumentam a taxa de respiração. Ex: alteração de temperatura.

Um tensor pode operar de maneira contínua (modo crônico), com perda contínua de energia impedindo o desenvolvimento do ecossistema ou como um episódio passageiro (modo agudo) (Rodrigues, 1997). 
Os Manguezais estão sujeitos a tensores crônicos ou agudos (Mastaller, 1990). A maioria dos fenômenos naturais atuam como tensores agudos, com ocorrência por curto período de tempo, efeitos temporários e possibilidade de reversão à qualidade ambiental anterior. Ao contrário, eventos induzidos pelo homem em geral atuam como tensores crônicos que se estendem por períodos mais longos, com ação e impactos a longo prazo, podendo inclusive provocar a morte do Manguezal (Schaeffer-Novelli, 1995).

Os tensores antrópicos são considerados os agentes ou processos causadores de impactos ambientais diretamente vinculados à ação humana. Silva (1986) e Mastaller (1996) relacionam os principais tensores desta origem:

- Desmatamento (acelera o processo de erosão das margens dos canais, alterações no regime hídrico causando incremento da salinidade dos solos, eliminação ou diminuição da quantidade de espécies da flora e fauna);

- Aterramento das áreas (redução do ecossistema, diminuição da capacidade de retenção de águas superficiais, interferência sobre a regeneração e diminuição da disponibilidade de recursos naturais);

- Lançamento de dejetos nas águas (alteram as propriedades físicoquímicas causando eutrofização, aumento da DBO e contaminação patogênica e metais);

- Contaminação com derramamento de petróleo (mortalidade de espécies aquáticas sensíveis como os organismos filtradores, com conseqüente diminuição dos recursos pesqueiros);

- Fogo (causa compactação e diminuição da umidade do solo, degradação da vegetação com eliminação seletiva e alteração da complexidade estrutural e, eliminação completa ou parcial da fauna);

- Caça e pesca (diminuição seletiva de espécies, desestruturação da cadeia alimentar e diminuição da potencialidade de recursos alimentares). 
Diversos outros autores citam a destruição dos Manguezais enfatizando as causas e efeitos associados. Dentre estes: Araújo et al. (1998), Carmo et al. (1998a), CETESB (1977), Cintrón \& Schaeffer-Novelli (1981), Eysink et al. (1997), Eysink et al. (1998a), Eysink et al. (1998b), FEEMA (1979), Ceará (1992), Luiz-Silva et al. (2002), Lacerda (1984), Menezes et al. (1998), Novelli \& Lacerda (1994), Ramos e Silva (1996), Rossi \& Mattos (1992), Silva (1986), Singh (1994), Camacho et al. (1980), Ambiente águas (2002), Vannucci (1999), além de outros. O consenso dos autores é de que a perda ambiental é sempre grande e advém especialmente da conversão do uso do solo ou do uso incorreto e/ou superdimensionado dos recursos do Manguezal.

\subsubsection{Situação quanto à degradação}

No Estado de São Paulo, pode-se observar, por meio de levantamentos realizados por Herz (1991) que mais de 10\% dos Manguezais (cerca de 27.000ha) encontravam-se alterados ou degradados. Menezes et al. (1994) acrescentam que esta degradação está concentrada em duas regiões do estado: Baixada Santista e Iguape.

No caso da Baixada Santista, 10\% dos $1.329 \mathrm{~km}^{2}$ de área supreficial correspondem à planície de maré originalmente ocupada por Manguezal, e desta área, 31\% $\left(42 \mathrm{~km}^{2}\right)$ estão degradados, principalmente na região de Santos (CETESB, 1979), especialmente em função da poluição industrial e ocupação urbana (Lamparelli et al., 1997).

O município de Cubatão, na Baixada Santista, é provavelmente o mais alterado entre os estuários brasileiros como resultado da intensa degradação ambiental e consequente comprometimento dos Manguezais (Menezes, 1999). Silva et al. (1991) ressalta que é o mais degradado da região, sendo que dos $29 \mathrm{~km}^{2}$ da superfície original de Manguezais restam apenas 17\% em bom estado de conservação no município. 
São vários os exemplos de impactos que têm provocado esta degradação, como: derramamentos de óleo (CETESB, 1989); aterros; deposição de resíduos sólidos e lixões; efluentes industriais e domésticos (Eysink et al., 1997), extração de areia; abertura de canais; construção de ferrovias e rodovias (interrupção da circulação da água), atividades extrativistas e projetos de maricultura (Eysink et al., 1998b). Estes fazem com que haja uma perda significativa dos Manguezais e, conseqüentemente, da sua função de precipitador de partículas em suspensão, de retentor e até de imobilizador de contaminantes orgânicos e inorgânicos (metais), além de deixar de oferecer um ambiente propício para reprodução e crescimento de inúmeras espécies de organismos aquáticos à população ribeirinha (Eysink et al., 1998b).

CETESB (2001a) em 1974 avaliou os impactos da poluição nas águas, sedimentos e organismos aquáticos do estuário e baía de Santos, e em 1984, da contaminação e toxidade nos Rios Perequê, Cubatão, Mogi, Perdido e Piaçaguera em Cubatão, constatando comprometimento ambiental aquático em todos estes locais, devido à degradação pela poluição de origem doméstica e industrial (contaminação química e microbiológica) e alterações físicas dos habitats (processos erosivos, assoreamento, aterros e intervenções no sistema de drenagem). As avaliações foram ampliadas publicou-se relatório com o levantamento da contaminação ambiental do Sistema Estuarino Santos e São Vicente (1999) que abrangeu 26 pontos de coleta de água, sedimentos, peixes, crustáceos e moluscos; análise de 120 parâmetros, dentre estes os metais. 


\subsection{Contaminação por metais}

\subsubsection{Os metais}

O termo metal pesado tem sido utilizado indiscriminadamente em vários casos, como por exemplo, para os elementos não-metálicos Arsênio e Selênio. Alguns autores relacionam o termo com a densidade mínima dos metais (variável de 4,5, 5,0 e 6,5 g/ $/ \mathrm{cm}^{3}$, conforme o autor consultado), ou ainda, a elementos com peso específico maior de $5 \mathrm{~g} / \mathrm{cm}^{3}$ ou que possuem número atômico maior que 20.

No presente trabalho os metais estudados constam da listagem de metais denominados pesados, avaliados pela CETESB (CETESB, 2001a) que inclui Cádmio (Cd), Chumbo (Pb), Cobre (Cu), Cromo (Cr), Estanho (Sn), Mercúrio $(\mathrm{Hg})$, Níquel (Ni) e Zinco $(\mathrm{Zn})$, e que são a seguir brevemente caracterizados.

\section{Cádmio}

Dentre os metais é o mais móvel em ambientes aquáticos, sub-produto da mineração do Zinco, bioacumulativo, persistente no ambiente, cancerígeno, causa de hipertensão e doenças do coração. A exposição acentuada via oral pode resultar em sérias irritações no epitélio gastrointestinal, náusea, vômito, salivação, dor abdominal, cólica e diarréia. Foi utilizado como amálgama por dentistas e na indústria eletrônica (Macedo, 1986).

Encontrado em baixas concentrações na crosta terrestre (principalmente como sulfeto em depósitos minerais que contêm Zn), ocorre em associação com $\mathrm{Pb}$ e $\mathrm{Cu}$ em minerais e minérios. Combustíveis fósseis e óleos podem conter traços deste elemento. Sua forma mais freqüente nos solos é $\mathrm{Cd}^{+2}$ e a mobilidade é controlada pelo $\mathrm{pH}$ e potencial redox. A concentração depende da rocha de origem, podendo variar de 0,07 a $1,1 \mu \mathrm{g} / \mathrm{g}$, sendo que em 
solos raramente ultrapassam a 0,5 $\mathrm{g} / \mathrm{g}$. Foi encontrado em efluentes líquidos no Rio Cubatão e bioacumulado no musgo Sphagnum. Nos sedimentos da

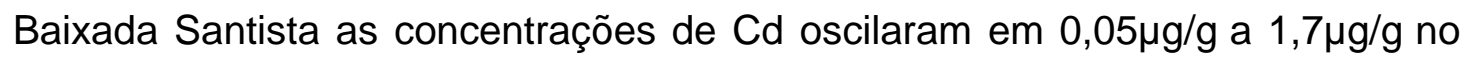
Canal da Cosipa. Existe um gradiente decrescente de $\mathrm{Cd}$ a partir dos Rios Piaçaguera e do Canal em direção ao mar. O metal está amplamente difundido nos ecossistemas costeiros e concentrado próximo as fontes (CETESB, 2001a).

\section{Chumbo}

Apresenta maciez, maleabilidade, facilidade de moldagem; é utilizado em tintas, baterias, isolante de Raio $X$. Causa problemas neurológicos, cegueira, paralisia, danos no rim (dano irreversível aos néfrons) e ao sistema hematopoético, diminuição do crescimento e dificuldade de manutenção da postura ereta. Durante a gravidez pode provocar natimortos e abortos. Eleva a pressão arterial e é agente teratogênico (Macedo, 1986).

Ocorre em concentrações de 0,1 $\mathrm{gg} / \mathrm{g}$ (rochas ultramáficas e calcários) a $40 \mu \mathrm{g} / \mathrm{g}$ (rochas magmáticas ácidas e sedimentos argilosos), sendo a faixa de normalidade entre 15 a $25 \mu \mathrm{g} / \mathrm{g}$. Ocorre como contaminante em efluentes de indústrias de refino de petróleo, petroquímicas e siderúrgicas. O limite da legislação brasileira para consumo humano é de 2,0 $\mu \mathrm{g} / \mathrm{g}$ (CETESB, 2001a).

Cobre

A contaminação causa anemia (síntese deficiente de hemoglobina); o excesso leva a vomitos, hipotensão, icterícia e até morte (Macedo, 1986). Metal de ampla distribuição na crosta terrestre ocorrendo em rochas magmáticas em valores até $100 \mu \mathrm{g} / \mathrm{g}$. Nos solos os valores normais oscilam entre 10 e $80 \mu \mathrm{g} / \mathrm{g}$. Amplo emprego industrial e doméstico. Na Baixada Santista apenas siris do Rio Piaçaguera apresentam valores acima do limite legal, nos peixes acumula-se no fígado, descartado para consumo (CETESB, 2001a). 
Cromo

É essencial para o metabolismo de glicose, proteínas e gordura de mamíferos, sendo que, os sinais de deficiência em humanos incluem perda de peso e tolerância diminuída à glicose. Os compostos de $\mathrm{Cr}$ são corrosivos e reações alérgicas na pele ocorrem logo após o contato, independente da dose. Níveis elevados podem levar a ulcerações na pele, perfuração no trato respiratório e irritação do trato gastrointestinal. Danos ao rim e fígado já foram relatados, além de serem cancerígenos, provocarem inflamação nasal, câncer de pulmão e perfuração do septo nasal (Macedo, 1986).

Ocorre em vários minerais, associado a outros metais e pode alcançar valor médio de $126 \mu \mathrm{g} / \mathrm{g}$ na crosta terrestre. É utilizado como anti-corrosivo em sistema de resfriamento, em tijolos refratários e em ligas metálicas. Sais de Cromo são utilizados em curtumes, laboratórios e indústria química. Nos sedimentos, as maiores concentrações na Baixada Santista estão próximas a Cosipa e Rio Piaçaguera (23 e 70 $\mathrm{g} / \mathrm{g}$ respectivamente) (CETESB, 2001a).

\section{Estanho}

Elemento que aparece como traço, sendo necessário à vida, porém sua ação bioquímica não é conhecida. Não se tem relatos de toxicidade promovida pelo elemento ou seus compostos mais simples, mas seus compostos organometálicos, como os trialquilcloretos e trialquilhidróxidos são muito tóxicos e bastante empregados contra ataques de fungos nas culturas do arroz e da batata (Unesp, 2005). 
Mercúrio

Encontrado em rochas magmáticas, rochas sedimentares e sedimentos argilosos. A concentração em perfis de solos virgens está relacionada ao material de origem e à entrada por via atmosférica, já que o metal é de fácil volatilização (lançado na atmosfera por atividade vulcânica). A acumulação está relacionada ao Carbono orgânico e Enxofre. As principais fontes de contaminação são indústrias de processamento de metais, produção de clorosoda, fabricação de pilhas, lâmpadas fluorescentes, aparelhos de medição e fungicidas, lodos de esgoto e outros resíduos. A legislação determina como 0,5 $\mu \mathrm{g} / \mathrm{g}$ o limite máximo em peixes, crustáceos e moluscos.

Acumulativo (principalmente no cérebro) causa cegueira, paralisia e pode ser letal. É levemente volátil à temperatura ambiente. Na forma líquida ou sais solúveis tem vapores corrosivos causadores de intoxicação aguda, afetando pele, mucosa, causando náuseas, vômito, dor abdominal, diarréia com sangue e danos aos rins, sintomas neurológicos como tremores, vertigens, irritabilidade, depressão, salivação, estomatite, diarréia, descoordenação motora progressiva, perda de visão e audição e deterioração mental (Macedo, 1986).

Níquel

Está presente na crosta terrestre com média de $56 \mu \mathrm{g} / \mathrm{g}$. É normalmente encontrado em efluentes líquidos industriais, principalmente em refinarias de petróleo, siderúrgicas e fábricas de fertilizantes e de celulose e papel. É essencial aos organismos, mas há indivíduos hipersensíveis. A exposição em ambiente de trabalho industrial causou irritações da pele e câncer dos pulmões. O metal causa dematite por contato, erupções da pele, gengivite, estomatite e tontura. A inalação de compostos de Ni aumenta a susceptibilidade a infecções respiratórias (Unesp, 2005). O limite máximo para organismos aquáticos definido pela legislação brasileira é de $5,0 \mu \mathrm{g} / \mathrm{g}$. 
Zinco

É um metal essencial para nutrição, tendo papéis enzimáticos, estruturais e regulatórios em muitos sistemas biológicos. A deficiência pode ocasionar crescimento retardado, anorexia, dermatite, sintomas neuropsiquiátricos e o excesso causa distúrbios gastrointestinais e diarréia, dano pancreático e anemia, paladar adocicado, secura na garganta e tosse (Macedo, 1986).

Amplamente distribuído na natureza, ocorrendo nos solos e, como nutriente essencial, nas plantas em geral. Nos solos, os valores de Zinco em áreas não poluídas variam de 10 a $30 \mu \mathrm{g} / \mathrm{g}$. Tem uso industrial inclusive para fabricação de telhas e utensílios. CETESB (2001a) informa que nos sedimentos da região da Baixada Santista houve acumulação especialmente próximo às fontes industriais. O Brasil não possui um limite específico para os organismos aquáticos destinado ao consumo humano, portanto considera-se o limite de $50 \mu \mathrm{g} / \mathrm{g}$ para a categoria "outros alimentos" presente na legislação.

\subsubsection{O Manguezal como armazenador de metais}

Os Manguezais atuam como eficientes barreiras biogeoquímicas ao trânsito de metais em áreas costeiras tropicais através da imobilização de metais nos sedimentos sob forma não biodisponíveis que, juntamente com certas adaptações fisiológicas típicas de árvores de Manguezal, reduzem sensivelmente a absorção de metais pelas plantas (Silva et al., 1990).

Assim, as áreas úmidas têm sido propostas como armazenadoras, "sinks" naturais de metais, que uma vez imobilizados no sedimento somente podem ser liberados por forte oxigenação e/ou absorvidos por vegetais e posteriormente liberados como detritos, embora os sedimentos, predominantemente anaeróbicos e argilosos, atuem principalmente imobilizando e tornando-os indisponíveis para o meio biótico (Harbison, 1986). 
Lacerda \& Abrão (1984) citam que os teores elevados de matéria orgânica, baixa oxigenação e posição em relação ao nível das marés possibilitam aos Manguezais acumular maior quantidade de metais no sedimento do que outros ecossistemas costeiros. O conteúdo de matéria orgânica parece ser o fator que controla o acúmulo de metais nesse sedimento; primeiro, por sua grande capacidade de adsorção quando comparada com a matéria inorgânica e, segundo, por manter o sedimento em estado reduzido.

\subsubsection{Contaminação e sintomas}

Apesar de existirem vários trabalhos desenvolvidos, ainda há grande desconhecimento sobre as relações causa-efeito da contaminação por metais em árvores de Manguezal. Algumas das adaptações fisiológicas dessas espécies para restringir a absorção do excesso de íons presentes nas condições salinas e redutoras do solo poderiam atuar como mecanismos de tolerância, reduzindo a absorção de metais (Lacerda, et al. 1993).

Os Manguezais toleram altos teores de metais devido às características físico-químicas do sedimento, protegendo as comunidades marinhas adjacentes (Menezes, 1999). Os metais interagem com os processos fisiológicos de animais e plantas, causando principalmente disfunções em seus sistemas enzimáticos. No caso específico das plantas de Manguezal, seu efeito é mais drástico quando afeta o mecanismo de regulação da concentração de sais (Lacerda, 1984 e Macedo, 1986).

Os sedimentos sempre vão conter íons de metais, mas as concentrações irão variar em função da geologia local e devido a alterações antropogênicas. Sedimentos não contaminados devem conter menos de 0,5mg/kg de $\mathrm{Hg}$ e Cd; menos de 50 mg/kg de Pb, Cr, Cu, Co e Ni; menos de 100 $\mathrm{mg} / \mathrm{kg}$ de $\mathrm{Zn}$ e menos de $1000 \mathrm{mg} / \mathrm{kg}$ de $\mathrm{Mn}$. 
CETESB (1989) classifica os sintomas de intoxicação presentes nas folhas em três grupos distintos: os necróticos, que envolvem processos de degeneração e morte das células e tecidos, como mancha, perfuração, murcha e amarelecimento; os hiperplásticos, que se manifestam pelo desenvolvimento exagerado de células e tecidos como a galha e enrolamento; e os hipoplásticos, que se expressam pela supressão ou exagerada redução de células e tecidos como a clorose, em que se observa a descoloração reversível dos órgãos verdes que passam a exibir tonalidades mais claras.

Em relação à herbivoria, a hipótese de que áreas de Manguezal mais estressadas possam apresentar maior herbivoria não foi confirmada pelos estudos realizados pela CETESB (1989).

\subsubsection{Comportamento dos metais no meio e na planta}

O comportamento de metais nos estuários é de difícil entendimento. Diversos estudos têm demonstrado as interações entre os metais e os minerais de sulfetos de Ferro autigênicos em ambiente sedimentar anóxico. comportamento destes está diretamente associado às condições físico-químicas no sedimento e água intersticial (Andrade \& Patchineelam, 2000). Estudos indicam que os metais sofrem influência da salinidade e do $\mathrm{pH}$, da concentração de material particulado, alcalinidade e força iônica (Schmitdt et al., 1998). Benoit et al. (1994), estudaram vários estuários no Golfo do México observando que a salinidade tem influência no comportamento do Ferro e do Manganês, embora não exista um padrão definido.

O sedimento de Manguezais com a espécie R. mangle mostra uma maior concentração de compostos de Enxofre reduzido que aqueles recobertos com Avicennia (Thibodeau \& Nickerson citados por Andrade \& Patchineelam, 2000). A rizosfera da Avicennia tende a ser mais rica em matéria orgânica e possui $\mathrm{pH}$ mais elevado. A Rhizophora influencia de forma menos efetiva as condições gerais do solo abaixo de sua rizosfera, sendo, por conseguinte 
altamente sulfídrica (Lacerda et al., 1993; Andrade \& Patchineelam, 2000). Os autores citaram que a Avicennia está apta a oxidar sua rizosfera, permitindo maior concentração de metais na fração reativa, possuindo um maior potencial redox que aquele de solos com Rhizophora. Assim, os ambientes com predomínio de Avicennia apresentam alta variabilidade nas condições redox e concentração de sulfetos. O perfil de maior biodisponibilidade de metais foi observado nos primeiros $5 \mathrm{~cm}$ em solos com Avicennia. Estes metais estariam associados a óxidos, hidróxidos, carbonatos ou adsorvidos em argilo-minerais e sulfetos metaestáveis, interferindo assim na concentração menor de minerais sulfídricos na região sedimentar.

Estudos efetivados em ambientes sedimentares no Golfo do México mostraram que a piritização de metais é um importante processo diagenético ao longo da coluna sedimentar. Em ambientes anóxico-sulfídrico (elevada concentração de $\mathrm{H}_{2} \mathrm{~S}$ e baixa de Fe-reativo) e anóxico-não sulfídrico (baixa concentração de $\mathrm{H}_{2} \mathrm{~S}$ e elevada de Fe-reativo) existe uma tendência geral de associação com o mineral Pirita na coluna sedimentar para $\mathrm{As}, \mathrm{Hg}, \mathrm{Mo}, \mathrm{Co}, \mathrm{Cu}$, $\mathrm{Ni}, \mathrm{Cr}, \mathrm{Pb}, \mathrm{Zn}$, entretanto estes metais são incorporados na Pirita em diferentes extensões. As concentrações dos metais-traço, Fe, Co, Ni e Cu demonstram que a especiação destes metais nas frações reativa e Pirita é diferenciada no sedimento recoberto por Avicennia e Rhizophora. A maior concentração dos metais associada à fração reativa no solo com Avicennia sugere que em função de sua rizosfera possuir um alto potencial oxidante, este ambiente propiciaria uma maior biodisponibilidade de metais-traço que aquele recoberto por Rhizophora (Huerta-Diaz, 1992).

Schmidt et al. (1998) observou que R. mangle apresentou concentrações mais elevadas de $\mathrm{Mn}$ que $L$. racemosa e $A$. schaueriana. Esse comportamento talvez possa ser explicado pela reduzida taxa de decomposição, com estruturas remanescentes com maior superfície para precipitação do $\mathrm{Mn}$. D'Croz et al. (1989) observaram que R. mangle tem taxa de decomposição 
maior no Panamá que na região subtropical. Nos experimentos de Schmidt foi observado menor taxa de decomposição para $R$. mangle em comparação com outras espécies. A. schaueriana permaneceu com maior concentração de Fe em relação à biomassa e maior taxa de decomposição dentre as espécies.

Para a determinação da concentração de metais (Cu, $\mathrm{Cr}, \mathrm{Fe}, \mathrm{Mn}, \mathrm{Ni}, \mathrm{Pb}$ e Zn) e avaliação do grau de contaminação, vários autores empregam o fator de enriquecimento. O sedimento é considerado enriquecido para fatores maiores que 5, quando a concentração no sedimento é considerada como de origem antrópica. Para a quantificação do metal translocado para as folhas a partir do sedimento utiliza-se o fator de transferência (Oliveira et al., 1998). Em relação a este fator, o autor (op cit), observou que mesmo com concentrações relativamente elevadas no sedimento não houve translocação para as folhas ( $L$. racemosa), provavelmente devido aos mecanismos de exclusão (placas de Fe na rizosfera). A partir do pressuposto que o Manguezal é exportador de matéria orgânica e que esta se incorpora na cadeia alimentar, evidencia-se que os metais não estão sendo transferidos para o vegetal, consubstanciando a hipótese de que funcionam como barreiras geoquímicas à transferência de metais para as cadeias alimentares, retendo-os no solo (Silva et al., 1990).

Com relação à parte da planta onde há maior concentração de metais, o trabalho de Oliveira et al. (1998), demonstrou que na grande maioria dos casos a concentração de metais se deu na seqüência raízes > folhas > frutos, e nestes três constituintes estudados, a concentração se deu na seqüência Fe > $\mathrm{Mn}>\mathrm{Zn}>\mathrm{Cu}>\mathrm{Ni}>\mathrm{Pb}>\mathrm{Cr}$.

Walsh (1974) realizando testes com propágulos de R. mangle submetidos a diferentes concentrações de $\mathrm{Pb}, \mathrm{Cd}$ e $\mathrm{Hg}$ observaram que apenas $\mathrm{Cd}$ e $\mathrm{Hg}$ foram translocados para os propágulos. A sobrevivência dos propágulos foi afetada somente em concentrações de $500 \mu \mathrm{gHg} / \mathrm{solo}$. Os sintomas de envenenamento por $\mathrm{Hg}$ foram perda de turgor, epinastia, abscisão foliar, clorose e escurecimento das folhas e hastes. 
O Rio Cubatão contém as maiores concentrações de $\mathrm{Hg}$ na área da Baixada Santista e constitui o principal veículo poluidor do estuário. Como as condições físico-químicas do ambiente estuarino naturalmente são propensas à precipitação dos metais ( $\mathrm{pH}$ alcalino), em oposição à sua mobilidade ( $\mathrm{pH}$ ácido), as concentrações de $\mathrm{Hg}$ nos sedimentos tendem a ser maiores nas proximidades da fonte poluidora. Este Rio recebe a principal carga de efluentes industriais de Cubatão e lança águas poluídas nos tributários promovendo a dispersão do metal. Assim, as concentrações de Hg são relativamente elevadas nos rios Pedreira e Casqueiro, e os locais mais afastados como nos Rios Capivari, Cascalho e Morrão são menos afetados (Luiz-Silva, 2002).

As fontes de contaminação ambiental por metais-traço são diversas e entre estas figuram o chorume de lixões. Um traballho realtado por Masutti \& Pamitz (2000) descreve a situação do Manguezal de Itacorubi (FlorianópolisSC), instalado sobre área de Manguezal durante 34 anos, funcionando sem tratamento do chorume. Nesta situação foram avaliados os metais $\mathrm{Cd}, \mathrm{Cu}, \mathrm{Mn}$, $\mathrm{Ni}, \mathrm{Pb}$ no chorume percolado do aterro, na água intersticial, nos sedimentos, na S. alterniflora (gramínea), em um crustáceo e um molusco. O sedimento apresentou-se como maior reservatório de todos os metais estudados, com exceção de $\mathrm{Cd}$, o que reforça o papel do Manguezal como barreira biogeoquímica, com aprisionamento dos metais nos sedimentos sob forma não biodisponivel, o que justifica as baixas concentrações de metais na biota. Entre os compartimentos bióticos, S. alterniflora apresentou maiores concentrações de Cd e Cu e a água intersticial concentrações altas para os metais estudados.

Rodrigues \& Roquetti-Humaytá (1988) concluíram em seus experimentos, que os teores de metais ( $\mathrm{Cd}, \mathrm{Pb}, \mathrm{Cu}, \mathrm{Cr}, \mathrm{Hg}$ e $\mathrm{Zn}$ ) foram mais elevados em folhas de $A$. schaueriana e também as maiores variabilidades nas concentrações, ao passo que $R$. mangle e $L$. racemosa, consideradas plantas sal excludentes, evidenciaram menor acúmulo de metais, independentemente dos altos níveis registrados para o sedimento. 
Ramos \& Silva (1996) destacam a contribuição das folhas que caem das árvores na retenção de metais presentes na água do mar, pois estas são em parte levadas pela maré e entram na cadeia alimentar e em parte retidas na floresta e degradadas por fungos e bactérias, formando ambiente propício à redução com diminuição do teor de Oxigênio ou aumento do Hidrogênio nas substâncias, de forma que os compostos gerados contribuem para a retenção de metais. Harbison (1986) acrescenta que as condições anóxicas associadas à degradação bacteriana da matéria orgânica favorece a precipitação de sulfetos metálicos relativamente insolúveis nestas condições redox.

Para avaliar o compartimento de maior concentração de metais entre folhas e sedimentos tem-se o Fator de concentração (F) que é igual a concentração do metal na folha dividido pela concentração do metal no sedimento. Valores de $\mathrm{F}$ acima de 1 indicam que a planta concentra mais 0 metal do que o sedimento e inferiores a 1 indicam que a planta não acumula o metal em suas folhas, impedindo sua entrada ou controlando-a (Citron et al., $\mathrm{s} / \mathrm{d})$. Utilizando-se deste índice Citron e seus colaboradores concluiram que $R$. mangle dificulta a acumulação de metais como o $\mathrm{Pb}, \mathrm{Cr}$ total, $\mathrm{Hg}$, e em certo grau também de $\mathrm{Zn}$, mas pode concentrar $\mathrm{Cu}$ em suas folhas; a espécie $L$. racemosa concentra $\mathrm{Cu}$ e tem concentrações de $\mathrm{Zn}$ e $\mathrm{Cd}$ nas folhas similares as do sedimento e $A$. schaueriana concentra $\mathrm{Cd}, \mathrm{Zn}$ e $\mathrm{Cu}$ nas folhas em valores maiores que os encontrados no sedimento. Essa diferença no controle e na variabilidade das concentrações dos metais nas três espécies pode ser explicada pelas estratégias que possuem no controle de sal e que afeta também a absorção dos metais. As espécies filtradoras ( $R$. mangle) podem excluir os metais mantendo concentrações menores nos tecidos, ao contrário, as espécies excretoras ( $A$. schaueriana) que permitem a entrada de sais podem ter menor capacidade de excluir os metais dos tecidos. O conteúdo de metais no material foliar reflete os aportes dessas substâncias nas atividades antrópicas, porém pode refletir níveis naturais no ambiente, resultantes de características geoquímicas da região. 
Silva et al. (1990) descrevem um estudo sobre a contaminação de Fe, $\mathrm{Zn}, \mathrm{Mn}, \mathrm{Cu}, \mathrm{Cr}, \mathrm{Pb}$ e Cd em R. mangle na Baia de Sepetiba (RJ) onde os metais acumulam-se nos sedimentos (cerca de 99\%) e pequena parcela permanece na biomassa dos tecidos perenes (os metais estão nos sedimentos e não na forma biosolúvel para captação pelas plantas). A análise foi feita em folhas, troncos, caule, flores e partes aéreas e subterrâneas (raízes em diferentes profundidades). Nos sedimentos foi encontrada a seguinte ordem em relação à concentração: $\mathrm{Fe}>\mathrm{Mn}>\mathrm{Zn}>\mathrm{Cr}>\mathrm{Pb}>\mathrm{Cu}>\mathrm{Cd}$ a $50 \mathrm{~cm}$ de profundidade. Ramos e folhas apresentaram alta concentração de $\mathrm{Mn}$; raízes subterrâneas alta concentração de $\mathrm{Fe}$, Zn e Cu; frutas, folhas e flores baixa concentração de $\mathrm{Cu}$ (abaixo do nível de medição). Cr foi detectado em tecidos perenes (tronco e ramo). Pb e Cd ficaram abaixo do nível de detecção. Assim, os tecidos perenes são os principais captadores da maioria dos grupos de metais ( $\mathrm{Mn}, \mathrm{Fe}, \mathrm{Cu}, \mathrm{Cr}$ ) e os decíduos contêm porção não significativa destes. A curto prazo os metais estão nos sedimentos, mas ao longo prazo as plantas também atuam como reservatório, constituindo uma barreira para metais em áreas costeiras tropicais.

No mesmo local, ou seja, na Baía de Sepetiba (RJ), foi estudado a acumulação de metais ( $\mathrm{Cu}, \mathrm{Cr}, \mathrm{Cd}, \mathrm{Zn}, \mathrm{Mn}, \mathrm{Co}, \mathrm{Pb}, \mathrm{Ni}$ ) em sedimentos superficiais sob Manguezal e Banco de gramíneas, submetidos à poluição metálica. Os resultados mostraram que os sedimentos do Manguezal apresentaram concentrações mais altas para todos os metais, provavelmente em função do teor duas vezes superior de matéria orgânica, menor oxigenação e posição em relação a maré e ondas (Lacerda \& Abrão, 1984).

Já Duke \& Pinzón (1992) para esta região estudaram solos e água intersticial sob influência da rizosfera de árvores de Manguezal com R. mangle e A. schaueriana, de gramíneas de marismas (Spartina) e de áreas sem vegetação em planícies de lama, avaliando-se o $\mathrm{pH}$, potencial redox, salinidade, teor de matéria orgânica, concentração de sulfetos e concentrações totais e trocáveis de metais traço $(\mathrm{Fe}, \mathrm{Zn}, \mathrm{Cu}, \mathrm{Pb}$ e $\mathrm{Cd}$ ). Concluíram que a rizosfera das 
diferentes plantas apresentaram diferenças significativas em sua biogeoquímica. Os solos de planície de maré e sob Rhizophora são geralmente óxicos, com baixas concentrações de sulfetos. Metais traços também foram diferentes entre os diferentes solos, pois os de planície de maré apresentam as maiores concentrações de metais totais, seguindo-se os solos de Manguezal e por último os solos sob Spartina. Entretanto, as concentrações trocáveis de metais traço foram semelhantes para todos os solos, com exceção daqueles sob $A$. schaueriana, que devido a sua típica instabilidade de potencial redox, apresentou as maiores concentrações de metais trocáveis.

Lacerda \& Resende (1986) descrevem um estudo de metais em macrófitas, realizado também na Baía de Sepetiba, enfocando a acumulação e distribuição de metais em diferentes partes de plantas marinhas, uma vez que os trabalhos realizados tem mostrado que a acumulação de metais é maior nas raízes e influenciada pela densidade da raiz, idade, grau de contaminação da área e espécies de macrófitas. Os autores (op cit) estudaram a distribuição de $\mathrm{Zn}, \mathrm{Cu}, \mathrm{Mn}, \mathrm{Fe}$ e $\mathrm{Pb}$ em macrófitas e verificaram que somente para o $\mathrm{Pb}$ a concentração no sedimento apresentou valor moderadamente contaminate e os demais estiveram na faixa não-contaminante. No geral a concentração reflete a relativa abundância de metais no sedimento. A concentração de $\mathrm{Zn}$ e $\mathrm{Mn}$ apresentou padrão similar dentro da planta, nas folhas. Entretanto, enquanto a concentração de $Z n$ nas raízes e rizomas é similar, a concentração de $M n$ nos rizomas foi mais baixa. Fe e Cu apresentaram concentração alta nas raízes e mais baixa nos rizomas e folhas. O padrão de distribuição de $\mathrm{Pb}$ foi diferente de outros metais, com concentrações similares nas diferentes partes da planta. A concentração de Fe e Mn decresce com a idade em todas as partes da planta, enquanto $\mathrm{Pb}$ aumenta. A concentração de $\mathrm{Zn}$ aumenta nos rizomas e raízes mas permanece a mesma em folhas, enquanto a concentração de $\mathrm{Cu}$ aumenta nas folhas e rizomas e permanece a mesma nas raízes. O Zn e Mn apresentam-se em altas concentrações nas folhas, o que é corroborado pelos resultados dos autores (op cit) que apresentaram maior concentração nas 
folhas, indicando que o Zn não é translocado para as partes subterrâneas. Fe e $\mathrm{Cu}$ apresentam maior concentração nas raízes do que nas folhas ou rizomas. Macrófitas são conhecidas por suprir suas raízes com Oxigênio translocado das folhas e que é excretado nos sedimentos; isto afeta o Fe que pode se acumular no sedimento. Enquanto Fe apresenta baixa concentração em toda a planta no final da estação, o Cu aumenta nas folhas e rizomas devido à excreção e alta capacidade de translocação (independente da espécie), porém a direção do fluxo interno pode depender da espécie. O comportamento do $\mathrm{Pb}$ (alta concentração nas raízes) é devido a maior superfície de área, que aumenta a capacidade de absorção desse metal.

\subsection{Mortalidade em plantios de propágulos}

O estabelecimento da plântula é uma fase crítica de vida de qualquer planta, mas torna-se particularmente difícil para as plantas de Manguezal devido ao substrato instável e variável e à influência da maré. O grau de viviparidade, a localização dos tecidos de flutuação, o tamanho e, sobretudo, o peso do propágulo são fatores que determinam as condições de dispersão, estabelecimento e a taxa de sobrevivência das plântulas (CETESB, 1989).

Os primeiros relatos sobre os trabalhos de recuperação de Manguezais são da década de 70, quando se inicioram replantios nos EUA, Índia, Filipinas, Malásia e Porto Rico (Lewis III, 1982), utilizando-se especialmente a espécie $R$. mangle. O principal objetivo era verificar o potencial do emprego de determinadas espécies e testar técnicas de reprodução de mudas e propágulos, avaliando época, forma de plantio e práticas culturais.

Na Colômbia, Bohorquez \& Prada (1986) realizaram o transplante de 130 plântulas de R. mangle, em diferentes ilhas do litoral Caribenho, observando as taxas de crescimento e o número médio de folhas por indivíduo. A maior taxa de sobrevivência encontrada foi de $34,8 \%$, e o período de maior crescimento e produção de folhas foi quando as chuvas começaram. 
$\mathrm{Na}$ Índia, a partir de 1985, iniciou-se um programa de restauração de Manguezais na costa centro oeste, sendo utilizadas R. mucronata, A. officinalis, Kandelia candel e Soneratia alba. A taxa de sobrevivência para R. mucronata e A. officinalis variou de 20 a 90\%, dependendo do método empregado (Untawale citado por Menezes, 1994).

Foram realizados estudos de regeneração de $R$. apiculata e $R$. mucronata no Manguezal de Pitchavaram, Tamil Nadu. Propágulos foram coletados das matrizes em agosto e outubro, examinados (com aproveitamento dos que não estavam predados ou infectados) e plantados no substrato de lodo, tanto na beira quanto no canal. No canal o plantio foi feito com vasos de barro com lama macia, enterrados acima da marca da maré baixa e removidos após 2 semanas. Após cerca de 12 meses a sobrevivência na beira foi de 65,9\% e no canal de $47,4 \%$ devido ao melhor desenvolvimento dos propágulos de vasos que fixaram a plântula e preveniram distúrbios e quanto ao crescimento, as plântulas nos vasos tiveram uma média de altura maior que as plantadas diretamente. Em outro estudo semelhante, realizado no sul do estuário de Adayar, os resultados mostraram somente $9,35 \%$ de sobrevivência da Rhizophora após 4 meses do plantio (Sekar et al., 1989).

Field (1998) descreve que a seleção de locais para plantio deve considerar a quantidade e qualidade da água e o tempo de permanência desta na área, pois é vital que plantas jovens sejam inundadas regularmente, mas não em grande grau, pois morrem. Na Tailândia foi verificado que uma infestação por craca retardou o crescimento de plântulas e muitas morreram.

Orge (1997) comparou fixação, altura, número de folhas, ramos laterais entre outros parâmetros de propágulos de $R$. mangle plantados em áreas com e sem influência de atividades petroleiras, durante o período de fevereiro de 1994 a dezembro de 1995, na Baía de Todos os Santos (BA). Os maiores e menores valores encontrados para a taxa de sobrevivência após 21 meses do plantio foram de 61 e $0 \%$ e para altura média foram de 70 e $35 \mathrm{~cm}$. 
Abraão (1998) utilizou diferentes metodologias de plantio de espécies de Manguezal em uma área de aterro hidráulico na Ilha de Santa Catarina (SC). Entre os resultados destaca-se: $100 \%$ das mudas $A$. schaueriana e $R$. mangle morreram e 42\% das mudas de L. racemosa sobreviveram após 100 meses do transplante; a melhor taxa de sobrevivência para os propágulos de $A$. schaueriana em viveiro foi de $82 \%$, obtida para mudas em substrato de composto orgânico e areia de praia; a maior sobrevivência dos propágulos transplantados foi de $10 \%$ após 100 dias, plantados com proteção artificial; para Spartina alterniflora não houve mortalidade de forma que o plantio da espécie é a melhor opção para o local devido ao baixo custo e alta taxa de sobrevivência.

No trabalho de Moscatelli \& Almeida (1994) realizado em Manguezais no município de Angra dos Reis (RJ) foram apresentados resultados referentes à mortalidade e crescimento de acordo com a disposição das mudas, o grau de exposição ao mar e diferenciações estruturais associadas ao período de plantio, espaçamento e manejo de mudas arbóreas da espécie R. mangle. Algumas tendências no posicionamento das plântulas demonstram que o grau de exposição aos movimentos de maré com arraste de resíduos sólidos podem influenciar a sobrevivência e crescimento, uma vez que as fileiras de plantio frontais, expostas aos movimentos de maré e situadas em um nível mais baixo em relação às fileiras posteriores, apresentaram número inferior de mudas. Foi observado também que a variação microtopográfica, tanto perpendicular como paralela à variação da maré, age como fator de interferência na sobrevivência das mudas. Com relação ao espaçamento, as mudas no espaçamento original foram influenciadas pela competição por espaço e luz e as mudas com espaçamento ampliado devido à remoção de suas "vizinhas" apresentaram um investimento energético desviado à produção de raízes escoras e incremento de diâmetro, extensão lateral dos ramos e diminuição da altura. Já as mudas submetidas ao tratamento de repique, apesar de livres da competição por espaço e luz, permaneceram com valores intermediários entre os tratamentos, como conseqüência do processo de estresse característico do repique. 
Segundo Paludo \& Klonowski (1999), no trabalho feito na Barra de Mamanguape (PB), o plantio direto de propágulos de $R$. mangle, $L$. racemosa e A. schaweriana foi comparado em áreas úmidas e mais secas. Os propágulos de $R$. mangle se desenvolveram melhor e apresentaram folhas mais rápido em solos mais secos do que em inundados, porém neste último as mudas se estabeleceram em maior número, mais vigorosas e com maior taxa de sobrevivência. A baixa taxa de sobrevivência das mudas ( $7 \%$ depois de dois anos) teve como causa a predação por caranguejos e o ressecamento dos propágulos em áreas pouco irrigadas. Os maiores valores de altura e diâmetro médio foram obtidos em terrenos molhados, alcançando até 2,5 vezes o tamanho das mudas de terrenos secos e estas apresentaram raízes escora mais cedo. Para as espécies $L$. racemosa e $A$. schaweriana o maior desenvolvimento ocorreu nos terrenos secos.

Rabinowitz (1978b) estudou a mortalidade e tamanho inicial de propágulos em espécies de Manguezal (Pelliciera rhizophorae, Avicennia bicolor, A. germinans, L. racemosa e R. mangle). Para L. racemosa, 50\% dos propágulos desapareceram após 45 dias; $P$. rhizophorae cresce de 32 a $83 \mathrm{~cm} /$ ano e a largura da folha aumenta de 8 a $30 \mathrm{~cm}^{2} ; R$. mangle permanece entre 34 e $36 \mathrm{~cm}$ de altura todo o ano e a média da área da folha declina. Embora o padrão de mortalidade de $P$. rhizophorae e $R$. mangle sejam similares, o padrão de crescimento é diferente, plântulas da primeira produzem muitos nódulos e folhas que aumentam até uma taxa constante e da segunda produzem nódulos lentamente e o número de folhas por planta declina durante a estação seca do ano. Plântulas que crescem de pequenos propágulos (1g ou menos de peso fresco) tem alta taxa de mortalidade, o que sugere que a assimilação fotossintética está sendo ultrapassada pela respiração com morte das plântulas por gradual exaustão das reservas embrionárias. A população de plântulas de propágulos menores ( $A$. germinans e $L$. racemosa) retornam anualmente e aqueles com grandes populações ( $P$. rhizophorae e $R$. mangle) permanecem embaixo do dossel. Assim, a colonização da $L$. racemosa dá-se 
com chão forrado de plântulas de outubro a fevereiro e escassez durante o resto do ano; plântulas de $R$. mangle e $P$. rhizophorae são vistas durante todo o ano, $R$. mangle aparecem em clareiras e $P$. rhizophorae crescem na sombra alcançando lentamente o dossel. Com estes resultados conclui-se que o aparecimento de clareiras é importante para A. germinans e L. racemosa e pode ser mais crítico na reposição de $R$. mangle do que de $P$. rhizophorae.

Davis (1940) observou que a ausência de luz solar pode retardar o crescimento ou até matar as plântulas. Em estudos realizados em manguezais da Flórida constatou para plântulas recém fixadas uma mortalidade de até 100\% após quatro meses, que teria ocorrido em função da exaustão das reservas do embrião por uma relação desfavorável entre fotossíntese e respiração, sendo as manchas de sol que atingem o chão do Manguezal importantes para o estabelecimento das plântulas. Notou ainda a existência de uma correlação entre o peso do propágulo e a taxa de mortalidade da espécie: a medida em que o peso diminui a mortalidade aumenta na seguinte seqüência: $R$. mangle, $A$. germinans e L. racemosa.

Estudos comparando técnicas de transplante de espécies de Manguezal: $R$. mangle, $L$. racemosa e $A$. germinans foram avaliados com base na taxa de sobrevivência e crescimento como indicadores de sucesso. Observou-se que $L$. racemosa atingiu maior crescimento, porém sofreu mais com temperaturas baixas, seguida da $R$. mangle que suporta imersão em grandes profundidades e por último a $A$. germinans com crescimento mais lento, mas tolerância ao frio. Assim, a $L$. racemosa prefere substrato seco e $A$. germinans salinidades mais altas, e com relação à captura de detritos, $A$. germinans e $R$. mangle possuem sistemas mais eficientes de raízes aéreas (FEEMA, 1979). 
Menezes et al. (1994), estudando Manguezais de Cubatão, objetivaram estabelecer uma base metodológica para o plantio de $R$. mangle e verificar a viabilidade desta espécie na recuperação de Manguezais, pois naturalmente a espécie já apresenta expressiva capacidade de regeneração na região, sendo dominante e estabelecendo-se na maioria das áreas fortemente degradadas. Testaram a influência dos seguintes fatores no sucesso do plantio: estágio de desenvolvimento (propágulo e plântula), tipo de sedimento (mais ou menos consolidado) e necessidade do emprego de fixadores artificiais (estacas) para evitar o arraste de mudas pela maré. Os resultados obtidos mostram que os Manguezais de Cubatão são passíveis de recuperação; que é importante realizar o replantio em maré baixa, na ausência d'água sobre o substrato; que as plântulas sofreram estresse nos dois primeiros meses devido ao plantio, refletindo em pequeno crescimento e redução do número médio das folhas (comportamento não observado nas plântulas-controle); a presença ou não de fixadores, assim como o tipo de sedimento não influi no estabelecimento e crescimento das plântulas; o plantio de propágulos apresentou taxas de mortalidade iguais ou menores às plântulas e valores médios de altura e número de folhas próximos aos das plântulas, indicando que além de serem mais fáceis de coletar, transportar e plantar, em pequeno período de tempo apresentam resultados de crescimento similares aos das plântulas.

Estudos realizados em Cubatão, compararam o desenvolvimento de propágulos de $L$. racemosa de um lote plantado diretamente e outro plantado em estufa (vasos com substrato de Manguezal), sendo as plântulas transferidas para o campo após três meses. A germinação e sobrevivência dos propágulos em estufa foi de $7 \%$ enquanto que o plantio direto no Manguezal foi de $0 \%$. A transferência das plântulas para o Manguezal foi feita quando estas apresentavam altura de $5,1 \mathrm{~cm}$ e a taxa de sobrevivência foi de $86,4 \% \mathrm{com}$ crescimento acelerado, atingindo uma altura média de $110 \mathrm{~cm}$ após 20 meses. A baixa taxa de germinação na estufa pode ser devida a condições inadequadas desta; tipo de sedimento empregado; uso de propágulos com e sem radícula e 
posição dos propágulos sob ou sobre o sedimento. Assim, os autores recomendam um período de crescimento das mudas em estufa em vez de plantio direto no Manguezal (Menezes et al., 1997).

Menezes (1999) testou a viabilidade da recuperação dos Manguezais em Cubatão utilizando o plantio de propágulos e o transplante de plântulas de $R$. mangle com e sem estaca, tendo obtido os seguintes resultados: nas plântulas transplantadas houve maior decréscimo no número inicial de folhas; a altura, número de folhas, gemas, ramificações e rizóforos para as plântulas sob o dossel foi menor do que para plântulas de áreas completamente descampadas e, portanto, com incidência solar uniforme e sem competição com árvores maiores. As plântulas com ou sem estacas foram consideradas iguais entre si. Observou-se que as diferenças na granulometria do sedimento influenciaram o desenvolvimento das plântulas e dos propágulos, sendo que locais com maior percentual de silte e argila foram mais propícios ao desenvolvimento de $R$. mangle. Observou-se ainda que a taxa de mortalidade e pequeno desenvolvimento (baixo número de folhas, gemas e ramificações) das plântulas pode estar relacionado ao nível mais baixo do terreno (maior tempo de imersão e sedimentos de menor granulometria), que apresentam menor energia e demandam mais tempo para a remoção e/ou degradação natural dos contaminantes (esgoto) do sedimento maior. Notou-se o decréscimo na altura e número médio de folhas para as plântulas transplantadas, o que é devido provavelmente ao assentamento das plântulas ao terreno. A fixação, sobrevivência e desenvolvimento dos indivíduos $R$. mangle acabaram facilitando a fixação e desenvolvimento de outros propágulos, tanto de $R$. mangle como de outras espécies, efeito este também citado por Macnae (1968) para outras espécies de Manguezal. O plantio de propágulos e transplante de plântulas resultou em comprimentos médios de $78,7 \mathrm{~cm}$ e $85,4 \mathrm{~cm}$, após 748 dias, o que significa um incremento de comprimento respectivo de 4,9 e 2,0. 
Os resultados do trabalho de Eysink et al. (1998a) na região da Baixada Santista mostraram que os propágulos de $R$. mangle mantidos em condições úmidas, plantados 14 dias após a colheita, apresentaram taxa de crescimento, após 294 dias, de até 2,98 vezes, resultado este bastante similar à taxa encontrada por Menezes et al. (1996) que foi de 3,4 vezes. Nestas condições obteve-se uma média de 22,7 folhas e uma taxa de sobrevivência de 98\%, superando as encontradas por Menezes que foram de 17 e 75\%. Assim, a viabilidade da manutenção de propágulos em estufa em condições úmidas, por cerca de 80 dias, apresentou taxa de sobrevivência que varia de 80 a 98\% após 294 dias de monitoramento, embora se tenha observado a desvantagem do desenvolvimento de raízes, dificultando o plantio dos propágulos e as vezes a ocorrência de apodrecimento da coifa. Quando acondicionados por mais de 133 dias a taxa de sobrevivência cai para 14\%. Em relação aos propágulos mantidos em condições secas, embora não tenham desenvolvido raízes, não devem ser armazenados por mais de 40 dias, quando apresentam taxa de sobrevivência de $77 \%$ após 252 dias e quando mantidos secos por mais de 76 dias têm uma redução na taxa de sobrevivência para 29\%, e por fim, se mantidos por mais de 130 dias, a taxa cai para zero. 


\section{3 - METODOLOGIA}

\subsection{Passos metodológicos}

Os passos metodológicos do trabalho são a seguir sintetizados:

- Levantamento de dados secundários: oriundos de material bibliográfico, cartográfico e aerofotográfico (incluindo fotointerpretação digital).

- Seleção das áreas de amostragem: três áreas na Baixada Santista e uma na Ilha do Cardoso, empregando-se critérios específicos, fotointerpretação e visitas de reconhecimento na região.

- Coleta e preparação dos propágulos: coletas realizadas nas quatro áreas de amostragem e em seguida mensuração e preparação de lotes de propágulos para plantio, secagem e análises químicas.

- Demarcação das unidades de amostragem e mensurações: demarcação de 2 parcelas de árvores matrizes/área, 1 parcela de inventário florestal/área e 1 parcela de plantio/área, com subseqüentes mensurações em 4 campanhas de campo (semestrais) para as áreas da Baixada Santista e 2 para a Ilha do Cardoso (2 anos - no início e final das avaliações).

- Coleta e análises químicas de material botânico: amostras de folhas das árvores matrizes e de mudas do plantio e da regeneração natural foram coletadas na última avaliação, nas quatro áreas; em seguida fez-se as mensurações do material coletado e envio para laboratório de análises químicas (concentração de metais pesados). 
- Coleta e análises químicas de solo: amostras de solo foram coletadas nas quatro áreas para análises químicas (concentração de metais pesados e outros parâmetros).

- Análises estatísticas: compilação dos dados em planilhas eletrônicas e análises empregando o programa SAS - Statistical Analysis System.

- Coleta e identificação de praga: lagartas foram encontradas, casualmente, em uma mancha de Manguezal da Baixada Santista bastante danificada; exemplares vivos foram coletados e mantidos até a obtenção de mariposas para identificação da espécie.

- Discussão dos resultados e conclusões: a avaliação dos resultados foi voltada para elucidação da hipótese da influência da contaminação por metais pesados no estabelecimento dos indivíduos de Rhizophora mangle nos Manguezais da Baixada Santista, sendo feita a avaliação da qualidade ambiental.

A Figura 1 ilustra os passos metodológicos empregados, detalhando a metodologia e seqüência das ações em cada linha do trabalho. 


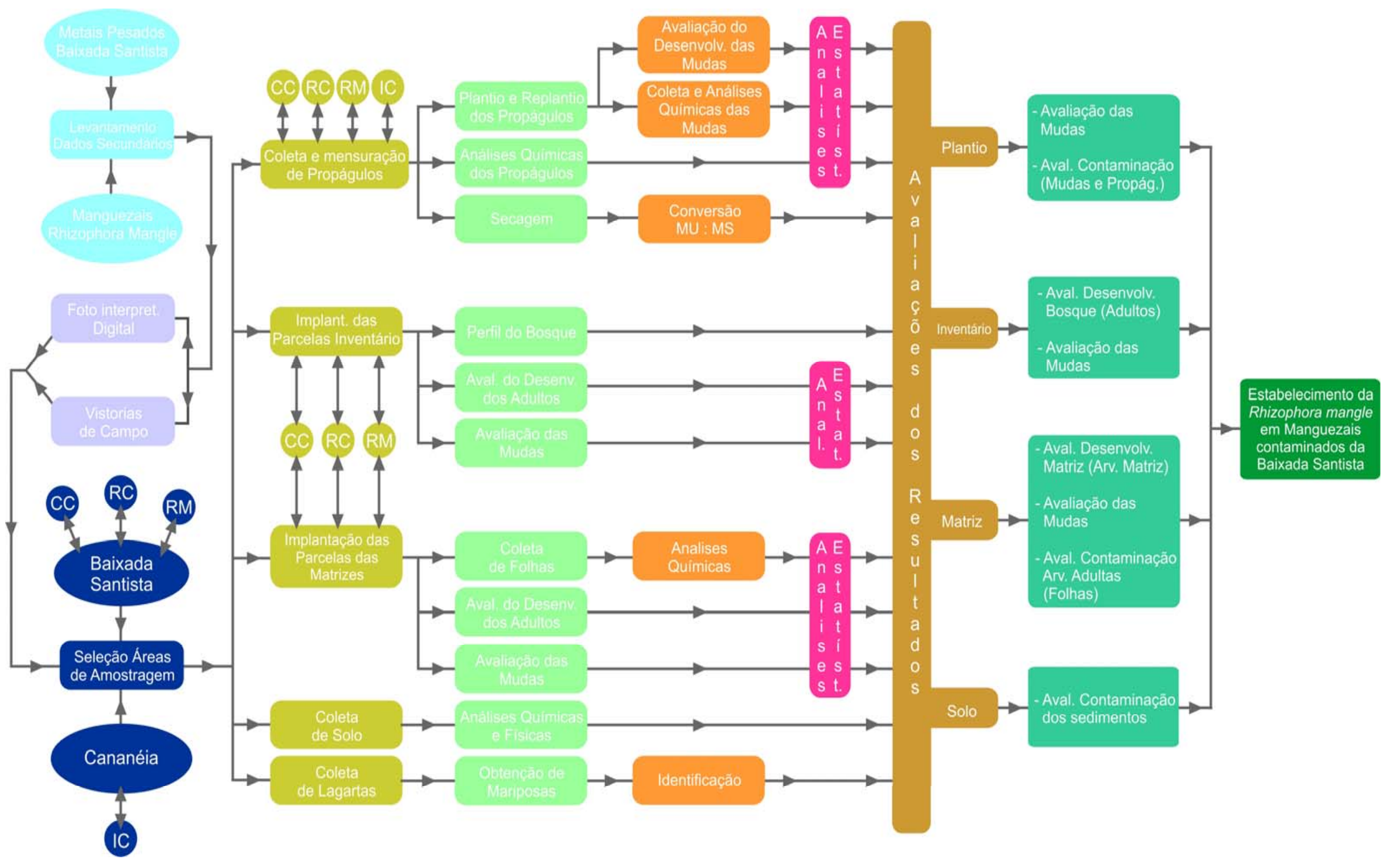

Figura 1 - Croqui ilustrativo dos passos metodológicos e seqüência de desenvolvimento do trabalho 


\subsection{Detalhamento da metodologia}

- Levantamento de dados secundários

Foram levantados dados bibliográficos e cartográficos para conhecimento das características e situação regional.

Cartas temáticas:

- IBGE, 1984: Folha Santos SF.23-Y-D-IV-3/SG.23-V-B-I-1 - escala 1:50.000.

- Mapeamento da Vegetação Natural do Estado de São Paulo (SMA), 1989:

Folhas: Cananéia SG.23-V-C-I-1 e Ariri SG.22-X-D-III-2 - escala 1:50.000. Aerofotografias:

- BASE, esc. Aprox. 1:10.000 - Ilha do Cardoso vôo de Nov./2000 e Rio Mariana, Canal da Cosipa e Rio Cascalho, vôo de Jan./2001.

\section{- Seleção da espécie para o estudo}

Com o enfoque da avaliação da interferência da contaminação de metais pesados sobre o estabelecimento do Manguezal, a espécie Mangue vermelho (Rhizophora mangle) foi selecionada baseado nos seguintes aspectos:

- Localização dos indivíduos da espécie no Manguezal - coloniza a faixa mais próxima dos cursos d’água, estando sujeita a maior contato com águas contaminadas.

- Estratégia de dispersão da espécie - propágulos com longo período de viabilidade e flutuação, favorecendo o contato com águas contaminadas.

- Área de colonização - A espécie se dispersa mundialmente, colonizando locais contaminados por metais pesados; os resultados obtidos podem ser comparados a outros de áreas com problemáticas similares. 


\section{- Caracterização da região sob estudo}

Baixada Santista

- Localização

A região da Baixada Santista localiza-se na porção central do litoral do Estado de São Paulo, na costa sudeste brasileira, entre as coordenadas $045^{\circ} 45^{\prime} \mathrm{W}$ e $046^{\circ} 45^{\prime} \mathrm{W}$ e $23^{\circ} 40^{\prime} \mathrm{S}$ e $24^{\circ} 06^{\prime} \mathrm{S}$ e compreende a área da escarpa da Serra do Mar, planície sedimentar até o mar, entre os rios Mongaguá e Itapanhaú (Bertioga), ocupando uma área de 51.500 ha, com 10.800 ha ocupados por Manguezais (Cintrón et al., s/d).

Menezes (1999) destaca que esta região inclui o Estuário de Santos e abrange as bacias dos rios Aguapeú, Branco, Piaçabuçu, Cubatão, Mogi, Quilombo, Jurubatuba, Diana e Itapanhaú, que nascem no interior da floresta pluvial tropical que recobre a Serra do Mar e o Planalto e deságuam no Estuário de Santos, após percorrer áreas da planície litorânea e Manguezais.

A definição da CETESB (1977) para a zona de Manguezais da Baixada Santista é a área que vai do pé da Serra do Mar até a llha de São Vicente, compreendendo os municípios de São Vicente, Cubatão, Guarujá e Santos.

A Figura 2 ilustra a área referida e os principais cursos d’água. 


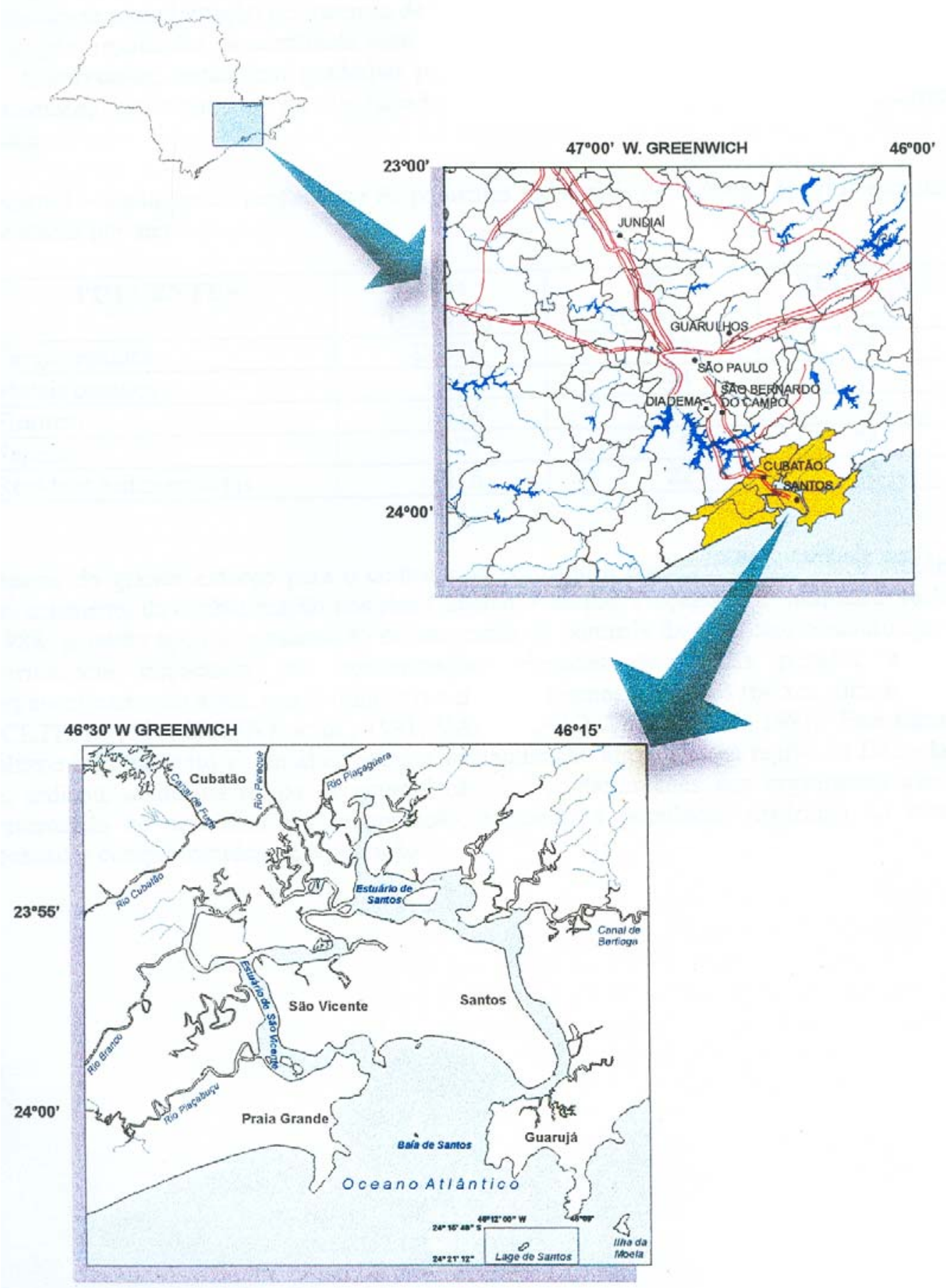

Figura 2 - Região da Baixada Santista inserida no litoral paulista, destacando os principais cursos d'água

Fonte: CETESB (2001a). 
- Clima

O clima da região da Baixada Santista caracteriza-se como tropical chuvoso ou litorâneo quente e úmido, com temperatura média anual superior a $20^{\circ} \mathrm{C}$ (durante o verão de outono a março, as temperaturas médias alcançam $25^{\circ} \mathrm{C}$ e no inverno, de maio a setembro, $19^{\circ} \mathrm{C}$ ) e pluviosidade elevada, variando entre 2.000 a $2.500 \mathrm{~mm}$ (pluviosidade e temperatura mais elevadas no período de janeiro e março - verão, diminuindo nos meses de junho a agosto - inverno), mas sem estação seca definida. Menezes (1994) ressalta valores de precipitação média anual entre 2.000 a 4.000 mm, variando de um local a outro devido ao efeito orográfico, com zonas mais chuvosas na borda da Escarpa da Serra do Mar (pluviosidade média de $4.000 \mathrm{~mm}$ ), e índices pluviométricos menores observados nas áreas expostas da planície litorânea.

A circulação atmosférica é dominada pela brisa marítima local e pela circulação geral e superior, definida pelas massas de ar tropical atlântica e polar. Nas escarpas da Serra do Mar e proximidades predominam dois fluxos de ventos: nordeste, no período noturno, e sudeste, durante o dia. As menores velocidades de ventos ocorrem no verão e as maiores nos meses de inverno, atingindo valores máximos entre 13 e $15 \mathrm{~h}$ e decrescendo após as $19 \mathrm{~h}$, comportamento que tem grande importância na dispersão de poluentes atmosféricos das indústrias instaladas nas escarpas (Menezes, 1994).

- Marés

A maré na região é do tipo misto, principalmente semidiurna, com amplitude média de 1,2m, amplitude de maré de sizígia de 1,4m e amplitude de quadratura de $0,9 \mathrm{~m}$; as marés na região atingem altura máxima de $1,6 \mathrm{~m}$ acima do nível médio que é de $0,7 \mathrm{~m}$. 


\section{- Geomorfologia}

A Baixada Santista apresenta grande diversidade geomorfológica com praias arenosas, terraços marinhos e planícies dominadas pela influência das marés. Possui um complexo sistema meândrico flúvio-estuarino com morros isolados na planície ou voltados diretamente para o mar. Essa diversidade é responsável tanto pelo contato entre os ambientes continental e marinho como pela existência da grande diversidade de ecossistemas (Menezes, 1999).

A área de Manguezal no Estuário de Santos se estabeleceu nos deltas coalescentes de vários rios que drenam as vertentes da Serra do Mar e ao longo do curso de canais que desembocam no mar. O carreamento de sedimentos é considerável devido à alta precipitação, ao intenso intemperismo, às altas escarpas e à característica torrencial dos rios ao longo de grande parte de seus cursos (Cintrón et al., s/d).

A margem continental ao longo da parte sudeste do litoral brasileiro é caracterizada pela presença da bacia sedimentar de Santos (Bacia de Santos), constituída por depressão tectônica meso-cenozóica preenchida por depósitos sedimentares e derrames basálticos. Os Manguezais dessa região encontramse sobre planícies essencialmente formadas por depósitos marinhos ou flúviolagunares quaternários (Novelli et al., 1994). É composto por uma espessa camada de argila marinha mole e cinza, com capacidade de suporte extremamente baixa e sujeita a intensa ação das marés (CETESB, 1977).

- Cobertura vegetal

A cobertura vegetal da região da Baixada é classificada fitoecologicamente como Floresta Ombrófila Densa, com áreas de formações pioneiras de influência fluviomarinha arbóreas-Manguezal e vegetação secundária sem palmeiras (Projeto RADAM Brasil, 1983, Folha SF.23/24 - Rio de Janeiro/Vitória, escala 1:1.000.000). 
Condicionada pela sua localização geográfica e características, a região pertence ao domínio da Mata Atlântica, formação vegetal intimamente relacionada ao relevo e pluviosidade, que apresenta grande variedade de formas e habitats, incluindo as Matas de planície litorânea (extensões geralmente limitadas pelas serras); Matas de encosta (nas vertentes orientais das serras do sul e sudeste); Matas de altitude (escarpa em torno de $1.100 \mathrm{~m}$ ); e os ecossistemas associados: Campos de altitude, Brejos interioranos, Encraves florestais do nordeste, Manguezais e Restingas. Os dois últimos tipos aparecem ao longo da costa recebendo influência direta do mar e dos ventos litorâneos, apresentando adaptações para o ambiente de alta salinidade.

Para a região sob enfoque, conforme pode ser observado na Figura 3 que apresenta o mapa da cobertura vegetal do Estado de São Paulo, observase que ainda existem áreas cuja cobertura vegetal varia de Mata à Capoeira e extensas formações associadas de Restinga e Manguezal entremeadas à áreas com diferentes intensidades de ocupação, porém as pressões sobre os remanescentes é intensa. 


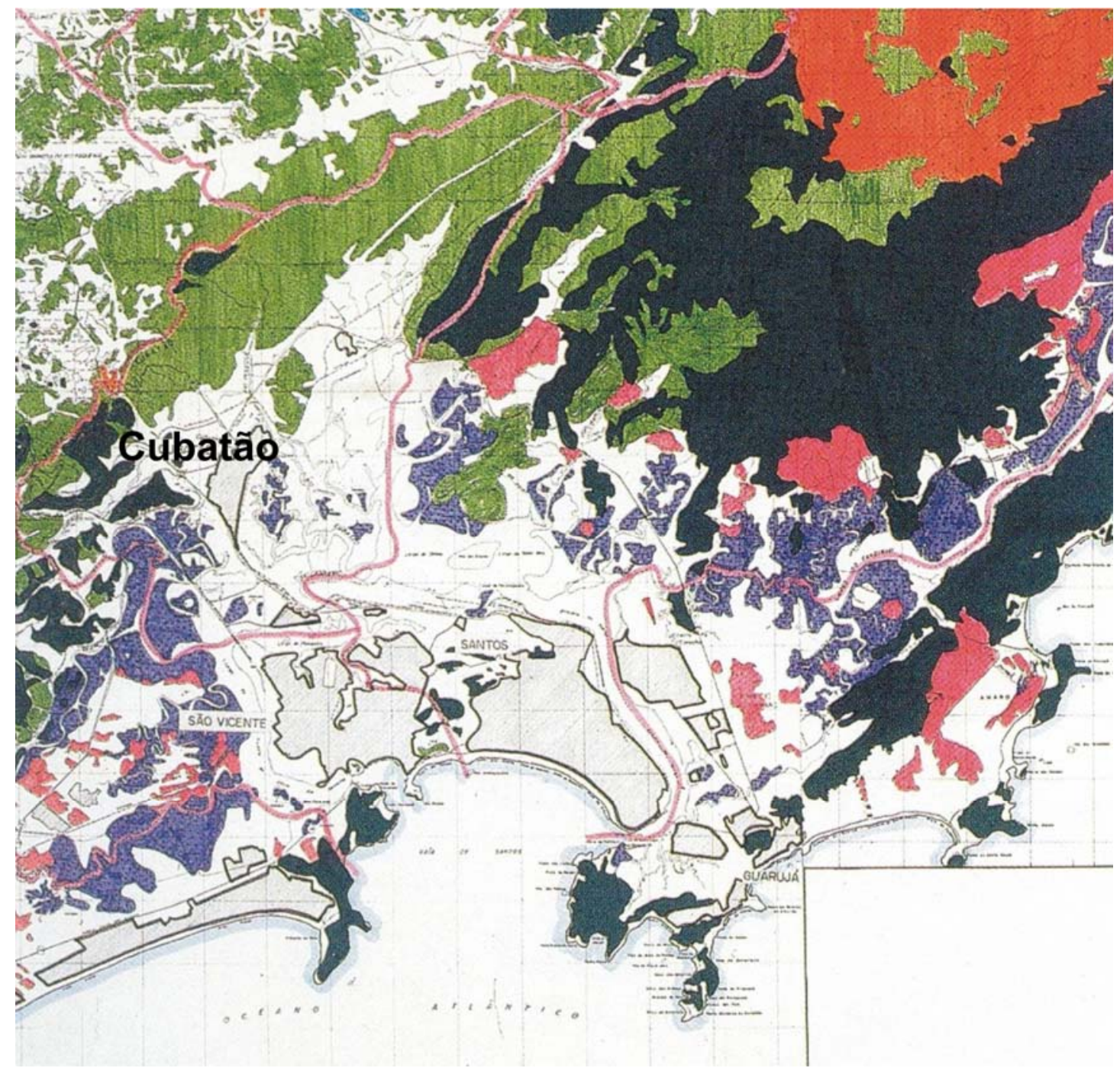

LEGENDA

CONVENÇÖES

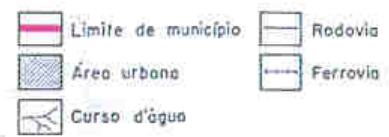

COBERTURA VEGETAL NATURAL

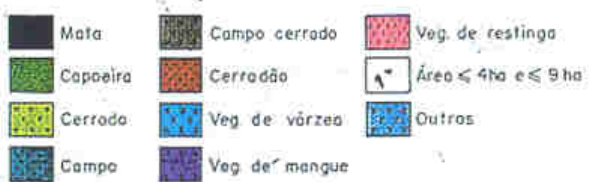

PEFLORESTAMENTO

Eucalipto
$\therefore$ Pinus
$\therefore$ Outros

Figura 3 - Cobertura vegetal da região onde se insere a Baixada Santista (Composição das Figuras 73, 79 e 80)

Fonte: IF/SMA. Inventário Florestal do Estado de São Paulo, 1993 (escala 1:250.000). 
Ressalta-se o histórico de ocupação regional exerce influência direta sobre a cobertura vegetal, transformada pela ação humana, principalmente devido à atividades agrícolas e extrativistas, ao desenvolvimento urbano e expansão das atividades portuárias e industriais (Silva et al, 1994).

Considerando-se os tipos fisiográficos de Manguezais descritos por Rodrigues et al. (1989), os bosques da região da Baixada Santista são na maioria classificados como tipo ribeirinho, desenvolvendo-se ao longo das margens dos rios com fluxo de água intenso e rico em nutrientes, fatores que induzem a um alto grau de desenvolvimento da vegetação.

- Fontes de poluição

Segundo dados da CETESB, apenas 40\% dos Manguezais dessa região encontram-se em bom estado de conservação (Silva et al., 1994). A degradação dos Manguezais do Estuário de Santos está associada aos derramamentos de óleo e a influência das águas dos Rios Cubatão e Mogi, cuja qualidade é bastante comprometida pelo lançamento dos efluentes do complexo urbano-industrial de Cubatão e pelas águas da Represa Billings, via Usina Henry Borden (Menezes, 1999). Dentre as áreas da Baixada Santista, a de Cubatão é a mais degradada, onde apenas $17 \%$ dos $29 \mathrm{~km}^{2}$ de Manguezais originais encontram-se em estado saudável (Silva et al., 1991).

Os poluentes encontrados na região são compostos industriais, portuários e domésticos. As fontes poluentes potenciais são representadas por mais de 10 grandes indústrias, 12 terminais portuários, além do Aterro Sanitário de Cubatão e do Guarujá e Lixões de Santos, São Vicente, Praia Grande e de Pilões (este último possui disposição conjunta de resíduos industriais perigosos (CETESB, 2001a). As Figuras 4 e 5 ilustram a situação da área em relação às fontes potenciais poluentes. 


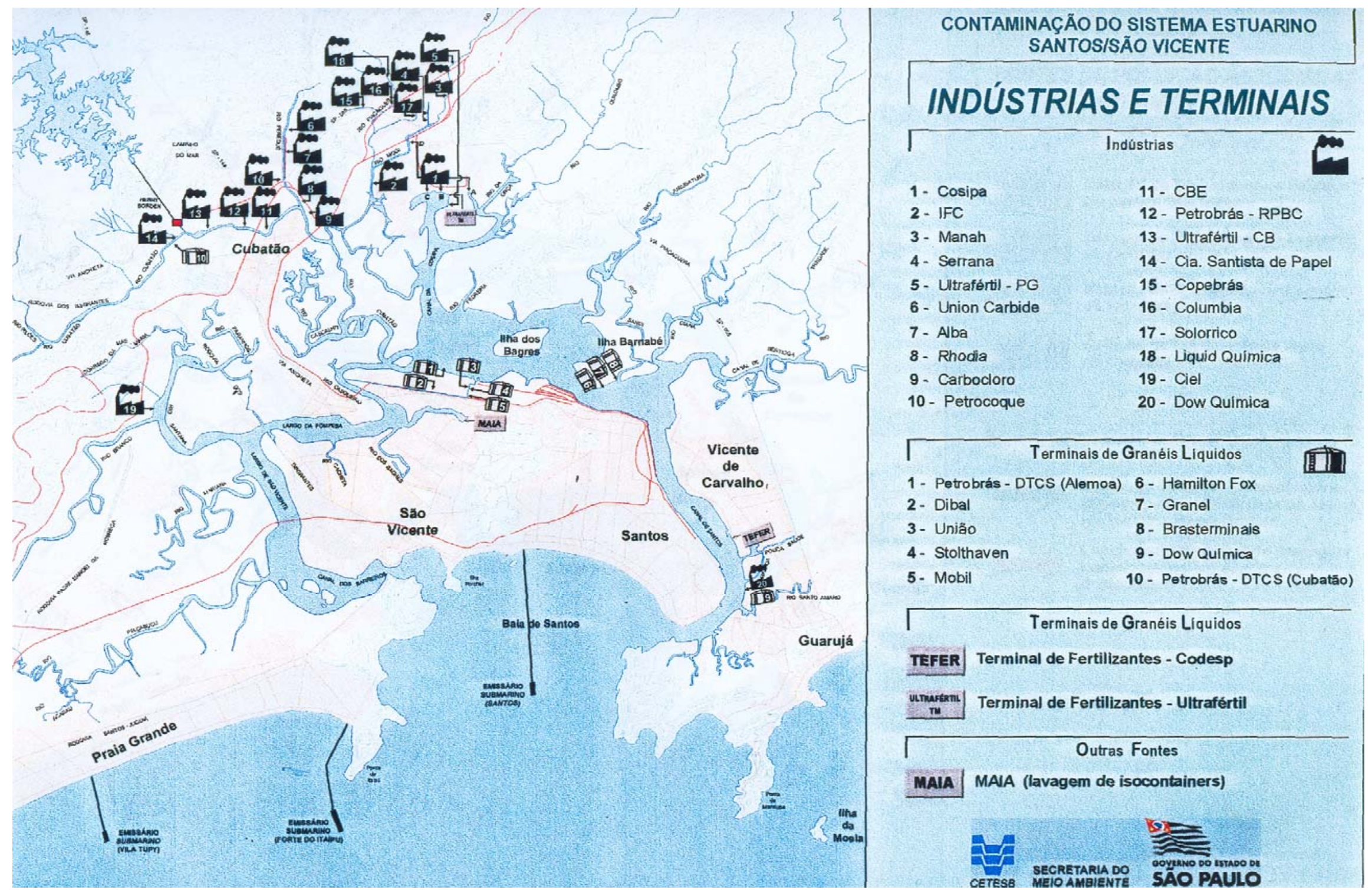

Figura 4 - Fontes potenciais de poluentes industriais e terminais portuários na região na Baixada Santista Fonte: CETESB (2001a). 


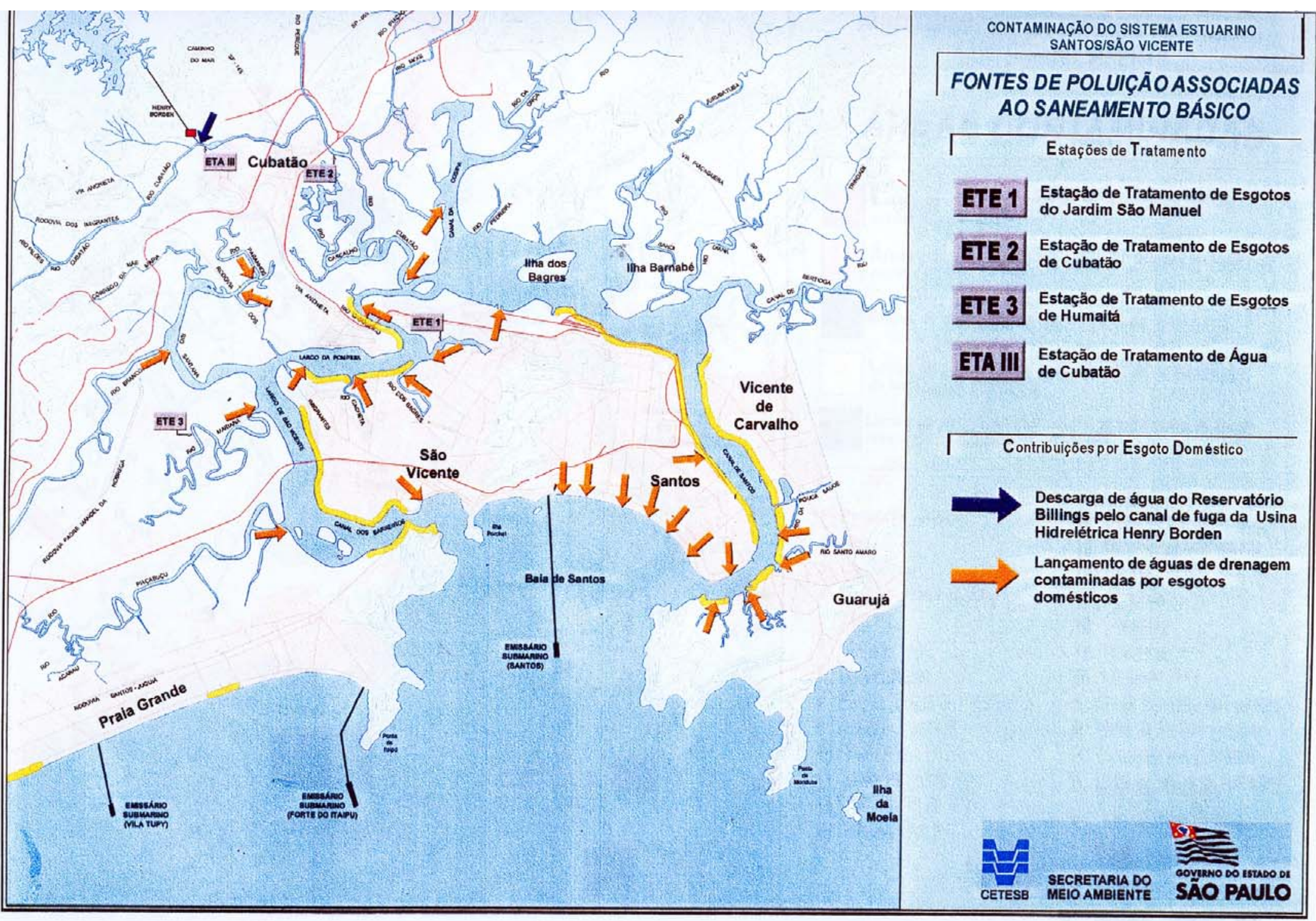

Figura 5 - Fontes potenciais de poluentes associadas ao saneamento básico na região da Baixada Santista Fonte: CETESB (2001a). Illha do Cardoso - Área Testemunha 
- Localização

A Ilha do Cardoso localiza-se no município de Cananéia $\left(25^{\circ} 04^{\prime} S\right.$ e $25^{\circ} 20^{\prime} \mathrm{S}$ e $47^{\circ} 53^{\prime} \mathrm{W}$ e $\left.48^{\circ} 06^{\prime} \mathrm{W}\right)$. Insere-se centralmente no Complexo Estuarino-Lagunar de Iguape-Cananéia - Paranaguá. Possui área de 14.054 ha, e desde 1962 é Parque Estadual da Ilha do Cardoso (Decreto Estadual $N^{\circ}$ 40.319/62). A Figura 6 destaca a região em que se insere a Ilha do Cardoso.

- Clima e Maré

O litoral sul do Estado de São Paulo apresenta clima sempre úmido. A temperatura média é $21,2^{\circ} \mathrm{C}$ (média-máxima $=24,9^{\circ} \mathrm{C}$; médiamínima $\left.=17,8^{\circ} \mathrm{C}\right)$. As médias anuais de temperatura, unidade relativa do ar, evaporação e precipitação são respectivamente: $23,8^{\circ} \mathrm{C} ; 88 \%$; $127,4 \mathrm{~mm}$ e $2.269 \mathrm{~mm}$.

A região estuarino-lagunar apresenta nível médio das marés de 0,80m e maré mínima de $0,0 \mathrm{~m}$ e máxima de $1,7 \mathrm{~m}$.

- Geomorfologia

A Ilha do Cardoso localiza-se na planície sedimentar litorânea de Cananéia-Iguape, separada do continente por um canal natural, Canal de Ararapira, sendo formada, principalmente, por rochas pré-cambrianas com depósitos quartenários na periferia.

- Cobertura vegetal

A Figura 7 apresenta a cobertura vegetal da região. 


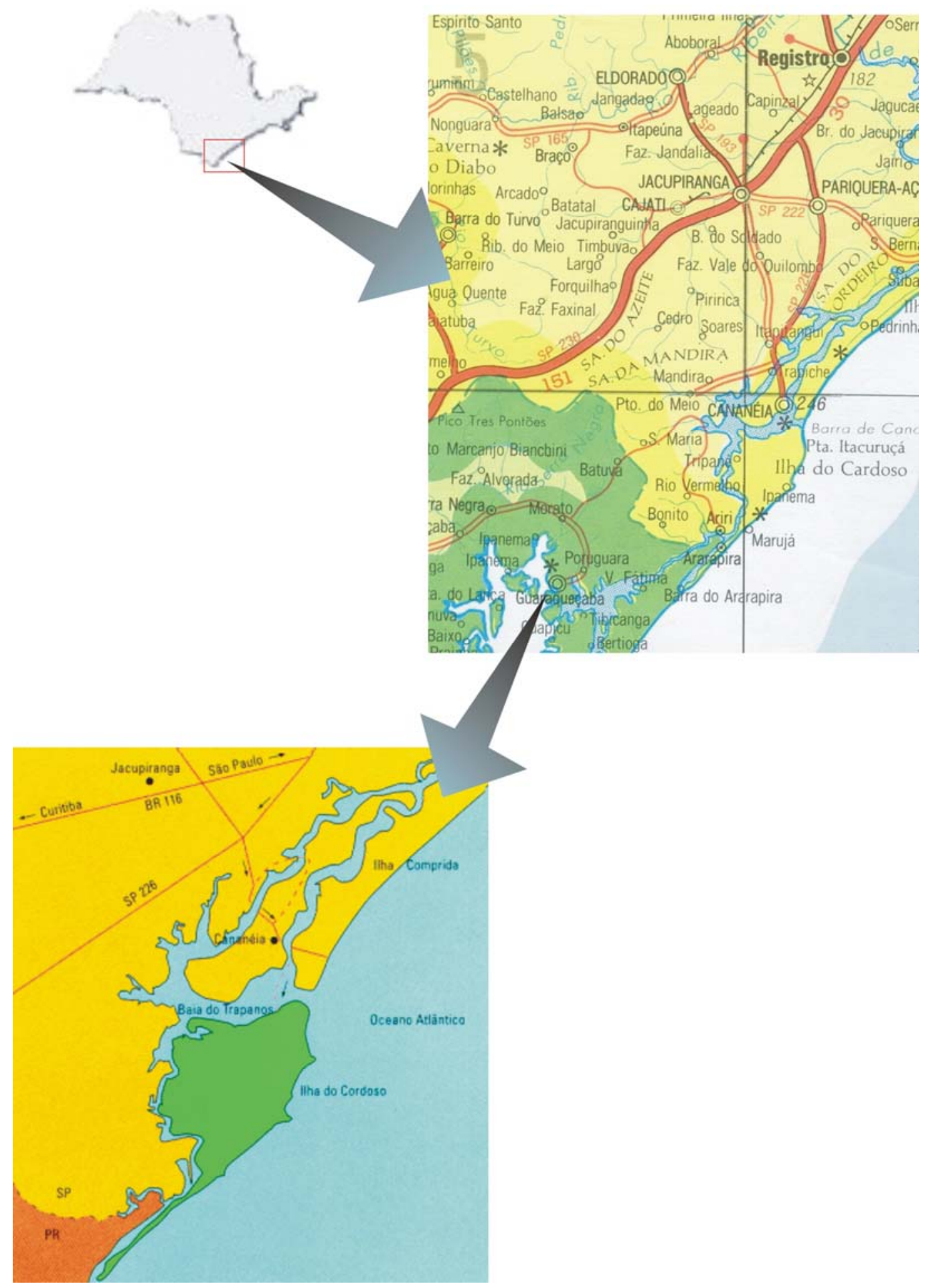

Figura 6 - Região de Cananéia onde se insere a llha do Cardoso Fonte: Composição de figuras de fontes diversas. 


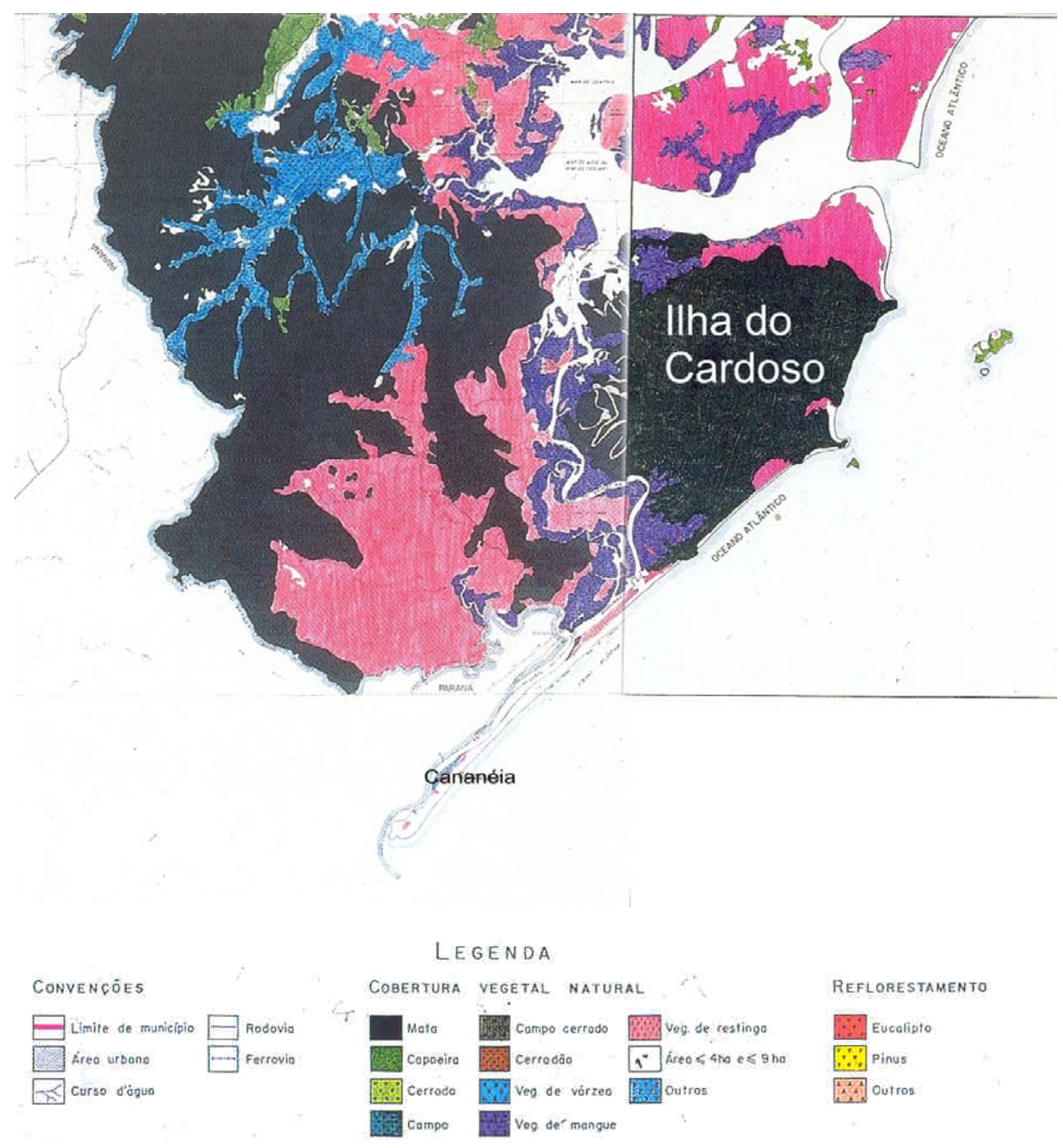

Figura 7 - Cobertura vegetal da região onde se insere a llha do Cardoso (Composição das figuras 85 e 86)

Fonte: IF/SMA. Inventário Florestal do Estado de São Paulo, 1993 (escala 1:250.000). 
Especificamente na área da llha há uma grande variedade de ambientes associados à costa brasileira: Mata Atlântica, Restinga, Duna, Manguezal, Estuário, Praia e Costão rochoso.

Em relação ao Manguezal destaca-se a variação em largura dependente da topografia local, formando faixas extensas em alguns trechos e, em outros, mais restrita à faixa contígua aos rios. As árvores atingem, em média $12 \mathrm{~m}$ de altura e na composição específica figuram as três espécies típicas de Manguezal: R. mangle, A. schaueriana e L. racemosa, que aparecem em bosques mistos ou com predominância de uma ou outra espécie em função das variações ambientais.

\section{- Seleção das áreas de amostragem}

Foram selecionadas três áreas de amostragem na Baixada Santista, submetidas a diversos agentes tensores, em especial contaminação por metais pesados e uma quarta área, localizada na Ilha do Cardoso (Cananéia), sem contaminação - Área Testemunha.

\section{Critérios orientadores da seleção das áreas na Baixada Santista}

- Locais sujeitos a características ambientais similares como condições climáticas, regime de marés e agentes tensores, especialmente poluentes químicos e orgânicos.

- Locais inseridos em região anteriormente estudada pela CETESB (CETESB, 2001a), para os quais se dispõe de dados prévios referentes à avaliação de contaminação em amostras de solo, água e animais (porém não de vegetação).

- Locais com bosque apresentando gradiente estrutural (porte e densidade) para efeito comparativo do grau de contaminação em função da cobertura vegetal. Assim a estrutura do bosque nas áreas selecionadas variou de aberto e baixo, em situação intermediária, e bosque denso e alto. 
Critérios orientadores da seleção da Área Testemunha

- Local com ausência de contaminação, especialmente por metais pesados. A Ilha do Cardoso é área protegida inserida no Parque Estadual da llha do Cardoso, distante de centros urbanizados ou industrializados e relativamente isolada (por ser uma ilha), não havendo atividades antrópicas potencialmente causadoras de contaminação química.

Para ambas as áreas, um critério adicional que orientou a escolha das áreas foi a presença de propágulos, o que viabilizaria a coleta destes para o plantio e a seleção das árvores matrizes sob as quais se implantaria as parcelas para avaliação da regeneração. Assim sendo, vários locais na região (Ex: bosques ao longo de trechos do Canal de Bertioga) foram descartados pois não estavam produzindo propágulos à época do início do trabalho.

\section{Áreas selecionadas}

Foram então selecionadas, empregando os critérios estabelecidos, as áreas apresentadas na Tabela 4, que destaca também os principais tensores que exercem pressão sobre estas áreas. 
Tabela 4. Áreas selecionadas para o estudo e agentes tensores associados

\begin{tabular}{|c|c|c|}
\hline Área & Local & Principais Agentes Tensores \\
\hline \multirow{3}{*}{$\begin{array}{c}\text { AREA } \\
1\end{array}$} & Canal da Cosipa & $\begin{array}{l}\text { Esgotos domésticos, resíduos sólidos } \\
\text { domiciliares e chorume }\end{array}$ \\
\hline & Município: Cubatão & Efluentes químicos industriais \\
\hline & $23^{\circ} 52^{\prime} 26^{\prime \prime S}$ e $46^{\circ} 25^{\prime} 37^{\prime \prime} \mathrm{W}$ & Navegação (efeito de marolas) \\
\hline \multirow{3}{*}{$\begin{array}{l}\text { AREA } \\
2\end{array}$} & Rio Cascalho & $\begin{array}{l}\text { Esgotos domésticos, resíduos sólidos } \\
\text { domiciliares e chorume }\end{array}$ \\
\hline & Estuario de Santos & Efluentes químicos industriais \\
\hline & $23^{\circ} 52^{\prime} 26^{\prime \prime} \mathrm{S}$ e $46^{\circ} 25^{\prime} 37^{\prime \prime} \mathrm{W}$ & \\
\hline \multirow{4}{*}{$\begin{array}{c}\text { AREA } \\
3\end{array}$} & Rio Mariana & \multirow{2}{*}{$\begin{array}{l}\text { Esgotos domésticos in natura, resíduos } \\
\text { sólidos domiciliares e chorume }\end{array}$} \\
\hline & Estuário de São Vicente & \\
\hline & Município: São Vicente & \multirow{2}{*}{$\begin{array}{l}\text { Organoclorados e metais } \\
\text { (arraste de áreas adjacentes) } \\
\text { Ataque de praga (lagarta) }\end{array}$} \\
\hline & $23^{\circ} 57^{\prime} 35^{\prime \prime}$ S e $46^{\circ} 23^{\prime} 15^{\prime \prime} \mathrm{W}$ & \\
\hline \multirow{4}{*}{$\begin{array}{l}\text { AREA } \\
\quad 4\end{array}$} & Ilha do Cardoso-Rio Perequê & \multirow{4}{*}{ Área testemunha } \\
\hline & $\begin{array}{l}\text { Complexo estuarino-lagunar de } \\
\text { lquape, Cananéia e Paranaquá }\end{array}$ & \\
\hline & Município: Cananéia & \\
\hline & $25^{\circ} 03^{\prime} \mathrm{S}$ e $47^{\circ} 55^{\prime} \mathrm{W}$ & \\
\hline
\end{tabular}


Área 1

O ponto de amostragem fica às margens do Canal da Cosipa, portanto inserido no Estuário de Santos que recebe as drenagens dos municípios de Cubatão, Santos e Guarujá e em região de grande intensidade de atividades industriais (especialmente siderúrgicas e petroquímicas), recebendo efluentes químicos industriais especialmente da COSIPA e também da Ultrafértil e Dow Química; influência dos Terminais portuários; esgotos domésticos e resíduos sólidos domiciliares.

Um impacto de ocorrência periódica no local advém do processo de dragagem do canal para possibilitar o trânsito de grandes navios, que contribui para a ressuspensão de substâncias contaminantes depositadas no fundo. $O$ próprio trânsito de embarcações também provoca impacto devido ao deslocamento repentino da água, formando marolas, responsáveis pela queda de árvores na faixa mais externa do bosque e o arraste de propágulos e mudas.

A situação do Bosque de Manguezal apresenta-se bastante alterada, sendo a faixa de vegetação estreitada devido a uma grande clareira existente ao fundo da área, além de densidade e porte mais baixos.

As Figuras 8 e 9 ilustram a situação da área.

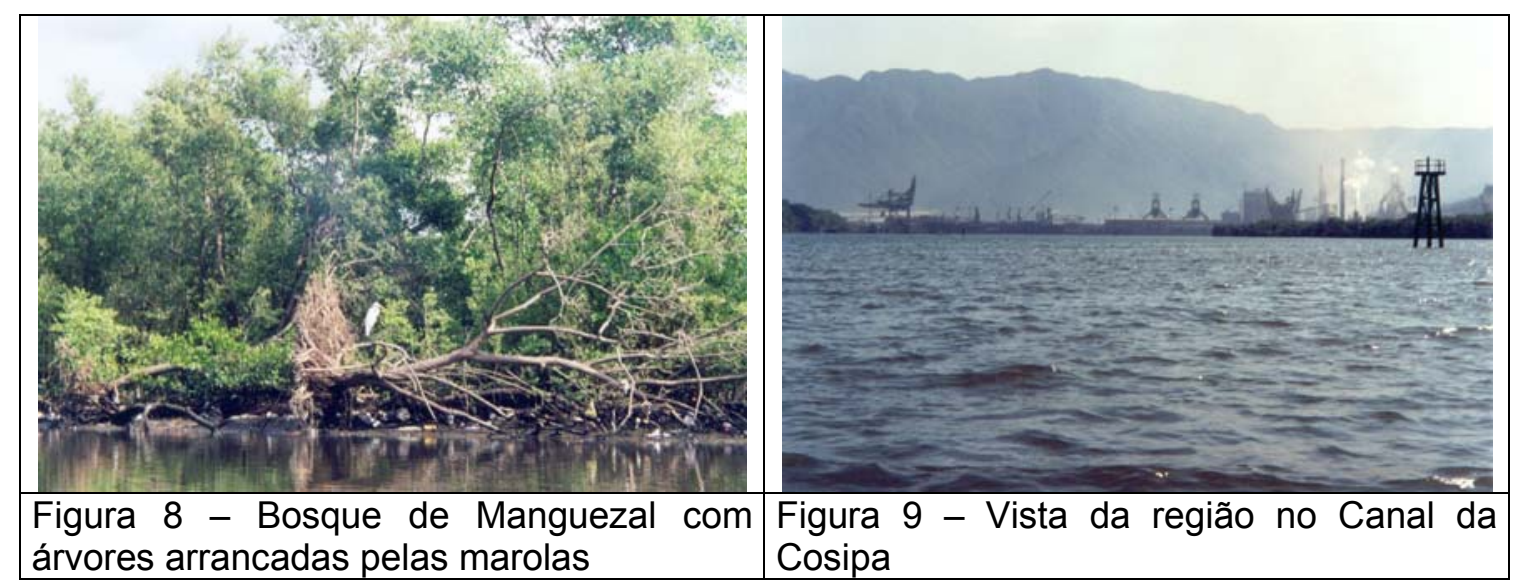




\section{Área 2}

O ponto de amostragem fica às margens do Rio Cascalho, localizado não muito distante da Área 1, de forma que também recebe influência dos efluentes químicos e resíduos orgânicos lançados nos rios da região (fontes difusas). Pode estar também recebendo influência do chorume do Lixão da Alemoa.

Nesta área não existe o problema de navegação com marolas, porém foi alvo de infestação por lagarta com desfolhamento e ressecamento da copa, apresentando várias árvores com copa parcialmente atacada (ataque não muito intenso). As condições do bosque quanto a estrutura pode ser considerada intermediária entre as outras duas áreas da Baixada Santista.

As Figuras 10 e 11 ilustram a situação da área.

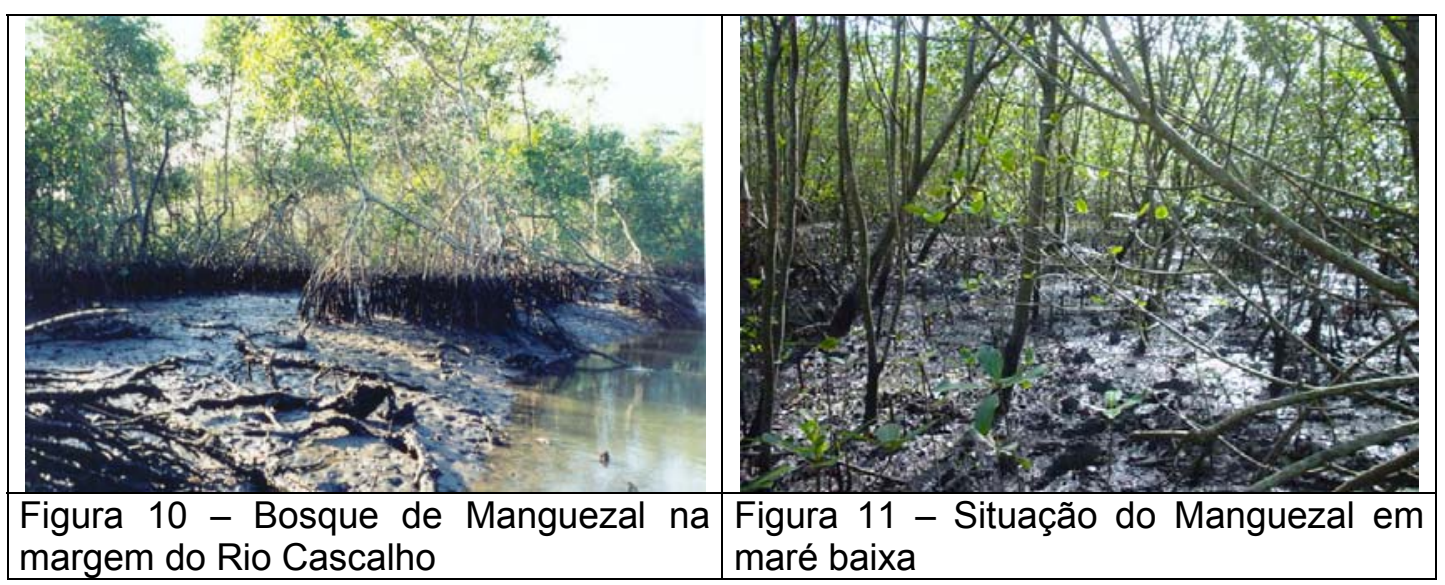




\section{Área 3}

O ponto de amostragem fica às margens do Rio Mariana, em área pertencente à empresa Rhodia e está inserido no Estuário de São Vicente que recebe as drenagens dos municípios de São Vicente e Praia Grande. Neste local há possibilidade de contaminação por organoclorados e metais pesados depositados nas áreas adjacentes de Restinga e arrastados para as áreas mais baixas de Manguezal, além de ser receptor de esgotos domésticos in natura e chorume do Lixão de Sambaiatuba.

Apresenta o bosque de Manguezal estruturalmente mais desenvolvido, com maior porte e densidade e também uma visível maior diversidade de espécies, especialmente de epífitas. Algumas árvores no local apresentavam sintomas de ataque por lagartas, porém sem danos muito expressivos.

As Figuras 12 e 13 ilustram a situação da área.

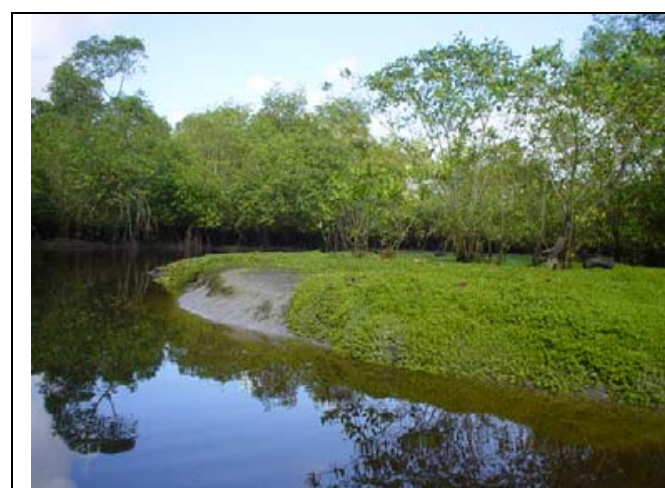

Figura 12 - Bosque de Manguezal no Rio Mariana

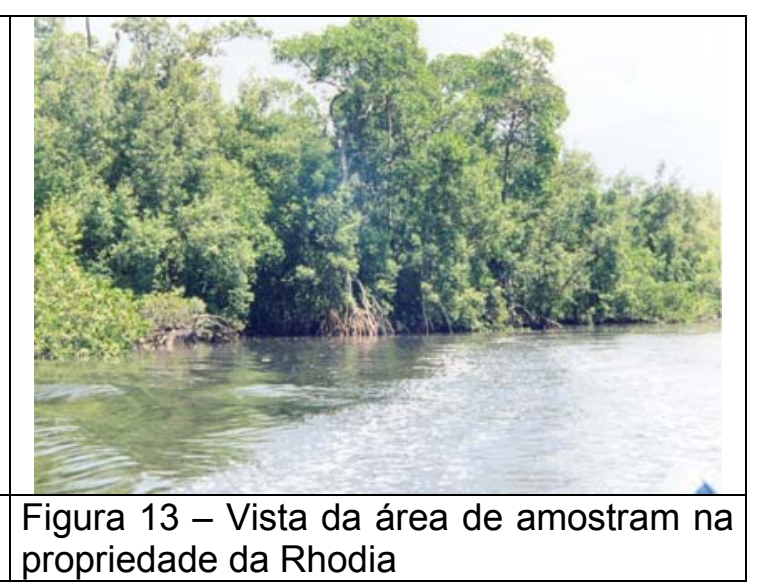




\section{Área 4}

O ponto de amostragem fica às margens do Rio Perequê, área inserida no Parque Estadual da llha do Cardoso (com área aproximada de $151 \mathrm{~km}^{2}$ ), administrado pelo Instituto Florestal (SMA) e que pertence ao ComplexoEstuarino-Lagunar de Iguape-Cananéia-Paranaguá, tendo como limite, a leste, Oceano Atlântico; a norte e nordeste, a Baía de Trapandé e a oeste e sul, o Canal de Ararapira.

O isolamento desta llha e situação regional, onde não há intensa ocupação e nem atividades industriais expressivas, além das medidas de controle típicas de uma Unidade de Conservação da natureza são condições que minimizam os agentes tensores associados à contaminação, especialmente aqueles relacionados a metais pesados.

As Figuras 14 e 15 ilustram a situação da área.

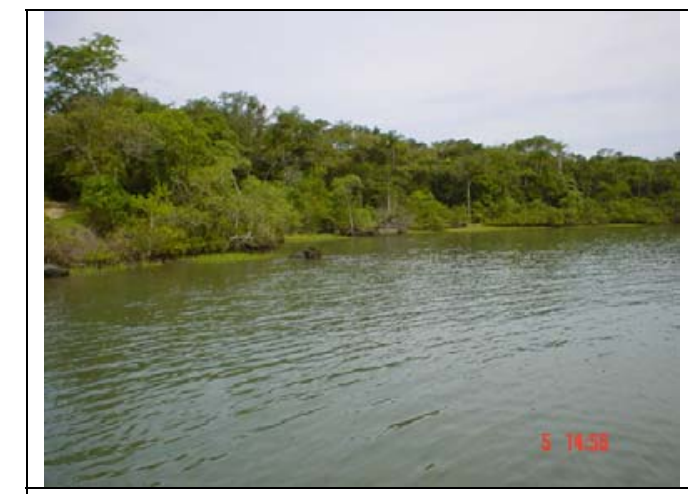

Figura 14 - Aspecto da vegetação da Ilha do Cardoso

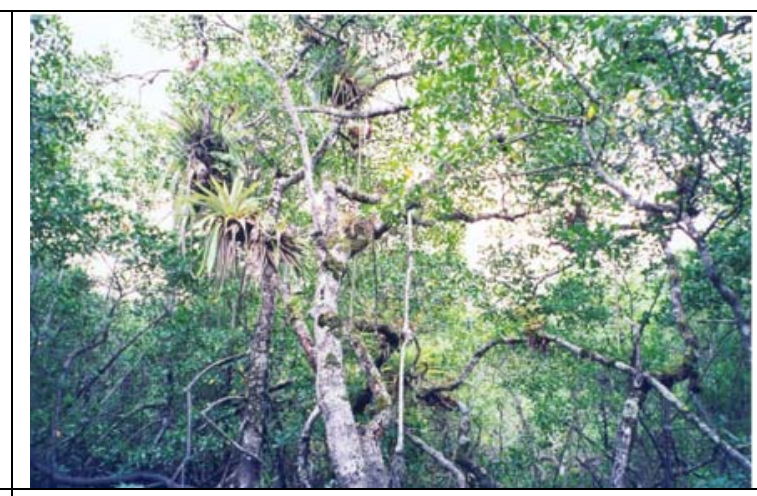

Figura 15 - Vista do bosque de Manguezal na llha do Cardoso

Para as três áreas da Baixada Santista as águas são consideradas salobras (com salinidade $\geq 0,5 \%$ e $30 \%$ ) e o enquadramento dos cursos d'água é na Classe 7, ou seja, águas destinadas à recreação de contato primário, à proteção das comunidades aquáticas e à aqüicultura de espécies destinadas à alimentação humana, de acordo com a Resolução CONAMA 20/86. 
- Interpretação de aerofotografias

Para cada aerofoto foi feita a interpretação visual (macro-avaliação) utilizando todo o campo das fotos. Esta informação orientou as avaliações de campo na fase de seleção das áreas de amostragem.

Em cada local selecionado foram tomadas as coordenadas geográficas (empregando GPS-12) que possibilitou a identificação exata dos pontos de amostragem. Foi então realizada uma interpretação mais detalhada (digital), considerando um raio de $1 \mathrm{Km}{ }^{7}$ ao redor destes pontos.

Esta análise possibilitou um melhor entendimento da situação das áreas, identificação das tensões ambientais atuantes e sobre as características do bosque. A Figura 16 apresenta a metodologia de interpretação empregada.

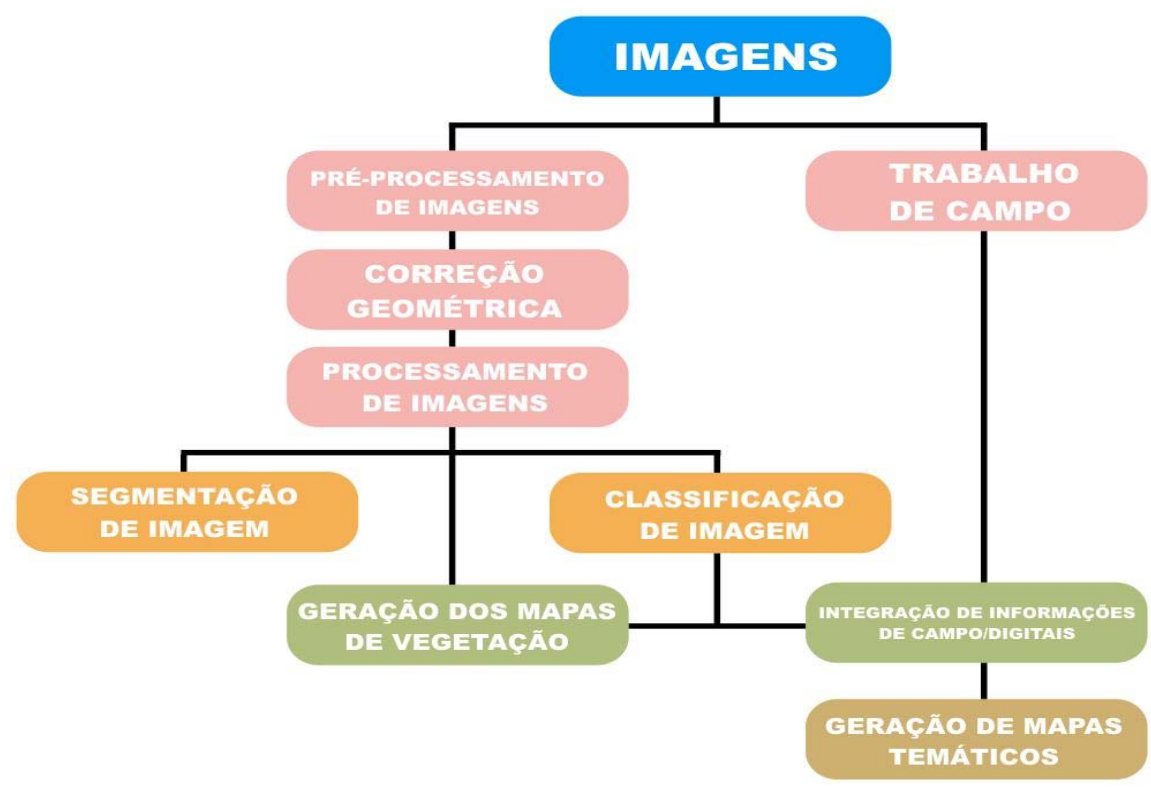

Figura 16 - Fluxograma da metodologia de fotointerpretação digital

\footnotetext{
${ }^{7} \mathrm{O}$ referido raio foi definido em função do campo fotográfico, pois os locais de amostragem não ficaram centralizados em todas as aerofotos, sendo que a distância da margem (descontando uma faixa de possível distorção), condicionou o campo da foto possível de interpretação. Para padronizar a avaliação das quatro áreas o raio de amostragem foi então definido em $1 \mathrm{~km}$.
} 
O trabalho de campo foi dividido em duas etapas: aquisição de pontos de controle (demarcados com GPS) e reconhecimento da paisagem.

A digitalização das quatro fotografias aéreas foi feita via scanneamento das imagens (com resolução de 600 dpi) e o pré-processamento digital destas foi realizado no software SPRING, versão 4.0 .

A correção geométrica foi realizada com o registro imagem-mapa, contando com os pontos de controle. Visando a distribuição de pontos por toda a imagem, houve a necessidade de aquisição de pontos, em cartas temáticas oficiais, dos locais de difícil acesso.

Foram utilizados oito pontos de controle por imagem, para obtenção de um erro menor que meio pixel. O polinômio de transformação empregado foi o de primeiro grau e a reamostragem dos pixels foi realizada pelo método do vizinho mais próximo, a fim de manter as características radiométricas da imagem original, com o mínimo de alterações nos níveis de cinza.

Devido a problemas de luminosidade nas fotografias, com presença concomitante de luz e sombra de nuvens nas áreas correspondentes ao Rio Mariana, Rio Cascalho e Canal da Cosipa, na primeira etapa do processo de classificação foi efetuada uma segmentação das imagens para a separação das possíveis classes existentes em cada fotografia. Na segunda etapa, com base nos critérios cor e forma combinadas, foram definidas as áreas homogêneas. Tendo as áreas segmentadas, utilizando amostras de classe e fusão de objetos, foram definidas as classes de cada área.

O método utilizado para classificação não supervisionada foi o ISODATA, com o qual a classificação é realizada por regiões (não por pixels), utilizando como amostras as classes previamente segmentadas e definidas, projetando agrupamentos específicos por meio de funções discriminantes que dividem o espaço em regiões de decisão em função da densidade de probabilidade gaussiana, separando categorias em função das classes informadas. 
Assim, foram gerados os mapas temáticos com a interpretação dos padrões de tipologia vegetal e uso do solo nas áreas amostradas, sendo definidos nove padrões, para os quais foi calculada a área de cobertura e percentual em relação ao total de $1 \mathrm{Km}^{2}$ tomada para as análises. Dentre os nove padrões citados, incluídos na legenda das aerofotointerpretações, quatro se referem a tipologias vegetais (Manguezal, Restinga, Floresta e Praia), três se referem a formações naturais ou processos resultantes indiretamente de atividades antrópicas (banco de areia, solo exposto e cursos d'água) e dois representam usos do solo associados à antropização intensa (área de uso intensivo e estrada).

\section{- Metais estudados}

A região da Baixada Santista é submetida a diversos tipos de poluição, porém optou-se pelo estudo dos metais pesados em função de sua importância como poluidores, pela característica de acumularem-se nos seres vivos, sendo transferidos através da cadeia alimentar, e por terem sido anteriormente estudados pela CETESB, na mesma região, para água, sedimentos e organismos, mas não para vegetais, o que representa uma lacuna.

Assim sendo, os elementos estudados foram os seguintes metais pesados: Cádmio $(\mathrm{Cd})$, Chumbo $(\mathrm{Pb})$, Cobre $(\mathrm{Cu})$, Cromo $(\mathrm{Cr})$, Estanho $(\mathrm{Sn})$, Mercúrio (Hg), Níquel (Ni) e Zinco (Zn). 


\section{- Coleta e preparação dos propágulos}

Coleta de propágulos

A coleta foi realizada nas quatro áreas de amostragem, sendo coletados cerca de 300 propágulos de Rhizophora mangle na llha do Cardoso e 150 propágulos em cada área da Baixada Santista. Tal quantidade foi definida em função do planejamento do plantio de 50 propágulos da llha do Cardoso e 50 propágulos da própria área em cada área e mais um lote para secagem, outro para as análises químicas e um outro de reserva para replantio.

Foram coletados propágulos caídos (no chão e boiando na água). Não foram coletados aqueles ainda presos à árvore-mãe (há autores que indicam a coleta dos caídos pois estariam maduros, e, portanto, mais aptos ao plantio). A forma de coleta foi aleatória, pelo caminhamento na área, coletando-se os propágulos encontrados em boas condições (inteiros, sem danos mecânicos), de forma que houve grande variação de comprimento e diâmetro, inclusive alguns já com raízes. O acondicionamento para transporte foi feito em baldes. Devido à necessidade de reposição de mudas em função das perdas no plantio, as coletas foram realizadas duas vezes, com a mesma metodologia.

As Figuras 17 e 18 ilustram o processo de coleta e o propágulo vivíparo.

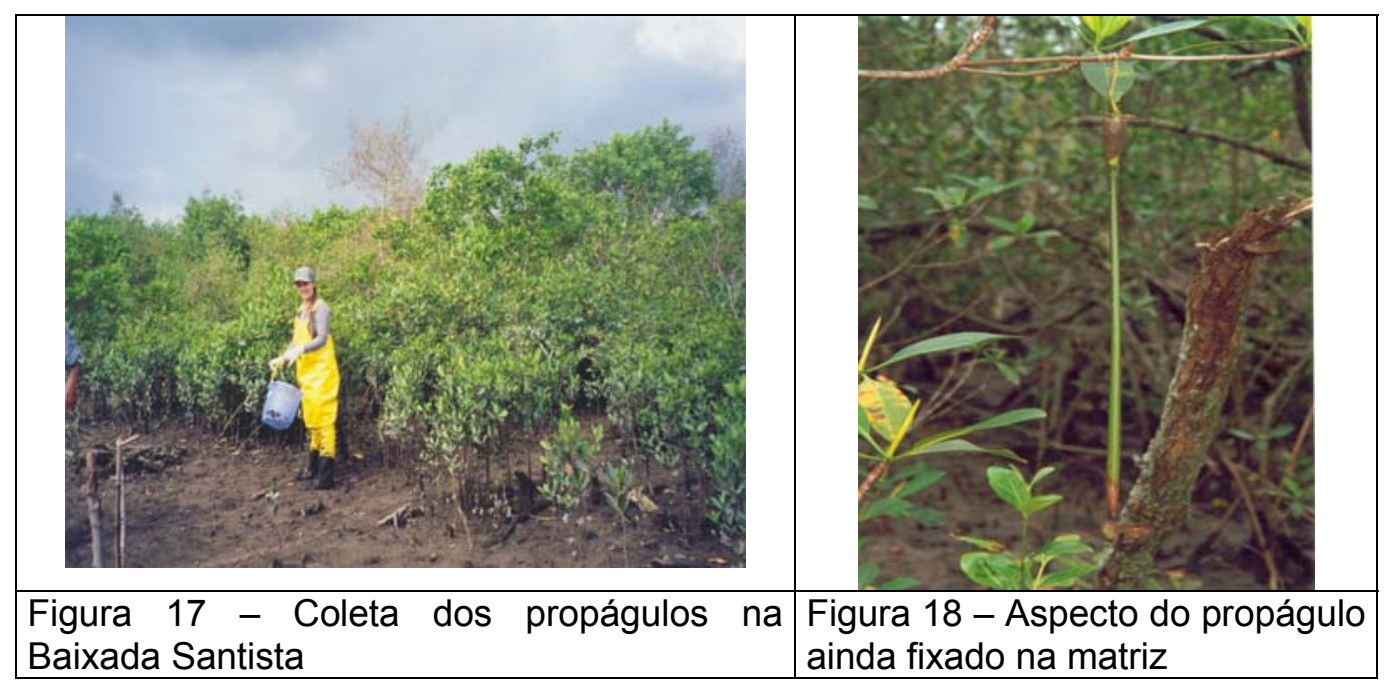


Mensuração dos propágulos

Os propágulos foram levemente lavados com esponja de espuma macia, em água corrente, para retirada dos sedimentos de solo e enxugados para retirada do excesso de água. Foram então mensurados: comprimento (fita métrica em $\mathrm{cm}$ ), diâmetros da base, centro e ápice (paquímetro digital em $\mathrm{mm}$ ) e Massa úmida - MU (balança de campo e digital em g).

As Figuras 19 a 22 ilustram o processo de mensuração dos propágulos.

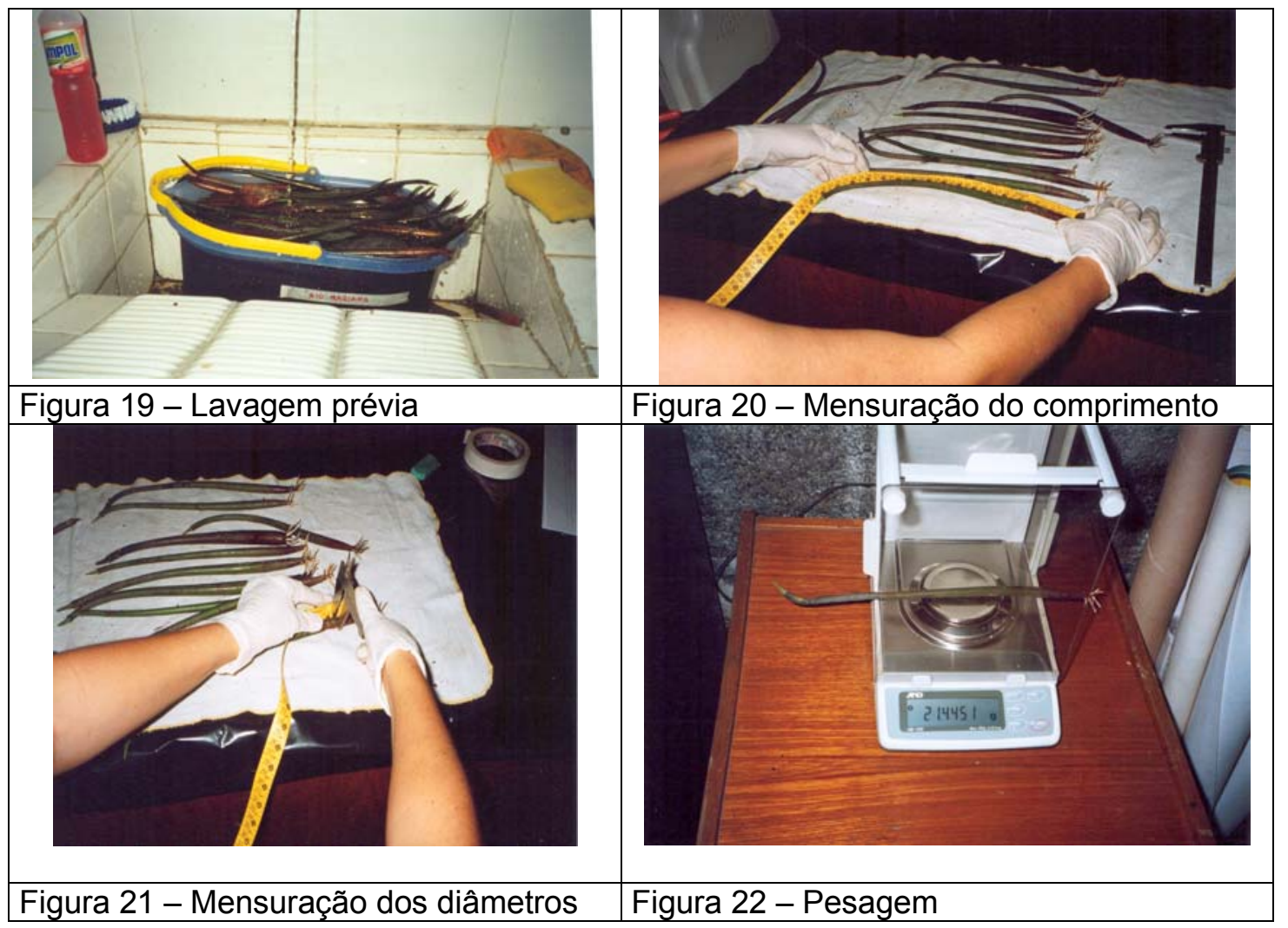


Após as mensurações foram separados lotes mistos de propágulos de todos os tamanhos, destinados à:

- Plantio nas áreas da Baixada Santista - um lote de 100 propágulos/área (50 propágulos coletados na área contaminada e 50 propágulos coletados na área testemunha);

- Plantio na Ilha do Cardoso - um lote de 50 propágulos oriundos apenas desta própria área, evitando-se a introdução de propágulos passíveis de contaminação neste local;

- Secagem - um lote de 20 propágulos/área, encaminhados para secagem em estufa para posterior estudo de conversão Massa úmida - Massa seca;

- Análises químicas - um lote de 20 propágulos/área, encaminhados para realização das análises de concentração dos metais estudados e

- Reserva de propágulos - mantidos para possível replantio.

Acondicionamento dos propágulos

Cada lote foi embalado e acondicionado de acordo com a finalidade. Os propágulos destinados às análises químicas e secagem foram embalados em jornal e saco plástico aberto (para evitar acúmulo de água evaporada e emboloramento ou apodrecimento). Já os propágulos destinados ao plantio foram embalados (junto com a respectiva estaca e plaqueta de identificação) em jornal constantemente umedecido e acondicionados em baldes na posição vertical. O período entre coleta e plantio não excedeu 30 dias.

Os propágulos reservados para replantio foram também enrolados em jornal umedecido e acondicionados em baldes. No período entre plantio e replantio a grande maioria dos propágulos reservados desenvolveram, dentro dos baldes, radículas e algumas folhas.

As Figuras 23 e 24 ilustram o acondicionamento dos propágulos. 


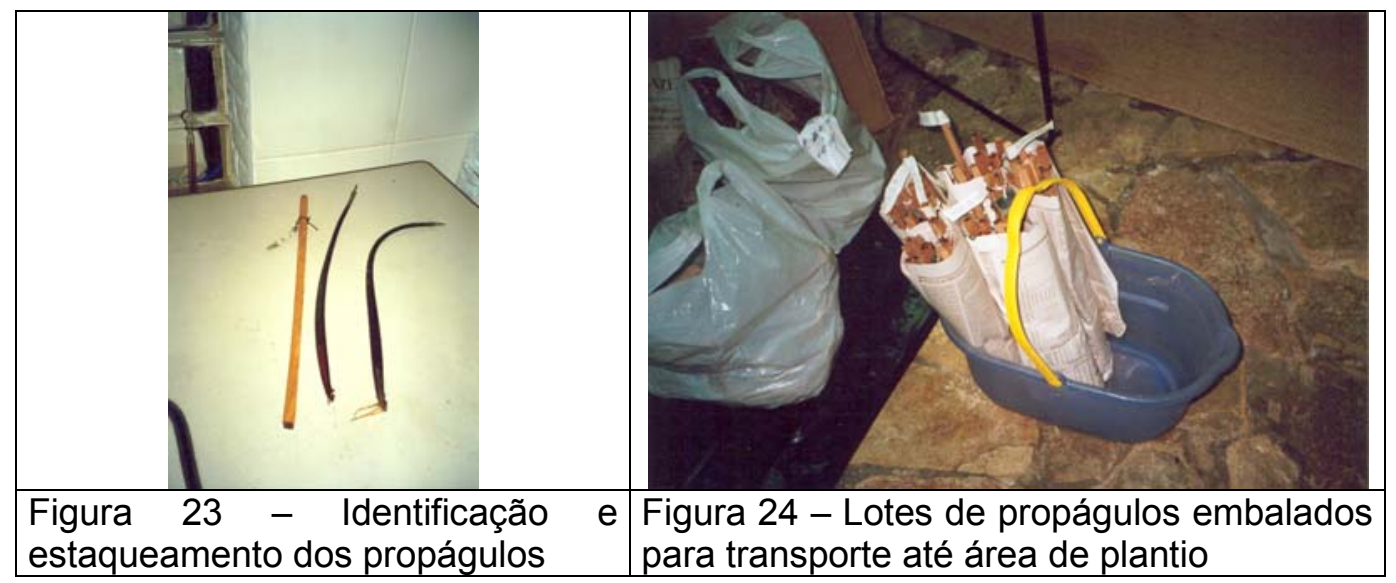

Secagem dos propágulos

A secagem dos propágulos foi realizada em estufa com temperatura de $100^{\circ} \mathrm{C}$ até constante, quando foram pesados para obtenção da Massa seca. $\mathrm{O}$ objetivo de tal procedimento foi a geração de dados para obtenção da relação de conversão Massa seca / Massa úmida (MS:MU).

- Demarcação das unidades de amostragem e mensurações

As unidades de amostragem (parcelas) foram implantadas, nas áreas selecionadas, na faixa mais próxima do curso d'água de forma a assegurar que a água das marés (veículo transportador de poluentes) estivesse em constante contato com as plantas amostradas e que as amostras fossem instaladas na zonação onde predomina o Mangue vermelho, espécie sob enfoque.

Em cada área da Baixada Santista foram implantadas duas parcelas de árvore matriz, uma parcela de inventário do bosque e uma parcela de plantio. Para a Ilha do Cardoso, apenas uma área de plantio foi implantada. 
Parcela de árvore matriz

Foram selecionadas aleatoriamente duas árvores matrizes/área, sendo adotado o critério de que esta estivesse frutificando e que sua posição fosse tal que haveria constante alcance das águas (proximidade da margem do rio). No entorno destas árvores foi demarcada uma parcela circular de $2 \mathrm{~m}$ de raio, dividida em quatro setores limitados pelas linhas de sentido dos pontos cardeais. A parcela e seus setores foram demarcados empregando estacas coloridas e barbante. O esquema apresentado na Figura 25 ilustra a parcela implantada e as Figuras 26 e 27 a situação em campo.

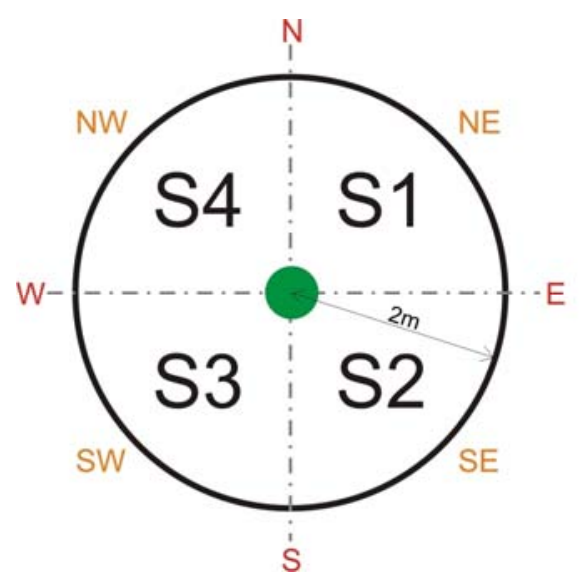

Árvore Matriz

S1 à S4 - Setores da Parcela

Figura 25 - Parcela de árvore matriz implantada nas áreas da Baixada Santista

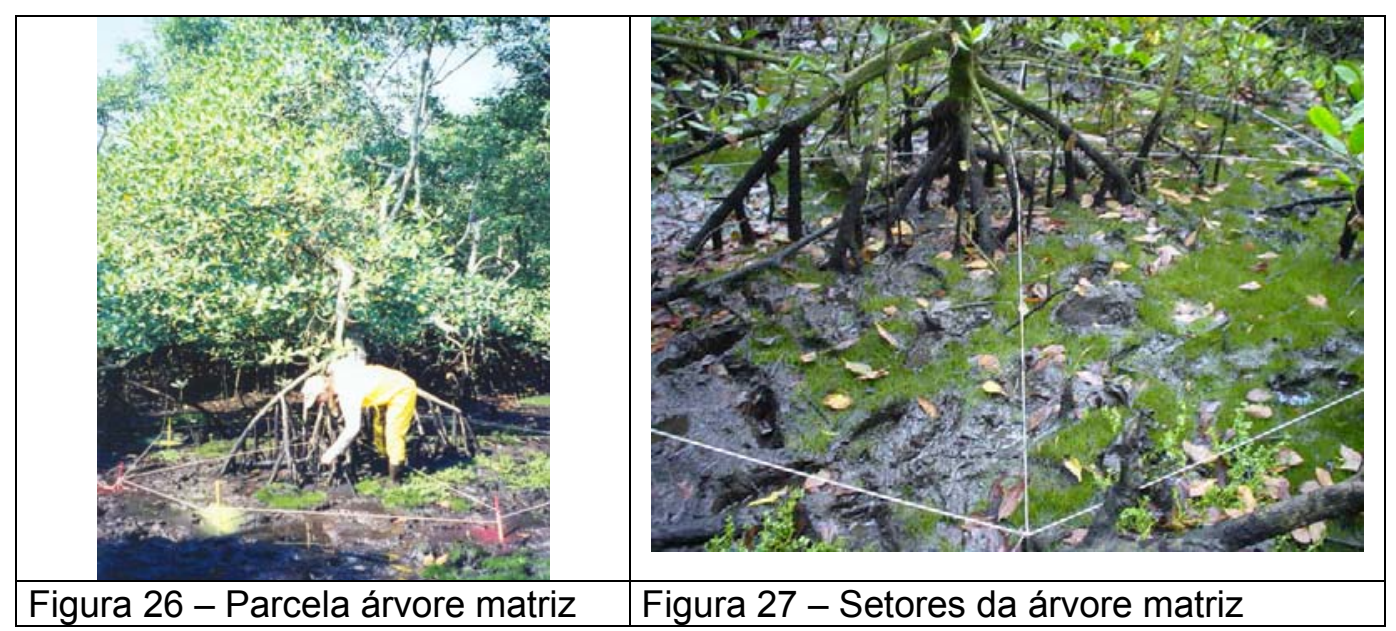


O tronco principal e/ou todos os brotos da árvore matriz foram numerados e marcados com plaqueta de alumínio, fixada com prego galvanizado. Os dados da matriz e dos indivíduos jovens sob a matriz foram coletados na parcela, de forma contínua, em intervalos semestrais.

Para avaliação do desenvolvimento da árvore matriz foram mensurados os seguintes parâmetros: DAP de todos os brotos (com suta dendrométrica, em $\mathrm{cm}$ ); Altura total da árvore, do fuste e da copa (avaliada visualmente com comparação com vara de altura conhecida, em m); extensão horizontal predominante das raízes (com fita métrica, em $\mathrm{m}$ ); altura predominante das raízes (com fita métrica, em $\mathrm{m}$ ); projeção da copa nos sentidos N, S, E, W (o mensurador se posicionou abaixo da projeção da ponta do ramo mais comprido e a extensão entre o tronco e a posição do mensurador foi anotada) e foi observado a presença de flor ou fruto.

As Figuras 28 e 29 ilustram a mensuração e plaqueamento.

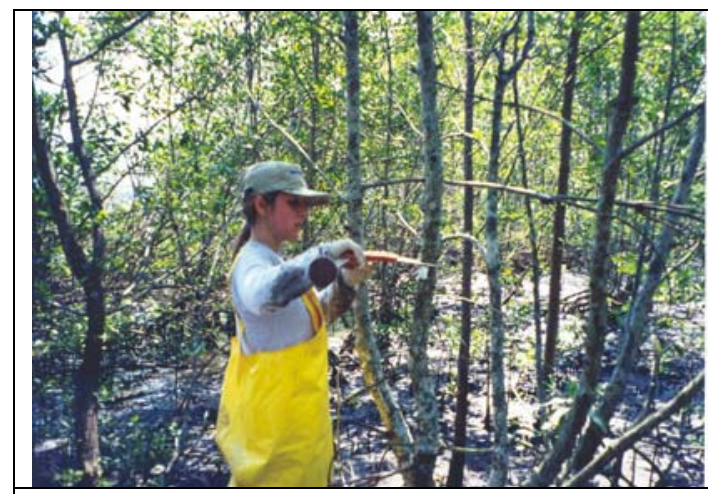

Figura 28 - Mensuração do DAP

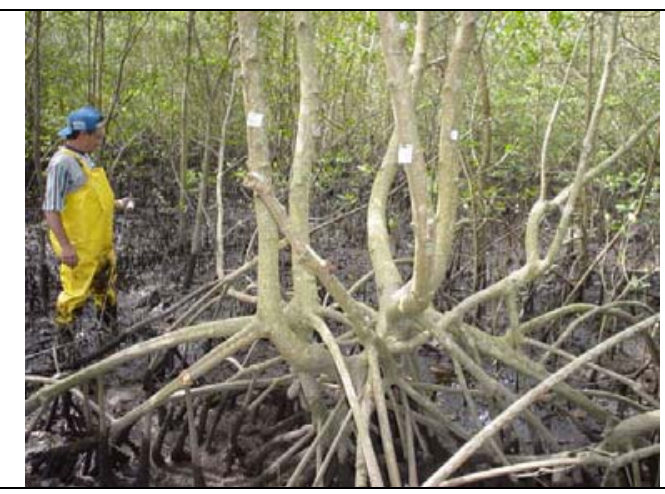

Figura 29 - Marcação das árvores

Os indivíduos jovens (propágulos e mudas) foram contados nos setores da parcela sob a matriz. Foram contados os propágulos enraizados e sem raízes (superficiais) de $R$. mangle e de $A$. shaueriana, as mudas de $R$. mangle (altura até $20 \mathrm{~cm}$, de 20,1 a $40 \mathrm{~cm}, 40,1$ a $60 \mathrm{~cm}, 60,1$ a $80 \mathrm{~cm}$ e maior que $80 \mathrm{~cm}$ ) e mudas de outras espécies (até $80 \mathrm{~cm}$ e maior que $80 \mathrm{~cm}$ ). Quando necessário o setor foi subdividido para maior controle da contagem. 
Parcela de inventário

Foi implantada uma parcela de inventário do bosque/área na Baixada Santista, sendo estas de forma retangular e área de $150 \mathrm{~m}^{2}(5,0 \mathrm{~m} \times 30,0 \mathrm{~m})$, subdividida em doze setores de $12,5 \mathrm{~m}^{2}(2,5 \mathrm{~m} \times 5,0 \mathrm{~m})$. Na implantação da parcela foi utilizado trena de $50 \mathrm{~m}$ e bússola (para garantir extremidades com ângulos de $90^{\circ}$ ) e, como os dados foram coletados de forma contínua, em intervalos semestrais, a parcela e seus setores foram marcados com estacas de madeira e barbante.

O esquema apresentado na Figura 30 ilustra a parcela implantada, assim como as fotos das Figuras 31 e 32.

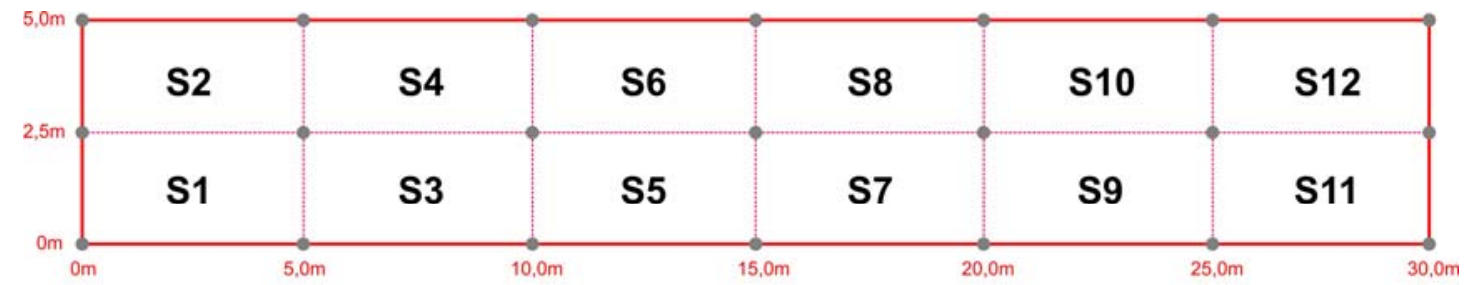

S1 à S12 - Setores da Parcela

- Estacas

Figura 30 - Parcela de inventário implantada nas áreas da Baixada Santista

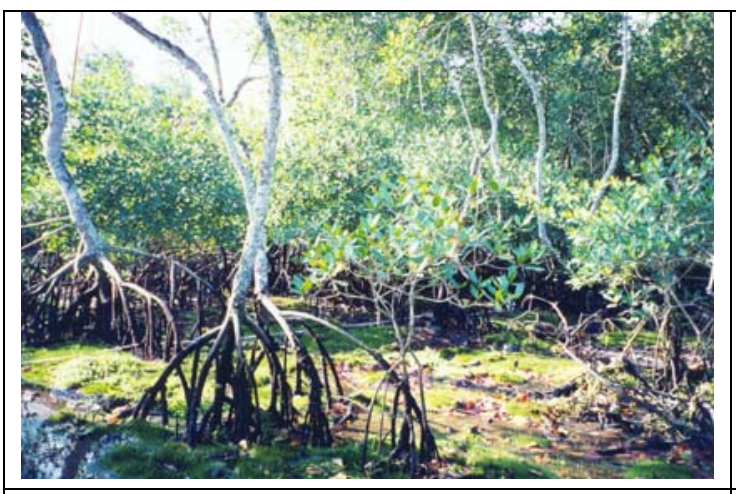

Figura 31 - Parcela de inventário na área de amostragem do Rio Mariana

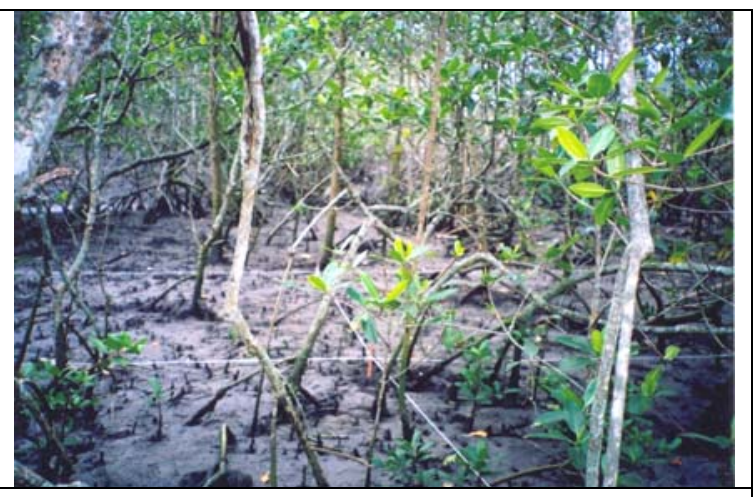

Figura 32 - Parcela de inventário na área de amostragem do Canal da Cosipa 
Os indivíduos arbóreos com DAP mínimo de $5 \mathrm{~cm}$ (considerados adultos) de qualquer espécie foram numerados e marcados com plaqueta de alumínio, fixada com prego galvanizado. Estes indivíduos foram avaliados de forma contínua em períodos semestrais, sendo mensurados os seguintes parâmetros: DAP de todos os brotos (com suta dendrométrica, em $\mathrm{cm}$ ); altura total da árvore, do fuste e da copa (visualmente com comparação com vara de altura conhecida, em $\mathrm{m}$ ); altura predominante das raízes (com fita métrica, em $\mathrm{m}$ ); projeção da copa nos sentidos N, S, E, W (seguindo a mesma metodologia adotada para árvores matriz) e presença de floração e frutificação.

Os indivíduos jovens (com DAP inferior a $5 \mathrm{~cm}$ ) foram avaliados por meio da quantificação, com contagem de propágulos e mudas (divididas em classes de altura), presentes em cada um dos doze setores da parcela. Assim sendo, contou-se os propágulos enraizados e sem raízes (superficiais) de $R$. mangle, a quantidade de mudas de $R$. mangle (com altura até $80 \mathrm{~cm}$ e maior que $80 \mathrm{~cm}$ ), a quantidade de mudas de $L$. racemosa (até $80 \mathrm{~cm}$ e maior que $80 \mathrm{~cm}$ ) e a quantidade de indivíduos de outras espécies terrestres (basicamente de Samambaia do mangue - Acrosticum aureum). Quando necessário o setor foi subdividido para um maior controle da contagem.

Foi também avaliada a estrutura do bosque, uma vez que este parâmetro foi critério de seleção das áreas de amostragem e indica o grau de degradação do Manguezal. Assim, foram elaborados os desenhos do perfil horizontal e vertical do bosque tomando como referência a parcela de inventário. Para garantir a escala, o desenho foi feito em papel milimetrado, contando com as referências de distância da marcação dos setores e referências de altura das árvores mensuradas no inventário. 


\section{Parcela de plantio}

Depois de mensurados, identificados (com as plaquetas afixadas nas estacas) e acondicionados adequadamente, os propágulos foram transportados por via terrestre (carro) e aquática (barco) até as áreas de plantio, sendo mantidos à sombra durante todo o percurso.

Em cada área, a parcela de plantio foi selecionada tendo como critérios principais a existência de uma área de menor densidade de árvores e de mudas e o distanciamento do curso d'água que permitisse o alcance permanente pela água no período de maré cheia (visando contato com água, essencial ao propágulo mas também carreadora dos contaminantes). A implantação das parcelas de plantio foi feita também de forma a possibilitar a avaliação de várias condicionantes ambientais, tal como o afastamento da muda em relação ao curso d'água (posição perpendicular ou paralela ao rio além da variação da distância da parcela em relação ao rio), efeito da luminosidade (parte da parcela sob insolação/parte sob mata ou integralmente sombreada ou integralmente à pleno sol).

As extremidades da parcela e as linhas de plantio foram demarcadas com estacas visíveis.

O plantio foi realizado seguindo as recomendações metodológicas obtidas em trabalhos pré-existentes de recuperação de Manguezais com propágulos, ou seja, estes foram plantados fazendo-se um pequeno orifício no solo com estaca de madeira, onde foram enterrados até dois terços de seu comprimento e a terra do entorno comprimida levemente; quando o propágulo já apresentava raízes e/ou folíolos, tomou-se o cuidado de não danificá-las no processo de plantio. Cada propágulo plantado teve a estaca com a plaqueta de identificação fincada a poucos centímetros para garantir sua posterior localização e diferenciação das mudas da regeneração natural que pudessem estar presentes no local de plantio. 
$\mathrm{Na}$ Ilha do Cardoso foram plantados 50 propágulos, todos coletados no próprio local (2 linhas de 25 plantas, em espaçamento de $50 \mathrm{~cm}$ entre plantas e $100 \mathrm{~cm}$ entre linhas). Nas três áreas da Baixada Santista foram plantados 50 propágulos coletados no local e 50 propágulos trazidos da área testemunha (4 linhas de 25 plantas, mantendo o mesmo espaçamento entre plantas e linhas).

O esquema apresentado na Figura 33 ilustra a parcela de plantio e as fotos das Figuras 34 e 35 o processo de plantio e área plantada.

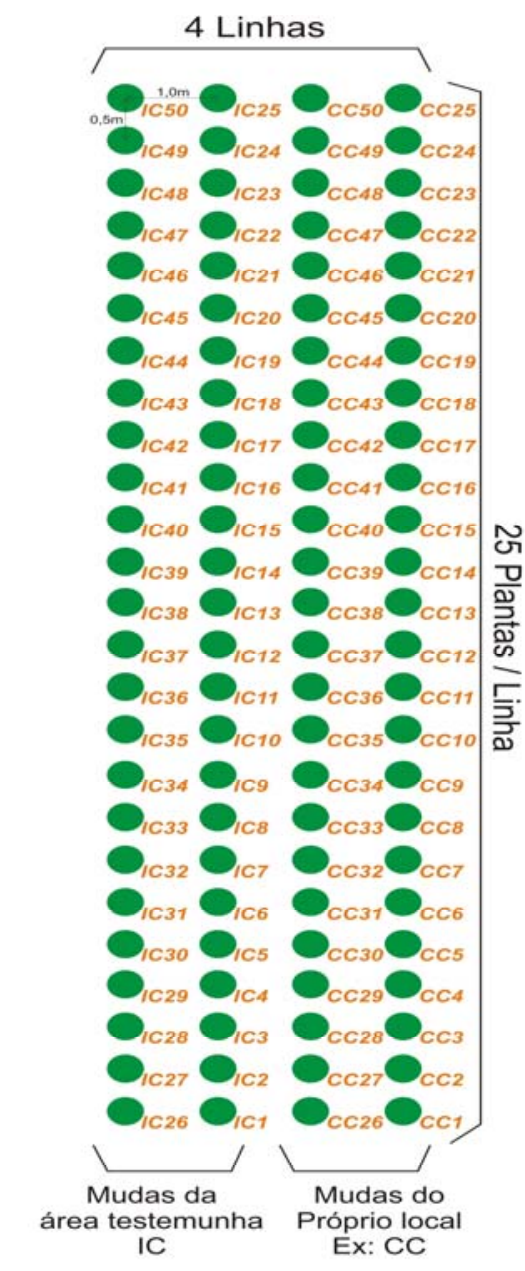

Áreas da Baixada Santista (a)

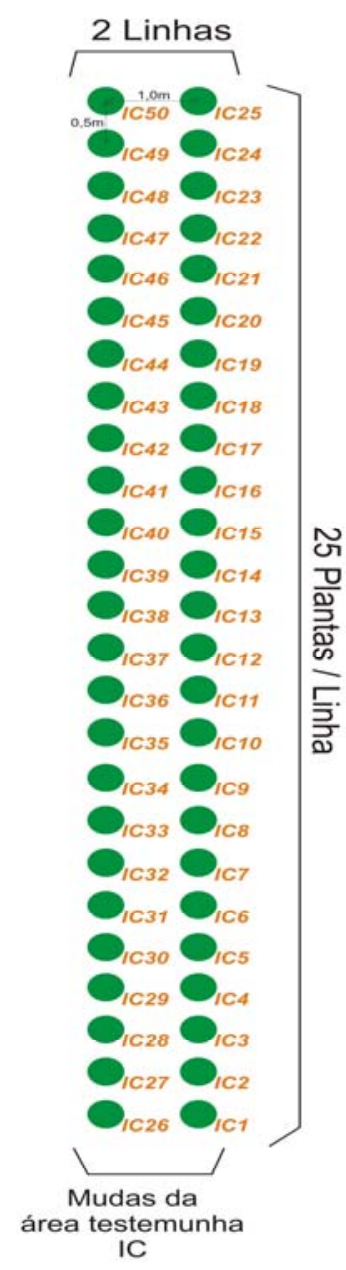

Área Testemunha Ilha do Cardoso - (b)

Figura 33 - Parcela de plantio na Baixada Santista e Ilha do Cardoso 


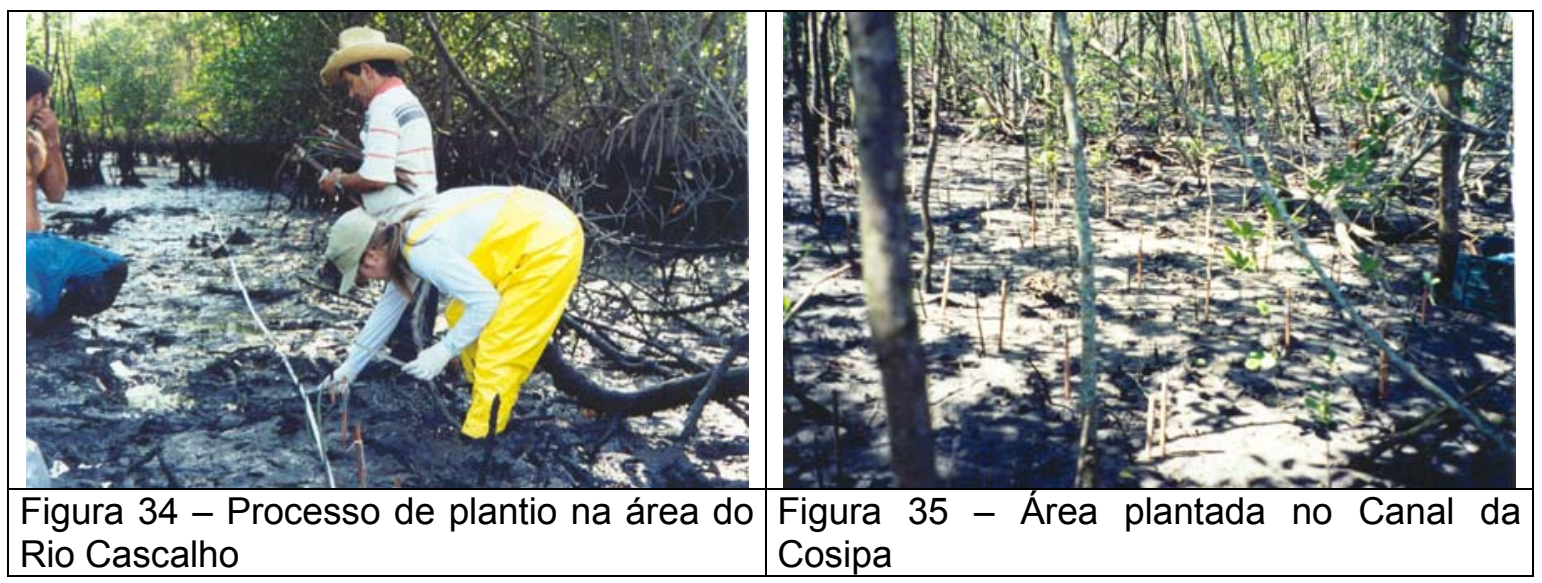

$\mathrm{Na}$ ocasião do plantio foram mensurados e observados os seguintes parâmetros: diâmetro do colo do propágulo (mensurado com paquímetro, na altura do solo, logo após o plantio), comprimento da parte aérea (altura de plantio, medida com régua), contagem do número de ramos e folhas, existência de enraizamento no propágulo e observações adicionais diversas (presença de brotações, danos físicos, etc). Os dados do plantio foram coletados de forma contínua, em intervalos semestrais repetindo-se as medições e observações realizadas no plantio.

\section{- Replantio}

Como houve a perda de propágulos plantados nas três áreas da Baixada Santista, parcelas substitutivas foram implantadas seguindo a mesma metodologia do primeiro plantio. Para o Rio Cascalho e Rio Mariana apenas uma nova parcela foi implantada e para o Canal da Cosipa duas parcelas.

A quantidade de propágulos reservados inicialmente para o replantio foi insuficiente para uma demanda imprevista como a ocorrida, tendo sido realizada uma segunda coleta /mensuração/ análise química para os novos propágulos originados tanto das áreas da Baixada como da Ilha do Cardoso, repetindo-se todos os passos da primeira etapa. 
É interessante destacar que os propágulos plantados da primeira vez praticamente não apresentavam enraizamento e folhas; o plantio de reposição feito com os propágulos reservados (mantidos em balde com umidificação) apresentavam bom enraizamento e/ou brotações de folhas ou mesmo ramos com vários pares de folhas; já para o plantio realizado com os propágulos da segunda coleta, havia uma situação mista, com parte dos propágulos sem raízes e folhas e parte apresentando tais estruturas.

\section{- Croqui das áreas de amostragem}

Para ilustrar a disposição das parcelas de inventário, matrizes e plantio nas áreas de amostragem, as Figuras 36 a 39 apresentam os croquis das áreas.

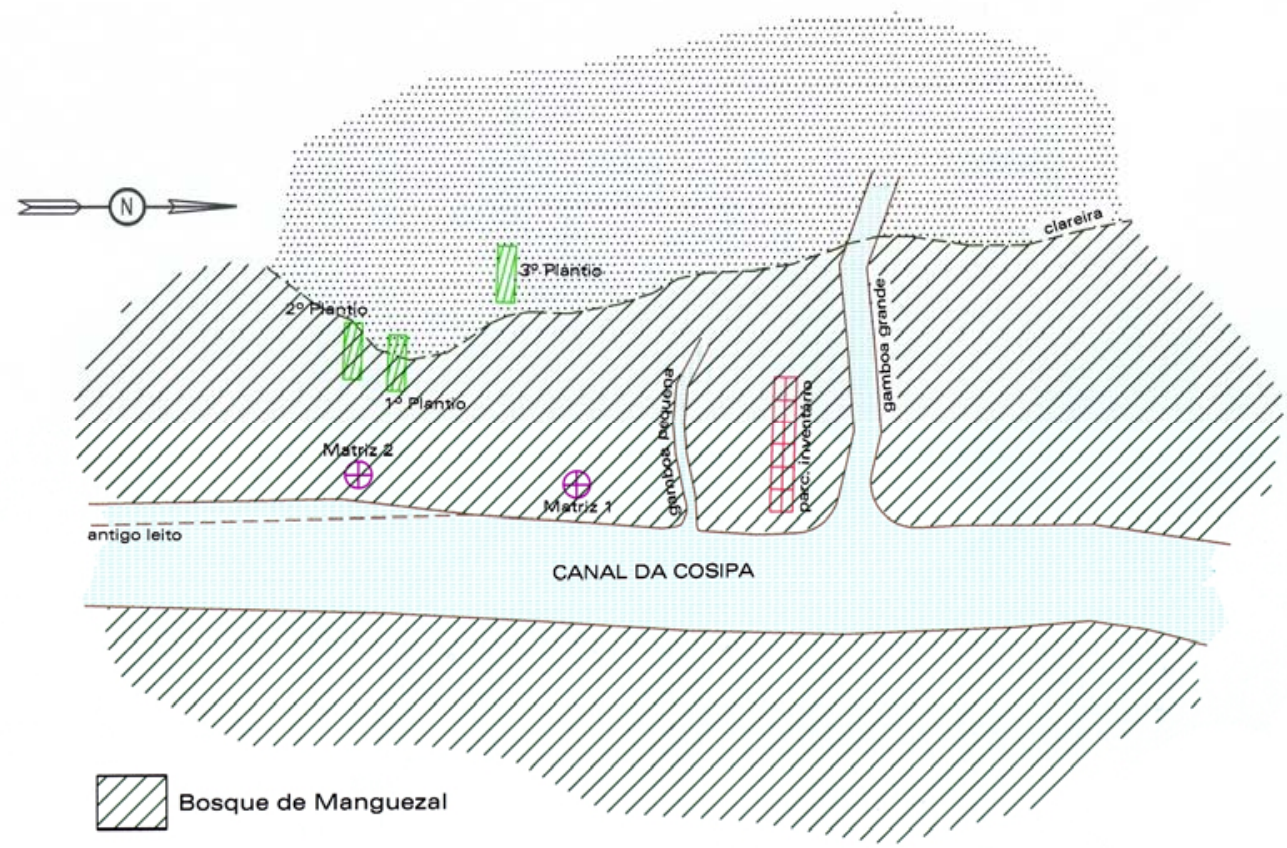

Figura 36 - Croqui da área de amostragem implantada no Canal da Cosipa 


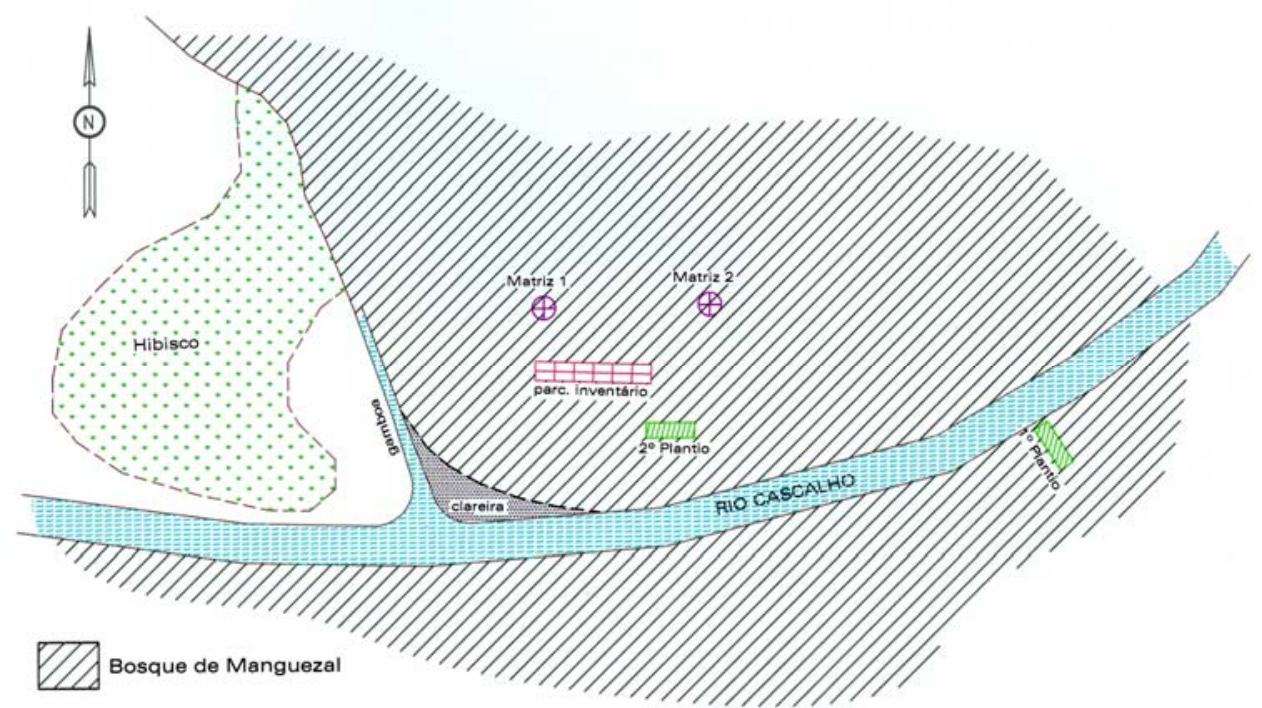

Figura 37 - Croqui da área de amostragem implantada no Rio Cascalho

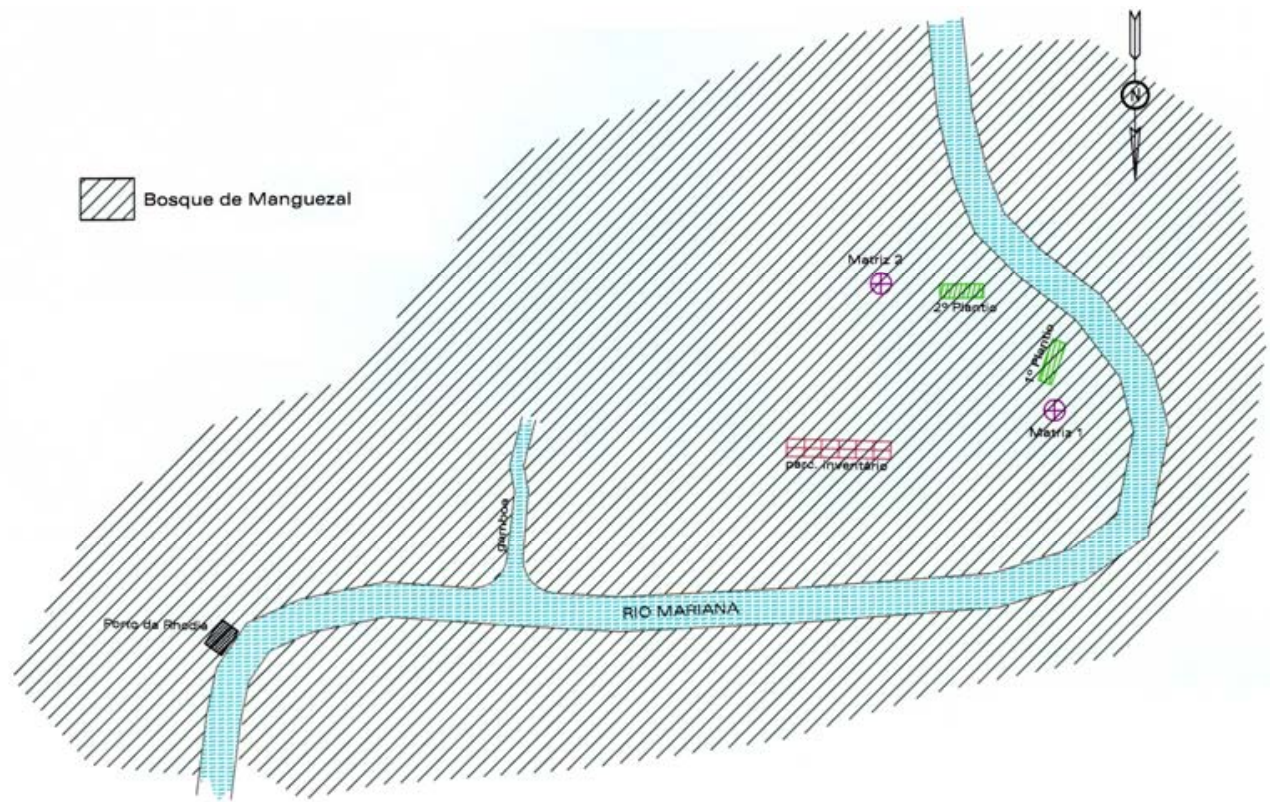

Figura 38 - Croqui da área de amostragem implantada no Rio Mariana 


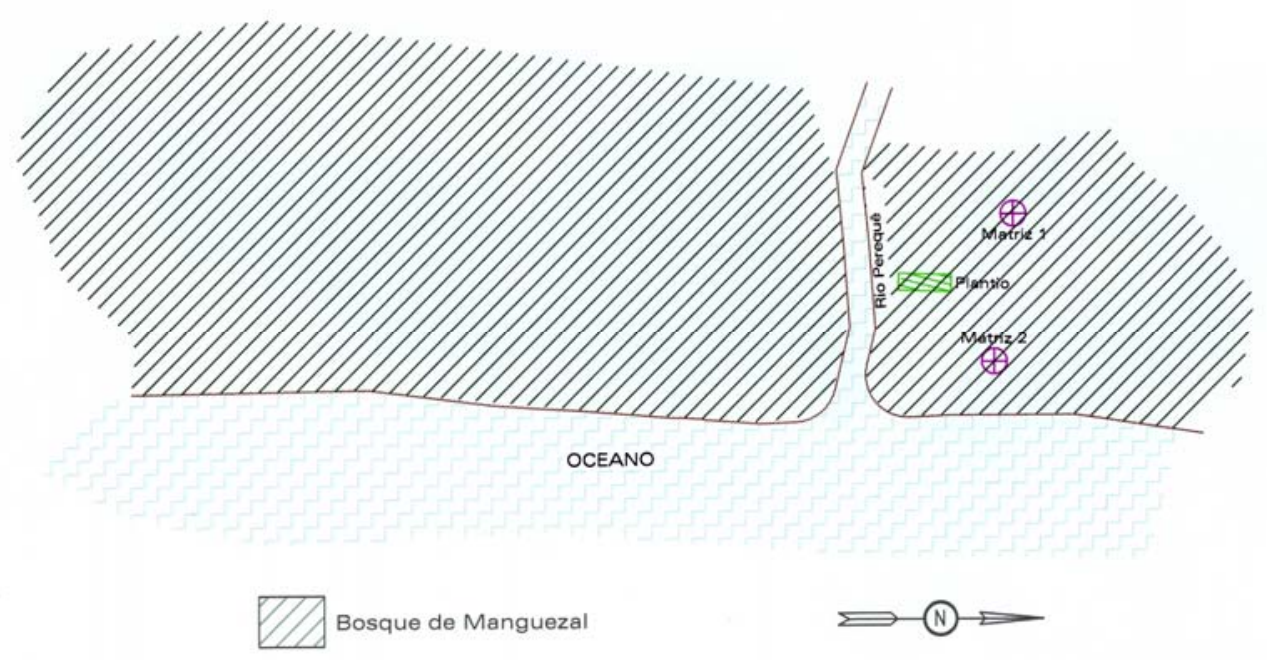

Figura 39 - Croqui da área de amostragem implantada na Ilha do Cardoso

- Coleta de material botânico para análises químicas

Coleta de mudas

A avaliação da contaminação por metais nos propágulos foi feita antes e após o plantio. Amostras compostas de propágulos coletados em cada área e, posteriormente, amostras compostas das mudas desenvolvidas no plantio, foram enviadas para análises químicas.

As amostras de propágulos incluíram vinte propágulos de variadas dimensões e alguns contendo algumas raízes e folhas, que formaram um lote único enviado ao laboratório para realização das análises. As amostras de mudas foram coletadas em campo, sendo os indivíduos remanescentes do plantio arrancados (mantendo sua identificação), lavados levemente com esponja (retirada de restos de solo) e feitas as mensurações e observações: altura da muda $(\mathrm{m})$, diâmetro do colo $(\mathrm{cm})$, número de folhas, número de ramos, enraizamento, Massa úmida (g). Estas foram acondicionadas individualmente em sacos plásticos reidentificados para transporte. 
Devido às grandes perdas de material nas parcelas de plantio, quando o número de mudas remanescentes do plantio não foi suficiente para compor a quantidade desejada para realização das análises, mudas da regeneração natural, com desenvolvimento semelhante àquele das mudas do plantio $\mathrm{e}$ presentes nas imediações desta parcela, foram coletadas para completar o número de amostras.

As Figuras 40 e 41 ilustram o processo de arrancamento na área de plantio e as mudas obtidas.

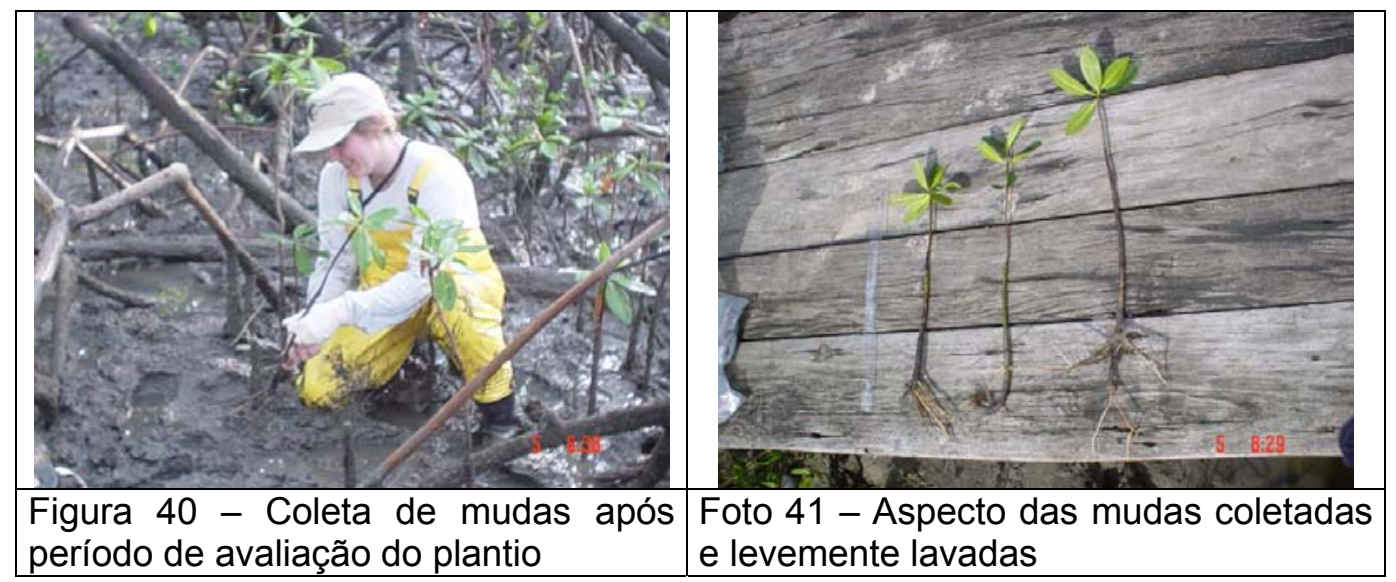

Coleta de folhas

A presença de metais na árvore matriz (indivíduo adulto) foi avaliada nas folhas. Cinco amostras de folhas/matriz (coletada uma única vez, na última campanha de campo, após 2 anos do início das mensurações) foi enviada para análise química. Para coleta foi selecionado um galho na posição mediana da altura da copa (foi anotado a altura do galho coletado), cuja avaliação visual indicou existência de folhas em abundância e na maioria sadias. 
Após corte, com podão, da extremidade do galho selecionado (no comprimento do terço mais externo), os ramos foram separados e contados e para cada ramo foi contado o número de folhas.

Feitas as contagens e observações da sanidade das folhas, cada amostra foi acondicionada em saco plástico identificado e tarado para pesagem (Massa úmida, em g). Os sacos com as amostras foram mantidos abertos e em local sombreado para evitar acúmulo de água.

As Figuras 42 e 43 detalham o processo de poda do galho com podão e a situação da copa destacando o galho podado.

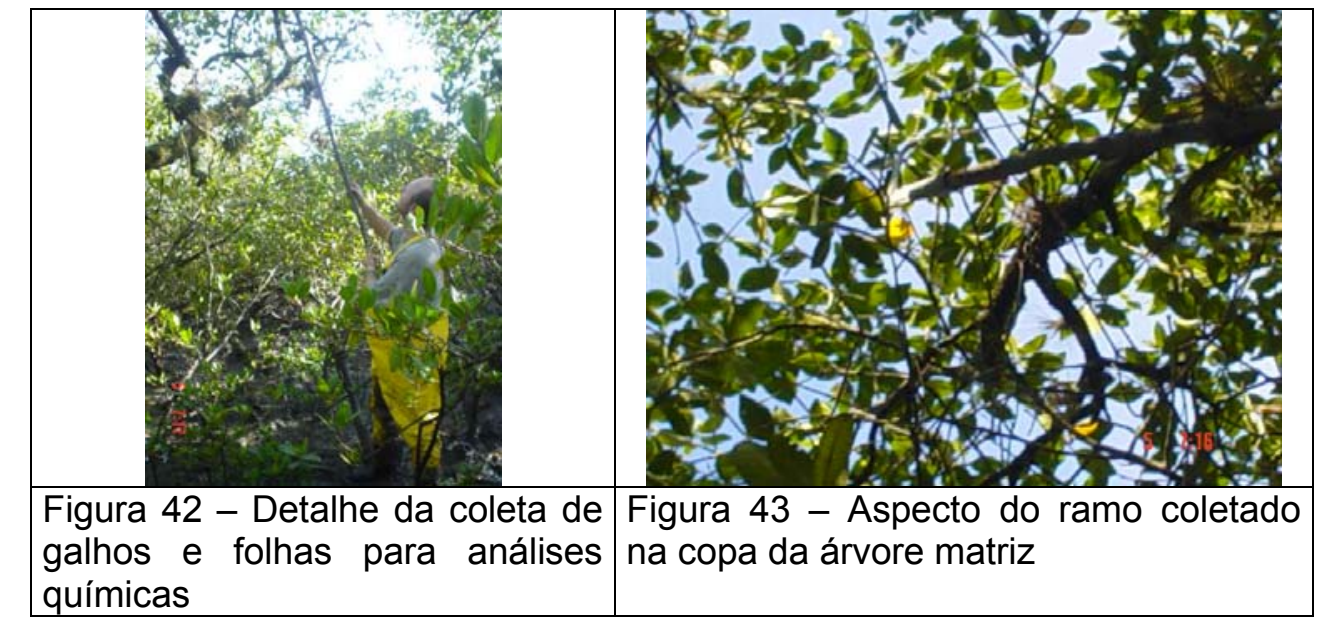

- Conversão de Massa úmida para Massa seca

Uma amostra de propágulos foi separada para secagem e avaliação da conversão do Massa úmida (MU) para Massa seca (MS). Logo após a coleta os propágulos foram pesados (g), mensurados (mesmas medidas que os propágulos do plantio) e acondicionados em saco plástico mantido aberto para evitar acúmulo de água durante o transporte. 
Para facilitar a liberação de água durante a secagem, os propágulos foram levemente amassados com martelo de madeira, espalhados sobre recipiente de alumínio com as plaquetas de identificação amarradas. A secagem foi realizada em estufa até peso constante $(\mathrm{g})$ e o resultado desta última pesagem foi considerado a MS do material.

A conversão MU : MS foi calculada em porcentagem, da seguinte forma:

$$
M U: M S=\frac{(M S / M U)}{100}
$$

- Análises químicas dos propágulos, mudas e folhas

Para a realização das análises químicas da concentração de metais no material botânico foi feita uma parceria com o Departamento de Química da ESALQ/USP para onde as amostras coletadas foram enviadas. A responsável pelas análises foi a Eng ${ }^{a}$. Química Ana Paula Contador Packer.

Em laboratório, as amostras de propágulos, mudas e folhas, recémcoletadas em campo e transportadas sob sombra, foram lavadas com água de torneira e enxaguadas com água destilada. Após a lavagem, os propágulos, e quando necessário também as mudas, foram levemente amassadas com martelo (para rompimento dos tecidos, facilitando a saída da água durante a secagem) e colocadas em formas metálicas; já as folhas foram colocadas em saco de papel levados à estufa para secagem.

A secagem foi realizada em estufa com circulação forçada de ar, sob temperatura contínua $\left(60^{\circ} \mathrm{C}\right)$ até peso constante. Em seguida cada lote de propágulos foi triturado conjuntamente e para as mudas e folhas, a moagem foi realizada individualmente. A trituração foi feita em moinho elétrico, sendo o material armazenado em sacos plásticos. 
De cada amostra foi preparado um extrato (digestão com $\mathrm{HNO}_{3}$ e $\mathrm{H}_{2} \mathrm{O}_{2}$ em frascos de Teflon fechados em forno de microondas). Deste frasco transferiu-se $500 \mathrm{mg}$ de cada amostra para frascos de $100 \mathrm{~mL}$, adicionou-se $5 \mathrm{~mL}$ de $\mathrm{HNO}_{3} 65 \%$ p.a. Após 24 horas adicionou-se mais $2 \mathrm{~mL}$ de $\mathrm{H}_{2} \mathrm{O}_{2}$, tampou-se o sistema e os frascos foram colocados no forno de microondas, variando-se a pressão de 60, 120 PSI por 10 e 50 minutos, respectivamente.

Após a digestão o volume foi completado para $50 \mathrm{~mL}$ com água destilada e fez-se a leitura do extrato por espectrometria de massas com fonte de plasma (ICP-MS) para a determinação da concentração de metais.

Para cada metal, o método de análise permitiu um valor de Limite de Detecção (LD) $)^{8}$ variável de acordo com o metal analisado.

- $\quad$ Coleta e análises químicas de amostras de solo

Para a coleta e análises químicas de solo foi feita uma parceria com o Departamento de Solos da ESALQ/USP - Grupo de estudos de solo de Manguezais, coordenado pelo Prof. Dr. Pablo Vidal Torrado, sendo que tanto as coletas como as análises das amostras foram realizadas por Maria Luiza de Souza Silva, que utilizou as mesmas áreas de estudo para elaboração da tese de Doutorado intitulada: "Biogeoquímica de elementos traço em solos de sistemas estuarinos: manguezais do Estado de São Paulo (Brasil) e marismas da Galícia (Espanha)"9. Parte das análises constantes desta tese foram então consideradas no presente trabalho, ou seja, os resultados que se referem à caracterização geral do solo e verificação dos níveis de base dos elementos traço nos solos de Manguezal para as mesmas áreas aqui enfocadas.

\footnotetext{
${ }^{8} \mathrm{O}$ limite de detecção (LD) de uma técnica instrumental é um número expresso em unidades de concentração (ou quantidade) de um material analisado que descreve a concentração derivada da menor medida que pode ser detectada, com razoável certeza, por um dado procedimento analítico. Por definição, o LD é considerado como 3 vezes o desvio padrão $(3 \times \sigma)$ de 11 medidas do branco das amostras em concentração.
}

${ }^{9}$ Silva (2005). 
As amostras de solo foram coletadas nas áreas da Baixada Santista e na Ilha do Cardoso, em condições de maré baixa, sendo avaliados três pontos de amostragem no Canal da Cosipa, um ponto no Rio Cascalho, um no Rio Mariana e quatro na llha do Cardoso. Nas áreas com avaliação de mais de um ponto, um deles foi tomado contíguo ou interno às parcelas do presente estudo.

A coleta foi realizada empregando amostradores específicos para solos inundados, com profundidade máxima de $90 \mathrm{~cm}(0-5 ; 5-10 ; 10-15 ; 15-20 ; 20-25$; $25-40 \mathrm{~cm}$ e Gley $\cong 60-90 \mathrm{~cm}$ ). No momento da amostragem foram medidos o potencial redox $(\mathrm{Eh}-\mathrm{mV})$ e $\mathrm{pH}$ a $25^{\circ} \mathrm{C}$, com o auxílio de aparelho portátil.

As Figuras 44 e 45 ilustram a coleta de amostras de solo.

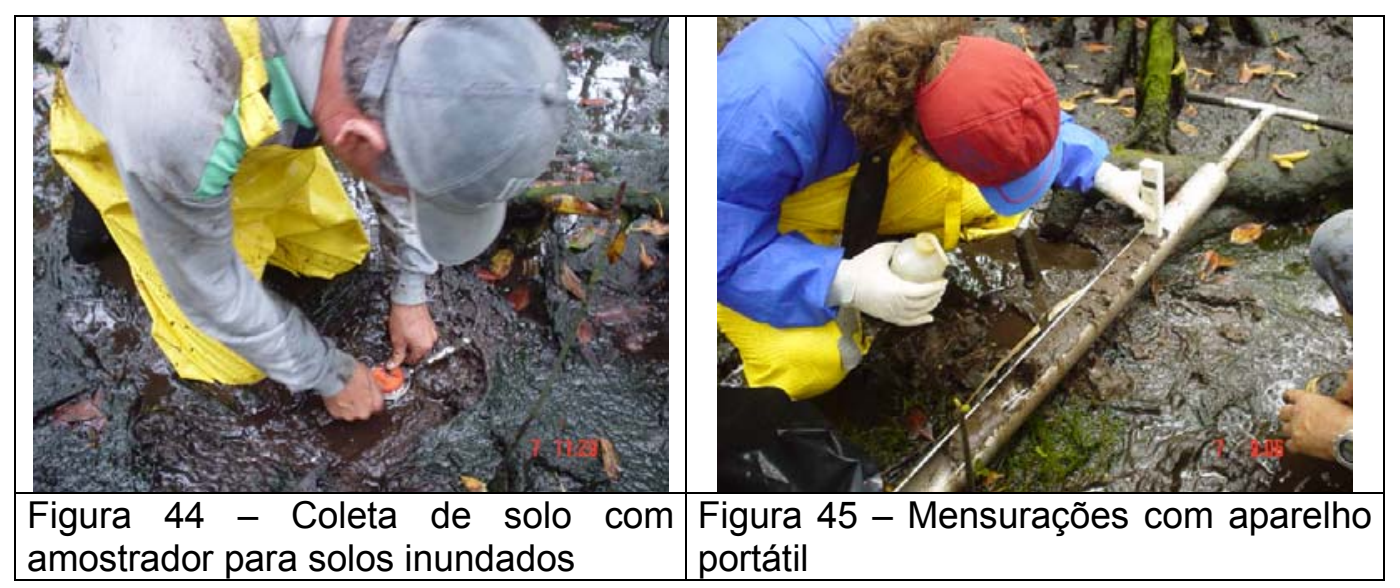

Dentre os dados e resultados obtidos tem-se a determinação do $\mathrm{pH}$, potencial Redox (Eh), conteúdo de carbono orgânico total (TOC), S total, N total e conteúdo total e fracionamento dos elementos traço ${ }^{10}$. Os elementos traço avaliados foram: V (Vanádio), Cr (Cromo), Co (Cobalto), Ni (Níquel), Cu (Cobre), Zn (Zinco), As (Arsênio), Ba (Bário), Pb (Chumbo) e Mo (Molibidênio).

Para maior detalhamento sobre a metodologia de coleta e análise das amostras vide Silva (2005). 


\section{- Análises estatísticas dos dados}

Os dados obtidos foram condensados em planilhas eletrônicas e analisados empregando o pacote estatístico SAS - Statistical Analysis System. Foram realizadas análises de variância e quando houve significância, fez-se o Teste de Tukey. A análise de variância considera os seguintes parâmetros:

Média - Média do parâmetro avaliado para as repetições.

F - Valor que indica a significância do tratamento.

$\operatorname{Pr}>$ F - Probabilidade das diferenças obtidas entre os tratamentos ser devida ao efeito do tratamento realizado, podendo ser:

** - significativo a $1 \%$ de probabilidade $(\operatorname{Pr} \leq 0,01)$

* - significativo a 5\% de probabilidade $(\operatorname{Pr} 0,01>\operatorname{Pr}>0,05)$

$$
\text { ns - não significativo }(\operatorname{Pr} \geq 0,05)
$$

Para alguns parâmetros as repetições não foram suficientes para possibilitar a realização de análises estatísticas, especialmente devido a perda de dados com mortalidade, análises químicas com resultado LD - abaixo do limite de detecção ou outros fatos similares. Assim, algumas análises foram feitas sem a aplicação de cálculos estatísticos.

Destaca-se ainda que a grande maioria das análises foi feita empregando os dados originais, mas para alguns parâmetros, visando minimizar os valores do coeficiente de variação, os dados foram transformados antes da realização da análise de variância.

\footnotetext{
${ }^{10}$ Os resultados referentes ao fracionamento dos elementos traço não serão considerados para o presente estudo pois se referem mais especificamente às avaliações da biogeoquímica do solo, não enfocada no trabalho em tela.
} 


\section{- Observação adicional : Ataque de pragas - Lagartas}

Durante a coleta de propágulos em que se percorreu a região da Baixada para definição das áreas de amostragem foi casualmente encontrada, em um trecho de Manguezal ao longo do Rio Cascalho (Cubatão), uma grande concentração de lagartas, que foi constatada como a praga que vinha comprometendo grandes áreas de Manguezal na região e que até aquele momento não havia ainda sido encontrada ${ }^{11}$.

Assim, vários indivíduos jovens e adultos foram coletados para posterior identificação. Para coleta e manutenção das lagartas vivas foram cortadas pontas de galhos onde estas estavam se alimentando das folhas, e os ramos colocados em recipiente fechado, porém com entrada de ar. A área de coleta e lagartas foram fotografadas.

Os recipientes contendo os indivíduos foram enviados ao Departamento de Entomologia da ESALQ/USP para identificação da espécie, que foi feita pelo Prof. Dr. Ivôneo Berti Filho e confirmada por especialistas de Brasília.

As lagartas foram transferidas para recinto apropriado e alimentadas para obtenção de mariposas adultas (machos e fêmeas) o que possibilitou a identificação da espécie.

\footnotetext{
${ }^{11}$ Alguns anos antes começaram a aparecer trechos de Manguezal, espalhados por toda região, com as árvores desfolhadas e secas, mas não havia sido encontrada a causa de tal problema. Supunha-se ser efeito de contaminação ou ataque de alguma praga, mas que até aquele momento não havia sido comprovada.
} 


\subsection{Cronologia dos eventos}

As Tabelas 5 a 7 relacionam as datas das atividades realizadas.

Tabela 5. Data de coleta e mensurações de propágulos, plantio e avaliações

\begin{tabular}{cccccc}
\hline Local & Coleta & Mensurações & Plantio & $\mathbf{1}^{\circ}$ avaliação & $\mathbf{2}^{\circ}$ avaliação \\
\hline \multirow{2}{*}{ RC } & $1^{\circ} 26 / 03 / 02$ & $09 / 04 / 02$ & $1^{\circ} 25 / 04 / 02$ & $10 / 02 / 03$ & Não realizada \\
& $2^{\circ} 18 / 01 / 03$ & $05 / 02 / 03$ & $2^{\circ} 10 / 02 / 03$ & $11 / 08 / 03$ & $16 / 03 / 04$ \\
RM & $1^{\circ} 27 / 03 / 02$ & $10 / 04 / 02$ & $1^{\circ} 26 / 04 / 02$ & $10 / 02 / 03$ & Não realizada \\
& $2^{\circ} 18 / 01 / 03$ & $06 / 02 / 03$ & $2^{\circ} 10 / 02 / 03$ & $12 / 08 / 03$ & Não realizada \\
& $1^{\circ} 26 / 03 / 02$ & $1 / 04 / 02$ & $1^{\circ} 25 / 04 / 02$ & $25 / 07 / 02$ & Não realizada \\
CC & Propág. reserva & Propág. reserva & $2^{\circ} 25 / 07 / 02$ & $10 / 02 / 03$ & Não realizada \\
& $2^{\circ} 18 / 01 / 03$ & $07 / 02 / 03$ & $3^{\circ} 10 / 02 / 03$ & $13 / 08 / 03$ & $16 / 03 / 04$ \\
IC & $1^{\circ} 01 / 04 / 02$ & $01 / 04 / 02$ & $1^{\circ} 02 / 04 / 02$ & $05 / 12 / 03$ & Não realizada \\
& $2^{\circ} 25 / 01 / 03$ & $07 / 02 / 03$ & $2^{a}$. coleta realizada para replantio na Bx. Santista \\
\hline
\end{tabular}

Obs.: originalmente estavam previstas 4 avaliações semestrais, porém devido à alta mortalidade e necessidade de replantio não houve tempo hábil para mais de duas avaliações.

Tabela 6. Data da implantação e avaliações do inventário e matriz

\begin{tabular}{|c|c|c|}
\hline Local & Parcela de inventário & Parcela de árvore matriz \\
\hline RC & $\begin{array}{c}\text { Implantação / } 1^{\circ} \mathrm{Av} .-01 / 07 / 02 \\
2^{\circ} \mathrm{Av} .-18 / 01 / 03 \\
3^{\circ} \mathrm{Av} .-11 / 08 / 03 \\
4^{\circ} \mathrm{Av} .-17 / 03 / 04\end{array}$ & $\begin{array}{c}\text { Implantação / } 1^{\circ} \mathrm{Av} .-27 / 04 / 02 \\
2^{\circ} \mathrm{Av} .-18 / 01 / 03 \\
3^{\circ} \mathrm{Av} .-11 / 08 / 03 \\
4^{\circ} \mathrm{Av} .-17 / 03 / 04\end{array}$ \\
\hline RM & $\begin{array}{c}\text { Implantação / } 1^{\circ} \mathrm{Av} .-03 / 07 / 02 \\
2^{\circ} \mathrm{Av} .-17 / 01 / 03 \\
3^{\circ} \mathrm{Av} .-12 / 08 / 03 \\
4^{\circ} \mathrm{Av} .-18 / 03 / 04\end{array}$ & $\begin{array}{c}\text { Implantação / } 1^{\circ} \mathrm{Av} .-26 / 04 / 02 \\
2^{\circ} \mathrm{Av} .-17 / 01 / 03 \\
3^{\circ} \mathrm{Av} .-12 / 08 / 03 \\
4^{\circ} \mathrm{Av} .-18 / 03 / 04\end{array}$ \\
\hline CC & $\begin{array}{c}\text { Implantação / } 1^{\circ} \mathrm{Av} .-02 / 07 / 02 \\
2^{\circ} \mathrm{Av} .-15 / 01 / 03 \\
3^{\circ} \mathrm{Av} .-13 / 08 / 03 \\
4^{\circ} \mathrm{Av} .-16 / 03 / 04\end{array}$ & $\begin{array}{c}\text { Implantação / } 1^{\circ} \mathrm{Av} .-25 / 04 / 02 \\
2^{\circ} \mathrm{Av.}-15 / 01 / 03 \\
3^{\circ} \mathrm{Av} .-13 / 08 / 03 \\
4^{\circ} \mathrm{Av} .-16 / 03 / 04\end{array}$ \\
\hline IC & --- & --- \\
\hline
\end{tabular}

Nota: Av. = Avaliação ; Na IC não houve implantação de parcela de inventário e de matriz. 
Tabela 7. Data da coleta de amostras de mudas, folhas e solo

\begin{tabular}{ccc}
\hline Local & Coleta de mudas I folhas & Coleta de solo \\
\hline RC & $16 / 03 / 2004$ & $05 / 03 / 2003$ \\
RM & $16 / 03 / 2004$ & $10 / 09 / 2003$ \\
CC & $16 / 03 / 2004$ & $05 / 03 / 2003$ \\
IC & $05 / 12 / 2003$ & $02 / 04 / 2002$ \\
\hline
\end{tabular}

Data da secagem de propágulos (avaliação conversão MU:MS) - 18 a 22/04/02.

Data da coleta de lagartas para identificação da espécie - 18/01/03. 


\section{RESULTADOS E DISCUSSÃO}

\subsection{Fotointerpretação digital}

A fotointerpretação digital foi feita para um raio de $1 \mathrm{Km}$ no entorno das áreas de amostragem com o objetivo de avaliar as condições da região onde estas estão inseridas. As Figuras 46 a 49 apresentam, para cada área, a aerofotografia com destaque do ponto de amostragem e os resultados da fotointerpretação digital destacando uso do solo e cobertura vegetal. 
Das figuras apresentadas verifica-se sobre a região em que se inserem as áreas de amostragem, que para o Rio Mariana e Rio Cascalho os locais avaliados estão próximos de áreas de uso intensivo caracterizadas como ocupação urbana, recebendo grande influência deste fator de tensão ambiental associado também à contaminação das fontes industriais inseridas nestas áreas ou mesmo um pouco deslocadas. Para o Canal da Cosipa não há, no raio amostrado, áreas de uso intensivo urbanas, porém os tensores ambientais estão associados ao complexo industrial da Cosipa e ao trânsito de embarcações.

O padrão de cobertura do solo caracterizado como bancos de areia aparece com expressão nas áreas da Baixada, sendo resultado tanto da ação natural (deposição de sedimentos pelas marés), quanto pela ação humana, com a supressão de áreas de Restinga, ou ainda, como no caso do Canal da Cosipa, pode ser resultado da deposição de material residual das dragagens do canal.

É interessante notar que na região do Rio Cascalho e do Canal da Cosipa a situação do relevo é tal que as formações de Manguezal predominam acompanhando os cursos d'água e estendendo-se mais para o interior, nas áreas baixas influenciadas pelas marés. Já para o Rio Mariana, os bosques de Manguezal ocupam áreas mais estreitas acompanhando o curso d’água que serpenteia no fundo do vale e, nas áreas mais altas aparece a Mata (que apresenta clareiras associadas especialmente a intervenções humanas) ou ainda dá-se a ocupação massiva caracterizada pela urbanização.

Já na llha do Cardoso, o Rio Perequê apresenta trechos de Manguezal envoltos por Restinga ou Mata densa, indo desembocar na Praia. O ponto de amostragem localiza-se próximo de áreas de uso intensivo caracterizadas pelas instalações do alojamento, museu, enfim, voltadas à administração, ensino e pesquisa na Unidade de Conservação. 


\subsection{Coleta e mensuração de propágulos}

\section{Florescimento e frutificação}

Sabe-se que a produção de propágulos de $R$. mangle dá-se de forma sazonal, por vezes variando localmente dentro de uma região e podendo também apresentar periodicidade variável. Assim, um dos critérios de seleção da área de amostragem foi a presença de árvores produzindo propágulos no momento do início do trabalho, o que possibilitaria a coleta destes para realização do plantio e também a implantação das parcelas de árvore matriz.

Assim, apesar de não se tratar de um trabalho voltado à fenologia foram feitas observações, em todas as campanhas de campo, sobre o florescimento e frutificação das árvores das parcelas de matriz e daquelas presentes na parcela de inventário.

Os dados obtidos, apresentados nas Tabelas 8 e 9 a seguir, não podem ser considerados representativos ${ }^{12}$, porém foram apresentados visando ilustrar a situação das áreas de amostragem em termos de produção de propágulos durante o período de desenvolvimento do trabalho, e também apresentar as informações obtidas, de forma indireta, sobre tal assunto.

\footnotetext{
${ }^{12}$ A não representatividade deve-se a fatores como: poucas repetições (pequeno número de árvores avaliado), curto período de tempo das observações (apenas dois anos, não incluindo sazonalidade da reprodução), avaliação de pontos isolados e não de exemplares espalhados nas diferentes condições da região, falta de sistematização na coleta de dados, entre outros.
} 
Tabela 8. Observações de florescimento e frutificação das árvores das parcelas matriz nas áreas da Baixada Santista

\begin{tabular}{|c|c|c|c|c|}
\hline \multirow{2}{*}{$\begin{array}{c}\text { Data da } \\
\text { avaliação }\end{array}$} & \multicolumn{2}{|c|}{ Matriz 1} & \multicolumn{2}{|c|}{ Matriz 2} \\
\hline & Floração & Frutificação & Floração & Frutificação \\
\hline \multicolumn{5}{|c|}{ Canal da Cosipa } \\
\hline $1^{\text {a }} \cdot 25 / 04 / 02$ & apresenta & apresenta & -- & apresenta \\
\hline $2^{\mathrm{a}} \cdot 15 / 01 / 03$ & -- & -- & -- & -- \\
\hline $3^{a} .13 / 08 / 03$ & -- & -- & -- & -- \\
\hline $4^{\mathrm{a}} \cdot 16 / 03 / 04$ & -- & apresenta & -- & apresenta \\
\hline \multicolumn{5}{|c|}{ Rio Cascalho } \\
\hline $1^{\text {a }} \cdot 27 / 04 / 02$ & -- & apresenta & -- & apresenta \\
\hline $2^{\mathrm{a}} \cdot 18 / 01 / 03$ & -- & -- & -- & -- \\
\hline $3^{a} .11 / 08 / 03$ & -- & -- & -- & -- \\
\hline $4^{a} \cdot 17 / 03 / 04$ & -- & apresenta & -- & apresenta \\
\hline \multicolumn{5}{|c|}{ Rio Mariana } \\
\hline $1^{\text {a }} \cdot 27 / 04 / 02$ & -- & apresenta & -- & apresenta \\
\hline $2^{\mathrm{a}} \cdot 18 / 01 / 03$ & -- & apresenta & -- & apresenta \\
\hline $3^{\text {a }} .11 / 08 / 03$ & -- & apresenta & -- & apresenta \\
\hline $4^{a} .17 / 03 / 04$ & -- & apresenta & apresenta & apresenta \\
\hline
\end{tabular}

Dos resultados obtidos pode-se inferir que a floração pode ocorrer no mesmo período que a frutificação, mas varia entre árvores e é mais comum encontrar matrizes apenas com propágulos, uma vez que devido à viviparidade estes ocorrem presos à matriz por mais tempo do que as flores.

Verificou-se também que há uma variação entre as áreas amostradas já que o padrão de florescimento e frutificação foi similar para o Canal da Cosipa e Rio Cascalho (aproximadamente anual), provavelmente por serem áreas mais próximas entre si e apresentarem bosque mais alterado, enquanto que o Rio Mariana, em local mais distante das outras duas áreas e com bosque mais desenvolvido, apresentou frutificação contínua pelo período de dois anos da avaliação. 
Tabela 9. Observações de florescimento e frutificação das árvores das parcelas de inventário nas áreas da Baixada Santista

\begin{tabular}{|c|c|c|c|c|}
\hline \multirow{3}{*}{$\begin{array}{c}\text { Data da } \\
\text { avaliação }\end{array}$} & \multicolumn{4}{|c|}{$\mathbf{N}^{\circ}$. de plantas } \\
\hline & \multicolumn{2}{|c|}{ Floração } & \multicolumn{2}{|c|}{ Frutificação } \\
\hline & R. mangle & A. shaueriana & R. mangle & A. shaueriana \\
\hline \multicolumn{5}{|c|}{ Canal da Cosipa } \\
\hline \multicolumn{5}{|c|}{ (No. Total de plantas avaliadas $=5 \leftrightarrow 5 \rightarrow R$. mangle e $0 \rightarrow A$. shaueriana) } \\
\hline $1^{\text {a }} .02 / 07 / 02$ & 0 & -- & 0 & -- \\
\hline $2^{a} \cdot 15 / 01 / 03$ & 0 & -- & 1 & -- \\
\hline $3^{a} \cdot 13 / 08 / 03$ & 0 & -- & 1 & -- \\
\hline $4^{\mathrm{a}} \cdot 16 / 03 / 04$ & 1 & -- & 3 & -- \\
\hline \multicolumn{5}{|c|}{ Rio Cascalho } \\
\hline \multicolumn{5}{|c|}{ (No. Total de plantas avaliadas $=10 \leftrightarrow 1 \rightarrow R$. mangle e $9 \rightarrow A$. shaueriana) } \\
\hline $1^{\text {a }} .01 / 07 / 02$ & 0 & 0 & 0 & 0 \\
\hline $2^{a} .18 / 01 / 03$ & 0 & 6 & 3 & 1 \\
\hline $3^{a} .11 / 08 / 03$ & 0 & 0 & 0 & 0 \\
\hline $4^{\mathrm{a} .} .17 / 03 / 04$ & 0 & 9 & 0 & 0 \\
\hline \multicolumn{5}{|c|}{ Rio Mariana } \\
\hline \multicolumn{5}{|c|}{ (No. Total de plantas avaliadas $=22 \leftrightarrow 19 \rightarrow R$. mangle e $3 \rightarrow A$. shaueriana) } \\
\hline $1^{\text {a } . ~} 03 / 07 / 02$ & 0 & 0 & 0 & 0 \\
\hline $2^{a} .17 / 01 / 03$ & 0 & 0 & 4 & 1 \\
\hline $3^{a} .12 / 08 / 03$ & 0 & 0 & 1 & 1 \\
\hline $4^{\mathrm{a}} \cdot 18 / 03 / 04$ & 0 & 0 & 12 & 1 \\
\hline
\end{tabular}

--- - espécie ausente na parcela da área amostrada.

Nas parcela de inventário observou-se que há variação entre árvores e entre áreas no que se refere à frutificação, especialmente para o $R$. mangle, cujo número de indivíduos frutificando é bem maior do que o da $A$. shaueriana.

À semelhança do que ocorreu com as árvores matriz (porém a informação aqui foi obtida para um maior número de árvores - repetições), o Rio Mariana foi o que apresentou a melhor produção de frutos no período das avaliações. Adicionalmente, no Rio Mariana observou-se uma tendência à sazonalidade anual para a frutificação. 


\section{Características do propágulo nas áreas de amostragem}

Com os dados mensurados nos propágulos foi realizada análise estatística visando a comparação das áreas, para identificar se estas estariam produzindo propágulos com características (dimensões e massa) diferenciadas.

Na seqüência foi feita também a comparação entre as características dos propágulos e a concentração de metais presentes nestes, para cada área, visando relacionar os níveis de contaminação dos propágulos e as características dos propágulos produzidos no local.

Assim, na Tabela 10 são apresentados os resultados das análises da dimensão dos propágulos / área.

Tabela 10. Avaliação das medidas dos propágulos de R. mangle

\begin{tabular}{|c|c|c|c|c|c|c|}
\hline Parâmetro / unidade & \multicolumn{3}{|c|}{$\begin{array}{l}\text { imensão de propágulos / área } \\
\text { Análise de Variância }\end{array}$} & \multicolumn{3}{|c|}{$\begin{array}{c}\text { Teste de Tukey } \\
(5 \% \text { de probabilidade })\end{array}$} \\
\hline Massa úmida (g) & 29,66 & 18,34 & 0,0001 ** & $\begin{array}{l}\text { IC } \\
\text { CC } \\
\text { RM } \\
\text { RC }\end{array}$ & $\begin{array}{l}34,20 \\
32,58 \\
28,10 \\
26,45\end{array}$ & $\begin{array}{l}a \\
a \\
b \\
b\end{array}$ \\
\hline $\begin{array}{l}\text { Diâmetro médio do centro } \\
\text { do propágulo }(\mathrm{mm})\end{array}$ & 12,14 & 33,61 & 0,0001 ** & $\begin{array}{l}\text { CC } \\
\text { IC } \\
\text { RM } \\
\text { RC }\end{array}$ & $\begin{array}{l}15,32 \\
10,98 \\
10,49 \\
10,11\end{array}$ & $\begin{array}{l}a \\
b \\
b \\
b\end{array}$ \\
\hline $\begin{array}{l}\text { Diâmetro médio da base } \\
\text { do propágulo }(\mathrm{mm})\end{array}$ & 12,33 & 1,95 & $0,1195 \mathrm{~ns}$ & $\begin{array}{l}\text { IC } \\
\text { CC } \\
\text { RM } \\
\text { RC }\end{array}$ & $\begin{array}{l}12,67 \\
12,37 \\
12,35 \\
12,18\end{array}$ & $\begin{array}{c}a \\
a b \\
a b \\
b\end{array}$ \\
\hline $\begin{array}{l}\text { Diâmetro médio do ápice } \\
\text { do propágulo }(\mathrm{mm})\end{array}$ & 7,21 & 3,86 & $0,0093 * *$ & $\begin{array}{l}\text { IC } \\
\text { CC } \\
\text { RM } \\
\text { RC }\end{array}$ & $\begin{array}{l}7,44 \\
7,26 \\
7,24 \\
7,06\end{array}$ & $\begin{array}{c}a \\
a b \\
a b \\
b\end{array}$ \\
\hline $\begin{array}{l}\text { Comprimento total do } \\
\text { propágulo }(\mathrm{cm})\end{array}$ & 33,69 & 2,10 & $0,0992 \mathrm{~ns}$ & $\begin{array}{l}\text { IC } \\
\text { RM } \\
\text { CC } \\
\text { RC }\end{array}$ & $\begin{array}{l}34,29 \\
34,10 \\
33,97 \\
32,77\end{array}$ & $\begin{array}{l}\mathrm{a} \\
\mathrm{a} \\
\mathrm{a} \\
\mathrm{a}\end{array}$ \\
\hline
\end{tabular}

Legenda: Teste de Tukey para comparação de médias entre Áreas:

IC - Ilha do Cardoso; CC - Canal da Cosipa; RM - Rio Marina; RC - Rio Cascalho. 
Para a Massa úmida, cuja média foi propágulos com 29,66 g, a diferença entre áreas é altamente significativa (1\% de probabilidade), com a Ilha do Cardoso apresentando os propágulos mais pesados, seguida do Canal da Cosipa, Rio Mariana e Rio Cascalho. Assim, a área testemunha, com bosque menos alterado, produz propágulos mais pesados, porém esta relação não se verifica entre as áreas da Baixada Santista, uma vez que o Canal da Cosipa (com bosque mais alterado) apresentou propágulos mais pesados que o Rio Mariana (bosque menos alterado dentre as três áreas).

Em relação ao diâmetro, o centro e a base dos propágulos apresentam dimensões parecidas, afinado no ápice. O diâmetro do centro e ápice apresentam diferenças altamente significativas entre áreas, o que não ocorre com o diâmetro da base. Diâmetro do centro e ápice são maiores no Canal da Cosipa e na Ilha do Cardoso, respectivamente. Quanto ao comprimento do propágulo (média de $33,70 \mathrm{~cm}$ ), não houve diferença significativa entre áreas.

\section{$\underline{\text { Características do propágulo e desenvolvimento da muda }}$}

Para os propágulos coletados nas áreas e destinados ao plantio, as medidas dos diâmetros (base, centro e ápice), comprimento e massa úmida foram cruzados com o desenvolvimento das mudas originadas destes propágulos, visando identificar se há algum parâmetro morfológico que condiciona um melhor desenvolvimento da muda. Com esta informação buscava-se recomendar o tipo de propágulo a ser coletado para o plantio, ou seja, direcionar a coleta a propágulos com características propiciadoras de melhor desenvolvimento da muda. Tal informação, seria, em princípio, avaliada por meio de análise de correlação, porém devido à grande mortalidade, a quantidade de mudas obtidas não possibilitou o estudo de correlações (número insuficiente de repetições). Então foi apresentada uma tabela com as características dos propágulos e os parâmetros indicativos do desenvolvimento das mudas remanescentes, para verificar a possibilidade de tendências. 
As Tabelas 11 a 13 a seguir apresentam os parâmetros mensurados nos propágulos e respectivas mudas para o Rio Cascalho, Canal da Cosipa e Ilha do Cardoso. Para o Rio Mariana a avaliação não foi feita pois a mortalidade nesta área foi de $100 \%$.

Tabela 11. Parâmetros avaliados em propágulos e mudas no Rio Cascalho

\begin{tabular}{|c|c|c|c|c|c|}
\hline \multicolumn{6}{|c|}{ Propágulos - mensurações antes do plantio - 05/02/03 } \\
\hline Código & $\begin{array}{l}\text { Massa } \\
\text { Úmida (g) }\end{array}$ & $\begin{array}{c}\text { Comprimento } \\
\text { Total (cm) }\end{array}$ & $\begin{array}{l}\text { Diâmetro do } \\
\text { centro }(\mathrm{mm})\end{array}$ & $\begin{array}{l}\text { Diâmetro da } \\
\text { base (mm) }\end{array}$ & $\begin{array}{l}\text { Diâmetro do } \\
\text { ápice (mm) }\end{array}$ \\
\hline RC RC 9 & 30 & 26,0 & 13,0 & 17,0 & 9,0 \\
\hline RC RC 12 & 20 & 41,0 & 10,5 & 13,0 & 7,5 \\
\hline RC RC 29 & 30 & 30,0 & 13,0 & 15,5 & 8,5 \\
\hline RC RC 30 & 30 & 26,5 & 9,0 & 12,0 & 7,0 \\
\hline RC RC 49 & 20 & 31,0 & 11,0 & 14,5 & 7,5 \\
\hline RC IC 10 & 40 & 28,0 & 14,0 & 14,5 & 9,0 \\
\hline $\mathrm{RC}$ IC 25 & 40 & 30,0 & 9,0 & 11,0 & 7,0 \\
\hline $\mathrm{RC}$ IC 27 & 40 & 28,5 & 12,5 & 13,5 & 7,0 \\
\hline RC IC 33 & 30 & 35,0 & 14,0 & 15,0 & 9,0 \\
\hline RC IC 35 & 40 & 24,0 & 11,0 & 12,0 & 7,0 \\
\hline \multicolumn{6}{|c|}{ Mudas - mensurações no momento do arrancamento - 16/03/04 } \\
\hline Código & $\begin{array}{l}\text { Altura planta } \\
\text { (cm) }\end{array}$ & $\begin{array}{l}\text { Diâmetro do } \\
\text { Colo }(\mathrm{mm})\end{array}$ & $\begin{array}{l}N^{\circ} \text { de } \\
\text { Folhas }\end{array}$ & $\begin{array}{c}N^{\circ} \text { de } \\
\text { Ramos }\end{array}$ & $\begin{array}{l}\text { Presença de } \\
\text { Enraizamento }\end{array}$ \\
\hline $\mathrm{RC} \mathrm{RC} 9$ & 42,0 & 16,5 & 10 & 2 & $\operatorname{Sim}$ \\
\hline RC RC 12 & 72,0 & 12,5 & 4 & 0 & Sim \\
\hline RC RC 29 & 72,0 & 14,0 & 2 & 0 & Sim \\
\hline $\mathrm{RC} \mathrm{RC} 30$ & 70,0 & 14,0 & 4 & 0 & Sim \\
\hline RC RC 49 & 82,0 & 15,0 & 2 & 0 & Sim \\
\hline RC IC 10 & 38,0 & 15,5 & 3 & 0 & Sim \\
\hline RC IC 25 & 51,0 & 12,0 & 4 & 0 & Sim \\
\hline $\mathrm{RC}$ IC 27 & 78,0 & 15,5 & 4 & 0 & Sim \\
\hline RC IC 33 & 82,0 & 16,0 & 2 & 0 & Sim \\
\hline RC IC 35 & 60,0 & 14,0 & 2 & 0 & Sim \\
\hline
\end{tabular}

Nota: RC RC - Propágulo coletado no Rio Cascalho e plantado no Rio Cascalho. RC IC - Propágulo coletado na Ilha do Cardoso e plantado no Rio Cascalho. 
Tabela 12. Parâmetros avaliados em propágulos e mudas no Canal da Cosipa

\begin{tabular}{|c|c|c|c|c|c|}
\hline \multicolumn{6}{|c|}{ Propágulos - mensurações antes do plantio - 07/02/03 } \\
\hline Código & $\begin{array}{l}\text { Massa } \\
\text { Úmida (g) }\end{array}$ & $\begin{array}{c}\text { Comprimento } \\
\text { Total }(\mathrm{cm})\end{array}$ & $\begin{array}{l}\text { Diâmetro do } \\
\text { centro (mm) }\end{array}$ & $\begin{array}{c}\text { Diâmetro da } \\
\text { base }(\mathrm{mm})\end{array}$ & $\begin{array}{l}\text { Diâmetro do } \\
\text { ápice }(\mathrm{mm})\end{array}$ \\
\hline CC CC 28 & 30 & 28,0 & 14,0 & 14,0 & 8,0 \\
\hline CC IC 24 & 50 & 32,0 & 11,0 & 12,0 & 8,0 \\
\hline CC IC 42 & 40 & 29,0 & 14,0 & 14,0 & 9,0 \\
\hline CC IC 43 & 50 & 36,0 & 11,5 & 12,5 & 8,0 \\
\hline \multicolumn{6}{|c|}{ Mudas - mensurações no momento da arrancamento - 16/03/04 } \\
\hline Código & $\begin{array}{l}\text { Altura planta } \\
\text { (cm) }\end{array}$ & $\begin{array}{c}\text { Diâmetro do } \\
\text { Colo (mm) }\end{array}$ & $\begin{array}{l}\mathrm{N}^{\circ} \text { de } \\
\text { Folhas }\end{array}$ & $\begin{array}{l}\mathrm{N}^{\circ} \text { de } \\
\text { Ramos }\end{array}$ & $\begin{array}{l}\text { Presença de } \\
\text { Enraizamento }\end{array}$ \\
\hline CC CC 28 & 43,5 & 18,0 & 19 & 4 & Sim \\
\hline CC IC 24 & 50,0 & 14,5 & 27 & 4 & Sim \\
\hline CC IC 42 & 58,5 & 21,5 & 59 & 6 & Sim \\
\hline CC IC 43 & 44,5 & 17,5 & 12 & 3 & Sim \\
\hline
\end{tabular}

Nota: CC CC- Propágulo coletado no Canal da Cosipa e plantado no Canal da Cosipa. CC IC - Propágulo coletado na Ilha do Cardoso e plantado no Canal da Cosipa.

Tabela 13 - Parâmetros avaliados em propágulos e mudas na Ilha do Cardoso

\begin{tabular}{|c|c|c|c|c|c|}
\hline \multicolumn{6}{|c|}{ Propágulos - mensurações antes do plantio - 01/04/02 } \\
\hline Código & $\begin{array}{l}\text { Massa } \\
\text { Úmida }(g)\end{array}$ & $\begin{array}{c}\text { Comprimento } \\
\text { Total }(\mathrm{cm})\end{array}$ & $\begin{array}{l}\text { Diâmetro do } \\
\text { centro (mm) }\end{array}$ & $\begin{array}{c}\text { Diâmetro da } \\
\text { base }(\mathrm{mm})\end{array}$ & $\begin{array}{l}\text { Diâmetro do } \\
\text { ápice (mm) }\end{array}$ \\
\hline IC IC 17 & 40 & 32,0 & 13,16 & 14,60 & 8,15 \\
\hline IC IC 22 & 50 & 40,5 & 12,20 & 14,44 & 8,48 \\
\hline IC IC 24 & 40 & 40,5 & 10,45 & 12,40 & 7,69 \\
\hline IC IC 25 & 40 & 37,5 & 11,21 & 13,25 & 8,09 \\
\hline IC IC 30 & 30 & 34,0 & 8,96 & 11,13 & 6,61 \\
\hline IC IC 35 & 50 & 45,0 & 12,68 & 13,29 & 8,18 \\
\hline IC IC 50 & 30 & 31,5 & 10,48 & 11,78 & 6,37 \\
\hline \multicolumn{6}{|c|}{ Mudas - mensurações no momento da arrancamento $-05 / 12 / 03$} \\
\hline Código & $\begin{array}{c}\text { Altura } \\
\text { planta (cm) }\end{array}$ & $\begin{array}{l}\text { Diâmetro do } \\
\text { Colo (mm) }\end{array}$ & $\begin{array}{l}\mathrm{N}^{\circ} \text { de } \\
\text { Folhas }\end{array}$ & $\begin{array}{l}\mathrm{N}^{\circ} \mathrm{de} \\
\text { Ramos }\end{array}$ & $\begin{array}{l}\text { Presença de } \\
\text { Enraizamento }\end{array}$ \\
\hline IC IC 17 & 58,0 & 14,5 & 4 & 0 & Sim \\
\hline IC IC 22 & 47,0 & 15,5 & 4 & 0 & Sim \\
\hline IC IC 24 & 56,0 & 13,5 & 6 & 0 & Sim \\
\hline IC IC 25 & 66,0 & 15,0 & 14 & 2 & Sim \\
\hline IC IC 30 & 57,0 & 19,0 & 8 & 0 & Sim \\
\hline IC IC 35 & 39,0 & 15,0 & 4 & 2 & Sim \\
\hline IC IC 50 & 45,0 & 19,5 & 8 & 0 & Sim \\
\hline
\end{tabular}

Nota : IC IC - Propágulo coletado na Ilha do Cardoso e plantado na llha do Cardoso. 
Da avaliação das Tabelas anteriores percebe-se que a quantidade final de mudas que se desenvolveram foi pequena, especialmente para o Rio Mariana (mortalidade 100\%) e também para o Canal da Cosipa, o que implica em uma avaliação que pode não ser representativa pelo pequeno número de repetições. No entanto, as tendências observadas dos dados obtidos demonstram claramente que não há correlação entre os parâmetros medidos no propágulo, não há correlação entre os parâmetros medidos na muda e não há correlação entre parâmetros medidos no propágulo e na muda.

Disto se conclui que o desenvolvimento da muda é virtualmente independente das características do propágulo, podendo a coleta destinada ao plantio ser feita com aproveitamento de qualquer tipo de propágulo em relação às dimensões, devendo ser observado apenas que não haja danos neste (provocados por predação, apodrecimento, prensamento, esfoliações, etc).

Esta informação contraria, em parte, CETESB (1989), que destaca que "o grau de viviparidade, a localização dos tecidos de flutuação, o tamanho e, sobretudo, o peso do propágulo são fatores que determinam as condições de dispersão, estabelecimento e a taxa de sobrevivência das plântulas" No que se refere ao estabelecimento e taxa de sobrevivência, os resultados do presente estudo indicaram que deve haver fatores extrínsecos ao propágulo que podem atuar como causas preponderantes à mortalidade. Davis (1940), cujas conclusões também diferiram deste estudo, coloca que há uma correlação entre a massa do propágulo e a taxa de mortalidade da espécie, sendo que a medida que a massa diminui, a mortalidade aumenta, especialmente para $R$. mangle.

A forma curva ou retilínea do propágulo não interfere na qualidade da muda plantada. Na regeneração natural, os propágulos curvos tem o autoplantio quando da queda, fisicamente mais difícil, porém enroscam-se facilmente nas raízes, desenvolvem raízes mesmo em posição horizontal e se fixam ao solo, dando origem a mudas que se endireitam verticalmente. Este fato indica que também não há restrição à coleta de propágulos curvos. 
Por fim, quanto à presença de raízes no propágulo, verificou-se ser fato comum, uma vez que enraízam facilmente no ambiente úmido mesmo sem estar em contato com o solo (este fato ocorreu também nos propágulos reservados para replantio, que desenvolveram não somente raízes mas folhas e ramos nos baldes de armazenamento). Para o plantio a presença de raízes em quantidade dificulta o enterramento e pode ser necessário uma poda de limpeza prévia, mas a presença prévia de raízes não garante o melhor desenvolvimento da muda.

\subsection{Secagem dos propágulos}

Para um lote de 20 propágulos / área foi feita a secagem visando avaliar a conversão MU:MS. Para estes foram também mensurados os parâmetros diâmetro e comprimento com a finalidade de estabelecer uma possível relação entre tais medidas e a massa. Os resultados obtidos são apresentados nas Tabelas 14 a 17. 
Tabela 14. Mensurações de propágulos e MU:MS para Canal da Cosipa

\begin{tabular}{|c|c|c|c|c|c|c|c|}
\hline No. & $\begin{array}{c}\text { Comprimento } \\
\text { total } \\
\text { (cm) }\end{array}$ & $\begin{array}{c}\text { Diâmetro } \\
\text { centro } \\
(\mathrm{mm})\end{array}$ & $\begin{array}{c}\text { Diâmetro } \\
\text { base } \\
(\mathrm{mm})\end{array}$ & $\begin{array}{c}\text { Diâmetro } \\
\text { ápice } \\
(\mathrm{mm})\end{array}$ & $\begin{array}{l}\text { MU } \\
\text { (g) }\end{array}$ & $\begin{array}{l}\text { MS } \\
\text { (g) }\end{array}$ & $\begin{array}{c}\text { Conversão } \\
\text { MU : MS } \\
\text { (\%) }\end{array}$ \\
\hline 1 & 29,00 & 10,27 & 12,89 & 6,57 & 20,00 & 8,20 & $41,00 \%$ \\
\hline 2 & 42,50 & 10,45 & 14,30 & 7,52 & 40,00 & 14,90 & $37,25 \%$ \\
\hline 3 & 37,00 & 10,38 & 15,82 & 7,84 & 20,00 & 16,20 & $81,00 \%$ \\
\hline 4 & 39,00 & 12,53 & 14,38 & 7,38 & 50,00 & 17,70 & $35,40 \%$ \\
\hline 5 & 31,00 & 11,87 & 12,27 & 7,19 & 30,00 & 11,20 & $37,33 \%$ \\
\hline 6 & 26,00 & 10,11 & 12,79 & 6,37 & 30,00 & 8,80 & $29,33 \%$ \\
\hline 7 & 46,50 & 11,60 & 14,49 & 7,02 & 20,00 & 19,70 & $98,50 \%$ \\
\hline 8 & 30,00 & 10,23 & 13,42 & 6,58 & 30,00 & 11,00 & $36,66 \%$ \\
\hline 9 & 28,00 & 11,87 & 13,82 & 6,83 & 30,00 & 12,40 & $41,33 \%$ \\
\hline 10 & 30,00 & 8,85 & 10,75 & 6,51 & 30,00 & 6,10 & $20,33 \%$ \\
\hline 11 & 34,00 & 10,54 & 13,22 & 7,03 & 20,00 & 9,00 & $45,00 \%$ \\
\hline 12 & 29,00 & 11,15 & 13,92 & 7,17 & 40,00 & 10,70 & $26,75 \%$ \\
\hline 13 & 29,00 & 10,82 & 13,24 & 6,43 & 20,00 & 11,10 & $55,55 \%$ \\
\hline 14 & 27,00 & 10,95 & 12,75 & 6,70 & 50,00 & 10,20 & $20,40 \%$ \\
\hline 15 & 32,00 & 11,66 & 14,42 & 7,53 & 30,00 & 16,00 & $53,33 \%$ \\
\hline 16 & 26,00 & 11,01 & 11,88 & 7,67 & 30,00 & 12,00 & $40,00 \%$ \\
\hline 17 & 43,00 & 11,25 & 14,26 & 7,60 & 20,00 & 19,10 & $95,50 \%$ \\
\hline 18 & 27,00 & 11,48 & 13,03 & 6,80 & 30,00 & 12,00 & $40,00 \%$ \\
\hline 19 & 30,00 & 11,33 & 13,50 & 7,48 & 40,00 & 11,30 & $28,25 \%$ \\
\hline 20 & 27,50 & 10,57 & 13,67 & 7,44 & 40,00 & 10,80 & $27,00 \%$ \\
\hline
\end{tabular}

$\mathrm{CC} \rightarrow(\mathrm{MU}: \mathrm{MS})$ média $=44,50 \%$. 
Tabela 15. Mensurações de propágulos e MU:MS para Rio Cascalho

\begin{tabular}{cccccccc}
\hline No. & $\begin{array}{c}\text { Comprimento } \\
\text { total } \\
\mathbf{( c m})\end{array}$ & $\begin{array}{c}\text { Diâmetro } \\
\text { centro } \\
\mathbf{( m m})\end{array}$ & $\begin{array}{c}\text { Diâmetro } \\
\text { base } \\
\mathbf{( m m})\end{array}$ & $\begin{array}{c}\text { Diâmetro } \\
\text { ápice } \\
\mathbf{( m m})\end{array}$ & $\begin{array}{c}\text { MU } \\
\mathbf{( g )}\end{array}$ & $\begin{array}{c}\text { MS } \\
\mathbf{( g )}\end{array}$ & $\begin{array}{c}\text { Conversão } \\
\text { MU : MS } \\
\mathbf{( \% )}\end{array}$ \\
\hline 1 & 38,00 & 11,62 & 13,34 & 7,10 & 40,00 & 7,10 & $17,50 \%$ \\
2 & 40,00 & 11,01 & 14,03 & 7,27 & 40,00 & 7,27 & $16,00 \%$ \\
3 & 42,00 & 7,87 & 10,03 & 6,41 & 30,00 & 6,41 & $10,70 \%$ \\
4 & 42,00 & 10,69 & 12,49 & 6,87 & 40,00 & 6,87 & $20,00 \%$ \\
5 & 26,00 & 6,42 & 8,08 & 5,24 & 20,00 & 5,24 & $3,20 \%$ \\
6 & 37,00 & 11,12 & 13,16 & 7,39 & 40,00 & 7,39 & $15,40 \%$ \\
7 & 44,00 & 10,54 & 11,97 & 6,68 & 40,00 & 6,68 & $15,60 \%$ \\
8 & 35,00 & 9,94 & 12,97 & 6,75 & 30,00 & 6,75 & $12,00 \%$ \\
9 & 30,00 & 8,98 & 11,01 & 6,73 & 40,00 & 6,73 & $7,50 \%$ \\
10 & 40,00 & 9,52 & 11,33 & 7,01 & 20,00 & 7,01 & $11,00 \%$ \\
11 & 33,00 & 12,39 & 13,17 & 8,01 & 40,00 & 14,70 & $36,75 \%$ \\
12 & 35,00 & 10,07 & 12,19 & 7,51 & 30,00 & 11,50 & $38,33 \%$ \\
13 & 42,50 & 11,75 & 14,03 & 7,51 & 40,00 & 22,50 & $56,25 \%$ \\
14 & 34,50 & 12,27 & 14,39 & 8,14 & 40,00 & 17,20 & $43,00 \%$ \\
15 & 42,00 & 10,65 & 12,32 & 7,35 & 40,00 & 17,00 & $42,50 \%$ \\
16 & 39,50 & 11,81 & 14,27 & 7,35 & 40,00 & 17,70 & $44,25 \%$ \\
17 & 36,00 & 12,42 & 13,42 & 8,42 & 40,00 & 19,30 & $48,25 \%$ \\
18 & 29,00 & 12,44 & 14,86 & 7,31 & 30,00 & 15,10 & $50,33 \%$ \\
19 & 37,00 & 11,01 & 12,57 & 7,24 & 30,00 & 15,70 & $52,33 \%$ \\
20 & 36,00 & 10,19 & 13,22 & 6,91 & 30,00 & 16,00 & $53,33 \%$ \\
\hline
\end{tabular}

$\mathrm{RC} \rightarrow(\mathrm{MU}: \mathrm{MS})$ média $=29,71 \%$. 
Tabela 16. Mensurações de propágulos e MU:MS para Rio Mariana

\begin{tabular}{cccccccc}
\hline No. & $\begin{array}{c}\text { Comprimento } \\
\text { total } \\
\mathbf{( c m})\end{array}$ & $\begin{array}{c}\text { Diâmetro } \\
\text { centro } \\
\mathbf{( m m})\end{array}$ & $\begin{array}{c}\text { Diâmetro } \\
\text { base } \\
\mathbf{( m m})\end{array}$ & $\begin{array}{c}\text { Diâmetro } \\
\text { ápice } \\
\mathbf{( m m})\end{array}$ & $\begin{array}{c}\text { MU } \\
\mathbf{( g )}\end{array}$ & $\begin{array}{c}\text { MS } \\
\mathbf{( g )}\end{array}$ & $\begin{array}{c}\text { Conversão } \\
\text { MU : MS } \\
\mathbf{( \% )}\end{array}$ \\
\hline 1 & 25,50 & 8,05 & 10,38 & 6,93 & 20,00 & 6,60 & $33,00 \%$ \\
2 & 42,00 & 10,55 & 12,77 & 7,36 & 40,00 & 16,50 & $41,25 \%$ \\
3 & 30,00 & 12,27 & 13,16 & 8,37 & 30,00 & 11,70 & $39,00 \%$ \\
4 & 29,50 & 8,58 & 10,97 & 5,93 & 20,00 & 7,30 & $51,00 \%$ \\
5 & 39,00 & 10,71 & 12,31 & 6,88 & 30,00 & 15,30 & $48,00 \%$ \\
6 & 35,00 & 8,79 & 11,73 & 6,10 & 20,00 & 9,60 & $58,00 \%$ \\
7 & 36,50 & 11,70 & 14,05 & 6,78 & 30,00 & 17,40 & $58,50 \%$ \\
8 & 30,50 & 11,62 & 12,93 & 7,30 & 20,00 & 11,70 & $47,50 \%$ \\
9 & 30,00 & 9,95 & 12,71 & 7,26 & 20,00 & 9,50 & $27,00 \%$ \\
10 & 23,00 & 9,38 & 10,48 & 6,39 & 20,00 & 5,40 & $47,66 \%$ \\
11 & 38,50 & 11,09 & 13,68 & 6,93 & 30,00 & 14,30 & $47,66 \%$ \\
12 & 39,50 & 11,46 & 14,25 & 7,14 & 40,00 & 18,10 & $45,25 \%$ \\
13 & 28,00 & 11,23 & 13,29 & 7,24 & 20,00 & 12,00 & $60,00 \%$ \\
14 & 45,50 & 10,10 & 12,07 & 7,07 & 30,00 & 15,40 & $51,33 \%$ \\
15 & 28,00 & 11,35 & 12,07 & 6,99 & 20,00 & 9,50 & $47,50 \%$ \\
16 & 41,00 & 11,75 & 14,23 & 7,92 & 40,00 & 19,00 & $47,50 \%$ \\
17 & 36,00 & 9,19 & 11,01 & 7,43 & 40,00 & 10,00 & $25,00 \%$ \\
18 & 39,50 & 10,55 & 11,01 & 7,33 & 20,00 & 16,50 & $82,50 \%$ \\
19 & 35,50 & 14,71 & 14,03 & 6,97 & 40,00 & 17,70 & $44,25 \%$ \\
20 & 30,50 & 10,42 & 13,07 & 7,37 & 30,00 & 10,00 & $33,33 \%$ \\
\hline
\end{tabular}

$\mathrm{RM} \rightarrow(\mathrm{MU}: \mathrm{MS})$ média $=46,76 \%$. 
Tabela 17. Mensurações de propágulos e MU:MS para Ilha do Cardoso

\begin{tabular}{cccccccc}
\hline No. & $\begin{array}{c}\text { Comprimento } \\
\text { total } \\
(\mathbf{c m})\end{array}$ & $\begin{array}{c}\text { Diâmetro } \\
\text { centro } \\
\mathbf{( m m}\end{array}$ & $\begin{array}{c}\text { Diâmetro } \\
\text { base } \\
\mathbf{( m m})\end{array}$ & $\begin{array}{c}\text { Diâmetro } \\
\text { ápice } \\
\mathbf{( m m})\end{array}$ & $\begin{array}{c}\text { MU } \\
\mathbf{( g )}\end{array}$ & $\begin{array}{c}\text { MS } \\
\mathbf{( g )}\end{array}$ & $\begin{array}{c}\text { Conversão } \\
\text { MU : MS } \\
\mathbf{( \% )}\end{array}$ \\
\hline 1 & 33,00 & 12,39 & 13,17 & 8,01 & 40,00 & 14,70 & $36,75 \%$ \\
2 & 35,00 & 10,07 & 12,19 & 7,51 & 30,00 & 11,50 & $38,33 \%$ \\
3 & 42,50 & 11,75 & 14,03 & 7,51 & 40,00 & 22,50 & $56,25 \%$ \\
4 & 34,50 & 12,27 & 12,32 & 8,14 & 40,00 & 17,20 & $43,00 \%$ \\
5 & 42,00 & 10,65 & 14,27 & 7,35 & 40,00 & 17,00 & $42,50 \%$ \\
6 & 39,50 & 11,81 & 13,42 & 7,35 & 40,00 & 17,70 & $44,25 \%$ \\
7 & 36,00 & 12,42 & 14,86 & 8,42 & 40,00 & 19,30 & $48,25 \%$ \\
8 & 29,00 & 12,44 & 12,57 & 7,31 & 30,00 & 15,10 & $50,33 \%$ \\
9 & 37,00 & 11,01 & 13,22 & 7,24 & 30,00 & 15,70 & $52,33 \%$ \\
10 & 36,00 & 10,19 & 12,00 & 6,91 & 30,00 & 16,00 & $53,33 \%$ \\
11 & 35,00 & 10,99 & 12,00 & 7,24 & 30,00 & 13,60 & $45,33 \%$ \\
12 & 31,50 & 10,89 & 13,47 & 6,95 & 30,00 & 13,40 & $44,66 \%$ \\
13 & 30,50 & 9,87 & 11,69 & 6,47 & 20,00 & 9,80 & $49,00 \%$ \\
14 & 43,00 & 11,74 & 14,41 & 7,49 & 40,00 & 22,80 & $57,00 \%$ \\
15 & 39,00 & 10,60 & 13,56 & 7,10 & 30,00 & 17,50 & $58,33 \%$ \\
16 & 36,50 & 12,11 & 12,28 & 7,44 & 30,00 & 16,20 & $54,00 \%$ \\
17 & 35,00 & 12,36 & 14,65 & 7,28 & 30,00 & 16,20 & $54,00 \%$ \\
18 & 37,50 & 11,16 & 13,56 & 7,54 & 30,00 & 18,00 & $60,00 \%$ \\
19 & 28,00 & 11,11 & 13,31 & 7,43 & 20,00 & 11,00 & $55,00 \%$ \\
20 & 37,00 & 9,63 & 11,71 & 7,54 & 20,00 & 12,60 & $60,00 \%$ \\
\hline & & & & & & & \\
\hline
\end{tabular}

IC $\rightarrow(\mathrm{MU}: \mathrm{MS})$ média = 50,13\%. 
Dos resultados obtidos corrobora-se a discussão apresentada no item anterior (Características do propágulo e desenvolvimento da muda), onde foi afirmado que não há uma relação entre os parâmetros avaliados no propágulo. Verifica-se adicionalmente que não há também uma relação entre estes parâmetros e as massas (MU e MS), o que implica em uma conversão de MU:MS não relacionada às dimensões do propágulo.

É bem evidente também a grande variação nas taxas de conversão de massa de forma que a perda de água é extremamente variável e a massa final (MS) não se relaciona com a massa no início da secagem (MU). Assim, a taxa média de conversão média para as áreas foi calculada, porém o emprego desta seria questionável, o que justifica o fato de não terem sido realizadas análises adicionais neste trabalho empregando o parâmetro MS além do MU.

Assim, foi feita uma comparação ilustrativa da taxa média de conversão obtida para as áreas: IC $(50,13 \%)>$ RM $(46,76 \%)>$ CC $(44,50 \%)>$ RC (29,71\%), de onde se verifica uma tendência de maior perda de água em propágulos originados de áreas com bosque de Manguezal mais desenvolvido (Ilha do Cardoso e Rio Mariana) ou mais conservados (Ilha do Cardoso).

\section{4 Árvores matriz}

\section{Projeção da copa}

Com os dados mensurados em campo foi elaborado o croqui da projeção de copa de cada uma das duas matrizes/área, conforme apresentado nas Figuras 50 a 52 a seguir. 
MATRIZ: M1

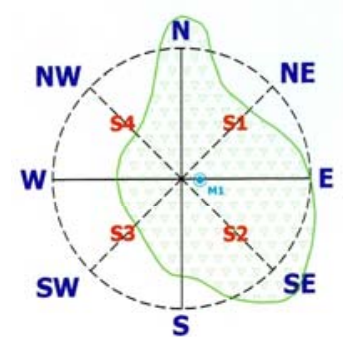

S1 setores Da matrazz

- porto de nseachio do tronco da dervor
MATRIZ: M2

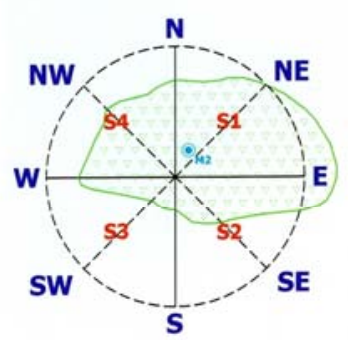

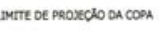

Figura 50 - Parcelas e projeção da copa das matrizes do Canal da Cosipa

MATRIZ: M1

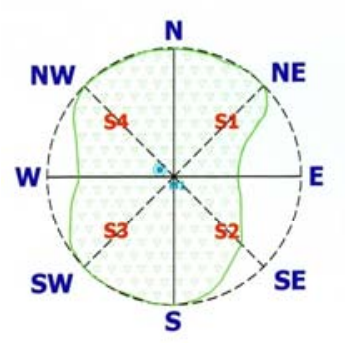

S1 stont

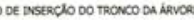

UMTEE DE PEOEECHO DA COSA
MATRIZ: M2

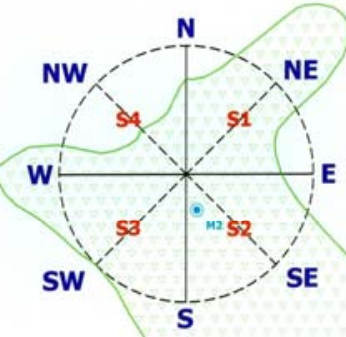

Figura 51 - Parcelas e projeção de copa das matrizes do Rio Cascalho

MATRIZ: M1

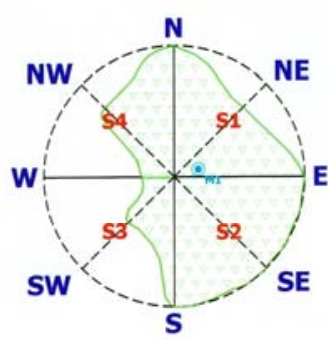

S1 STTORES OAMATRz

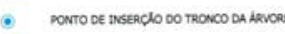

LYMTE DE PROSECSO DA COEA
MATRIZ: M2

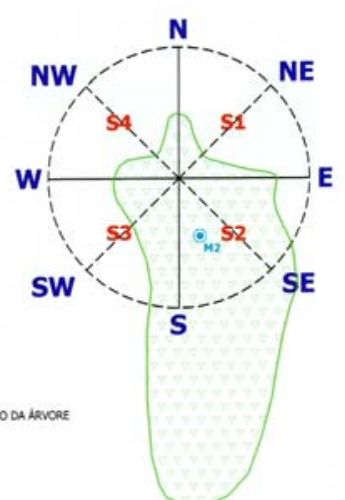

Figura 52 - Parcelas e projeção de copa das árvores matrizes do Rio Mariana 
De maneira geral, as copas das árvores de $R$. mangle são caracteristicamente bastante irregulares e muitas vezes deslocadas em relação ao tronco principal. A maior projeção de copa é na média encontrada nas matrizes do Rio Cascalho, seguida do Rio Mariana e por fim o Canal da Cosipa.

As figuras ilustram também, pela sua condição de matriz, que as árvores de uma mesma área em período de reprodução apresentam grande variação na forma da copa, o que pode vir a influenciar a quantidade de propágulos a serem produzidos, a distância de dispersão destes sob a projeção da matriz e a incidência luminosa no solo, o que por sua vez pode interferir sobre o desenvolvimento das mudas.

\section{Parâmetros da copa}

Além das variações na projeção da copa foram também analisados, estatisticamente, outros parâmetros da copa relacionados às ramificações e folhas, comparando-se as áreas de amostragem entre si.

Ressalta-se que tais parâmetros foram mensurados nos galhos coletados das matrizes quando da coleta de ramos / folhas para realização das análises químicas de concentração de metais nas folhas, ou seja, referem-se ao terço final do comprimento de galhos viçosos retirados da porção mediana da altura da copa (altura média de $4,30 \mathrm{~m}$ do solo). Os resultados estão apresentados na Tabela 18.

Tais resultados possibilitam uma comparação estatística entre as áreas para quantidade de ramos e folhas ilustrando a avaliação visual realizada com o desenho da projeção de copa. Deve ser ressaltado que nos croquis de projeção de copa só foram desenhadas as árvores matrizes e suas respectivas copas, no entanto árvores adjacentes também projetam suas copas para o interior da parcela. 
Tabela 18. Avaliação de parâmetros da copa (ramos e folhas) de R. mangle

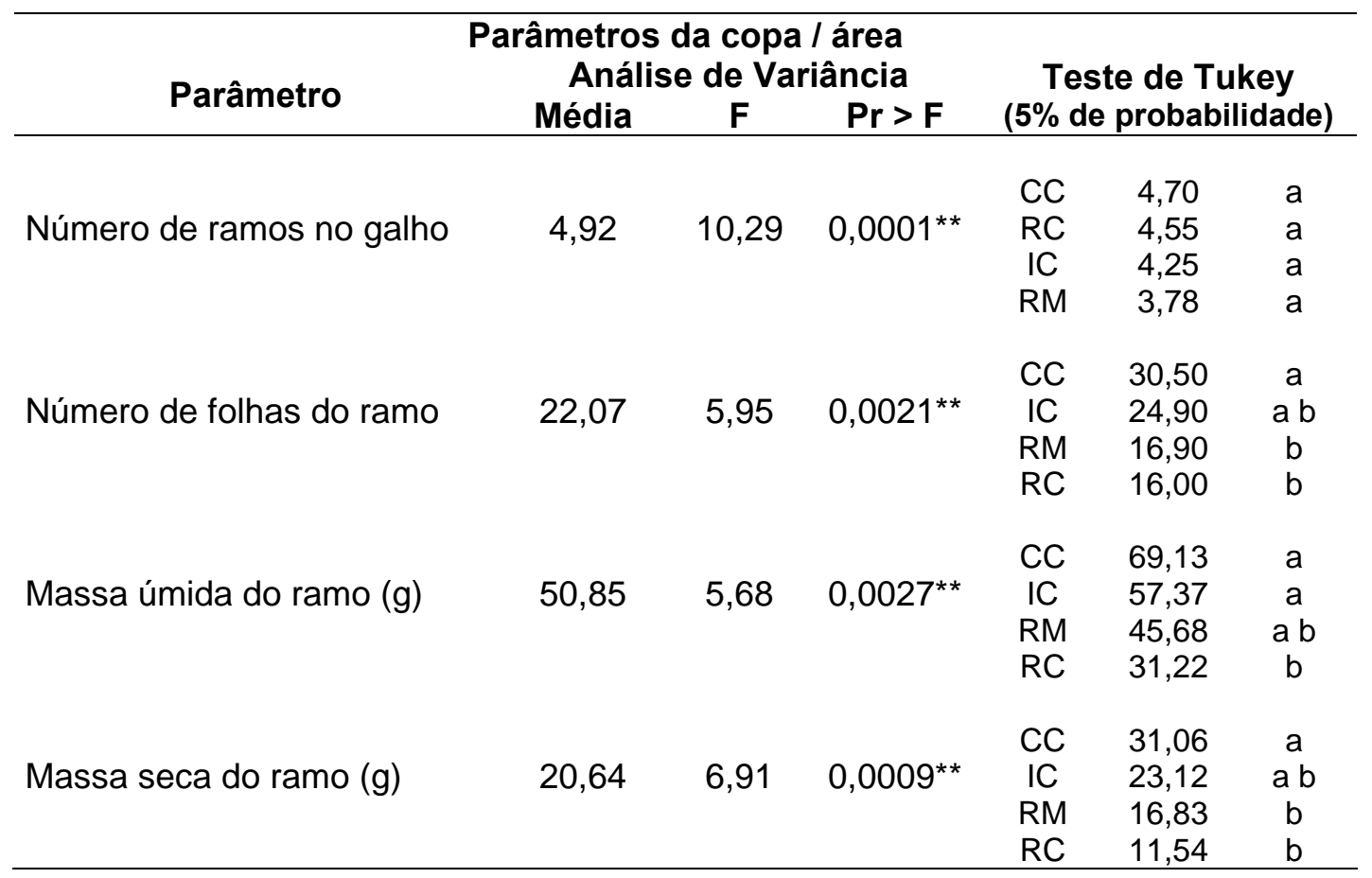

Legenda: Teste de Tukey para comparação de médias entre Áreas:

IC - Ilha do Cardoso; CC - Canal da Cosipa; RM - Rio Marina; RC - Rio Cascalho.

Os resultados indicam que para os quatro parâmetros avaliados há uma diferença altamente significativa entre as áreas, com as maiores médias no Canal da Cosipa, Ilha do Cardoso, Rio Mariana e por fim no Rio Cascalho.

Os dados de número de ramos e folhas/ramo não apresentaram relação direta com os resultados obtidos para projeção de copa (RC > RM > CC, vide item anterior), de forma que se conclui que no Canal da Cosipa as copas se projetam mais timidamente, porém apresentam uma compensação devido ao maior número de ramos/galho e maior número de folhas/galho, além de maior massa úmida e seca para o galho. 
Para o Rio Cascalho, há um raciocínio inverso pois as copas apresentam maior projeção, porém são menos densas e mais leves. Já o Rio Mariana, em ambos os casos (projeção de copa e características dos ramos e folhas) foi mantida a situação intermediária entre as áreas.

Para a Ilha do Cardoso, com a segunda melhor posição em relação aos parâmetros dos ramos e folhas, a comparação não é possível pois não foram implantadas parcelas matriz e, portanto, não há dados de projeção de copa.

Estabelecimento de indivíduos jovens sob a árvore matriz

As parcelas de árvores matriz possibilitaram a obtenção de dados sobre a própria matriz e também a coleta de dados sobre a regeneração, pela avaliação de propágulos e indivíduos jovens sob a copa. Os resultados obtidos nesta avaliação são apresentados nas Tabelas 19 e 20 a seguir. 
Tabela 19. Avaliação de propágulos e mudas de $R$. mangle e de outras espécies (A. shaueriana) sob as matrizes, em classes de altura

\begin{tabular}{|c|c|c|c|c|c|c|}
\hline \multirow{3}{*}{$\begin{array}{l}\text { Parâmetro } \\
\text { Mudas de R. mangle } \\
\text { até } 20 \mathrm{~cm}\end{array}$} & \multicolumn{3}{|c|}{$\begin{array}{l}\text { Jovens / área } \\
\text { Análise de Variância }\end{array}$} & \multirow{2}{*}{\multicolumn{3}{|c|}{$\begin{array}{l}\text { Teste de Tukey } \\
\text { ( } 5 \% \text { de probabilidade) }\end{array}$}} \\
\hline & Média & $\mathbf{F}$ & $\operatorname{Pr}>\mathrm{F}$ & & & \\
\hline & 0,82 & 6,64 & 0,0020 ** & $\begin{array}{l}\mathrm{RC} \\
\mathrm{CC} \\
\mathrm{RM}\end{array}$ & $\begin{array}{l}1,04 \\
0,71 \\
0,71\end{array}$ & $\begin{array}{l}\mathrm{a} \\
\mathrm{b} \\
\mathrm{b}\end{array}$ \\
\hline $\begin{array}{l}\text { Mudas de } R \text {. mangle } \\
\text { de } 20,1-40 \mathrm{~cm}\end{array}$ & 0,74 & 1,60 & $0,2078 \mathrm{~ns}$ & $\begin{array}{l}\mathrm{RM} \\
\mathrm{RC} \\
\mathrm{CC}\end{array}$ & $\begin{array}{l}0,75 \\
0,75 \\
0,71\end{array}$ & $\begin{array}{l}\mathrm{a} \\
\mathrm{a} \\
\mathrm{a}\end{array}$ \\
\hline $\begin{array}{l}\text { Mudas de } R \text {. mangle } \\
\text { de } 40,1-60 \mathrm{~cm}\end{array}$ & 0,92 & 2,29 & $0,1072 \mathrm{~ns}$ & $\begin{array}{l}\mathrm{CC} \\
\mathrm{RC} \\
\mathrm{RM}\end{array}$ & $\begin{array}{l}1,00 \\
0,90 \\
0,84\end{array}$ & $\begin{array}{l}\mathrm{a} \\
\mathrm{a} \\
\mathrm{a}\end{array}$ \\
\hline $\begin{array}{l}\text { Mudas de } R \text {. mangle } \\
\text { de } 60,1-80 \mathrm{~cm}\end{array}$ & 1,03 & 10,92 & 0,0001 ** & $\begin{array}{l}\mathrm{RC} \\
\mathrm{RM} \\
\mathrm{CC}\end{array}$ & $\begin{array}{l}1,38 \\
0,91 \\
0,80\end{array}$ & $\begin{array}{l}a \\
b \\
b\end{array}$ \\
\hline $\begin{array}{l}\text { Mudas de R. mangle } \\
>80 \mathrm{~cm}\end{array}$ & 1,08 & 2,95 & $0,0573 \mathrm{~ns}$ & $\begin{array}{l}\mathrm{RM} \\
\mathrm{RC} \\
\mathrm{CC}\end{array}$ & $\begin{array}{l}1,24 \\
1,06 \\
0,94\end{array}$ & $\begin{array}{c}a \\
a b \\
b\end{array}$ \\
\hline $\begin{array}{l}\text { Propágulos de } \\
\text { R. mangle enraizados }\end{array}$ & 0,83 & 7,57 & 0,0009 ** & $\begin{array}{l}\mathrm{RM} \\
\mathrm{RC} \\
\mathrm{CC}\end{array}$ & $\begin{array}{l}0,97 \\
0,80 \\
0,71\end{array}$ & $\begin{array}{l}a \\
b \\
b\end{array}$ \\
\hline $\begin{array}{l}\text { Propágulos de } \\
\text { R. mangle superficiais }\end{array}$ & 1,08 & 42,11 & 0,0001 ** & $\begin{array}{l}\mathrm{RM} \\
\mathrm{RC} \\
\mathrm{CC}\end{array}$ & $\begin{array}{l}1,71 \\
0,77 \\
0,77\end{array}$ & $\begin{array}{l}a \\
b \\
b\end{array}$ \\
\hline $\begin{array}{l}\text { Mudas de } A \text {. shaueriana } \\
\text { até } 80 \mathrm{~cm}\end{array}$ & 1,33 & 5,11 & 0,0079 ** & $\begin{array}{l}\mathrm{RM} \\
\mathrm{RC} \\
\mathrm{CC}\end{array}$ & $\begin{array}{l}1,54 \\
1,47 \\
0,98\end{array}$ & $\begin{array}{l}\mathrm{a} \\
\mathrm{a} \\
\mathrm{b}\end{array}$ \\
\hline $\begin{array}{l}\text { Mudas de } A . \text { shaueriana } \\
\text { espécies }>80 \mathrm{~cm}\end{array}$ & 1,07 & 3,54 & 0,0330 * & $\begin{array}{l}\mathrm{RC} \\
\mathrm{CC} \\
\mathrm{RM}\end{array}$ & $\begin{array}{l}1,30 \\
1,14 \\
0,75\end{array}$ & $\begin{array}{c}a \\
a b \\
b\end{array}$ \\
\hline $\begin{array}{l}\text { Propágulos de } A \text {. shaueriana } \\
\text { enraizados }\end{array}$ & 0,88 & 1,49 & $0,2311 \mathrm{~ns}$ & $\begin{array}{l}\mathrm{RC} \\
\mathrm{RM} \\
\mathrm{CC}\end{array}$ & $\begin{array}{l}0,99 \\
0,85 \\
0,80\end{array}$ & $\begin{array}{l}\mathrm{a} \\
\mathrm{a} \\
\mathrm{a}\end{array}$ \\
\hline $\begin{array}{l}\text { Propágulos de } A \text {. shaueriana } \\
\text { superficiais }\end{array}$ & 0,81 & 0,33 & $0,7187 \mathrm{~ns}$ & $\begin{array}{l}\mathrm{CC} \\
\mathrm{RM} \\
\mathrm{CC}\end{array}$ & $\begin{array}{l}0,83 \\
0,81 \\
0,78\end{array}$ & $\begin{array}{l}\mathrm{a} \\
\mathrm{a} \\
\mathrm{a}\end{array}$ \\
\hline
\end{tabular}

Legenda: Teste de Tukey para comparação de médias entre Áreas:

CC - Canal da Cosipa; RM - Rio Marina; RC - Rio Cascalho. 
Tabela 20. Avaliação de propágulos e mudas de $R$. mangle e outras espécies (A. shaueriana) sob as matrizes, comparando as matrizes entre si

\begin{tabular}{|c|c|c|c|c|c|c|}
\hline \multirow{2}{*}{$\begin{array}{l}\text { Parâmetro } \\
\text { Mudas de R. mangle } \\
\text { até } 20 \mathrm{~cm}\end{array}$} & \multicolumn{3}{|c|}{$\begin{array}{l}\text { ovens / área / matriz } \\
\text { Análise de Variância }\end{array}$} & \multicolumn{3}{|c|}{$\begin{array}{l}\text { Teste de Tukey } \\
\text { (5\% de probabilidade) }\end{array}$} \\
\hline & 0,82 & 0,29 & $0,5909 \mathrm{~ns}$ & $\begin{array}{l}\text { M1 } \\
\text { M2 }\end{array}$ & $\begin{array}{l}0,48 \\
0,27\end{array}$ & $\begin{array}{l}\mathrm{a} \\
\mathrm{a}\end{array}$ \\
\hline $\begin{array}{l}\text { Mudas de } R \text {. mangle } \\
\text { de } 20,1-40 \mathrm{~cm}\end{array}$ & 0,74 & 0,71 & $0,4015 \mathrm{~ns}$ & $\begin{array}{l}\text { M2 } \\
\text { M1 }\end{array}$ & $\begin{array}{l}0,08 \\
0,04\end{array}$ & $\begin{array}{l}\mathrm{a} \\
\mathrm{a}\end{array}$ \\
\hline $\begin{array}{l}\text { Mudas de } R \text {. mangle } \\
\text { de } 40,1-60 \mathrm{~cm}\end{array}$ & 0,92 & 4,28 & 0,0414 * & $\begin{array}{l}\text { M2 } \\
\text { M1 }\end{array}$ & $\begin{array}{l}0,60 \\
0,29\end{array}$ & $\begin{array}{l}\mathrm{a} \\
\mathrm{b}\end{array}$ \\
\hline $\begin{array}{l}\text { Mudas de } R \text {. mangle } \\
\text { de } 60,1-80 \mathrm{~cm}\end{array}$ & 1,03 & 3,43 & $0,0673 \mathrm{~ns}$ & $\begin{array}{l}\text { M1 } \\
\text { M2 }\end{array}$ & $\begin{array}{l}1,33 \\
0,48\end{array}$ & $\begin{array}{l}\mathrm{a} \\
\mathrm{a}\end{array}$ \\
\hline $\begin{array}{l}\text { Mudas de R. mangle } \\
>80 \mathrm{~cm}\end{array}$ & 1,08 & 5,41 & 0,0222 * & $\begin{array}{l}\text { M1 } \\
\text { M2 }\end{array}$ & $\begin{array}{l}1,29 \\
0,54\end{array}$ & $\begin{array}{l}\mathrm{a} \\
\mathrm{b}\end{array}$ \\
\hline $\begin{array}{l}\text { Propágulos de } R \text {. mangle } \\
\text { enraizados }\end{array}$ & 0,83 & 0,00 & $0,9869 \mathrm{~ns}$ & $\begin{array}{l}\text { M1 } \\
\text { M2 }\end{array}$ & $\begin{array}{l}0,29 \\
0,25\end{array}$ & $\begin{array}{l}\mathrm{a} \\
\mathrm{a}\end{array}$ \\
\hline $\begin{array}{l}\text { Propágulos de } R \text {. mangle } \\
\text { superficiais }\end{array}$ & 1,08 & 0,67 & $0,4147 \mathrm{~ns}$ & $\begin{array}{l}\text { M1 } \\
\text { M2 }\end{array}$ & $\begin{array}{l}1,29 \\
0,89\end{array}$ & $\begin{array}{l}\mathrm{a} \\
\mathrm{a}\end{array}$ \\
\hline $\begin{array}{l}\text { Mudas de } A \text {. shaueriana até } \\
80 \mathrm{~cm}\end{array}$ & 1,33 & 6,24 & 0,0143 * & $\begin{array}{l}\text { M1 } \\
\text { M2 }\end{array}$ & $\begin{array}{l}2,66 \\
1,20\end{array}$ & $\begin{array}{l}\mathrm{a} \\
\mathrm{b}\end{array}$ \\
\hline $\begin{array}{l}\text { Mudas de } A . \text { shaueriana } \\
>80 \mathrm{~cm}\end{array}$ & 1,07 & 6,87 & 0,0103 * & $\begin{array}{l}\text { M1 } \\
\text { M2 }\end{array}$ & $\begin{array}{l}2,54 \\
0,31\end{array}$ & $\begin{array}{l}a \\
b\end{array}$ \\
\hline $\begin{array}{l}\text { Propágulos de } A \text {. shaueriana } \\
\text { enraizados }\end{array}$ & 0,88 & 0,01 & $0,9238 \mathrm{~ns}$ & $\begin{array}{l}\text { M1 } \\
\text { M2 }\end{array}$ & $\begin{array}{l}0,50 \\
0,43\end{array}$ & $\begin{array}{l}\mathrm{a} \\
\mathrm{a}\end{array}$ \\
\hline $\begin{array}{l}\text { Propágulos de } A . \text { shaueri } \\
\text { superficiais }\end{array}$ & 0,80 & 0,19 & $0,6656 \mathrm{~ns}$ & $\begin{array}{l}\text { M2 } \\
\text { M1 }\end{array}$ & $\begin{array}{l}0,25 \\
0,19\end{array}$ & $\begin{array}{l}\mathrm{a} \\
\mathrm{a}\end{array}$ \\
\hline
\end{tabular}

Legenda: Teste de Tukey para comparação de médias entre Matrizes: M1 - Matriz 1; M2 - Matriz 2

Da Tabela 19 depreende-se que a quantidade de propágulos (enraizados e superficiais) de $A$. shaueriana sob as matrizes não apresentou diferenças entre as áreas avaliadas, porém quanto aos propágulos (enraizados e superficiais) de $R$. mangle, houve uma diferença altamente significativa, com o Rio Mariana apresentando as maiores médias. 
Não se verificou diferenças para a quantificação de mudas de $R$. mangle com altura de 20,1 a $40 \mathrm{~cm}$, de 40,1 a $60 \mathrm{~cm}$ e $>80 \mathrm{~cm}$, que foram estatisticamente semelhantes nas três áreas. Por outro lado, para as mudas até $20 \mathrm{~cm}$ e de 60,1 a $80 \mathrm{~cm}$ a variação entre áreas foi altamente significativa; no primeiro caso a maior quantidade de mudas foi encontrada no Rio Cascalho, seguido do Canal da Cosipa e Rio Mariana, o que ocorre de forma semelhante no segundo caso, a maior quantidade de mudas de altura entre 60,1 a $80 \mathrm{~cm}$ no Rio Cascalho, seguida do Rio Mariana e Canal da Cosipa.

Para os intervalos de classes considerados, nota-se que há uma alternância entre as áreas, com maior média, entre o Rio Cascalho e Rio Mariana, não existindo tendência definida em relação a produção de mudas.

A quantidade de mudas no geral é baixa. Mudas pequenas (até $60 \mathrm{~cm}$ ) apresentam médias inferiores a 1 e mudas maiores (acima de 60cm) aparecem em quantidade um pouco maior, mas a média fica, ainda, apenas pouco superior a 1 muda sob a matrizlárea. Assim, conclui-se que mesmo havendo propágulos disponíveis na árvore matriz e dispersão via flutuação, não há uma conseqüente deposição e/ou fixação destes imediatamente abaixo da matriz.

A mesma avaliação se aplica à $A$. shaueriana, cuja diferença entre áreas foi altamente significativa para mudas até $80 \mathrm{~cm}$ e significativa a $5 \%$ para mudas acima de $80 \mathrm{~cm}$, mas as áreas também se alternam e a quantidade média é muito pouco superior à de $R$. mangle. Os resultados levam à conclusão que a regeneração sob as matrizes, para ambas as espécies, é muito pequena nas três áreas, sendo que o recrutamento encontra-se desequilibrado, uma vez que não se verificou maior número de plantas na primeira classe de tamanho.

A Tabela 20 possibilita a comparação das matrizes, considerando conjuntamente as três áreas avaliadas. Verifica-se desta que as duas espécies não apresentam diferença significativa em relação à quantidade média de propágulos sob as matrizes. Isto ocorreu também em relação às mudas das classes de altura até $20 \mathrm{~cm}$, de 20,1 a 40cm e de 60,1 à $80 \mathrm{~cm}$ de $R$. mangle. 
A diferença de quantidade de mudas de 40,1 a $60 \mathrm{~cm}$ é maior que $80 \mathrm{~cm}$ foi significativa a $5 \%$ de probabilidade para $R$. mangle, com a Matriz 2 apresentando média bastante superior à Matriz 1. No caso da $A$. shaueriana, para as duas classes de altura (maior e menor que $80 \mathrm{~cm}$ ) as matrizes apresentam médias que diferem significativamente a $5 \%$ de probabilidade, sendo a Matriz 1 sempre superior à Matriz 2.

Os resultados sugerem que há uma variação considerável na regeneração sob matrizes e que a quantidade de propágulos e mudas é de forma geral pequena.

\subsection{Inventário florestal}

Nas parcelas de inventário foi possível a coleta de dados para caracterização do bosque (avaliação dos indivíduos adultos) e caracterização da regeneração, (avaliação de propágulos e indivíduos jovens). Os resultados obtidos que permitem tal caracterização são apresentados nos itens a seguir.

\section{Caracterização do bosque - Perfil horizontal}

Para caracterizar o bosque foi feito, para cada área da Baixada Santista, o perfil horizontal que ilustra a situação da cobertura vegetal e possibilita a comparação entre as áreas avaliadas.

Estes perfis foram elaborados tomando como base a parcela de inventário subdividida em setores que funcionaram como referência espacial (eixo x) e as medições de altura das árvores e copas, coletadas no inventário, foram orientadoras do desenho no eixo y.

Os referidos perfis são apresentados na Figura 53 da seqüência. 
Figura 53 - Perfil horizontal do bosque das áreas amostradas na Baixada Santista. 
O bosque de Manguezal do Rio Mariana é muito mais denso com uma colonização muito mais intensa e com indivíduos arbóreos de maior porte. Há também uma intensidade de colonização no sub-bosque bem superior do que as demais áreas, aparecendo a gramínea Spartina brasiliensis (Spartina) ocupando trechos descontínuos e irregulares mas extensos, alguns exemplares de Acrosticum aureum (Samambaia do brejo) e árvores de $R$. mangle e de $A$. shaueriana (a R. mangle é bem mais abundante nesta faixa do Manguezal amostrado pela parcela do que a $A$. shaueriana, como seria esperado na franja do Manguezal). No estrato médio são freqüentes bromélias que aparecem desde a altura das raízes até a forquilha dos galhos da copa, apresentando duas ou três espécies predominantes; as orquídeas são raras.

Na situação do Rio Cascalho, o bosque é comparativamente menos denso e mais baixo. O solo apresenta-se aparente na maior parte da área, não havendo a presença de $S$. brasiliensis e raramente aparece a samambaia $A$. aureum. Também são bastante raras as bromélias e especialmente as orquídeas. Nas proximidades do bosque há uma clareira ocupada pelo agressivo Hibiscus tiliaceus (Algodão da praia), de forma que são vistos alguns indivíduos jovens desta planta na parcela. Na faixa da franja do Manguezal, onde está localizada a parcela, houve uma inversão de espécies, sendo bem mais freqüente $A$. shaueriana do que a $R$. mangle e nota-se que a distribuição dos indivíduos arbóreos dá-se em pequenas reboleiras entremeadas por indivíduos mais jovens.

Para o Canal da Cosipa a densidade é a mais baixa, porém o porte se assemelha ao do Rio Cascalho. O solo, mais firme e arenoso (os dois anteriores são muito mais argilosos), apresenta-se praticamente aparente em todo sub-bosque, uma vez que não está presente a $S$. brasiliensis e os indivíduos da samambaia $A$. aureum, que aparecem sozinhos ou em pequenos grupos, não chegam a recobrir completamente o solo. Aparecem algumas poucas bromélias especialmente de uma única espécie e orquídeas não foram 
observadas. Há um relativo equilíbrio entre a quantidade de exemplares de $R$. mangle e $A$. shaueriana e estas se distribuem de forma mais concentrada em alguns pontos e isoladas em outros, porém não de forma suficientemente maciça para possibilitar o fechamento do dossel, aparecendo pequenas clareiras. O bosque nesta área apresenta-se descontínuo, sendo uma faixa estreita acompanhando o canal e aos fundos há uma clareira que se estende formando uma grande mancha. Na área de contato com o canal, onde a ação das marolas é mais intensa, podem ser vistas várias árvores derrubadas, com as raízes expostas, que acabam por formar barreiras (não muito densas) que minimizam o impacto das marolas.

Os perfis apresentados ilustram a situação descrita, corroborando a suposição inicial de que as três áreas selecionadas para amostragem apresentam bosque em situação diferenciada quanto ao nível de interferência e diversidade de agentes tensores, sendo o Manguezal do Canal da Cosipa o mais degradado, o do Rio Mariana o mais conservado e o do Rio Cascalho ocuparia uma situação intermediária.

\section{$\underline{\text { Caracterização do bosque - projeção de copa nas parcelas de inventário }}$}

Com os dados mensurados em campo foram elaborados croquis com a projeção de copa de cada uma das árvores amostradas na parcela de inventário, conforme apresentado nas Figuras 54 a 56 a seguir. 


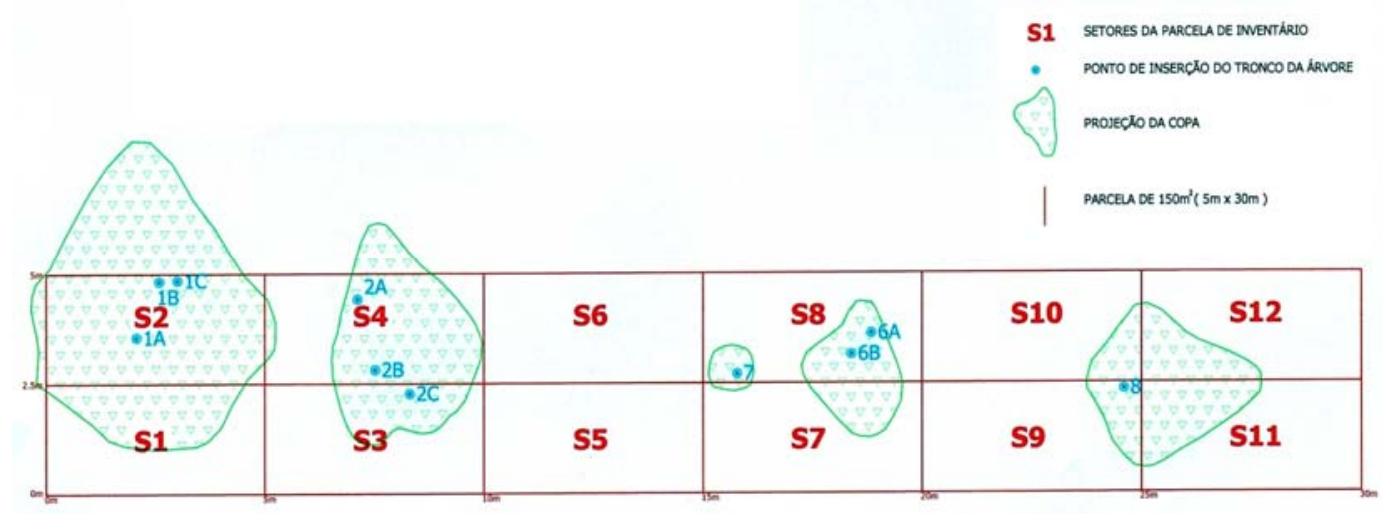

Figura 54 - Parcela de inventário com projeção de copa no Canal da Cosipa

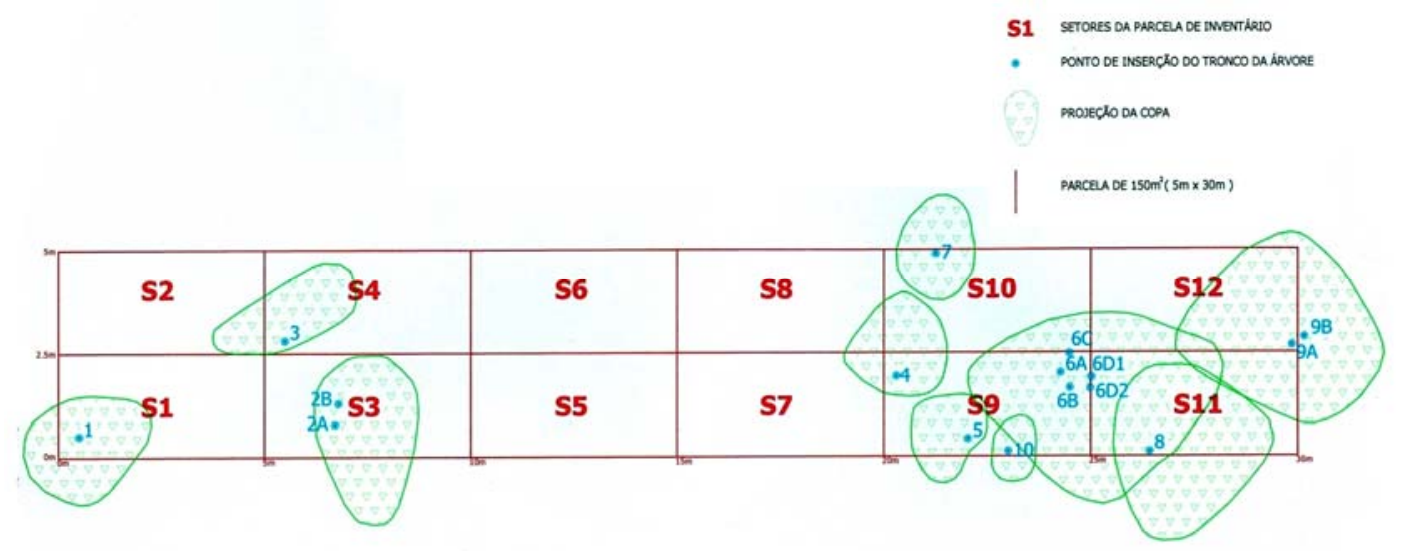

Figura 55 - Parcela de inventário com projeção de copa no Rio Cascalho

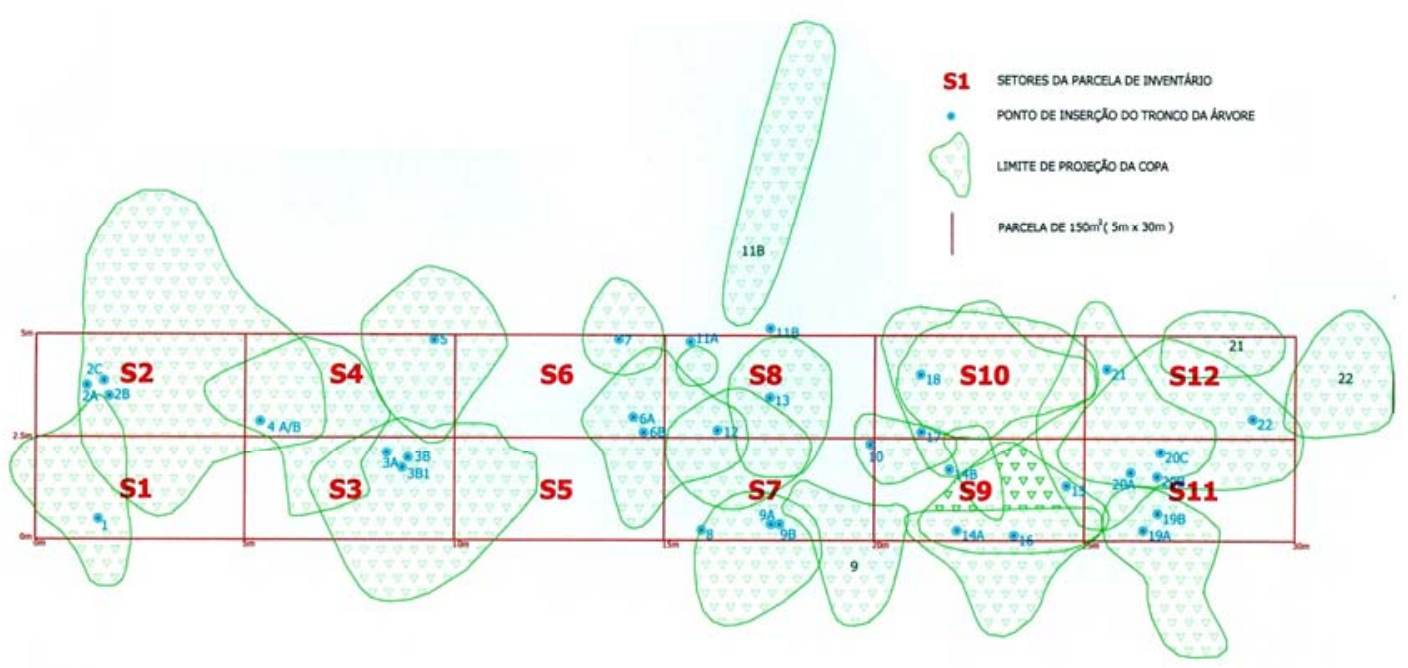

Figura 56 - Parcela de inventário com projeção de copa no Rio Mariana 
À semelhança daquilo que foi avaliado para as árvores matrizes, para as árvores da parcela de inventário constata-se que as copas das árvores de $R$. mangle são em geral irregulares e frequentemente deslocadas em relação ao tronco principal e para a $A$. shaueriana, apesar de uma certa irregularidade, a estrutura da copa é no geral mais uniforme.

Corroborando as conclusões da avaliação com base no perfil horizontal (item anterior), um dossel comparativamente mais fechado é característica do bosque do Rio Mariana, seguido do Rio Cascalho e por fim o Canal da Cosipa.

Esta condição pode afetar a incidência luminosa no sub-bosque, influenciando as condições ambientais quanto ao desenvolvimento das mudas. Adicionalmente, a situação de maior porosidade da mata devido à baixa densidade do bosque afeta também a regeneração no sentido de que as árvores com sua trama de raízes minimizam a força de arraste das águas das marés e funcionam como barreiras de retenção aos propágulos que podem estar chegando à área via flutuação ou ainda dificultar a saída de propágulos produzidos no próprio local.

\section{Caracterização do bosque - avaliação de indivíduos adultos}

A caracterização do bosque em relação à situação dos indivíduos adultos, quanto aos parâmetros mensurados, foi analisada estatisticamente considerando as duas espécies presentes (de forma conjunta) para comparação de áreas - Tabela 21 e a comparação das áreas para cada uma das espécies individualmente - Tabela 22, conforme apresentado na seqüência. 
Tabela 21. Indivíduos adultos de R. mangle e A. shaueriana avaliados conjuntamente

\begin{tabular}{|c|c|c|c|c|c|c|}
\hline \multicolumn{7}{|c|}{ Adultos I ambas as espécies I área } \\
\hline Parâmetro & \multicolumn{3}{|c|}{ Análise de Variância } & \multicolumn{3}{|c|}{$\begin{array}{c}\text { Teste de Tukey } \\
\text { (5\% de probabilidade) }\end{array}$} \\
\hline \multirow{2}{*}{ Número de brotos } & 2,76 & 37,42 & $0,0001 * *$ & $\mathrm{RC}$ & 4,11 & a \\
\hline & & & & RM & 1,99 & $\mathrm{c}$ \\
\hline \multirow{3}{*}{ Altura da raiz (m) } & 125 & 87.72 & 0.0001 ** & RM & 1,85 & a \\
\hline & $1, \angle J$ & 01,12 & $0,000 \perp$ & $\mathrm{CC}$ & 1,22 & b \\
\hline & & & & $\mathrm{RC}$ & 0,07 & c \\
\hline \multirow{3}{*}{ Altura da árvore (m) } & 6.95 & 1426 & 00001 ** & RM & 7,63 & a \\
\hline & ד & $14, \angle 0$ & $0,000 \perp$ & $\mathrm{RC}$ & 6,22 & b \\
\hline & & & & $\mathrm{CC}$ & 5,96 & b \\
\hline \multirow{3}{*}{ Altura do fuste (m) } & 3.25 & 16.91 & $0.0001 * *$ & RM & 3,72 & a \\
\hline & & & & CC & 3.01 & b \\
\hline & & & & $\mathrm{RC}$ & 2,45 & b \\
\hline \multirow{3}{*}{ Altura da copa (m) } & 3.50 & 3.03 & $0.0503 \mathrm{~ns}$ & RM & 3,73 & a \\
\hline & , & 6,0 & שוד שלטס, & $\mathrm{RC}$ & 3,38 & $a b$ \\
\hline & & & & $\mathrm{CC}$ & 3,00 & b \\
\hline \multirow[t]{2}{*}{ DAP (cm) } & 7,93 & 23,02 & $0,0001 * *$ & RM & 8,84 & a \\
\hline & & & & RC & $\begin{array}{l}7,16 \\
6,59\end{array}$ & $\begin{array}{l}\mathrm{b} \\
\mathrm{b}\end{array}$ \\
\hline \multirow{3}{*}{ Projeção média da copa (m) } & 237 & 300 & 0 0217 * & $\mathrm{CC}$ & 2,48 & $\mathrm{a}$ \\
\hline & 2,01 & 0,50 & $0,0<1 r$ & RM & 2,47 & $a$ \\
\hline & & & & $\mathrm{RC}$ & 2,12 & $\mathrm{a}$ \\
\hline
\end{tabular}

Legenda: Teste de Tukey para comparação de médias entre Áreas: CC - Canal da Cosipa; RM - Rio Marina; RC - Rio Cascalho 
Tabela 22. Indivíduos adultos de R. mangle e A. shaueriana avaliados individualmente

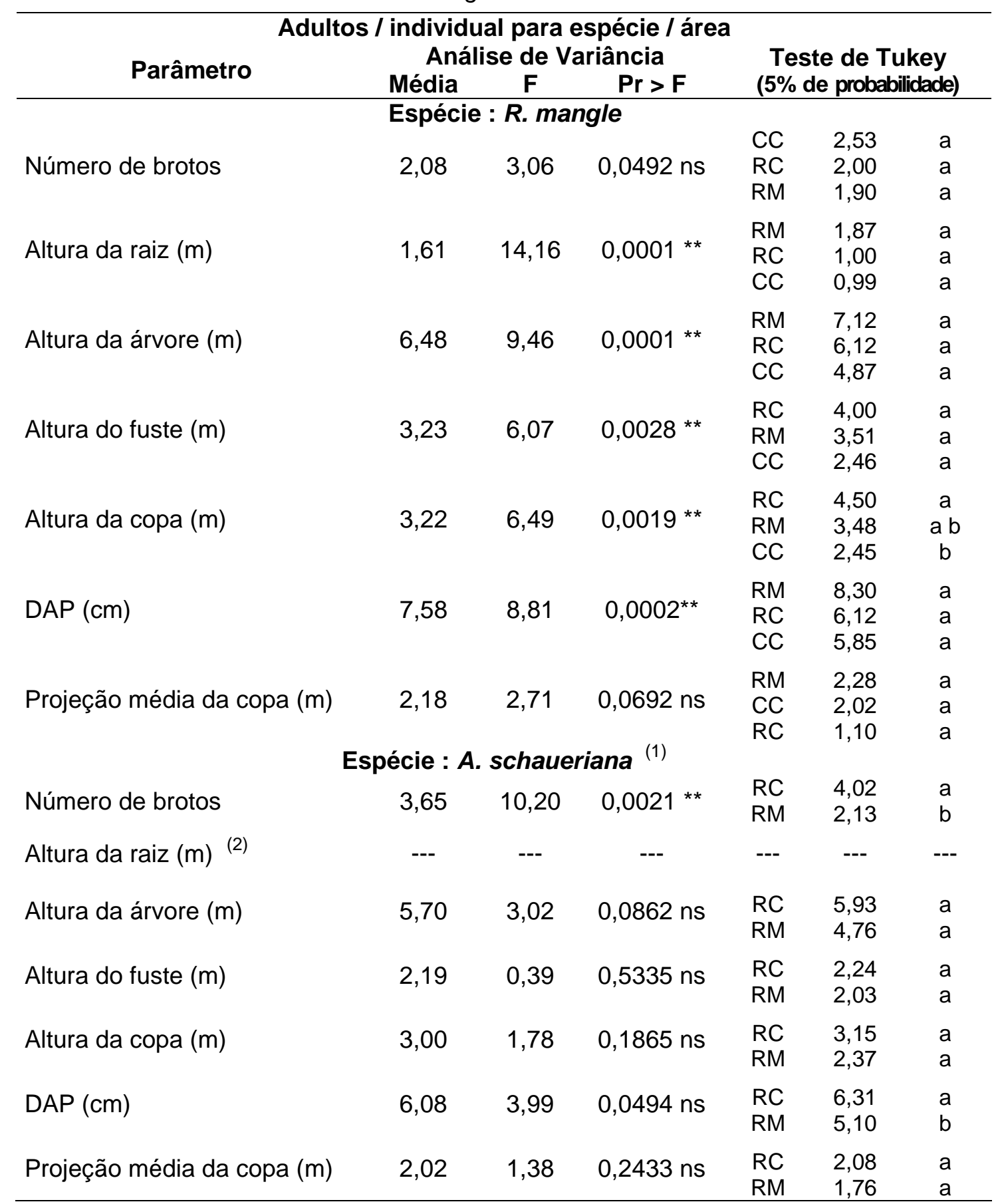

(1) Espécie ausente na parcela na área do Canal da Cosipa (2) Espécie sem raiz escora Teste de Tukey para médias de Áreas: CC-Canal da Cosipa; RM-Rio Marina; RC-Rio Cascalho Obs.: Para as variáveis $\mathrm{N}^{0}$. de brotos, altura da raiz e do fuste e DAP da espécie $R$. mangle, o Teste de Tukey não foi o melhor teste, havendo incoerências entre este e o resultado da análise de variância, porém este foi aplicado para padronizar as análises. 
Da Tabela 21 verifica-se que quando da avaliação conjunta das espécies amostradas, os parâmetros relacionados à copa apresentaram menor diferenciação entre as áreas, pois a altura de copa não foi significativa e a projeção média da copa foi significativa a $5 \%$ de probabilidade. Os demais parâmetros foram todos altamente significativos (1\%), mostrando que as áreas apresentam diferenças em relação às características dos indivíduos que compõem o bosque.

No que se refere à altura da raiz, altura da árvore, altura do fuste e DAP, o Rio Mariana apresenta as maiores médias, seguido do Canal da Cosipa (para fuste, raiz e DAP) e, o Rio Cascalho apresenta a segunda maior média para altura da árvore. Ao contrário, o Rio Mariana apresenta a menor média em para o número de brotos (as árvores com maior número de brotos estão no Rio Cascalho e Canal da Cosipa). Estas características podem então ser consideradas diferenciadoras do bosque nas três áreas, ficando o número de brotos em média por volta de 2 à 3 / árvore; a altura média da raiz (para $R$. mangle) de 1,25m; a altura da árvore na média próximo de 7,00m e do fuste em $3,25 \mathrm{~m}$; DAP médio próximo de $8,00 \mathrm{~cm}$ e a projeção média da copa de $3,37 \mathrm{~m}$.

Quando se individualiza os dados para cada uma das espécies (Tabela 22), constata-se que a espécie $A$. shaueriana não é responsável pela diferenciação do bosque nas áreas, pois a única característica com significância foi o número de brotos (e a espécie não figura na parcela do Canal da Cosipa). Assim, a $R$. mangle é a planta cujas características das árvores tornam o bosque das áreas amostradas diferentes entre si, com valores médios de 2 brotos/árvore; altura da raiz de 1,61m e da árvore de 6,50m e DAP de 7,58cm.

Para a $R$. mangle, apenas o número de brotos e a projeção de copa não foram significativos, porém todas as demais características apresentam-se altamente significativas, com o Rio Mariana em geral apresentando as maiores médias, com árvores e raizadas mais altas, maiores DAPs e com a segunda melhor posição em relação a altura do fuste e altura da copa. 
Estabelecimento de indivíduos jovens sob as árvores da parcela de inventário

A regeneração foi avaliada considerando a quantidade de propágulos e indivíduos jovens (mudas até $80 \mathrm{~cm}$ de altura e mudas maiores que $80 \mathrm{~cm}$ de altura e com DAP $<5 \mathrm{~cm}$, considerado o limite de medição dos indivíduos adultos). Os resultados obtidos foram analisados de forma conjunta e individualmente para as espécies $R$. mangle e $A$. shaueriana visando a comparação entre as áreas e entre as espécies, conforme apresentado nas Tabelas 23 a 25 a seguir.

Tabela 23. Propágulos e mudas de $R$. mangle e $A$. shaueriana avaliados conjuntamente

\begin{tabular}{|c|c|c|c|c|c|c|}
\hline & $\begin{array}{l}\text { ens / am } \\
\text { Aná }\end{array}$ & $\begin{array}{l}\text { as es } \\
\text { de Va }\end{array}$ & $\begin{array}{l}\text { cies / área } \\
\text { incia }\end{array}$ & & e de T & \\
\hline Parâmetro & Média & $F$ & $\mathrm{Pr}>\mathrm{F}$ & $(5 \%$ & probal & ade) \\
\hline Propágulos enraizados & 2,08 & 16,09 & 0,0001 ** & $\begin{array}{l}\text { RM } \\
\text { RC } \\
\text { CC }\end{array}$ & $\begin{array}{l}4,12 \\
1,71 \\
0,42\end{array}$ & $\begin{array}{l}a \\
b \\
b\end{array}$ \\
\hline Propágulos superficiais & 3,75 & 35,35 & 0,0001 ** & $\begin{array}{l}\text { RM } \\
\text { RC } \\
\text { CC }\end{array}$ & $\begin{array}{l}8,42 \\
1,56 \\
1,27\end{array}$ & $\begin{array}{l}a \\
b \\
b\end{array}$ \\
\hline Mudas até $80 \mathrm{~cm}$ & 29,16 & 7,12 & $0,0010 * *$ & $\begin{array}{l}\text { RC } \\
\text { RM } \\
\text { CC }\end{array}$ & $\begin{array}{c}63,39 \\
18,41 \\
5,69\end{array}$ & $\begin{array}{l}a \\
b \\
b\end{array}$ \\
\hline Mudas $>80 \mathrm{~cm}$ & 5,23 & 9,12 & $0,0001 * *$ & $\begin{array}{l}\text { RC } \\
\text { CC } \\
\text { RM }\end{array}$ & $\begin{array}{l}6,59 \\
5,35 \\
3,75\end{array}$ & $\begin{array}{l}a \\
a \\
b\end{array}$ \\
\hline
\end{tabular}

Legenda: Teste de Tukey para comparação de médias entre Áreas:

CC - Canal da Cosipa; RM - Rio Marina; RC - Rio Cascalho 
Tabela 24. Propágulos e mudas de R. mangle e $A$. shaueriana avaliados individualmente

\begin{tabular}{|c|c|c|c|c|c|c|}
\hline \multicolumn{7}{|c|}{ Jovens / individual para espécie / área } \\
\hline \multirow{2}{*}{ Parâmetro } & \multicolumn{3}{|c|}{ Análise de Variância } & \multirow{2}{*}{\multicolumn{3}{|c|}{$\begin{array}{c}\text { Teste de Tukey } \\
\text { (5\% de probabilidade) }\end{array}$}} \\
\hline & Média & $\mathbf{F}$ & $\operatorname{Pr}>\mathrm{F}$ & & & \\
\hline \multicolumn{7}{|c|}{ Espécie : R. mangle } \\
\hline \multirow[t]{2}{*}{ Propágulo enraizado } & 2,08 & 16,09 & $0,0001 * \star$ & $\begin{array}{l}\text { RM } \\
\text { RC }\end{array}$ & $\begin{array}{l}4,12 \\
1,71\end{array}$ & $\begin{array}{l}a \\
b\end{array}$ \\
\hline & & & & $\mathrm{CC}$ & 0,42 & $\mathrm{~b}$ \\
\hline \multirow{3}{*}{ Propágulo superficial } & 375 & 2535 & 0 & RM & 8,42 & $\mathrm{a}$ \\
\hline & 3,15 & 35,35 & $0,000 \perp$ & $\mathrm{RC}$ & 1,56 & $\mathrm{~b}$ \\
\hline & & & & $\mathrm{CC}$ & 1,27 & b \\
\hline \multirow[t]{2}{*}{ Mudas até $80 \mathrm{~cm}$} & 8,89 & 29,55 & $0,0001 * *$ & RM & 15,70 & a \\
\hline & & & & $\begin{array}{l}\mathrm{CC} \\
\mathrm{RC}\end{array}$ & $\begin{array}{l}8,60 \\
2,35\end{array}$ & $\begin{array}{l}\mathrm{b} \\
\mathrm{c}\end{array}$ \\
\hline \multirow{3}{*}{ Mudas $>80 \mathrm{~cm}$} & 790 & ه० & $02766 n c$ & $\mathrm{CC}$ & 8,50 & $\mathrm{a}$ \\
\hline & & 0,90 & & $\mathrm{RC}$ & 8,29 & a \\
\hline & & & & RM & 6,92 & a \\
\hline \multicolumn{7}{|c|}{ Espécie : A. schaueriana } \\
\hline Propágulo enraizado & -- & -- & -- & \multicolumn{3}{|c|}{ não avaliado } \\
\hline Propágulo superficial & -- & -- & -- & \multicolumn{3}{|c|}{ não avaliado } \\
\hline \multirow{2}{*}{ Mudas até $80 \mathrm{~cm}$} & \multirow{2}{*}{49,43} & \multirow{2}{*}{8,90} & \multirow{2}{*}{$0,0002 * \star$} & $\mathrm{RC}$ & 124,42 & $\mathrm{a}$ \\
\hline & & & & $\begin{array}{l}\text { RM } \\
\mathrm{CC}\end{array}$ & $\begin{array}{c}21,10 \\
2,77\end{array}$ & $\begin{array}{l}\mathrm{b} \\
\mathrm{b}\end{array}$ \\
\hline \multirow{3}{*}{ Mudas $>80 \mathrm{~cm}$} & \multirow{3}{*}{2,53} & \multirow{3}{*}{39,12} & \multirow{3}{*}{0,0001 ** } & $\mathrm{RC}$ & 4,85 & $\mathrm{a}$ \\
\hline & & & & $\mathrm{CC}$ & 2,21 & $\mathrm{~b}$ \\
\hline & & & & RM & 0,58 & $\mathrm{c}$ \\
\hline
\end{tabular}

Legenda: Teste de Tukey para comparação de médias entre Áreas: CC - Canal da Cosipa; RM - Rio Marina; RC - Rio Cascalho. 
Tabela 25. Comparação de mudas de R. mangle e A. shaueriana

\begin{tabular}{|c|c|c|c|c|c|c|}
\hline & \multicolumn{3}{|c|}{$\begin{array}{c}\text { Jovens / comparação entre as espécie } \\
\text { Análise de Variância }\end{array}$} & \multirow{2}{*}{\multicolumn{3}{|c|}{$\begin{array}{l}\text { Seste de Tukey } \\
\text { (5\% de probabilidade) }\end{array}$}} \\
\hline Parametro & Média & $\mathbf{F}$ & $\operatorname{Pr}>\mathrm{F}$ & & & \\
\hline Mudas até $80 \mathrm{~cm}$ & 29,16 & 9,55 & 0,0022 ** & $\begin{array}{l}\text { As } \\
\mathrm{Rm}\end{array}$ & $\begin{array}{c}49,43 \\
8,89\end{array}$ & $\begin{array}{l}\mathrm{a} \\
\mathrm{b}\end{array}$ \\
\hline Mudas $>80 \mathrm{~cm}$ & 5,23 & 9,12 & $0,0001 * *$ & $\begin{array}{l}\mathrm{Rm} \\
\text { As }\end{array}$ & $\begin{array}{l}7,90 \\
2,53 \\
\end{array}$ & $\begin{array}{l}\mathrm{a} \\
\mathrm{b}\end{array}$ \\
\hline
\end{tabular}

Legenda: Teste de Tukey para comparação de médias entre Espécies: $\mathrm{Rm}-$ R. mangle As - A. shaueriana

Das três Tabelas que apresentam os resultados para a regeneração nas parcelas de inventário pode-se observar que praticamente todos os parâmetros (única exceção mudas $>80 \mathrm{~cm}$ para $R$. mangle - Tabela 24) foram altamente significativos, indicando que tanto as áreas quanto as espécies avaliadas apresentam diferenças consideráveis entre si.

Para propágulos, a avaliação foi feita somente para $R$. mangle pois os propágulos da $A$. shaueriana são muito pequenos, impossibilitando a percepção de superficialidade ou enraizamento no solo lodoso do Manguezal. Assim, a média obtida foi próxima de 2 propágulos de $R$. mangle enraizados e 2 a 3 propágulos superficiais/área, com as maiores quantidades no Rio Mariana, seguido do Rio Cascalho e Canal da Cosipa, possivelmente devido aos efeitos das marolas que arrastam e arrancam os propágulos nesta última área.

Em relação às mudas, a média é de aproximadamente 30 mudas até 80cm/área e de 5 mudas/área, considerando ambas as espécies conjuntamente. Porém, a análise individual para espécies revela que há uma quantidade muito superior de mudas pequenas de $A$. shaueriana (em média quase 50 mudas/área) em comparação com a $R$. mangle (média inferior a 9 mudas/área) e, ao contrário, as mudas com altura maior que $80 \mathrm{~cm}$ são mais freqüentes para R. mangle (média de quase 8 mudas/área) do que para $A$. shaueriana, cuja 
média é muito inferior (aproximadamente 2,5 mudas/área). Para as áreas, na avaliação indistinta por espécie, o Rio Cascalho figura com as melhores médias para as duas alturas de mudas, tendência que se repete para a $A$. shaueriana, mas para $R$. mangle as mudas pequenas são mais abundantes no Rio Mariana e quanto àquelas com altura superior a $80 \mathrm{~cm}$ as áreas não apresentaram diferença significativa.

Quando se compara somente as espécies sem considerar as áreas, a situação se comprova, com a $A$. shaueriana apresentando média muito superior para mudas até $80 \mathrm{~cm}(29,16)$ e a $R$. mangle apresentando a maior média para mudas de altura inferior a $80 \mathrm{~cm}(5,22)$.

\subsection{Plantio de propágulos}

Situação das áreas de plantio

Nas Figuras 57 a 71, a seguir são apresentadas fotos da área de plantio e das mudas nas diferentes avaliações para ilustrar a situação nas quatro áreas de estudo. As fotos ilustram também a regeneração natural nestas áreas. 


\section{Canal da Cosipa}

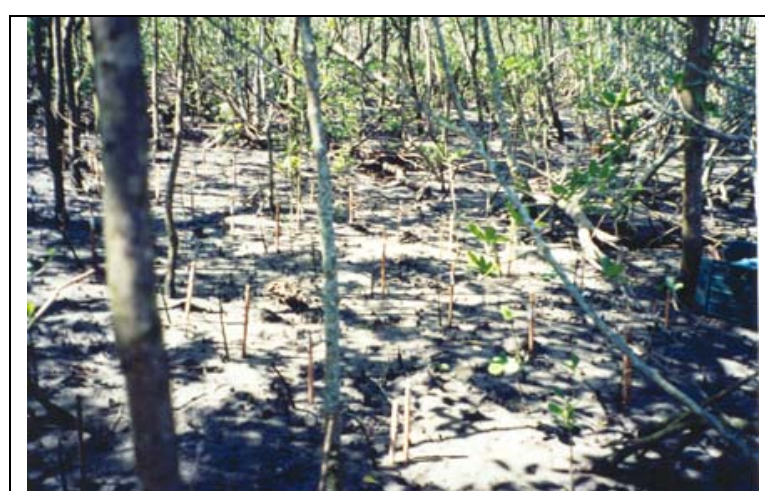

Figura 57 - Parcela do primeiro plantio no Canal da Cosipa

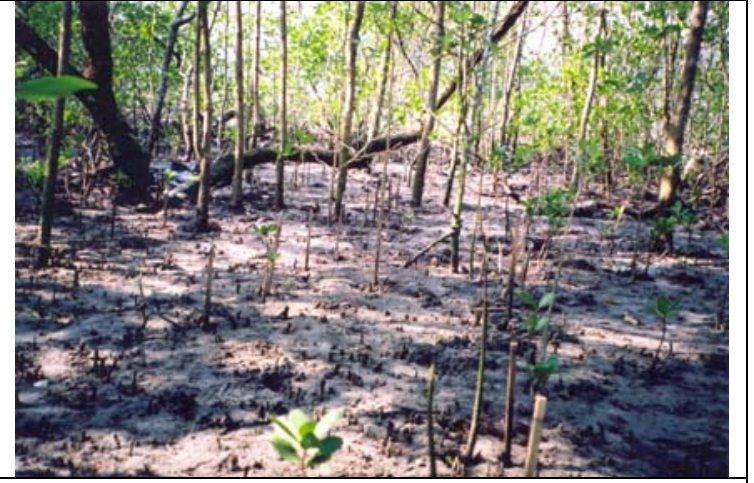

Figura 58 - Parcela do segundo plantio no Canal da Cosipa

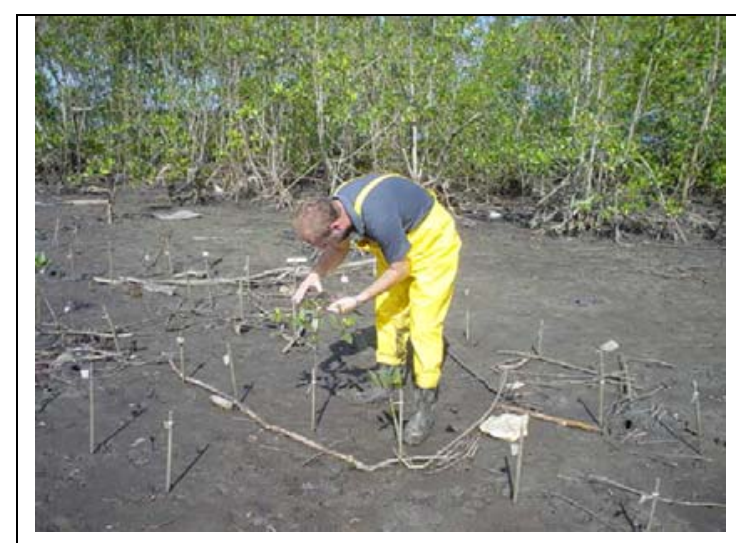

Figura 59 - Avaliação do terceiro plantio no Canal da Cosipa

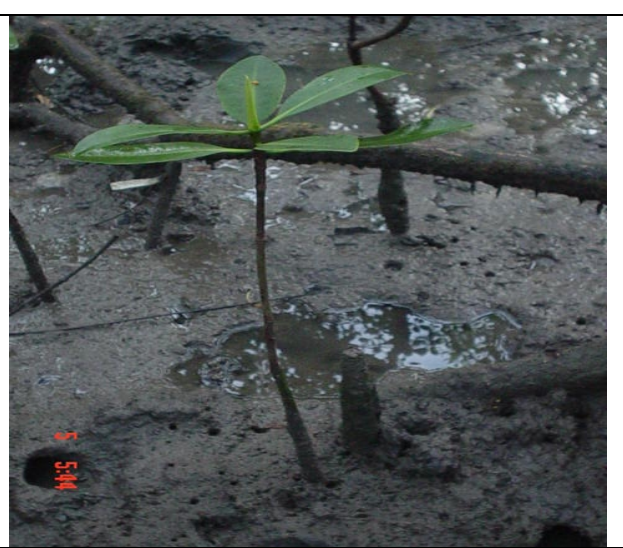

Figura 60 - Regeneração natural no Canal da Cosipa 


\section{Rio Cascalho}

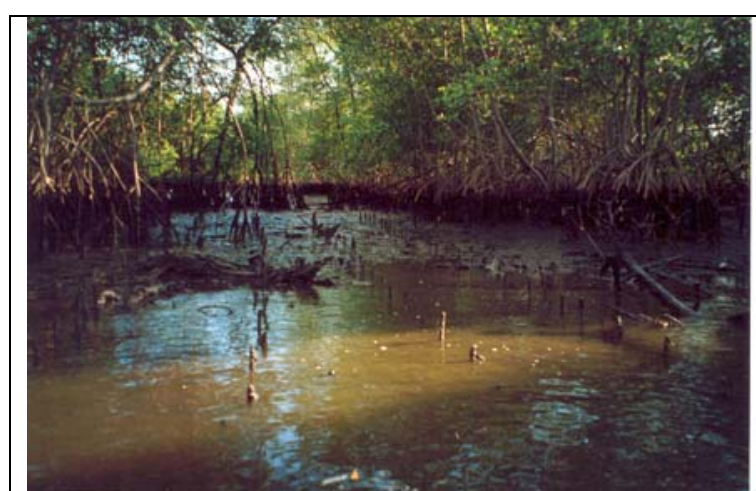

Figura 61 - Parcela do primeiro plantio no Rio Cascalho (maré alta)

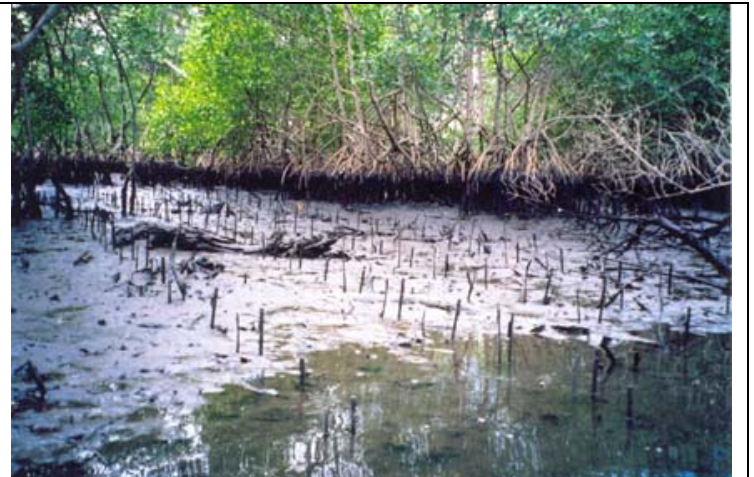

Figura 62 - Parcela do primeiro plantio no Rio Cascalho (maré vazante)

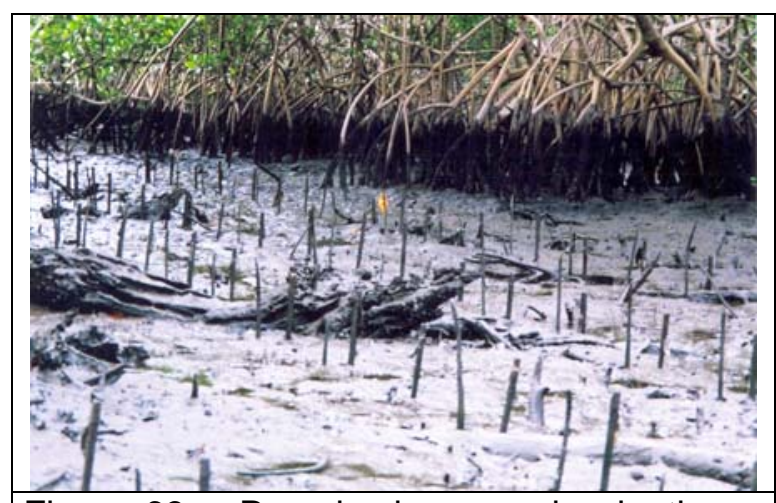

Figura 63 - Parcela do segundo plantio no Rio Cascalho na última avaliação - alta mortalidade

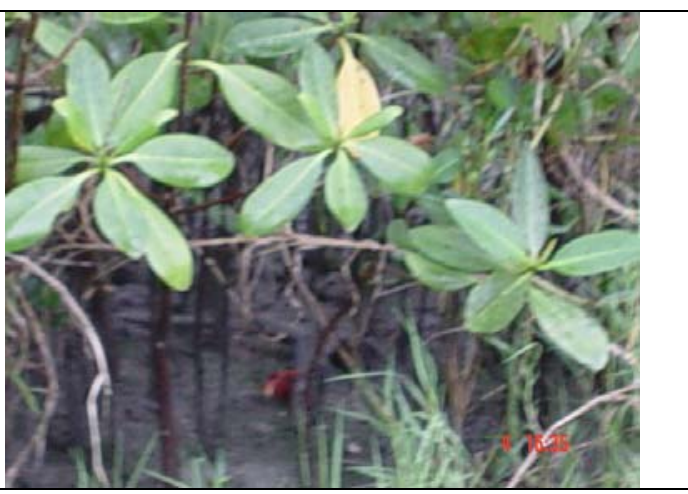

Figura 64 - Regeneração natural no Rio Cascalho 


\section{Rio Mariana}

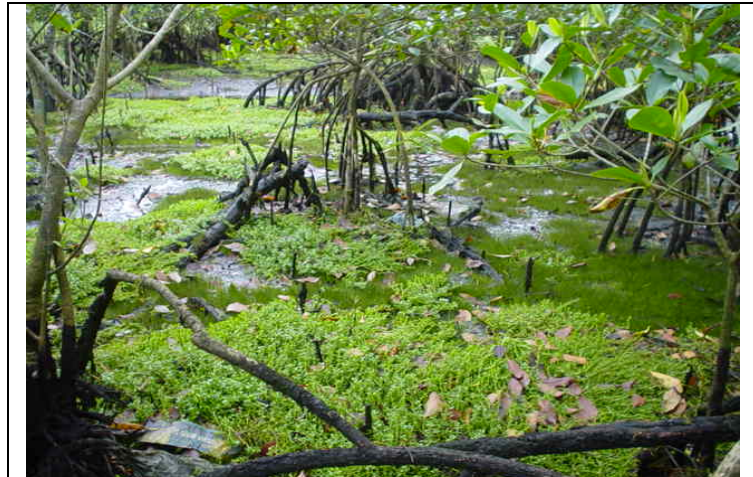

Figura 65 - Parcela do primeiro plantio no Rio Mariana

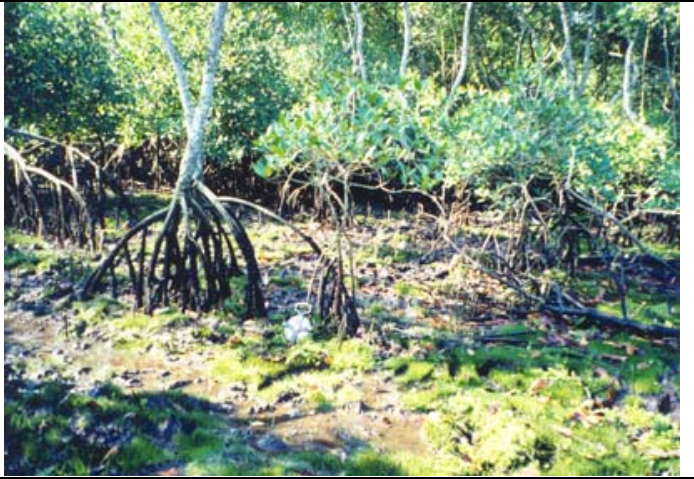

Figura 66 - Parcela do primeiro plantio no Rio Mariana na avaliação final - alta mortalidade
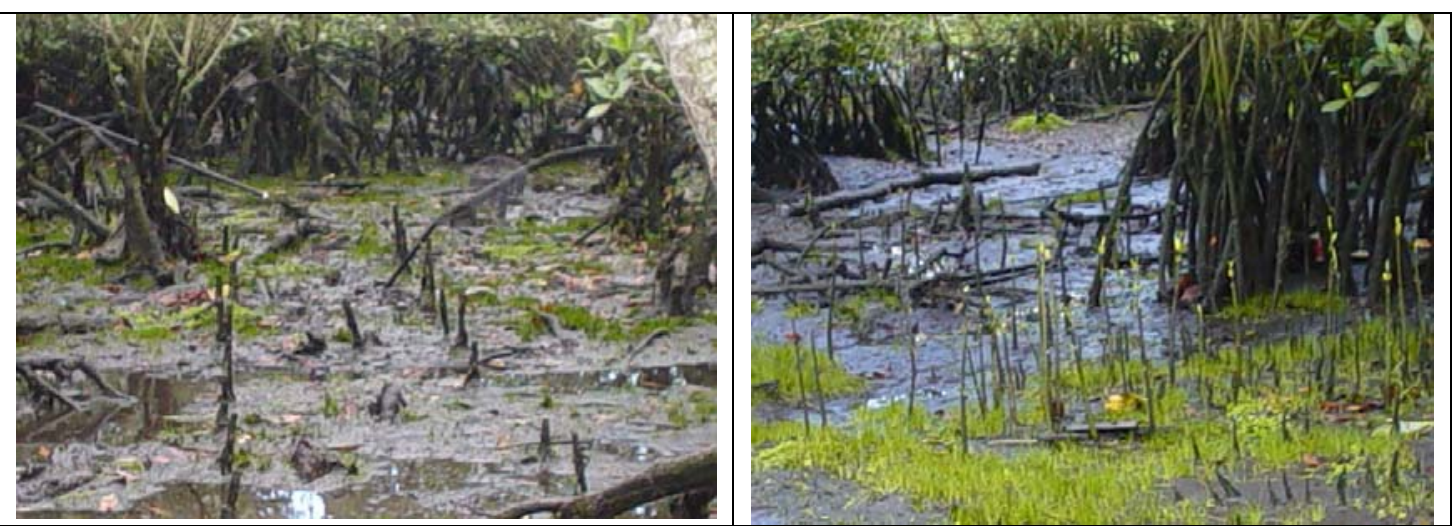

Figura 67 - Parcela do segundo plantio no Figura 68 - Regeneração natural no Rio Rio Mariana (restaram somente as Mariana estacas) 
Ilha do Cardoso

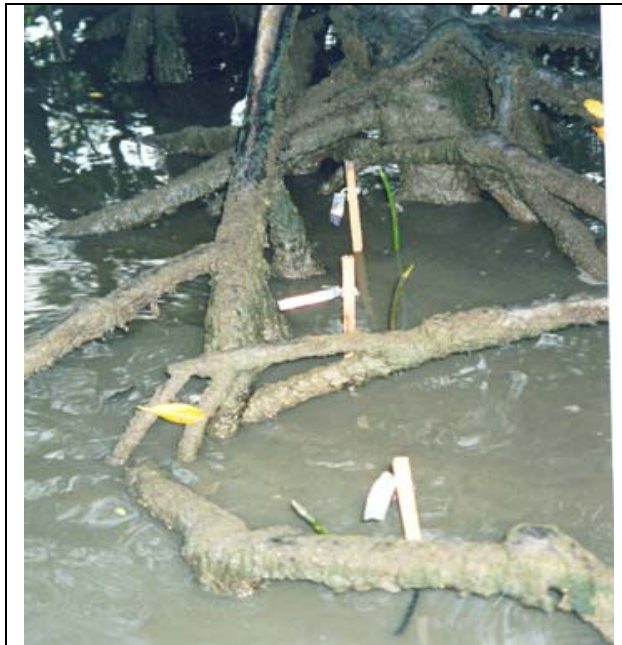

Figura 69 - Parcela de plantio na Ilha do Cardoso (maré cheia)

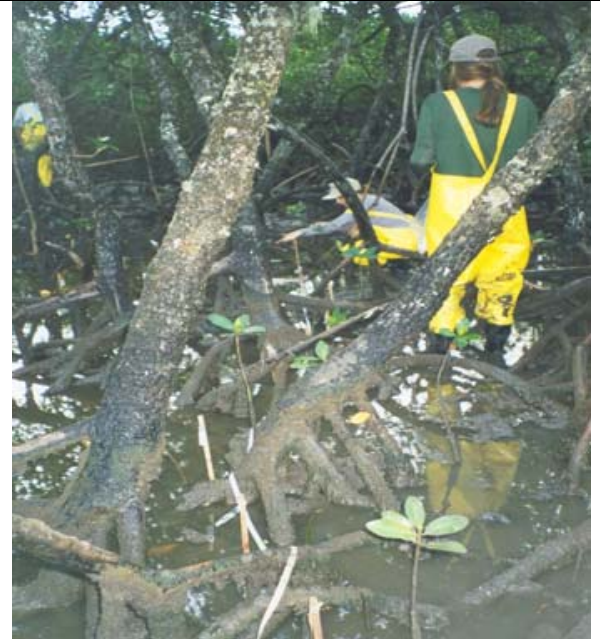

Figura 70 - Parcela de plantio na Ilha do Cardoso (maré vazante), na avaliação final

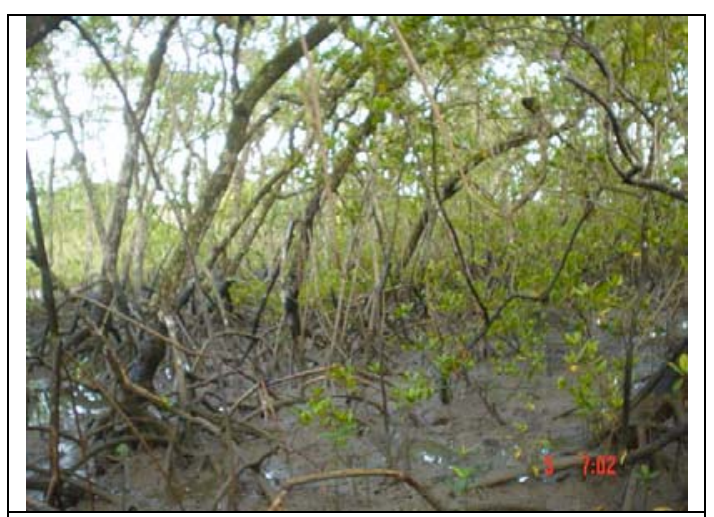

Figura 71 - Regeneração natural na Ilha do Cardoso 
Taxa de mortalidade

Os propágulos coletados na própria área e na área testemunha foram plantados e seu desenvolvimento acompanhado periodicamente em avaliações aproximadamente semestrais. Devido a perdas no plantio, replantios de novas áreas foram viabilizados, procedendo-se também o acompanhamento do desenvolvimento das mudas. Para os dados obtidos nas subseqüentes avaliações foi calculada a taxa de mortalidade e sobrevivência, conforme apresentado nas Tabelas 26 a 29.

Tabela 26. Taxa de mortalidade e sobrevivência para o Canal da Cosipa

\begin{tabular}{|c|c|c|c|c|c|c|c|c|}
\hline \multirow[b]{3}{*}{ Evento } & \multirow{3}{*}{$\begin{array}{c}\mathbf{N}^{\mathbf{O}} \\
\text { Mudas } \\
\text { CC }\end{array}$} & \multicolumn{4}{|c|}{ PRIMEIRO PLANTIO } & \multirow{2}{*}{\multicolumn{3}{|c|}{ Taxa de Sobrevivência }} \\
\hline & & \multirow{2}{*}{$\begin{array}{c}\mathrm{N}^{\circ} \\
\text { Mudas } \\
\text { IC }\end{array}$} & \multicolumn{3}{|c|}{ Taxa de Mortalidade } & & & \\
\hline & & & $\mathrm{CC}$ & IC & Área & cc & IC & Área \\
\hline $1^{\circ}$ Plantio - 25/04/02 & 50 & 50 & -- & -- & -- & -- & -- & -- \\
\hline $\begin{array}{c}1^{\circ} \text { Av. }-25 / 07 / 02 \\
(3 \text { meses })\end{array}$ & 10 & 5 & $80 \%$ & $90 \%$ & $85 \%$ & $20 \%$ & $10 \%$ & $15 \%$ \\
\hline $\begin{array}{c}2^{\circ} \mathbf{A v} . \\
\text { (Não houve) }\end{array}$ & - & - & - & - & - & - & - & - \\
\hline \multicolumn{9}{|c|}{ SEGUNDO PLANTIO } \\
\hline $\begin{array}{c}2^{\circ} \text { Plantio } \\
25 / 07 / 02\end{array}$ & 50 & 50 & -- & -- & -- & -- & -- & -- \\
\hline $\begin{array}{c}1^{\circ} \text { Av. - 10/02/03 } \\
(7 \text { meses })\end{array}$ & 14 & 0 & $72 \%$ & $100 \%$ & $72 \%$ & $28 \%$ & $0 \%$ & $28 \%$ \\
\hline $\begin{array}{c}2^{\circ} \mathbf{A v} . \\
\text { (Não houve) }\end{array}$ & -- & -- & -- & -- & -- & -- & -- & -- \\
\hline \multicolumn{9}{|c|}{ TERCEIRO PLANTIO } \\
\hline $\begin{array}{c}3^{\circ} \text {. Plantio } \\
10 / 02 / 03\end{array}$ & 50 & 50 & -- & -- & -- & -- & -- & -- \\
\hline $\begin{array}{c}1^{\circ} \text { Av. }-13 / 08 / 03 \\
(6 \text { meses })\end{array}$ & 5 & 11 & $90 \%$ & $78 \%$ & $84 \%$ & $10 \%$ & $22 \%$ & $16 \%$ \\
\hline $\begin{array}{c}2^{\circ} \text { Av. }-16 / 03 / 04 \\
(7 \text { meses })\end{array}$ & 3 & 1 & $94 \%$ & $98 \%$ & $96 \%$ & $6 \%$ & $2 \%$ & $4 \%$ \\
\hline
\end{tabular}


Tabela 27. Taxa de mortalidade e sobrevivência para o Rio Cascalho

\begin{tabular}{|c|c|c|c|c|c|c|c|c|}
\hline \multirow[b]{3}{*}{ Evento } & \multicolumn{5}{|c|}{ PRIMEIRO PLANTIO } & \multirow{2}{*}{\multicolumn{3}{|c|}{ Taxa de Sobrevivência }} \\
\hline & \multirow{2}{*}{$\begin{array}{c}\mathbf{N}^{\mathbf{O}} \\
\text { Mudas } \\
\text { CC }\end{array}$} & \multirow{2}{*}{$\begin{array}{c}\mathbf{N}^{\circ} \\
\text { Mudas } \\
\text { IC }\end{array}$} & \multicolumn{3}{|c|}{ Taxa de Mortalidade } & & & \\
\hline & & & $\mathrm{RC}$ & IC & Área & $\mathrm{RC}$ & IC & Área \\
\hline $\begin{array}{l}1^{\circ} \text {. Plantio } \\
25 / 04 / 02\end{array}$ & 50 & 50 & -- & -- & -- & -- & -- & -- \\
\hline $\begin{array}{c}1^{\circ} \mathrm{Av} .-10 / 02 / 03 \\
(9 \text { meses })\end{array}$ & 3 & 1 & $94 \%$ & $98 \%$ & $92 \%$ & $6 \%$ & $2 \%$ & $8 \%$ \\
\hline $\begin{array}{c}2^{\circ} \mathrm{Av.} \\
\text { (Não houve) }\end{array}$ & -- & -- & -- & -- & -- & -- & -- & -- \\
\hline \multicolumn{9}{|c|}{ SEGUNDO PLANTIO } \\
\hline $\begin{array}{l}2^{\circ} \text {. Plantio } \\
10 / 02 / 03\end{array}$ & 50 & 50 & -- & -- & -- & -- & -- & -- \\
\hline $\begin{array}{c}1^{\circ} \text { Av. }-11 / 08 / 03 \\
(6 \text { meses })\end{array}$ & 25 & 21 & $50 \%$ & $58 \%$ & $54 \%$ & $50 \%$ & $42 \%$ & $46 \%$ \\
\hline $\begin{array}{c}2^{\circ} \text { Av. - 16/03/04 } \\
(8 \text { meses) }\end{array}$ & 15 & 8 & $70 \%$ & $84 \%$ & $77 \%$ & $30 \%$ & $16 \%$ & $23 \%$ \\
\hline
\end{tabular}

Tabela 28. Taxa de mortalidade e sobrevivência para o Rio Mariana

\begin{tabular}{|c|c|c|c|c|c|c|c|c|}
\hline \multirow[b]{3}{*}{ Evento } & \multicolumn{5}{|c|}{ PRIMEIRO PLANTIO } & \multirow{2}{*}{\multicolumn{3}{|c|}{ Taxa de Sobrevivência }} \\
\hline & \multirow{2}{*}{$\begin{array}{c}N^{\circ} \\
\text { Mudas } \\
\text { CC }\end{array}$} & \multirow{2}{*}{$\begin{array}{c}N^{\circ} \\
\text { Mudas } \\
\text { IC }\end{array}$} & \multicolumn{3}{|c|}{ Taxa de Mortalidade } & & & \\
\hline & & & RC & IC & Área & RC & IC & Área \\
\hline $\begin{array}{c}1^{\circ} \text {. Plantio } \\
26 / 04 / 02\end{array}$ & 50 & 50 & -- & -- & -- & -- & -- & -- \\
\hline $\begin{array}{c}1^{\circ} \mathrm{Av} .-10 / 02 / 03 \\
(10 \text { meses })\end{array}$ & 0 & 0 & $100 \%$ & $100 \%$ & $100 \%$ & $0 \%$ & $0 \%$ & $0 \%$ \\
\hline $\begin{array}{c}\mathbf{2}^{\circ} \mathbf{A v} . \\
\text { (Não houve) }\end{array}$ & -- & -- & -- & -- & -- & -- & -- & -- \\
\hline \multicolumn{9}{|c|}{ SEGUNDO PLANTIO } \\
\hline $\begin{array}{c}2^{\circ} \text {. Plantio } \\
10 / 02 / 03\end{array}$ & 50 & 50 & -- & -- & -- & -- & -- & -- \\
\hline $\begin{array}{c}1^{\circ} \text { Av. - 12/08/03 } \\
(6 \text { meses })\end{array}$ & 0 & 0 & $100 \%$ & $100 \%$ & $100 \%$ & $0 \%$ & $0 \%$ & $0 \%$ \\
\hline $\begin{array}{c}2^{\circ} \text { Av. } \\
\text { (Não houve) }\end{array}$ & -- & -- & -- & -- & -- & -- & -- & -- \\
\hline
\end{tabular}


Tabela 29. Taxa de mortalidade e sobrevivência para a Ilha do Cardoso

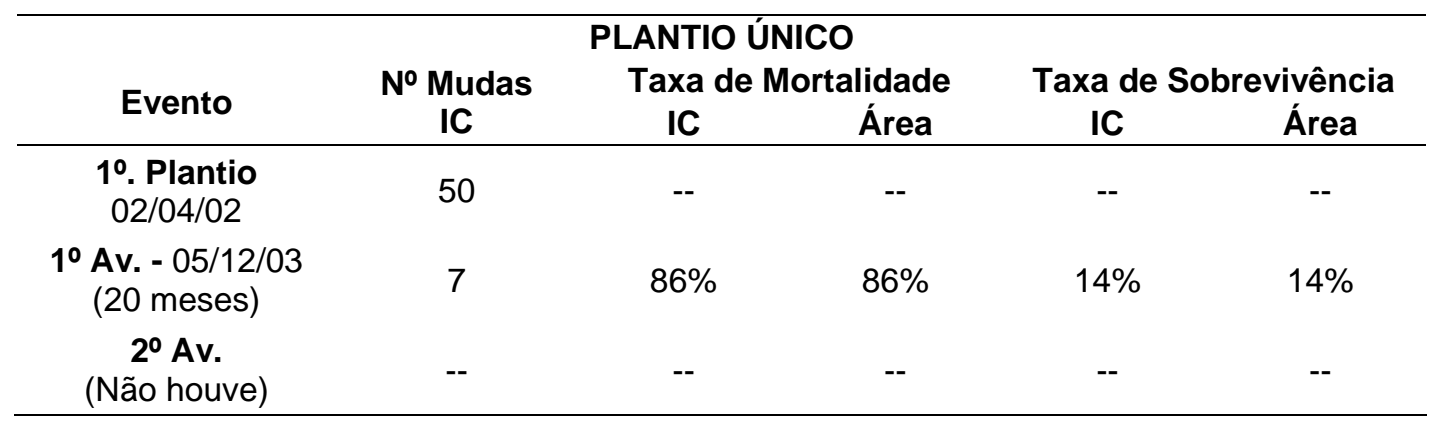

Das Tabelas apresentadas pode ser reconstituído o histórico do processo de plantio e avaliadas as possíveis causas de mortalidade, o que é apresentado a seguir para cada área estudada.

\section{Canal da Cosipa}

Para o Canal da Cosipa foram realizados três plantios pois no primeiro, após pequeno período de tempo (3 meses), foi constatada alta mortalidade. Assim, como havia propágulos reservados para possível replantio, fez-se o segundo plantio juntamente com a avaliação final do primeiro. A causa da mortalidade no primeiro plantio não pôde ser definida, porém uma hipótese é o efeito das marolas pois a parte frontal da parcela de plantio (mais próxima do canal) foi mais afetada, no entanto, houve perdas também no trecho posterior. A taxa de mortalidade foi maior para as mudas trazidas da llha do Cardoso (90\%) do que para as mudas de propágulos do próprio local (80\%).

O segundo plantio foi então realizado em um trecho do bosque que também apresentava uma densidade mais baixa de indivíduos, porém um pouco mais recuado em relação ao canal e em um trecho onde havia uma árvore caída formando uma pequena barreira que atenuaria efeitos muito severos das marolas. Na primeira avaliação (após 7 meses) a mortalidade foi de $100 \%$ para mudas da Ilha do Cardoso e de $72 \%$ para mudas do próprio Canal. Como não 
restaram mudas trazidas da área testemunha para a avaliação, foi viabilizado o terceiro plantio, repetindo-se a coleta de propágulos pois a quantidade inicial reservada não seria suficiente para realização do terceiro plantio.

A parcela do terceiro plantio foi implantada além da faixa do bosque, em uma clareira, visando distanciamento do efeito das marolas e avaliação da regeneração a pleno sol. Na primeira avaliação, após 6 meses, a situação se inverteu, tendo a mortalidade sido maior para as mudas do local (90\%) do que as mudas da área testemunha (78\%). No entanto, na segunda avaliação (após 7 meses da primeira), novamente se confirma a tendência de alta mortalidade na área, com redução especialmente das mudas da Ilha do Cardoso (mortalidade de 98\%), seguida das mudas do local (mortalidade de 94\%).

Verifica-se que no geral houve uma maior mortalidade para os propágulos da Ilha do Cardoso, porém os remanescentes se desenvolvem melhor do que àqueles da própria área, quando plantados à pleno sol.

\section{Rio Cascalho}

Para o Rio Cascalho foram realizados dois plantios, pois na primeira avaliação (após 9 meses), foi constatada alta mortalidade. Assim, fez-se o segundo plantio com propágulos da segunda coleta já que não havia propágulos armazenados em quantidade suficiente para o replantio. O segundo plantio foi feito juntamente com a avaliação final do primeiro. A causa da mortalidade no primeiro plantio não pôde ser definida, porém uma hipótese é que o local definido estaria submerso por período de tempo muito prolongado, comprometendo as mudas; uma outra causa poderia ser o aparecimento de nódulos de barro impregnando os propágulos e possivelmente dificultando a respiração (não se tem conhecimento do motivo da formação de tais nódulos, mas pode estar associado ao tipo de sedimento no solo do local, muito argiloso, com floculação induzida possivelmente por algum fator físico ou químico associados ao solo e hidrodinâmica). A taxa de mortalidade foi maior para as 
mudas trazidas da Ilha do Cardoso (98\%) do que para as mudas de propágulos do próprio local (94\%), o que totaliza, considerando conjuntamente as duas origens, $92 \%$ de mortalidade.

O segundo plantio foi então realizado em um trecho do bosque na margem oposta do Rio Cascalho, em posição um pouco mais recuada da margem e paralelamente ao rio, aproveitando uma situação de microrelevo pouco mais alto, onde a água chegava mas permanecia por menor período de tempo. Na primeira avaliação (após 6 meses) a mortalidade foi de 58\% para mudas da Ilha do Cardoso e de 50\% para mudas do próprio local. Na segunda avaliação (após 8 meses da primeira), a mortalidade continuou maior para as mudas da área testemunha (84\%) do que as mudas da própria área (70\%).

Verifica-se que a mortalidade para os propágulos da Ilha do Cardoso é sempre um pouco maior do que a dos propágulos da própria área.

\section{Rio Mariana}

Para o Rio Mariana foram realizados dois plantios, pois na primeira avaliação (após 10 meses) foi constatada 100\% de mortalidade na área. Assim, fez-se o segundo plantio com propágulos da segunda coleta já que não havia propágulos armazenados em quantidade suficiente para o replantio. A causa da mortalidade no primeiro plantio não pôde ser definida, porém uma hipótese é que a correnteza tenha arrastado as mudas, pois estas desapareceram, mas boa parte das estacas permaneceram.

O segundo plantio foi então realizado em um trecho do bosque, na mesma distância da margem, porém aproveitando uma situação de microrelevo pouco mais alto, onde a água chegava com menor velocidade e, portanto, com menor força de arraste. Neste local não havia a gramínea Espartina recobrindo o solo como na primeira área (apesar de que se considerava, no caso do primeiro plantio, que a Espartina atuava dando melhor fixação ao propágulo e 
minimizando a correnteza), de forma a tentar uma condição diferente da anterior. Na primeira avaliação do segundo plantio (após 6 meses) a mortalidade se repetiu em $100 \%$, com perda total das mudas e permanência de boa parte das estacas. A causa desta mortalidade generalizada foi novamente uma incógnita, não tendo sido definida.

Verifica-se que houve uma similaridade de mortalidade entre os propágulos desta área e da Ilha do Cardoso, mas como esta mortalidade foi total, a afirmação fica comprometida.

Ilha do Cardoso

Para a Ilha do Cardoso foi realizado apenas um plantio de 50 propágulos e a avaliação única de tal plantio deu-se após 20 meses, quando foi verificada a mortalidade de $86 \%$. Neste local havia mudas sem estacas, estacas sem mudas e ambas presentes ou ausente e a mortalidade não seguiu um padrão espacial. A causa desta mortalidade não pôde ser identificada, mas uma hipótese é o arrastamento pelas águas das marés, uma vez que esta área foi a que esteve mais tempo sob tais condições. Dentre as áreas de plantio esta foi a mais densa em relação à presença de árvores adultas, porém as mudas da regeneração natural se apresentavam mais distribuídas e foi mais freqüente mudas com altura superior a 1,50m.

\section{Para as quatro áreas}

As parcelas de plantio foram implantadas de forma a possibilitar a avaliação de várias condicionantes ambientais, tal como o afastamento da muda em relação ao curso d’água (posição perpendicular ou paralela ao rio e variação da distância da parcela em relação ao rio), efeito da luminosidade (parte da parcela sob insolação/parte sob mata ou integralmente sombreada ou 
integralmente a pleno sol). No entanto, a mortalidade foi generalizada e sem um padrão espacial definido que possa ser correlacionado à possível causa.

Sobre as possíveis causas da mortalidade, sem definição precisa, temse a acrescentar que se descartou causas antrópicas (como arrancamento) pois as áreas não tinham acesso muito facilitado ou atrativos, somente as estacas (que poderia ser o único atrativo) em geral permaneceram na área, inclusive algumas mais próximas ao rio. A predação também seria improvável pois não foram encontrados vestígios de propágulos predados (mesmo na área do Rio Mariana onde a quantidade de caranguejos era extremamente grande). Por fim, o arraste pelas correntezas das marés também não pode ser tomado como definitivo já que em geral as estacas (fincadas em profundidade similar ao comprimento do propágulo) permaneceram em quantidade razoável em parte ou em toda área de plantio e não havia um padrão espacial de arrancamento que pudesse ser associado às marés.

É interessante notar que em todas as áreas havia ocorrência de regeneração natural, com mudas e propágulos no interior ou adjacências das parcelas ou mesmo distribuídos pela área de amostragem, conforme destacado nas fotografias apresentadas no início do presente item. Esta regeneração variava entre as áreas com maior ou menor intensidade, porém sempre havia mudas, que por vezes se desenvolviam ao lado de uma muda plantada, que acabava por morrer ao longo do tempo.

Diversos autores (vide revisão bibliográfica) abordam as taxas de sobrevivência / mortalidade em plantios em Manguezais, o que estaria em geral relacionado à técnica de plantio e/ou interferências das condições ambientais. Bohorquez e Prada (1986) obtiveram sobrevivência de 34,8\% para transplante de plântulas; Sekar et al. (1989) citam estudos com sobrevivência de 9,35\% após 4 meses do plantio; Abraão (1998) descreve 100\% de mortalidade após 100 meses do plantio de mudas transplantadas de viveiro; Menezes et al (1994) destacam plantio direto de propágulos em Cubatão com 0\% de sobrevivência; 
Davis (1940) cita mortalidade de até 100\% após 4 meses; Paludo e Klonowski (1999) apresentam taxa de sobrevivência de 7\% após 2 anos do plantio (referese à $R$. mangle, L. racemosa e A. schaweriana). Sobre as causas da mortalidade são citadas: predação por caranguejos e pouca umidade (Paludo e Klonowski (1999), ausência de luz (Davis, 1940), quantidade e qualidade da água e tempo de encharcamento (Field, 1998); posicionamento da muda/ exposição à maré e competição (Moscatelli e Almeida, 1994), entre outros. Destes trabalhos nota-se uma grande variação nas taxas, porém em geral a mortalidade é alta, o que corroboram as avaliações deste trabalho.

Os dados obtidos indicam uma tendência geral de aumento da mortalidade ao longo do tempo. Assim, considerando a mortalidade total (sem diferenciação entre a origem dos propágulos), tem-se:

- Rio Mariana - maior mortalidade $(10$ meses $=100 \%$ e 6 meses $=100 \%)$.

- Canal da Cosipa - segunda maior mortalidade (3 meses $=85 \%, 7$ meses $=72 \%$ e 13 meses $=96 \%)$.

- Rio Cascalho - terceira maior mortalidade $(9$ meses $=92 \%, 6$ meses $=$ $54 \%$ e 14 meses $=77 \%$ ).

- Ilha do Cardoso - a melhor área com a menor mortalidade comparativa (20 meses $=86 \%)$. 


\subsection{Análise química do solo}

De acordo com Silva (2005), os dados avaliados para o solo das áreas também estudadas no presente trabalho, indicaram condições fisico-químicas com ampla variação no conteúdo de matéria orgânica, pH próximo à neutralidade e condições de oxidação-redução dominantemente anóxicas.

Adicionalmente, as Tabelas 30 e 31 apresentam os teores analisados dos metais traço em comparação aos valores de referência, alerta e intervenção estipulados pela CETESB (2001b) ${ }^{13}$.

${ }^{13}$ Conforme CETESB, estes indicam:

Valor de referência -indica o nível de qualidade para um solo considerado limpo.

Alerta - indica a alteração da qualidade natural dos solos (quando excedido a área será declarada poluída).

Intervenção - indica a existência de contaminação do solo (quando excedido a área será declarada contaminada, pois existe risco potencial de efeito deletério sobre a saúde humana). Este pode ser do tipo Intervenção residencial (mais severo) ou intervenção industrial. 
Tabela 30. Teores de metais nos solos dos Manguezais do Canal da COSIPA, Rio Cascalho e Rio Mariana

\begin{tabular}{|c|c|c|c|c|c|c|c|c|c|c|c|c|}
\hline \multirow{2}{*}{ Áreas } & \multirow{2}{*}{ Perfis } & \multirow{2}{*}{ Profundidade (cm) } & \multicolumn{10}{|c|}{ Elementos Químicos Analisados (mg.kg ${ }^{-1}$ ) } \\
\hline & & & $\mathbf{V}$ & $\mathrm{Cr}$ & Co & $\mathrm{Ni}$ & Cu & Zn & As & Ва & $\mathbf{P b}$ & Mo \\
\hline \multirow{7}{*}{ 通 } & \multirow{7}{*}{ P1 } & 0,5 & 48,60 & 73,70 & 6,70 & 16,40 & 10,10 & 48,54 & 0,00 & 697,00 & 17,40 & 5,23 \\
\hline & & 1,5 & 51,10 & 157,20 & 6,50 & 17,10 & 9,85 & 46,20 & 0,00 & 706,00 & 16,50 & 5,47 \\
\hline & & 3,5 & 44,70 & 124,00 & 6,50 & 17,00 & 8,45 & 42,50 & 0,00 & 639,00 & 17,80 & 6,57 \\
\hline & & 4,5 & 35,40 & 50,50 & 5,50 & 13,00 & 4,87 & 32,60 & 0,00 & 608,00 & 13,10 & 7,78 \\
\hline & & 7,5 & 37,00 & 64,80 & 6,00 & 13,60 & 5,58 & 37,10 & 0,00 & 662,00 & 13,40 & 6,66 \\
\hline & & 33,5 & 37,30 & 64,50 & 5,90 & 13,90 & 3,91 & 32,40 & 14,00 & 620,00 & 12,00 & 8,52 \\
\hline & & 70,0 & 77,30 & 84,80 & 10,00 & 25,30 & 16,70 & 66,38 & 13,00 & 703,00 & 15,70 & 2,94 \\
\hline \multirow{7}{*}{ 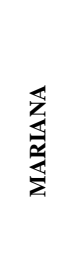 } & \multirow{7}{*}{ P1 } & 0,5 & 21,00 & 68,90 & 4,90 & 9,75 & 7,39 & 41,50 & 0,00 & 0,00 & 10,70 & 10,20 \\
\hline & & 1,5 & 33,60 & 40,00 & 5,40 & 10,80 & 5,26 & 45,80 & 0,00 & 0,00 & 9,49 & 10,50 \\
\hline & & 7,5 & 34,80 & 37,00 & 6,10 & 12,60 & 3,91 & 43,90 & 16,00 & 0,00 & 14,80 & 25,79 \\
\hline & & 12,5 & - & 62,09 & - & 11,27 & 3,37 & 21,70 & 20,24 & - & 4,88 & - \\
\hline & & 22,5 & 81,00 & 61,10 & 7,40 & 20,40 & 9,43 & 59,13 & 0,00 & 256,00 & 20,60 & 35,75 \\
\hline & & 32,5 & - & 92,75 & - & 17,56 & 7,74 & 70,25 & 16,62 & - & 10,11 & - \\
\hline & & 55,0 & 93,60 & 70,10 & 9,50 & 23,20 & 12,00 & 71,40 & 0,00 & 373,00 & 23,60 & 32,17 \\
\hline \multirow{21}{*}{$\begin{array}{l}\overleftarrow{\Xi} \\
\text { 范 } \\
0\end{array}$} & \multirow{6}{*}{ P1 } & 0,5 & 48,90 & 126,40 & 7,50 & 17,60 & 6,61 & 65,57 & 0,00 & 619,00 & 21,60 & 2,03 \\
\hline & & 1,5 & 44,50 & 71,10 & 7,00 & 16,50 & 6,14 & 63,41 & 0,00 & 596,00 & 18,10 & 3,63 \\
\hline & & 3,5 & 49,30 & 131,50 & 7,20 & 17,30 & 6,39 & 64,82 & 13,00 & 636,00 & 18,70 & 2,65 \\
\hline & & 7,5 & 41,50 & 60,90 & 7,10 & 15,50 & 6,01 & 60,55 & 0,00 & 555,00 & 18,20 & 2,62 \\
\hline & & 17,5 & 72,00 & 83,20 & 9,10 & 20,10 & 9,84 & 69,22 & 0,00 & 572,00 & 22,60 & 4,02 \\
\hline & & 50,0 & 116,00 & 91,40 & 14,00 & 33,10 & 22,60 & 105,00 & 15,00 & 555,00 & 37,00 & 2,54 \\
\hline & \multirow{7}{*}{ P2 } & 0,5 & - & 95,14 & - & 22,52 & 12,38 & 87,87 & 3,52 & - & 21,49 & - \\
\hline & & 3,5 & - & 75,82 & - & 20,26 & 14,95 & 105,18 & 7,65 & - & 22,14 & - \\
\hline & & 7,5 & - & 79,76 & - & 29,11 & 19,93 & 144,70 & 10,46 & - & 31,45 & - \\
\hline & & 12,5 & - & 77,85 & - & 28,97 & 20,53 & 174,95 & 11,22 & - & 38,34 & - \\
\hline & & 22,5 & - & 93,75 & - & 22,02 & 16,86 & 112,09 & 3,93 & - & 24,83 & - \\
\hline & & 32,5 & - & 116,31 & - & 31,66 & 14,46 & 89,88 & 11,39 & - & 21,99 & - \\
\hline & & 70,0 & - & 110,14 & - & 30,69 & 19,34 & 187,13 & 13,73 & - & 47,81 & - \\
\hline & \multirow{8}{*}{ P3 } & 0,5 & - & 44,57 & - & 17,10 & 5,13 & 42,58 & 3,78 & - & 11,88 & - \\
\hline & & 3,5 & - & 57,46 & - & 20,98 & 5,48 & 55,32 & 6,34 & - & 14,11 & - \\
\hline & & 7,5 & - & 65,66 & - & 18,55 & 9,90 & 53,86 & 5,16 & - & 14,62 & - \\
\hline & & 17,5 & - & 37,15 & - & 15,60 & 7,92 & 51,46 & 4,84 & - & 13,55 & - \\
\hline & & 22,5 & - & 26,76 & - & 15,74 & 6,20 & 46,60 & 4,48 & - & 13,19 & - \\
\hline & & 32,5 & - & 58,86 & - & 19,13 & 7,89 & 47,79 & 5,42 & - & 9,42 & - \\
\hline & & 55,0 & - & 35,60 & - & 10,66 & 10,31 & 51,00 & 6,38 & - & 12,27 & - \\
\hline & & 80,0 & - & 73,53 & - & 19,20 & 16,14 & 83,67 & 14,87 & - & 18,12 & - \\
\hline \multirow{4}{*}{\multicolumn{2}{|c|}{$\begin{array}{l}\text { Valores orientadores } \\
\text { para a qualidade dos } \\
\text { solos (mg.Kg } \mathbf{K g}^{-1} \text { ) no } \\
\text { Estado de São Paulo } \\
\text { (CETESB, 2001) }\end{array}$}} & Referência & 275 & 40 & 13 & 13 & 35 & 60 & 3,50 & 75 & 17 & $<25$ \\
\hline & & Alerta & $\mathrm{x}$ & 75 & 25 & 30 & 60 & 300 & 15 & 150 & 100 & 30 \\
\hline & & Intervenção: & $\mathrm{x}$ & $700^{*}$ & $80 *$ & $200^{*}$ & $500^{*}$ & $1000 *$ & $50 *$ & $400^{*}$ & $350^{*}$ & $100^{*}$ \\
\hline & & $\begin{array}{l}\text { Residencial* e } \\
\text { Industrial** }\end{array}$ & $\mathrm{x}$ & $1000^{* *}$ & $100^{*}$ & $300 * *$ & $700 * *$ & $1500^{* *}$ & $100^{* *}$ & $700^{* *}$ & $1200 * *$ & $120^{* *}$ \\
\hline
\end{tabular}

Fonte: Silva (2005). 
Tabela 31. Teores de metais em solos de Manguezais da Ilha do Cardoso

\begin{tabular}{|c|c|c|c|c|c|c|c|c|c|c|c|c|}
\hline \multirow{2}{*}{ Áreas } & \multirow{2}{*}{ Perfis } & \multirow{2}{*}{$\begin{array}{l}\text { Profundidade } \\
\text { (cm) }\end{array}$} & \multicolumn{10}{|c|}{ Elementos Químicos Analisados (mg.kg ${ }^{-1}$ ) } \\
\hline & & & $\mathbf{V}$ & $\mathbf{C r}$ & Co & $\mathbf{N i}$ & $\mathrm{Cu}$ & Zn & As & Ba & $\mathbf{P b}$ & Mo \\
\hline \multirow{19}{*}{ 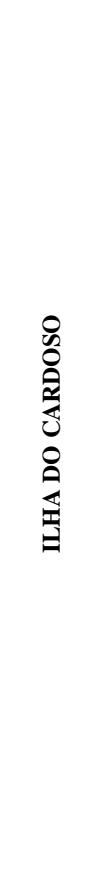 } & \multirow{4}{*}{ P1 } & 2,5 & 75,30 & 67,40 & 7,10 & 16,90 & 11,30 & 51,13 & 0,00 & 806,40 & 23,70 & 8,76 \\
\hline & & 7,5 & 58,40 & 58,70 & 6,60 & 13,20 & 5,69 & 48,02 & 0,00 & 852,40 & 19,50 & 13,10 \\
\hline & & 22,5 & 70,00 & 60,60 & 8,10 & 17,50 & 10,80 & 57,61 & 13,00 & 763,30 & 21,10 & 9,74 \\
\hline & & 70,0 & 71,20 & 70,40 & 8,00 & 17,20 & 10,80 & 58,89 & 14,00 & 768,60 & 18,30 & 9,43 \\
\hline & \multirow{5}{*}{ P2 } & 0,5 & 0,04 & 20,05 & - & - & - & 16,73 & 4,06 & - & 5,49 & - \\
\hline & & 3,5 & - & - & - & - & - & 20,31 & 1,76 & - & 8,10 & - \\
\hline & & 7,5 & - & - & - & - & - & 20,26 & 4,39 & - & 6,59 & - \\
\hline & & 22,5 & - & 25,80 & - & - & - & 14,37 & 3,31 & - & 5,51 & - \\
\hline & & 70,0 & - & - & - & - & - & 61,81 & 7,23 & - & 13,18 & - \\
\hline & \multirow{5}{*}{ P3 } & 0,5 & - & 71,08 & - & 12,91 & 11,69 & 40,41 & 11,44 & - & 11,20 & - \\
\hline & & 3,5 & - & 46,01 & - & 25,77 & 7,90 & 53,66 & 10,57 & - & 15,43 & - \\
\hline & & 7,5 & - & 64,87 & - & 14,44 & 5,58 & 53,23 & 10,89 & - & 17,20 & - \\
\hline & & 22,5 & - & 63,22 & - & 11,57 & 4,66 & 37,70 & 9,87 & - & 11,58 & - \\
\hline & & 60,0 & - & 74,68 & - & 20,61 & 7,64 & 55,48 & 8,81 & - & 18,43 & - \\
\hline & \multirow{5}{*}{ P4 } & 0,5 & 26,90 & 39,40 & 5,20 & 8,54 & 5,75 & 17,60 & 0,00 & 120,00 & 7,49 & 6,72 \\
\hline & & 1,5 & 27,10 & 34,80 & 5,30 & 7,81 & 1,77 & 16,80 & 0,00 & 93,10 & 9,69 & 7,43 \\
\hline & & 7,5 & 35,70 & 49,80 & 5,50 & 9,62 & 3,21 & 23,20 & 0,00 & 214,00 & 10,20 & 6,97 \\
\hline & & 22,5 & 26,00 & 35,20 & 5,20 & 8,35 & 1,69 & 16,40 & 0,00 & 79,10 & 5,92 & 8,26 \\
\hline & & 70,0 & 40,10 & 71,10 & 5,70 & 11,40 & 2,37 & 27,90 & 0,00 & 169,00 & 8,65 & 7,31 \\
\hline \multirow{4}{*}{\multicolumn{2}{|c|}{$\begin{array}{c}\text { Valores } \\
\text { orientadores para a } \\
\text { qualidade dos solos } \\
\left(\mathrm{mg.Kg}^{-1}\right) \text { no Estado } \\
\text { de São Paulo } \\
\text { (CETESB, 2001) }\end{array}$}} & Referência & 275,00 & 40 & 13 & 13 & 35 & 60 & 3,50 & 75 & 17 & $<25$ \\
\hline & & Alerta & $\mathrm{x}$ & 75 & 25 & 30 & 60 & 300 & 15 & 150 & 100 & 30 \\
\hline & & $\begin{array}{l}\text { Intervenção: } \\
\text { Residencial* e }\end{array}$ & $\mathrm{x}$ & $700 *$ & $80^{*}$ & $200 *$ & $500 *$ & $1000 *$ & $50^{*}$ & $400 *$ & $350 *$ & $100 *$ \\
\hline & & Industrial** & $\mathrm{x}$ & $1000 * *$ & $100 *$ & $300 * *$ & $700 * *$ & $1500^{* *}$ & $100 * *$ & $700 * *$ & $1200 * *$ & $120 * *$ \\
\hline
\end{tabular}

Obs.: O ponto que representa a situação específica da área de amostragem do presente estudo é o P4 - Rio Perequê.

Fonte: Silva (2005).

Assim, em relação ao conteúdo total dos metais, Silva (2005) concluiu sobre as condições do solo das áreas amostradas, o que segue:

Canal da Cosipa - solos poluídos por Cu e Cr e contaminado por Ba;

Rio Cascalho - solos poluídos por Cr e contaminados por Ba;

Rio Mariana - solos poluídos por Ba, Mo, As e Cr;

Ilha do Cardoso - não poluídos nem contaminados no Rio Perequê. 
Para facilitar as avaliações posteriores, foram calculadas médias das concentrações de metais nas diferentes profundidades do solo. Para o Canal da Cosipa a média incluiu os três perfis amostrados, para o Rio Cascalho e Rio Mariana o perfil único e para a Ilha do Cardoso, somente os dados do Perfil 4, que foi tomado no Rio Perequê, na mesma área de amostragem do presente estudo. Os resultados são apresentados na Tabela 32 a seguir.

Tabela 32. Teores médios de metais nos solos, padrões legais e avaliação do padrão para os Manguezais do Canal da Cosipa, Rio Cascalho, Rio Mariana e Ilha do Cardoso

\begin{tabular}{|c|c|c|c|c|c|c|c|c|}
\hline \multirow{2}{*}{ Área } & \multicolumn{8}{|c|}{ Metais (mg. $\mathrm{Kg}^{-1}$ ) } \\
\hline & Sn & $\mathrm{Hg}$ & $\mathrm{Zn}$ & $\mathrm{Cu}$ & $\mathrm{Ni}$ & $\mathrm{Cr}$ & $\mathrm{Pb}$ & Cd \\
\hline $\begin{array}{c}\text { Canal da } \\
\text { Cosipa }\end{array}$ & - & - & 83,94 & 11,67 & 21,06 & 76,80 & 21,50 & - \\
\hline $\begin{array}{c}\text { Rio } \\
\text { Cascalho }\end{array}$ & - & - & 43,25 & 8,49 & 16,61 & 88,50 & 15,13 & - \\
\hline $\begin{array}{c}\text { Rio } \\
\text { Mariana }\end{array}$ & - & - & 50,53 & 7,01 & 15,08 & 61,71 & 13,45 & - \\
\hline $\begin{array}{l}\text { Ilha do } \\
\text { Cardoso }\end{array}$ & - & - & 20,38 & 2,96 & 9,14 & 46,06 & 8,39 & - \\
\hline
\end{tabular}

Obs.:

Canal da Cosipa - considerou-se os perfis P1, P2 e P3 (profundidade entre 0,5 à $80,0 \mathrm{~cm})$

Rio Cascalho - considerou-se o perfil P1 (profundidade entre 0,5 à 70,0cm)

Rio Mariana considerou-se o perfil P1 (profundidade entre 0,5 à $55,0 \mathrm{~cm}$ )

Ilha do Cardoso considerou-se o perfil P4 (profundidade entre de 0,5 à 70,0m)

Fonte: Compilado e adaptado de Silva (2005). 


\subsection{Análise química de água e organismos}

Nas Tabelas 33 e 34 estão destacados os resultados obtidos pela CETESB para concentração de metais em amostras de água e organismos, incluindo o padrão e a avaliação comparativa com o padrão. Adicionalmente, para facilitar a posterior interpretação dos resultados, calculou-se a média das amostras. Foram extraídos desta fonte apenas os pontos de interesse para o presente estudo, ou seja:

- Ponto 05 - proximidades da área amostrada no Canal da Cosipa.

- Ponto 10 - proximidades da área amostrada no Rio Cascalho.

- Ponto 14 - proximidades da área amostrada no Rio Mariana.

Tabela 33. Concentração de metais em água na Baixada Santista

\begin{tabular}{|c|c|c|c|c|c|c|c|c|}
\hline \multirow{2}{*}{ Ponto } & \multicolumn{8}{|c|}{ Metais (mg/L) } \\
\hline & Sn & $\mathrm{Hg}$ & $\mathrm{Zn}$ & $\mathrm{Cu}$ & $\mathrm{Ni}$ & $\mathrm{Cr}$ & $\mathbf{P b}$ & Cd \\
\hline & \multicolumn{8}{|c|}{ Resultado } \\
\hline 5 & 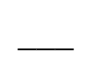 & $<0,0001$ & $<0,01$ & $<0,003$ & 0,05 & $<0,05$ & $<0,002$ & $<0,001$ \\
\hline Canal da & \multicolumn{8}{|c|}{ Avaliação com padrão } \\
\hline \multirow[t]{2}{*}{ Cosipa } & & $\begin{array}{l}\text { Inferior } \\
\text { limite }\end{array}$ & $\begin{array}{l}\text { Inferior } \\
\text { limite }\end{array}$ & $\begin{array}{l}\text { Inferior } \\
\text { limite }\end{array}$ & $\begin{array}{l}\text { Inferior } \\
\text { limite }\end{array}$ & $\begin{array}{l}\text { Inferior } \\
\text { limite }\end{array}$ & $\begin{array}{l}\text { Inferior } \\
\text { limite }\end{array}$ & $\begin{array}{l}\text { Inferior } \\
\text { limite }\end{array}$ \\
\hline & \multicolumn{8}{|c|}{ Resultado } \\
\hline 10 & 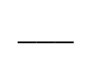 & $<0,0001$ & $<0,01$ & $<0,003$ & 0,06 & $<0,05$ & $<0,002$ & $<0,001$ \\
\hline Rio & \multicolumn{8}{|c|}{ Avaliação com padrão } \\
\hline \multirow[t]{2}{*}{ Cascalho } & 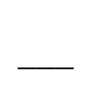 & $\begin{array}{l}\text { Inferior } \\
\text { limite }\end{array}$ & $\begin{array}{l}\text { Inferior } \\
\text { limite }\end{array}$ & $\begin{array}{l}\text { Inferior } \\
\text { limite }\end{array}$ & $\begin{array}{l}\text { Inferior } \\
\text { limite }\end{array}$ & $\begin{array}{c}\text { Inferior } \\
\text { limite }\end{array}$ & $\begin{array}{l}\text { Inferior } \\
\text { limite }\end{array}$ & $\begin{array}{l}\text { Inferior } \\
\text { limite }\end{array}$ \\
\hline & \multicolumn{8}{|c|}{ Resultado } \\
\hline 14 & - & $<0,0001$ & $<0,01$ & $<0,003$ & 0,05 & $<0,05$ & $<0,002$ & $<0,001$ \\
\hline Rio & \multicolumn{8}{|c|}{ Avaliação com padrão } \\
\hline Mariana & - & $\begin{array}{l}\text { Inferior } \\
\text { limite }\end{array}$ & $\begin{array}{l}\text { Inferior } \\
\text { limite }\end{array}$ & $\begin{array}{l}\text { Inferior } \\
\text { limite }\end{array}$ & $\begin{array}{l}\text { Inferior } \\
\text { limite }\end{array}$ & $\begin{array}{l}\text { Inferior } \\
\text { limite }\end{array}$ & $\begin{array}{l}\text { Inferior } \\
\text { limite }\end{array}$ & $\begin{array}{l}\text { Inferior } \\
\text { limite }\end{array}$ \\
\hline $\begin{array}{l}\text { Padrão } \\
\text { (mg/L)* }^{*}\end{array}$ & & 0,0001 & 0,17 & 0,05 & 0,1 & 0,05 & 0,01 & 0,005 \\
\hline
\end{tabular}


Tabela 34. Concentração de metais em organismos (peso úmido) na Baixada Santista

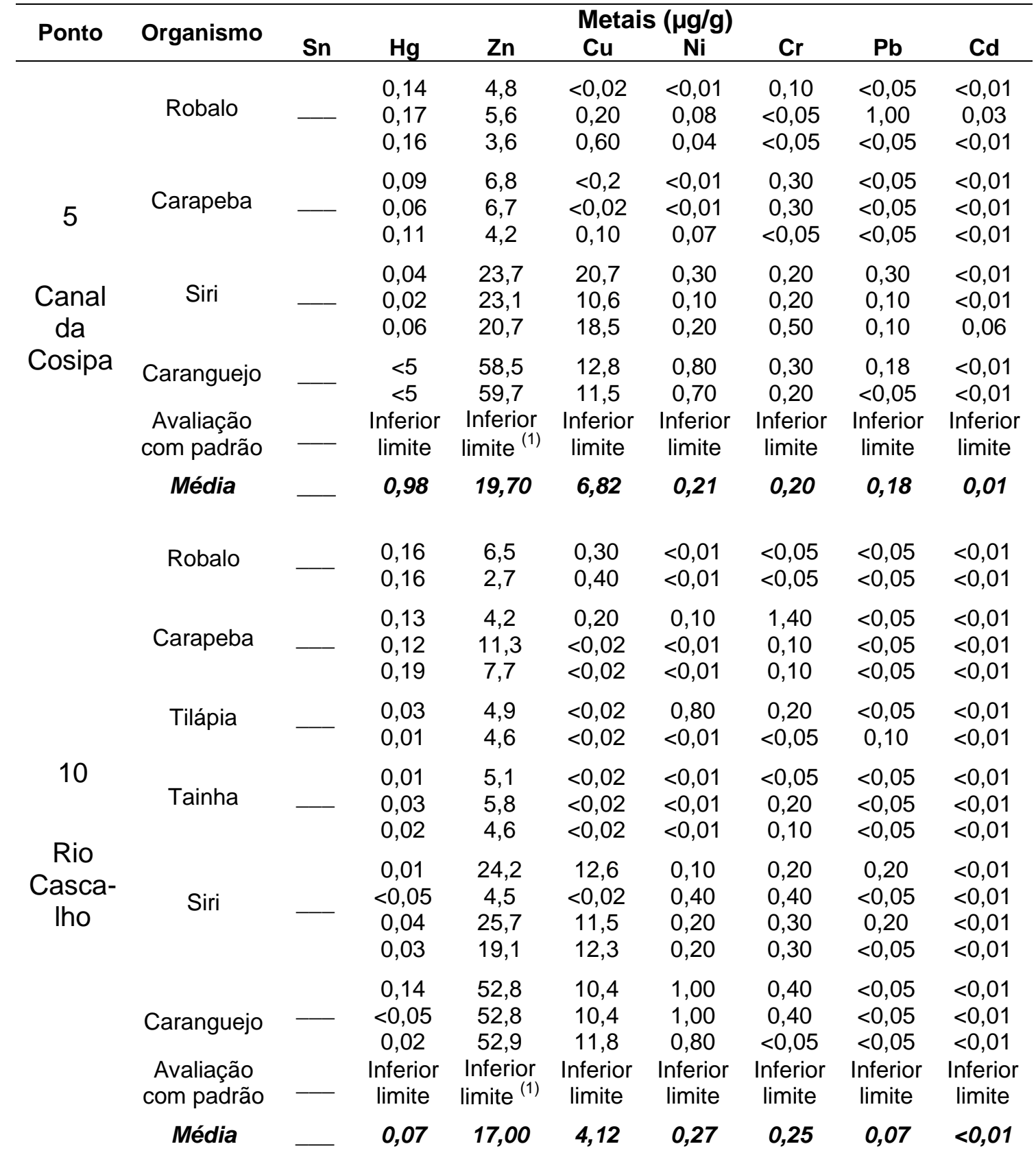




\begin{tabular}{|c|c|c|c|c|c|c|c|c|c|}
\hline \multirow{2}{*}{ Ponto } & \multirow{2}{*}{ Organismo } & \multicolumn{8}{|c|}{ Metais $(\mu \mathrm{g} / \mathrm{g})$} \\
\hline & & Sn & $\mathrm{Hg}$ & $Z n$ & $\mathrm{Cu}$ & $\mathrm{Ni}$ & $\mathrm{Cr}$ & $\mathbf{P b}$ & Cd \\
\hline \multirow{7}{*}{$\begin{array}{c}14 \\
\text { Rio } \\
\text { Maria- } \\
\text { na }\end{array}$} & Carapeba & 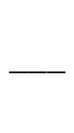 & $\begin{array}{l}0,10 \\
0,06 \\
0,10\end{array}$ & $\begin{array}{c}3,1 \\
56,1 \\
4,8\end{array}$ & $\begin{array}{c}0,10 \\
0,10 \\
<0,02\end{array}$ & $\begin{array}{c}<0,01 \\
0,08 \\
<0,01\end{array}$ & $\begin{array}{c}<0,05 \\
<0,05 \\
0,10\end{array}$ & $\begin{array}{l}<0,05 \\
<0,05 \\
<0,05\end{array}$ & $\begin{array}{l}<0,01 \\
<0,01 \\
<0,01\end{array}$ \\
\hline & Tainha & — & $\begin{array}{l}0,01 \\
0,01 \\
0,00\end{array}$ & $\begin{array}{c}7,0 \\
4,9 \\
23,4\end{array}$ & $\begin{array}{l}<0,02 \\
<0,02 \\
<0,02\end{array}$ & $\begin{array}{c}0,10 \\
<0,01 \\
<0,01\end{array}$ & $\begin{array}{c}0,20 \\
0,20 \\
<0,05\end{array}$ & $\begin{array}{l}<0,05 \\
<0,05 \\
<0,05\end{array}$ & $\begin{array}{l}<0,01 \\
<0,01 \\
<0,01\end{array}$ \\
\hline & Robalo & & $\begin{array}{c}0,16 \\
0,012 \\
0,02\end{array}$ & $\begin{array}{l}5,8 \\
4,5 \\
5,7\end{array}$ & $\begin{array}{l}<0,02 \\
<0,02 \\
<0,02\end{array}$ & $\begin{array}{l}<0,01 \\
<0,01 \\
<0,01\end{array}$ & $\begin{array}{l}0,50 \\
0,20 \\
0,20\end{array}$ & $\begin{array}{l}<0,05 \\
<0,05 \\
<0,05\end{array}$ & $\begin{array}{l}<0,01 \\
<0,01 \\
<0,01\end{array}$ \\
\hline & Siri & - & $\begin{array}{l}0,08 \\
0,03 \\
0,04\end{array}$ & $\begin{array}{l}35,6 \\
23,9 \\
21,8\end{array}$ & $\begin{array}{c}20,0 \\
12,5 \\
9,9\end{array}$ & $\begin{array}{l}0,07 \\
0,30 \\
0,20\end{array}$ & $\begin{array}{c}<0,05 \\
0,30 \\
0,10\end{array}$ & $\begin{array}{c}<0,05 \\
0,10 \\
<0,05\end{array}$ & $\begin{array}{l}<0,01 \\
<0,01 \\
<0,01\end{array}$ \\
\hline & Caranguejo & & $\begin{array}{l}0,00 \\
0,00\end{array}$ & $\begin{array}{l}57,8 \\
54,8 \\
548\end{array}$ & $\begin{array}{r}8,6 \\
9,0 \\
100\end{array}$ & $\begin{array}{l}0,20 \\
0,40 \\
0,50\end{array}$ & $\begin{array}{c}<0,05 \\
0,30\end{array}$ & $\begin{array}{l}0,19 \\
0,20 \\
0,20\end{array}$ & $\begin{array}{l}<0,01 \\
<0,01\end{array}$ \\
\hline & $\begin{array}{l}\text { Avaliação } \\
\text { com padrão }\end{array}$ & . & $\begin{array}{c}\text { Inferior } \\
\text { limite }\end{array}$ & $\begin{array}{l}\text { Inferior } \\
\text { limite }^{(1)}\end{array}$ & $\begin{array}{l}\text { Inferior } \\
\text { limite }\end{array}$ & $\begin{array}{l}\text { Inferior } \\
\text { limite }\end{array}$ & $\begin{array}{l}\text { Inferior } \\
\text { limite }\end{array}$ & $\begin{array}{l}\text { Inferior } \\
\text { limite }\end{array}$ & $\begin{array}{l}\text { Inferior } \\
\text { limite }\end{array}$ \\
\hline & Média & - & 0,05 & 24,24 & 4,68 & 0,17 & 0,18 & 0,08 & $<0,01$ \\
\hline & $\begin{array}{l}\text { rão } \\
\text { g)* }\end{array}$ & - & 0,50 & 50,00 & 30,00 & 5,00 & 11,00 & 2,00 & 1,00 \\
\hline
\end{tabular}

Notas:

* Padrão para Consumo humano no Brasil e na ausência de padrão nacional, complementação pelos padrões USEPA-U.S. Environmental Protection Agency e FDA-Food and Drug Administration.

(1) Para o Zn somente para caranguejo o resultado foi acima do limite.

Fonte: Compilado e adaptado de CETESB (2001a) 
Assim, as conclusões do trabalho da CETESB apontam o que segue:

- Para todos os metais avaliados os resultados da amostragem indicam valores abaixo do padrão legal.

- O Hg apresentou ampla distribuição em toda área estudada. Para organismos verificou-se redução nas concentrações ao longo do tempo (apesar de haver uma grande amplitude da variação dos resultados).

- Para o Zn as concentrações se mantiveram ao longo do tempo nos peixes, siris e mexilhões, mas elevou-se em ostras e caranguejos (há amostras superando os limites para consumo humano).

- O Cu apresentou uma aparente redução de seus níveis na água e nos peixes e, de forma oposta, concentrações maiores nos siris do Estuário de São Vicente.

- Para o Ni houve um aumento dos níveis nos sedimentos associado ao aumento das concentrações em siris no Rio Cubatão (amostras acima do limite recomendável para consumo humano).

- Para o Cr houve um aumento da concentração nos organismos aquáticos ao longo do tempo, requerendo uma melhor avaliação das possíveis fontes.

- O Pb, sob o aspecto regional, apresenta contaminação relacionada a fontes industriais de Cubatão e uma maior concentração na região da Cosipa, com elevados valores junto às principais fontes de poluição.

- Os valores de Cádmio sugerem ampla difusão na região, concentrando-se próximo às fontes, em especial no Estuário de São Vicente. Na fauna aquática, verifica-se uma redução da contaminação ao longo do tempo. 


\subsection{Análise química de material vegetal}

Resultados das análises químicas

Os resultados das análises da concentração de metais nos propágulos (antes do plantio), mudas (após término do período de avaliações do plantio) e folhas (coletadas das árvores matriz), assim como os valores do Limite de Detecção (LD) do método utilizado são apresentados nas Tabelas 35 a 38.

Os códigos constantes das referidas Tabelas são:

CC - Canal da Cosipa, RC - Rio Cascalho, RM - Rio Mariana,

IC - Ilha do Cardoso, RN - Regeneração Natural,

M1 e M2 - Matrizes 1 e 2, R - Repetição, LD - Limite de Detecção.

Médias representativas dos resultados das análises químicas

Além da apresentação dos resultados das análises, para facilitar a interpretação foi calculada uma média da concentração de cada metal. Entretanto, esta média não foi uma média simples, mas sim uma média denominada 'média representativa', para o cálculo da qual se adotou os seguintes critérios:

- Resultados muito discrepantes (superiores ao triplo do maior ou menor valor) foram desconsiderados no cálculo da média - estes estão destacados em negrito-itálico nas tabelas de resultados.

- Resultados LD, por se tratar de uma referência e não um valor puro, não foram tomados para o cálculo da média, porém, quando este resultado predominou entre as amostras, foi considerado como a média representativa.

- Quando se obteve apenas um resultado, a média foi considerada o próprio resultado. 
- Para os propágulos, a média representativa foi calculada para todos os resultados pois estes se referem aos lotes de propágulos coletados e respectivas repetições, para as quais não há interesse de individualização.

- Para as folhas, a média representativa foi calculada para todos os resultados pois a única distinção é a coleta em duas diferentes matrizes e suas repetições, não há interesse de individualização.

- Para as mudas, fez-se uma diferenciação no cálculo da média pois representam três casos distintos: muda de propágulo coletado e plantado na própria área, muda de propágulo coletado na llha do Cardoso e plantado na Baixada Santista e mudas da regeneração natural da área.

\section{Padrão de qualidade}

Seria interessante a comparação dos resultados obtidos com um critério de qualidade, à semelhança do que foi feito nas análises de solos. Porém, a legislação ambiental brasileira não dispõe de critérios de qualidade referentes à contaminação de plantas. Nesta linha existem apenas alguns padrões voltados a produtos agrícolas que visam normatizar a qualidade de alimentos para garantia da saúde humana, o que não se aplica ao caso em questão cujas plantas não se destinam ao consumo humano.

Assim, na falta de padrões específicos optou-se pela comparação das áreas entre si, para avaliação dos bosques de Manguezal. 
Tabela 35. Concentração de metais em material vegetal no Canal da Cosipa

\begin{tabular}{|c|c|c|c|c|c|c|c|c|}
\hline Código & $\begin{array}{c}\mathrm{Sn} \\
(\mathrm{mg} / \mathrm{g})\end{array}$ & $\begin{array}{c}\mathrm{Hg} \\
(\mathrm{mg} / \mathrm{g})\end{array}$ & $\begin{array}{c}\mathrm{Zn} \\
(\mu \mathrm{g} / \mathrm{g})\end{array}$ & $\begin{array}{c}\mathrm{Cu} \\
(\mu \mathrm{g} / \mathrm{g})\end{array}$ & $\begin{array}{c}\mathrm{Ni} \\
(\mu \mathrm{g} / \mathrm{g})\end{array}$ & $\begin{array}{c}\mathrm{Cr} \\
(\mu \mathrm{g} / \mathrm{g})\end{array}$ & $\begin{array}{c}\mathrm{Pb} \\
(\mu \mathrm{g} / \mathrm{g})\end{array}$ & $\begin{array}{c}\text { Cd } \\
\text { (ng/g) }\end{array}$ \\
\hline \multicolumn{9}{|c|}{ CANAL DA COSIPA - PROPÁGULOS } \\
\hline $1 / 1$ & LD & LD & 4,58 & 1,55 & 0,35 & 4,68 & 18,90 & 5,87 \\
\hline $1 / 2$ & LD & LD & 1,71 & 0,45 & 0,12 & LD & $L D$ & LD \\
\hline $2 / 1$ & LD & LD & 2,33 & 0,63 & 0,28 & 0,17 & 1,84 & LD \\
\hline $2 / 2$ & LD & LD & 2,19 & 0,60 & 0,25 & 0,07 & 0,41 & LD \\
\hline $3 / 1$ & LD & LD & 2,46 & 0,76 & 0,32 & LD & 0,86 & LD \\
\hline $3 / 2$ & LD & LD & 2,74 & 0,92 & 0,33 & LD & $L D$ & LD \\
\hline Média & $L D$ & $L D$ & 2,29 & 0,82 & 0,28 & $L D$ & 1,04 & $L D$ \\
\hline$L D$ & 0,71 & 0,023 & 0,06 & 0,11 & 0,01 & 0,07 & 0,01 & 1,00 \\
\hline \multicolumn{9}{|c|}{ CANAL DA COSIPA - MUDAS } \\
\hline CC IC 24 & LD & LD & 2,72 & 1,39 & 0,16 & 0,32 & 0,46 & LD \\
\hline CC IC 42 & LD & LD & 2,52 & 1,13 & LD & 0,69 & 1,10 & 27,90 \\
\hline CC IC 43 & LD & LD & 3,07 & 1,31 & 0,56 & 1,83 & 0,44 & LD \\
\hline CC CC 28 & LD & LD & 1,85 & 1,15 & 0,13 & 0,45 & 0,40 & LD \\
\hline CC RN 5 & LD & LD & 4,04 & 1,24 & $L D$ & 1,54 & 0,98 & 12,90 \\
\hline CC RN 6 & LD & LD & 2,25 & 0,57 & 0,52 & 1,22 & 0,37 & 7,08 \\
\hline CC RN 7 & LD & LD & 3,22 & 0,80 & 1,89 & 0,46 & 0,72 & 22,40 \\
\hline CC RN 8 & LD & LD & 1,67 & 0,77 & 0,19 & 0,33 & 0,27 & $L D$ \\
\hline CC RN 9 & LD & LD & 2,92 & 0,68 & 0,63 & 2,22 & 0,62 & 10,20 \\
\hline CC RN 10 & LD & LD & 2,12 & 0,59 & 0,33 & 0,66 & 0,44 & $L D$ \\
\hline Média IC & $L D$ & $L D$ & 2,77 & 1,28 & 0,36 & 0,95 & 0,67 & $L D$ \\
\hline Media CC & $L D$ & $L D$ & 1,85 & 1,15 & 0,13 & 0,45 & 0,40 & $L D$ \\
\hline Média RN & $L D$ & $L D$ & 2,70 & 0,78 & 0,71 & 1,07 & 0,57 & 13,16 \\
\hline Médiageral & $L D$ & $L D$ & 2,44 & 1,07 & 0,40 & 0,82 & 0,54 & 13,16 \\
\hline$L D$ & 0,71 & 0,023 & 0,06 & 0,11 & 0,01 & 0,07 & 0,01 & 1,00 \\
\hline \multicolumn{9}{|c|}{ CANAL DA COSIPA - FOLHAS } \\
\hline CC M1 R1 & LD & LD & 5,89 & 1,91 & 3,33 & 2,63 & 1,46 & LD \\
\hline CC M1 R2 & LD & LD & 4,63 & 1,02 & 1,25 & 1,24 & 1,38 & LD \\
\hline CC M1 R3 & LD & LD & 7,78 & 1,11 & 1,31 & 1,47 & 2,88 & 11,90 \\
\hline CC M1 R4 & LD & LD & 5,71 & 1,14 & 0,60 & 0,74 & 1,48 & LD \\
\hline CC M1 R5 & LD & LD & 5,34 & 1,00 & 0,69 & 0,76 & 3,06 & LD \\
\hline CC M2 R1 & LD & LD & 6,18 & 1,34 & 0,95 & 1,36 & 2,63 & 10,90 \\
\hline CC M2 R2 & LD & LD & 6,35 & 1,28 & 0,41 & 0,44 & 1,05 & LD \\
\hline CC M2 R3 & LD & LD & 4,36 & 1,00 & 0,45 & 0,78 & 1,10 & LD \\
\hline CC M2 R4 & LD & LD & 8,15 & 1,64 & 0,61 & 0,79 & 1,50 & LD \\
\hline CC M2 R5 & LD & LD & 4,45 & 0,89 & 0,67 & 1,22 & 1,39 & LD \\
\hline Média & $L D$ & $L D$ & 5,88 & 1,23 & 1,03 & 1,14 & 1,79 & $L D$ \\
\hline$\angle D$ & 0,71 & 0,023 & 0,06 & 0,11 & 0,01 & 0,07 & 0,01 & 1,00 \\
\hline
\end{tabular}


Tabela 36. Concentração de metais em material vegetal no Rio Cascalho

\begin{tabular}{|c|c|c|c|c|c|c|c|c|}
\hline $\begin{array}{l}\text { Coletal } \\
\text { repetição }\end{array}$ & $\begin{array}{c}\text { Sn } \\
(\mathrm{mg} / \mathrm{g})\end{array}$ & $\begin{array}{c}\mathrm{Hg} \\
(\mathrm{mg} / \mathrm{g})\end{array}$ & $\begin{array}{c}Z n \\
(\mu g / g)\end{array}$ & $\begin{array}{c}\mathrm{Cu} \\
(\mu \mathrm{g} / \mathrm{g})\end{array}$ & $\begin{array}{c}\mathrm{Ni} \\
(\mu \mathrm{g} / \mathrm{g})\end{array}$ & $\begin{array}{c}\mathrm{Cr} \\
(\mu \mathrm{g} / \mathrm{g})\end{array}$ & $\begin{array}{c}\mathrm{Pb} \\
(\mu \mathrm{g} / \mathrm{g})\end{array}$ & $\begin{array}{c}\text { Cd } \\
\text { (ng/g) }\end{array}$ \\
\hline \multicolumn{9}{|c|}{ RIO CASCALHO - PROPÁGULOS } \\
\hline $1 / 1$ & LD & LD & 1,91 & 1,12 & 0,33 & LD & 0,17 & LD \\
\hline $1 / 2$ & LD & LD & 2,46 & 1,75 & 0,48 & LD & 0,61 & LD \\
\hline $2 / 1$ & LD & LD & 3,64 & 1,95 & 1,23 & LD & 2,39 & LD \\
\hline $2 / 2$ & LD & LD & 4,01 & 2,22 & 1,46 & LD & 0,90 & LD \\
\hline $3 / 1$ & LD & LD & 2,03 & 1,02 & 0,42 & LD & 0,33 & LD \\
\hline $3 / 2$ & LD & LD & 2,53 & 1,57 & 0,44 & LD & 0,07 & LD \\
\hline Média & $\angle D$ & $\angle D$ & 2,76 & 1,61 & 0,73 & $L D$ & 0,75 & $\angle D$ \\
\hline$L D$ & 0,71 & 0,023 & 0,06 & 0,11 & 0,01 & 0,07 & 0,01 & 1,00 \\
\hline \multicolumn{9}{|c|}{ RIO CASCALHO - MUDAS } \\
\hline RC RC 9 & LD & LD & 3,55 & 3,16 & 0,31 & 0,67 & 0,59 & 10,60 \\
\hline RC RC 12 & LD & LD & 2,86 & 1,91 & 0,32 & 0,82 & 0,51 & 7,67 \\
\hline RC RC 29 & LD & LD & 3,59 & 2,60 & 0,57 & 2,56 & 1,03 & 9,60 \\
\hline RC RC 30 & LD & LD & 3,37 & 3,51 & 0,23 & 0,58 & 0,34 & 6,22 \\
\hline RC RC 49 & LD & LD & 1,95 & 1,31 & 0,12 & 0,21 & 0,29 & 44,00 \\
\hline RC IC 10 & LD & LD & 2,83 & 1,20 & 0,18 & 0,56 & 0,33 & 9,31 \\
\hline RC IC 25 & LD & LD & 2,24 & 1,18 & 0,14 & 0,28 & 0,59 & 4,15 \\
\hline RC IC 27 & LD & LD & 2,84 & 1,60 & 0,11 & 0,96 & 0,73 & 4,94 \\
\hline RC IC 33 & LD & LD & 2,49 & 1,25 & 0,14 & 0,48 & 0,38 & 6,27 \\
\hline RC IC 35 & LD & LD & 3,88 & 1,72 & 0,29 & 0,83 & 0,69 & 9,55 \\
\hline Média RC & $L D$ & $L D$ & 3,06 & 2,50 & 0,31 & 0,97 & 0,55 & 8,52 \\
\hline Média IC & $L D$ & $L D$ & 2,86 & 1,39 & 0,17 & 0,62 & 0,54 & 6,84 \\
\hline Médiageral & $L D$ & $\angle D$ & 2,96 & 1,94 & 0,24 & 0,79 & 0,54 & 7,68 \\
\hline$L D$ & 0,71 & 0,023 & 0,06 & 0,11 & 0,01 & 0,07 & 0,01 & 1,00 \\
\hline \multicolumn{9}{|c|}{ RIO CASCALHO - FOLHAS } \\
\hline RC M1 R1 & LD & LD & 3,91 & 1,57 & 0,44 & 0,26 & 0,61 & 4,28 \\
\hline $\mathrm{RC} M 1 \mathrm{R} 2$ & LD & LD & 3,10 & 1,22 & 0,30 & 0,31 & 0,43 & $L D$ \\
\hline RC M1 R3 & LD & LD & 4,05 & 20,30 & 0,36 & 0,18 & 0,54 & $L D$ \\
\hline RC M1 R4 & LD & LD & 5,61 & 1,43 & 0,34 & $L D$ & 0,62 & $L D$ \\
\hline RC M1 R5 & LD & LD & 5,20 & 1,72 & 0,30 & $L D$ & 0,36 & LD \\
\hline RC M2 R1 & LD & LD & 4,53 & 1,69 & 0,50 & $L D$ & 1,13 & 24,30 \\
\hline RC M2 R2 & LD & LD & 3,85 & 1,81 & 0,56 & 0,11 & 0,99 & 7,98 \\
\hline RC M2 R3 & LD & LD & 9,11 & 1,55 & 0,45 & 0,38 & 0,97 & 7,45 \\
\hline RC M2 R4 & LD & LD & 3,78 & 1,34 & 0,47 & 0,15 & 2,02 & 49,90 \\
\hline RC M2 R5 & LD & LD & 3,24 & 1,59 & 0,56 & 0,11 & 1,26 & 8,59 \\
\hline Média & $L D$ & $L D$ & 4,64 & 1,54 & 0,43 & 0,21 & 0,89 & 17,08 \\
\hline$L D$ & 0,71 & 0,023 & 0,06 & 0,11 & 0,01 & 0,07 & 0,01 & 1,00 \\
\hline
\end{tabular}


Tabela 37. Concentração de metais em material vegetal no Rio Mariana

\begin{tabular}{|c|c|c|c|c|c|c|c|c|}
\hline $\begin{array}{c}\text { Coletal } \\
\text { repetição }\end{array}$ & $\begin{array}{c}\mathrm{Sn} \\
(\mathrm{mg} / \mathrm{g})\end{array}$ & $\begin{array}{c}\mathrm{Hg} \\
(\mathrm{mg} / \mathrm{g})\end{array}$ & $\begin{array}{c}\mathrm{Zn} \\
(\mu \mathrm{g} / \mathrm{g})\end{array}$ & $\begin{array}{c}\mathrm{Cu} \\
(\mu \mathrm{g} / \mathrm{g})\end{array}$ & $\begin{array}{c}\mathrm{Ni} \\
(\mu \mathrm{g} / \mathrm{g})\end{array}$ & $\begin{array}{c}\mathrm{Cr} \\
(\mu \mathrm{g} / \mathrm{g})\end{array}$ & $\begin{array}{c}\mathrm{Pb} \\
(\mu \mathrm{g} / \mathrm{g})\end{array}$ & $\begin{array}{c}\text { Cd } \\
(\mathrm{ng} / \mathrm{g})\end{array}$ \\
\hline \multicolumn{9}{|c|}{ RIO MARIANA - PROPÁGULOS } \\
\hline $1 / 1$ & LD & LD & 1,59 & 1,77 & 0,33 & LD & 0,49 & LD \\
\hline $1 / 2$ & LD & LD & 1,29 & 0,54 & 0,22 & LD & $L D$ & LD \\
\hline $2 / 1$ & LD & LD & 1,31 & 0,10 & 0,16 & LD & $L D$ & LD \\
\hline $2 / 2$ & LD & LD & 1,71 & 0,56 & 0,23 & LD & 0,55 & LD \\
\hline $3 / 1$ & LD & LD & 2,19 & 0,48 & 0,31 & LD & $L D$ & LD \\
\hline $3 / 2$ & LD & LD & 1,44 & 0,27 & 0,33 & 0,13 & 0,87 & LD \\
\hline Média & $L D$ & $\angle D$ & 1,59 & 0,62 & 0,26 & $L D$ & 0,64 & $\angle D$ \\
\hline$\angle D$ & 0,71 & 0,023 & 0,06 & 0,11 & 0,01 & 0,07 & 0,01 & 1,00 \\
\hline \multicolumn{9}{|c|}{ RIO MARIANA - MUDAS } \\
\hline Código & $\begin{array}{c}\mathrm{Sn} \\
(\mathrm{mg} / \mathrm{g})\end{array}$ & $\begin{array}{c}\mathrm{Hg} \\
(\mathrm{mg} / \mathrm{g})\end{array}$ & $\begin{array}{c}\mathrm{Zn} \\
(\mu \mathrm{g} / \mathrm{g})\end{array}$ & $\begin{array}{c}\mathrm{Cu} \\
(\mu \mathrm{g} / \mathrm{g})\end{array}$ & $\underset{(\mu \mathrm{gi} / \mathrm{g})}{\mathrm{Ni}}$ & $\underset{(\mu \mathrm{g} / \mathrm{g})}{\mathrm{Cr}}$ & $\begin{array}{c}\mathrm{Pb} \\
(\mu \mathrm{g} / \mathrm{g})\end{array}$ & $\begin{array}{c}\mathrm{Cd} \\
(\mathrm{ng} / \mathrm{g})\end{array}$ \\
\hline RM RN 1 & LD & LD & 4,04 & 0,80 & LD & $L D$ & 0,54 & 15,50 \\
\hline RM RN 2 & LD & LD & 4,72 & 1,17 & LD & 0,39 & 0,93 & 22,40 \\
\hline RM RN 3 & LD & LD & 4,20 & 1,36 & LD & 0,48 & 0,96 & 33,80 \\
\hline RM RN 4 & LD & LD & 4,32 & 1,02 & 0,13 & 0,95 & 0,64 & 19,00 \\
\hline RM RN 5 & LD & LD & 3,88 & 1,02 & LD & 0,65 & 0,70 & 11,90 \\
\hline RM RN 6 & LD & LD & 2,65 & 0,89 & LD & 0,36 & 0,62 & 5,88 \\
\hline RM RN 7 & LD & LD & 3,87 & 0,97 & LD & 0,29 & 0,51 & 16,50 \\
\hline RM RN 8 & LD & LD & 4,45 & 1,16 & LD & 0,22 & 0,66 & 24,10 \\
\hline RM RN 9 & LD & LD & 3,68 & 1,04 & 0,72 & 3,30 & 1,20 & 12,10 \\
\hline RM RN 10 & LD & LD & 2,49 & 0,84 & LD & 0,24 & 0,77 & 9,17 \\
\hline Média & $L D$ & $L D$ & 3,83 & 1,03 & $\angle D$ & 0,76 & 0,75 & 17,04 \\
\hline$L D$ & 0,71 & 0,023 & 0,06 & 0,11 & 0,01 & 0,07 & 0,01 & 1,00 \\
\hline \multicolumn{9}{|c|}{ RIO MARIANA - FOLHAS } \\
\hline Código & $\begin{array}{c}\text { Sn } \\
(\mathrm{mg} / \mathrm{g})\end{array}$ & $\begin{array}{c}\mathrm{Hg} \\
(\mathrm{mg} / \mathrm{g})\end{array}$ & $\begin{array}{c}Z n \\
(\mu g / g)\end{array}$ & $\begin{array}{c}\mathrm{Cu} \\
(\mu \mathrm{g} / \mathrm{g})\end{array}$ & $\begin{array}{c}\mathrm{Ni} \\
(\mu \mathrm{g} / \mathrm{g})\end{array}$ & $\begin{array}{c}\mathrm{Cr} \\
(\mu \mathrm{g} / \mathrm{g})\end{array}$ & $\begin{array}{c}\mathrm{Pb} \\
(\mu \mathrm{g} / \mathrm{g})\end{array}$ & $\begin{array}{c}\text { Cd } \\
(\mathrm{ng} / \mathrm{g})\end{array}$ \\
\hline RC M1 R1 & LD & LD & 5,61 & 1,92 & 0,77 & 0,97 & 1,29 & LD \\
\hline RC M1 R2 & LD & LD & 4,20 & 0,94 & 0,31 & 0,52 & 0,61 & LD \\
\hline RC M1 R3 & LD & LD & 4,30 & 1,33 & 0,52 & 0,94 & 1,55 & LD \\
\hline RC M1 R4 & LD & LD & 6,63 & 1,72 & 0,41 & 0,51 & 0,46 & LD \\
\hline RC M1 R5 & LD & LD & 6,30 & 1,58 & 0,35 & 0,36 & 0,68 & LD \\
\hline RC M2 R1 & LD & LD & 4,05 & 1,61 & 0,50 & 0,47 & 0,42 & LD \\
\hline RC M2 R2 & LD & LD & 3,75 & 2,05 & 0,43 & 0,64 & 1,09 & LD \\
\hline RC M2 R3 & LD & LD & 3,82 & 1,75 & 0,24 & 0,32 & 0,38 & LD \\
\hline RC M2 R4 & LD & LD & 4,10 & 1,33 & 0,21 & 0,30 & 0,40 & LD \\
\hline RC M2 R5 & LD & LD & 4,90 & 2,23 & 0,25 & 0,12 & 0,98 & LD \\
\hline Média & $L D$ & $L D$ & 4,77 & 1,65 & 0,40 & 0,52 & 0,79 & $L D$ \\
\hline$\angle D$ & 0,71 & 0,023 & 0,06 & 0,11 & 0,01 & 0,07 & 0,01 & 1,00 \\
\hline
\end{tabular}


Tabela 38. Concentração de metais em material vegetal na Ilha do Cardoso

\begin{tabular}{|c|c|c|c|c|c|c|c|c|}
\hline $\begin{array}{c}\text { Coletal } \\
\text { repetição }\end{array}$ & $\begin{array}{c}\mathrm{Sn} \\
(\mathrm{mg} / \mathrm{g})\end{array}$ & $\begin{array}{c}\mathrm{Hg} \\
(\mathrm{mg} / \mathrm{g})\end{array}$ & $\begin{array}{c}\mathrm{Zn} \\
(\mu \mathrm{g} / \mathrm{g})\end{array}$ & $\begin{array}{c}\mathrm{Cu} \\
(\mu \mathrm{g} / \mathrm{g})\end{array}$ & $\begin{array}{c}\mathrm{Ni} \\
(\mu \mathrm{g} / \mathrm{g})\end{array}$ & $\begin{array}{c}\mathrm{Cr} \\
(\mu \mathrm{g} / \mathrm{g})\end{array}$ & $\begin{array}{c}\mathrm{Pb} \\
(\mu \mathrm{g} / \mathrm{g})\end{array}$ & $\begin{array}{c}\text { Cd } \\
\text { (ng/g) }\end{array}$ \\
\hline \multicolumn{9}{|c|}{ ILHA DO CARDOSO - PROPÁGULOS } \\
\hline $1 / 1$ & LD & LD & 2,70 & 3,65 & 0,23 & LD & 2,57 & LD \\
\hline $1 / 2$ & LD & LD & 1,82 & 2,83 & 0,23 & LD & $L D$ & LD \\
\hline $2 / 1$ & LD & LD & 3,45 & 5,00 & 0,43 & LD & 0,26 & LD \\
\hline $2 / 2$ & LD & LD & 1,90 & 3,03 & 0,39 & LD & 0,00 & LD \\
\hline $3 / 1$ & LD & LD & 3,50 & 7,24 & 0,42 & LD & 1,40 & LD \\
\hline $3 / 2$ & LD & LD & 1,39 & 2,40 & 0,31 & LD & 0,06 & LD \\
\hline Média & $L D$ & $L D$ & 2,46 & 4,03 & 0,34 & $L D$ & 0,86 & $L D$ \\
\hline$L D$ & 0,71 & 0,023 & 0,06 & 0,11 & 0,01 & 0,07 & 0,01 & 1,00 \\
\hline \multicolumn{9}{|c|}{ ILHA DO CARDOSO - MUDAS } \\
\hline IC IC 17 & LD & LD & LD & LD & LD & LD & LD & LD \\
\hline IC IC 22 & LD & LD & LD & LD & LD & LD & LD & LD \\
\hline IC IC 24 & LD & LD & LD & LD & LD & LD & LD & LD \\
\hline IC IC 25 & LD & LD & LD & LD & LD & LD & LD & LD \\
\hline IC IC 30 & LD & LD & LD & LD & LD & LD & LD & LD \\
\hline IC IC 35 & LD & LD & LD & LD & LD & LD & LD & LD \\
\hline IC IC 50 & LD & LD & LD & LD & LD & LD & LD & LD \\
\hline IC RN 1 & LD & LD & LD & LD & LD & LD & LD & LD \\
\hline IC RN 2 & LD & LD & LD & LD & LD & LD & LD & LD \\
\hline IC RN 3 & LD & LD & LD & LD & LD & LD & LD & LD \\
\hline Média IC & $\angle D$ & $L D$ & $L D$ & $L D$ & $L D$ & $L D$ & $L D$ & $L D$ \\
\hline Média RN & $\angle D$ & $L D$ & $L D$ & $L D$ & $L D$ & $L D$ & $L D$ & $L D$ \\
\hline Média geral & $L D$ & $L D$ & $\angle D$ & $L D$ & $L D$ & $L D$ & $L D$ & $L D$ \\
\hline$L D$ & 0,71 & 0,023 & 0,06 & 0,11 & 0,01 & 0,07 & 0,01 & 1,00 \\
\hline \multicolumn{9}{|c|}{ ILHA DO CARDOSO - FOLHAS } \\
\hline IC M1 R1 & LD & LD & LD & LD & LD & LD & LD & LD \\
\hline IC M1 R2 & LD & LD & LD & LD & LD & LD & LD & LD \\
\hline IC M1 R3 & LD & LD & LD & LD & LD & LD & LD & LD \\
\hline IC M1 R4 & LD & LD & LD & LD & LD & LD & LD & LD \\
\hline IC M1 R5 & LD & LD & LD & LD & LD & LD & LD & LD \\
\hline IC M2 R1 & LD & LD & LD & LD & LD & LD & LD & LD \\
\hline IC M2 R2 & LD & LD & LD & LD & LD & LD & LD & LD \\
\hline IC M2 R3 & LD & LD & LD & LD & LD & LD & LD & LD \\
\hline IC M2 R4 & LD & LD & LD & LD & LD & LD & LD & LD \\
\hline IC M2 R5 & LD & LD & LD & LD & LD & LD & LD & LD \\
\hline Média & $L D$ & $L D$ & $L D$ & $L D$ & $L D$ & $L D$ & $L D$ & $L D$ \\
\hline$L D$ & 0,71 & 0,023 & 0,06 & 0,11 & 0,01 & 0,07 & 0,01 & 1,00 \\
\hline
\end{tabular}




\section{Canal da Cosipa}

Para propágulos do Canal da Cosipa foram quatro os metais para os quais foi constatado concentrações acima do LD: Zn $(2,29 \mu \mathrm{g} / \mathrm{g})$, Cu $(0,82 \mu \mathrm{g} / \mathrm{g})$, $\mathrm{Ni}(0,28 \mu \mathrm{g} / \mathrm{g})$ e $\mathrm{Pb}(1,04 \mu \mathrm{g} / \mathrm{g})$.

Para mudas, a concentração de Zn $(2,77 \mu \mathrm{g} / \mathrm{g})$, Cu $(1,28 \mu \mathrm{g} / \mathrm{g})$ e Pb $(0,67 \mu \mathrm{g} / \mathrm{g})$ foi maior para aquelas originadas de propágulos da Ilha do Cardoso, porém com pouca diferença entre as demais origens. $\mathrm{Ni}(0,71 \mu \mathrm{g} / \mathrm{g})$ e $\mathrm{Cr}$ $(1,07 \mu \mathrm{g} / \mathrm{g})$ foram maiores para a regeneração natural. O Cd foi o metal cujos resultados apresentaram a maior discrepância entre as amostras e as médias, sendo a concentração maior nas mudas da regeneração natural $(13,16 \mathrm{ng} / \mathrm{g})$.

Para folhas foram cinco os metais para os quais foi constatado concentrações acima do LD: Zn $(5,88 \mu \mathrm{g} / \mathrm{g}), \mathrm{Cu}(1,23 \mu \mathrm{g} / \mathrm{g}), \mathrm{Ni}(1,03 \mu \mathrm{g} / \mathrm{g}), \mathrm{Cr}$ $(1,14 \mu \mathrm{g} / \mathrm{g})$ e $\mathrm{Pb}(1,79 \mu \mathrm{g} / \mathrm{g})$.

A relação de concentração nas partes da planta para os diferentes metais foi a seguinte:

$$
\begin{array}{ll}
\mathrm{Zn} \rightarrow \text { folha }>\text { muda }>\text { propágulo } & \mathrm{Cu} \rightarrow \text { folha }>\text { muda }>\text { propágulo } \\
\mathrm{Ni} \rightarrow \text { folha }>\text { muda }>\text { propágulo } & \mathrm{Cr} \rightarrow \text { folha }>\text { muda }>\text { propágulo } \\
\mathrm{Pb} \rightarrow \text { folha }>\text { propágulo }>\text { muda } & \mathrm{Cd} \rightarrow \text { muda }>\text { propágulo }=\text { folha }
\end{array}
$$

Em comparação com a área testemunha, o Canal da Cosipa apresenta:

- Folhas mais contaminadas no Canal da Cosipa, para todos os metais com exceção de Cd, Sn, Hg com concentração semelhante (LD).

- Mudas mais contaminadas no Canal da Cosipa, para todos os metais com exceção de Sn e Hg com concentração semelhante (LD).

- Propágulos, há maior contaminação na Ilha do Cardoso para Zn, Cu, $\mathrm{Ni}$ e $\mathrm{Pb}$; e semelhante situação para $\mathrm{Cr}$, Cd, Sn e Hg. 


\section{Rio Cascalho}

Para propágulos do Rio Cascalho foram quatro os metais para os quais foi constatado concentrações acima do LD: Zn $(2,76 \mu \mathrm{g} / \mathrm{g})$, Cu $(1,61 \mu \mathrm{g} / \mathrm{g})$, Ni $(0,73 \mu \mathrm{g} / \mathrm{g})$ e $\mathrm{Pb}(0,75 \mu \mathrm{g} / \mathrm{g})$.

Para mudas, a concentração de Zn $(3,06 \mu \mathrm{g} / \mathrm{g}), \mathrm{Cu}(2,50 \mu \mathrm{g} / \mathrm{g})$, Ni $(0,31 \mu \mathrm{g} / \mathrm{g}), \mathrm{Cr}(0,97 \mu \mathrm{g} / \mathrm{g}), \mathrm{Pb}(0,55 \mu \mathrm{g} / \mathrm{g})$ e $\mathrm{Cd}(8,52 \mathrm{ng} / \mathrm{g})$, foram todas maiores para mudas originadas e plantadas no Rio cascalho, porém com pouca diferença para as originadas da Ilha do Cardoso.

Para folhas foram seis os metais para os quais foi constatado

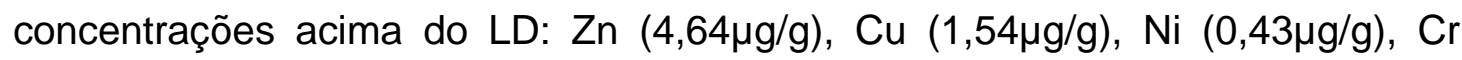
$(0,21 \mu \mathrm{g} / \mathrm{g}), \mathrm{Pb}(0,89 \mu \mathrm{g} / \mathrm{g})$ e $\mathrm{Cd}(17,08 \mathrm{ng} / \mathrm{g})$. As maiores discrepâncias entre os resultados das amostras foram constatadas novamente para este último.

A relação de concentração nas partes da planta para os diferentes metais foi a seguinte:

$$
\begin{array}{ll}
\mathrm{Zn} \rightarrow \text { folha }>\text { muda }>\text { propágulo } & \mathrm{Cu} \rightarrow \text { muda }>\text { propágulo }>\text { folha } \\
\mathrm{Ni} \rightarrow \text { propágulo }>\text { folh }>\text { muda } & \mathrm{Cr} \rightarrow \text { muda }>\text { folha }>\text { propágulo } \\
\mathrm{Pb} \rightarrow \text { folha }>\text { propágulo }>\text { muda } & \mathrm{Cd} \rightarrow \text { folha }>\text { muda }>\text { propágulo }
\end{array}
$$

Em comparação com a área testemunha, o Rio Cascalho apresenta:

- Folhas mais contaminadas no Rio Cascalho, para todos os metais com exceção de Sn e Hg com concentração semelhante (LD).

- Mudas mais contaminadas no Rio cascalho, para todos os metais com exceção de Sn e Hg para os quais a concentração se assemelha (LD).

- Propágulos - há maior concentração na Ilha do Cardoso para Cu e Pb; há maior concentração no Rio Cascalho para Zn e Ni e para Cr, Cd, Sn e Hg a concentração se assemelha (LD). 


\section{Rio Mariana}

Para propágulos do Rio Mariana foram quatro os metais para os quais foi constatado concentrações acima do LD: Zn $(1,59 \mu \mathrm{g} / \mathrm{g}) \mathrm{Cu}(0,62 \mu \mathrm{g} / \mathrm{g})$, Ni $(0,26 \mu \mathrm{g} / \mathrm{g})$ e $\mathrm{Pb}(0,64 \mu \mathrm{g} / \mathrm{g})$.

Para mudas, todas da regeneração natural, as concentrações

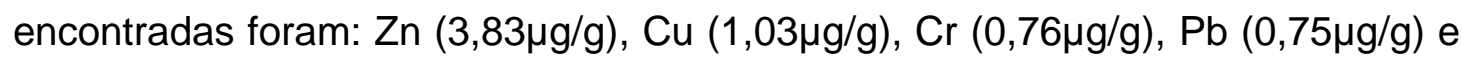
Cd $(17,04 \mathrm{ng} / \mathrm{g})$ foram maiores para a regeneração natural. O Cd foi o metal cujos resultados apresentaram a maior discrepância entre as amostras e as médias, sendo a concentração maior nas mudas da regeneração natural $(13,16 \mathrm{ng} / \mathrm{g})$.

Para folhas foram cinco os metais para os quais foi constatado concentrações acima do LD: Zn $(4,77 \mu \mathrm{g} / \mathrm{g}) \mathrm{Cu}(1,65 \mu \mathrm{g} / \mathrm{g})$, Ni $(0,40 \mu \mathrm{g} / \mathrm{g}), \mathrm{Cr}$ $(0,52 \mu \mathrm{g} / \mathrm{g})$ e $\mathrm{Pb}(0,79 \mu \mathrm{g} / \mathrm{g})$.

A relação de concentração nas partes da planta para os diferentes metais foi a seguinte:

$$
\begin{array}{ll}
\mathrm{Zn} \rightarrow \text { folha }>\text { muda }>\text { propágulo } & \mathrm{Cu} \rightarrow \text { folha }>\text { muda }>\text { propágulo } \\
\mathrm{Ni} \rightarrow \text { folha }>\text { propágulo }>\text { muda } & \mathrm{Cr} \rightarrow \text { muda }>\text { folha }>\text { propágulo } \\
\mathrm{Pb} \rightarrow \text { folha }>\text { muda }>\text { propágulo } & \mathrm{Cd} \rightarrow \text { muda }>\text { propágulo }=\text { folha }
\end{array}
$$

Em comparação com a área testemunha, o Canal da Cosipa apresenta:

- Folhas mais contaminadas no Rio Mariana, para todos os metais com exceção de Cd, Sn, Hg com concentração semelhante (LD).

- Mudas mais contaminadas no Rio Mariana, para todos os metais com exceção do Ni, Sn e Hg com concentração semelhante (LD).

- Propágulos, há maior contaminação na Ilha do Cardoso para Zn, Cu, Ni e Pb; e semelhante situação entre as áreas para Cr, Cd, Sn e Hg (LD). 
Ilha do Cardoso

Dos resultados tem-se que na Ilha do Cardoso as maiores

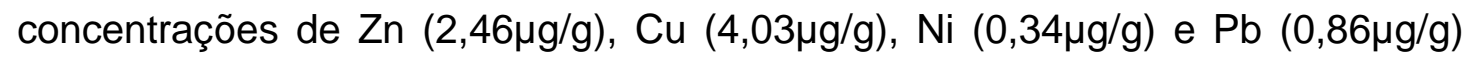
estão nos propágulos. Para o $\mathrm{Cr}, \mathrm{Cd}, \mathrm{Sn}$ e $\mathrm{Hg}$ os resultados se assemelham às mudas e folhas (LD).

A concentração nas partes da planta foi sempre igual para todos os metais, da seguinte forma: $\mathrm{Zn} ; \mathrm{Cu} ; \mathrm{Ni} ; \mathrm{Pb} \rightarrow$ propágulo $>$ folha $=$ muda.

\section{Para as quatro áreas}

As concentrações de Sn e Hg para propágulos, mudas e folhas nas quatro áreas sempre foram muito baixas, não tendo sido detectadas (LD) em nenhuma das áreas. Para $\mathrm{Cd}$, as quatro áreas apresentaram concentrações não detectáveis (LD) para propágulos.

Para facilitar a avaliação dos dados, a partir das tabelas anteriores elaborou-se uma tabela síntese (Tabela 39 da seqüência) calculando-se uma nova média das concentrações médias de metais nos três compartimentos vegetais (propágulo, mudas e folhas). Ressalta-se ainda que esta foi calculada utilizando a mesma metodologia de 'média representativa' adotada para as Tabelas 35 à 38 (resultados discrepantes, destacados em negrito-itálico, foram excluídos no cálculo da média). 
Tabela 39. Tabela síntese da concentração média de metais em material vegetal, considerando as médias para propágulos, mudas e folhas

\begin{tabular}{|c|c|c|c|c|c|c|c|c|}
\hline Material & $\begin{array}{c}\mathrm{Sn} \\
(\mathrm{mg} / \mathrm{g})\end{array}$ & $\begin{array}{c}\mathrm{Hg} \\
(\mathrm{mg} / \mathrm{g})\end{array}$ & $\begin{array}{c}\mathrm{Zn} \\
(\mu \mathrm{g} / \mathrm{g})\end{array}$ & $\begin{array}{c}\mathrm{Cu} \\
(\mu \mathrm{g} / \mathrm{g})\end{array}$ & $\begin{array}{c}\mathrm{Ni} \\
(\mu \mathrm{g} / \mathrm{g})\end{array}$ & $\begin{array}{c}\mathrm{Cr} \\
(\mu \mathrm{g} / \mathrm{g})\end{array}$ & $\begin{array}{c}\mathrm{Pb} \\
(\mu \mathrm{g} / \mathrm{g})\end{array}$ & $\begin{array}{c}\mathrm{Cd} \\
\text { (ng/g) }\end{array}$ \\
\hline \multicolumn{9}{|c|}{ Canal da Cosipa } \\
\hline Propágulo & LD & LD & 2,29 & 0,82 & 0,28 & $L D$ & 1,04 & LD \\
\hline Mudas & LD & LD & 2,44 & 1,07 & 0,40 & 0,82 & 0,54 & 13,16 \\
\hline Folhas & LD & LD & 5,88 & 1,23 & 1,03 & 1,14 & 1,79 & LD \\
\hline Média & LD & LD & 3,53 & 1,04 & 0,57 & 0,98 & 1,12 & LD \\
\hline \multicolumn{9}{|c|}{ Rio Cascalho } \\
\hline Propágulo & LD & LD & 2,76 & 1,61 & 0,73 & $L D$ & 0,75 & $L D$ \\
\hline Mudas & LD & LD & 2,96 & 1,94 & 0,24 & 0,79 & 0,54 & 7,68 \\
\hline Folhas & LD & LD & 4,64 & 1,54 & 0,43 & 0,21 & 0,89 & 17,08 \\
\hline Média & LD & LD & 3,45 & 1,69 & 0,46 & 0,50 & 0,72 & 12,38 \\
\hline \multicolumn{9}{|c|}{ Rio Mariana } \\
\hline Propágulo & LD & LD & 1,59 & 0,62 & 0,26 & $L D$ & 0,64 & LD \\
\hline Mudas & LD & LD & 3,83 & 1,03 & $L D$ & 0,76 & 0,75 & 17,04 \\
\hline Folhas & LD & LD & 4,77 & 1,65 & 0,40 & 0,52 & 0,79 & LD \\
\hline Média & LD & LD & 3,39 & 1,10 & 0,33 & 0,64 & 0,72 & LD \\
\hline \multicolumn{9}{|c|}{ Ilha do Cardoso } \\
\hline Propágulo & LD & LD & 2,46 & 4,03 & 0,34 & LD & 0,86 & LD \\
\hline Mudas & LD & LD & LD & LD & LD & LD & LD & LD \\
\hline Folhas & LD & LD & LD & LD & LD & LD & LD & LD \\
\hline Média & LD & LD & LD & LD & LD & LD & LD & LD \\
\hline
\end{tabular}

Resultados das análises estatísticas

Para viabilizar a avaliação comparativa entre as áreas com base na significância das diferenças foram feitas análises estatísticas para a concentração de metais nos propágulos, nas mudas e nas folhas, sendo os resultados apresentados nas Tabelas 40 a 42, a seguir. 
O número total de metais avaliados foram oito, porém as referidas tabelas não apresentam todos, pois para alguns os resultados nas análises químicas não permitiram a realização de análises estatísticas devido ao pequeno número de repetições, uma vez que não foram considerados os resultados LD - abaixo do limite de detecção.

Tabela 40. Avaliação da concentração de metais nos propágulos de R. mangle

\begin{tabular}{|c|c|c|c|c|c|c|}
\hline \multirow{2}{*}{ Parâmetro } & \multicolumn{3}{|c|}{$\begin{array}{l}\text { Metais nos propágulos / área } \\
\text { Análise de Variância }\end{array}$} & \multirow{2}{*}{\multicolumn{3}{|c|}{$\begin{array}{c}\text { Teste de Tukey } \\
\text { (5\% de probabilidade) }\end{array}$}} \\
\hline & Média & $\mathbf{F}$ & $\mathrm{Pr}>\mathrm{F}$ & & & \\
\hline Zinco $(\mu \mathrm{g} / \mathrm{g})$ & 2,37 & 2,60 & $0,0802 \mathrm{~ns}$ & $\begin{array}{c}\mathrm{RC} \\
\mathrm{CC} \\
\mathrm{RM} \\
\mathrm{IC}\end{array}$ & $\begin{array}{l}2,76 \\
2,67 \\
2,46 \\
1,59\end{array}$ & $\begin{array}{l}a \\
a \\
a \\
a\end{array}$ \\
\hline Cobre $(\mu \mathrm{g} / \mathrm{g})$ & 1,77 & 14,61 & 0,0001 ** & $\begin{array}{l}\text { RM } \\
\text { RC } \\
\text { CC } \\
\text { IC }\end{array}$ & $\begin{array}{l}4,02 \\
1,60 \\
0,82 \\
0,62\end{array}$ & $\begin{array}{l}a \\
b \\
b \\
b\end{array}$ \\
\hline Chumbo $(\mu \mathrm{g} / \mathrm{g})$ & 1,81 & 1,35 & 0,2985 ns & $\begin{array}{l}\text { CC } \\
\text { RM } \\
\text { RC } \\
\text { IC }\end{array}$ & $\begin{array}{l}5,50 \\
1,13 \\
0,74 \\
0,18\end{array}$ & $\begin{array}{l}\mathrm{a} \\
\mathrm{a} \\
\mathrm{a} \\
\mathrm{a}\end{array}$ \\
\hline Níquel ( $\mu \mathrm{g} / \mathrm{g})$ & 0,40 & 4,69 & 0,0123 * & $\begin{array}{l}\text { RC } \\
\text { RM } \\
\text { CC } \\
\text { IC }\end{array}$ & $\begin{array}{l}0,73 \\
0,35 \\
0,27 \\
0,24\end{array}$ & $\begin{array}{c}a \\
a b \\
b \\
b\end{array}$ \\
\hline
\end{tabular}

Legenda: Teste de Tukey para comparação de médias entre Áreas: IC - Ilha do Cardoso; CC - Canal da Cosipa; RM - Rio Marina; RC - Rio Cascalho. 
Tabela 41. Concentração de metais nas mudas (plantio e regeneração natural) de $R$. mangle

\begin{tabular}{|c|c|c|c|c|c|c|}
\hline \multirow{2}{*}{$\begin{array}{r}\text { Parâmetro } \\
\text { Zinco }(\mu \mathrm{g} / \mathrm{g})\end{array}$} & \multicolumn{3}{|c|}{$\begin{array}{l}\text { Metais nas mudas I área } \\
\text { Análise de Variância }\end{array}$} & \multicolumn{3}{|c|}{$\begin{array}{c}\text { Teste de Tukey } \\
\text { (5\% de probabilidade) }\end{array}$} \\
\hline & 3,14 & 7,93 & $0,0019 * *$ & $\begin{array}{l}\mathrm{RM} \\
\mathrm{RC} \\
\mathrm{CC}\end{array}$ & $\begin{array}{l}3,83 \\
2,96 \\
2,64\end{array}$ & $\begin{array}{l}a \\
b \\
b\end{array}$ \\
\hline Cobre $(\mu \mathrm{g} / \mathrm{g})$ & 1,31 & 10,58 & 0,0004 ** & $\begin{array}{l}\text { RC } \\
\text { RM } \\
\text { CC }\end{array}$ & $\begin{array}{l}1,94 \\
1,02 \\
0,96\end{array}$ & $\begin{array}{l}a \\
b \\
b\end{array}$ \\
\hline Chumbo $(\mu \mathrm{g} / \mathrm{g})$ & 0,63 & 2,09 & $0,1438 \mathrm{~ns}$ & $\begin{array}{l}\text { RM } \\
\text { CC } \\
\text { RC }\end{array}$ & $\begin{array}{l}0,75 \\
0,58 \\
0,54\end{array}$ & $\begin{array}{l}\mathrm{a} \\
\mathrm{a} \\
\mathrm{a}\end{array}$ \\
\hline Níquel $(\mu \mathrm{g} / \mathrm{g})$ & 0,38 & 1,38 & $0,2787 \mathrm{~ns}$ & $\begin{array}{l}\mathrm{CC} \\
\mathrm{RM} \\
\mathrm{RC}\end{array}$ & $\begin{array}{l}0,55 \\
0,42 \\
0,24\end{array}$ & $\begin{array}{l}\mathrm{a} \\
\mathrm{a} \\
\mathrm{a}\end{array}$ \\
\hline Cromo $(\mu \mathrm{g} / \mathrm{g})$ & 0,85 & 0,20 & 0,8195 ns & $\begin{array}{l}\mathrm{CC} \\
\mathrm{RC} \\
\mathrm{RM}\end{array}$ & $\begin{array}{l}0,97 \\
0,79 \\
0,76\end{array}$ & $\begin{array}{l}\mathrm{a} \\
\mathrm{a} \\
\mathrm{a}\end{array}$ \\
\hline
\end{tabular}

Legenda: Teste de Tukey para comparação de médias entre Áreas:

CC - Canal da Cosipa; RM - Rio Marina; RC - Rio Cascalho.

Tabela 42. Concentração de metais nas folhas de matrizes de $R$. mangle

\begin{tabular}{|c|c|c|c|c|c|c|}
\hline \multirow{2}{*}{$\begin{array}{r}\text { Parâmetro } \\
\text { Zinco }(\mu \mathrm{g} / \mathrm{g})\end{array}$} & \multicolumn{3}{|c|}{$\begin{array}{l}\text { Metais nas folhas I área } \\
\text { Análise de Variância }\end{array}$} & \multicolumn{3}{|c|}{$\begin{array}{c}\text { Teste de Tukey } \\
\text { (5\% de probabilidade) }\end{array}$} \\
\hline & 5,09 & 2,39 & $0,1109 \mathrm{~ns}$ & $\begin{array}{l}\text { CC } \\
\text { RM } \\
\text { RC }\end{array}$ & $\begin{array}{l}5,88 \\
4,76 \\
4,64\end{array}$ & $\begin{array}{l}\mathrm{a} \\
\mathrm{a} \\
\mathrm{a}\end{array}$ \\
\hline Cobre $(\mu \mathrm{g} / \mathrm{g})$ & 2,10 & 1,14 & $0,3332 \mathrm{~ns}$ & $\begin{array}{l}\mathrm{RC} \\
\mathrm{RM} \\
\mathrm{CC}\end{array}$ & $\begin{array}{l}3,42 \\
1,65 \\
1,23\end{array}$ & $\begin{array}{l}\mathrm{a} \\
\mathrm{a} \\
\mathrm{a}\end{array}$ \\
\hline Chumbo $(\mu \mathrm{g} / \mathrm{g})$ & 1,16 & 9,21 & 0,0009 ** & $\begin{array}{l}\mathrm{CC} \\
\mathrm{RC} \\
\mathrm{RM}\end{array}$ & $\begin{array}{l}1,79 \\
0,89 \\
0,79\end{array}$ & $\begin{array}{l}a \\
b \\
b\end{array}$ \\
\hline Níquel $(\mu \mathrm{g} / \mathrm{g})$ & 0,62 & 4,78 & 0,0167 * & $\begin{array}{l}\text { CC } \\
\text { RC } \\
\text { RM }\end{array}$ & $\begin{array}{l}1,03 \\
0,43 \\
0,40\end{array}$ & $\begin{array}{l}a \\
b \\
b\end{array}$ \\
\hline Cromo $(\mu \mathrm{g} / \mathrm{g})$ & 0,67 & 11,30 & 0,0003 ** & $\begin{array}{l}\mathrm{CC} \\
\mathrm{RM} \\
\mathrm{RC}\end{array}$ & $\begin{array}{l}1,14 \\
0,51 \\
0,21\end{array}$ & $\begin{array}{l}a \\
b \\
b\end{array}$ \\
\hline
\end{tabular}

Legenda: Teste de Tukey para comparação de médias entre Áreas:

CC - Canal da Cosipa; RM - Rio Marina; RC - Rio Cascalho. 
Da Tabela 40 avalia-se que para os propágulos não há diferença significativa entre as áreas para os metais $\mathrm{Zn}$ e $\mathrm{Pb}$. Para $\mathrm{Ni}$ a significância foi a 5\%, sendo o Rio Cascalho a área mais afetada, seguida do Rio Mariana. Para $\mathrm{Cu}$ a diferença entre áreas é altamente significativa, com Rio Mariana e Rio Cascalho apresentando as maiores concentrações. Para todos os metais a área testemunha apresentou as menores concentrações.

Da Tabela 41 tem-se, para mudas, o $\mathrm{Pb}$, Ni e $\mathrm{Cr}$ não diferindo entre si nas áreas, porém $\mathrm{Zn}$ e $\mathrm{Cu}$ foram altamente significativos, com o Canal da Cosipa com menores concentrações para ambos; no Rio Mariana a maior concentração foi de Zn, enquanto que no Rio Cascalho esta foi maior para o $\mathrm{Cu}$. $\mathrm{Na}$ área testemunha as concentrações estiveram abaixo do LD.

Da Tabela 42 depreende-se, para folhas, que Zn e Cu não diferem nas áreas; para $\mathrm{Pb}$ e $\mathrm{Cr}$ constatou-se diferença altamente significativa e para $\mathrm{Ni}$ significativa a 5\%. Pb e $\mathrm{Ni}$ apresentam concentração superior no Canal da Cosipa, seguido do Rio Cascalho e Rio Mariana. Para o Cr, o Canal da Cosipa apresenta a maior concentração, seguido do Rio Mariana e Rio Cascalho. As concentrações destes metais na área testemunha estiveram abaixo do LD.

Com relação à parte da planta onde há maior concentração de metais, os resultados indicaram que: $\mathrm{Zn}$ - folha > mudas > propágulo; $\mathrm{Cu}$ - folha > propágulo > muda; $\mathrm{Pb}$ - propágulo > folha > muda; $\mathrm{Ni}-$ folha > propágulo > muda e $\mathrm{Cr}$ - apareceu em maior concentração nas mudas. Oliveira et al. (1998) constaram que na maioria dos casos a concentração de metais se deu na seqüência raízes > folhas > frutos, e nestes três constituintes estudados, a concentração se deu na seqüência $\mathrm{Fe}>\mathrm{Mn}>\mathrm{Zn}>\mathrm{Cu}>\mathrm{Ni}>\mathrm{Pb}>\mathrm{Cr}$. Porém, isto se refere às partes de um mesmo indivíduo arbóreo e no caso em questão, frutos e folhas não foram coletados na mesma árvore e a concentração para o $\mathrm{Pb}$ ser maior no propágulo pode ser devido à coleta de propágulos no chão (poderiam ter estado em contato direto com o meio contaminado, sem contaminação via translocação entre as partes da planta. 


\subsection{Qualidade ambiental}

Foram consideradas as informações disponíveis referentes à concentração média de metais no solo (Silva, 2004), água e organismos (CETESB, 2001) e material vegetal (do presente estudo), sendo as médias padronizadas em $\mu \mathrm{g} / \mathrm{g}$. As concentrações de cada metal nos compartimentos foram somadas para obtenção de um único valor de concentração no ambiente. A somatória proposta justifica-se pela ciclagem de nutrientes nos ecossistemas, havendo uma distribuição dos elementos nos vários compartimentos do meio.

A soma foi realizada somente para metais para os quais se dispunha da concentração nos quatro compartimentos (faltando um ou mais não foi possível obter a concentração no meio). Para a soma, os resultados LD foram considerados como o próprio limite de detecção. As médias para os parâmetros dos compartimentos do meio são apresentadas na Tabela 43.

Paralelamente, para cada metal foi avaliada a periculosidade visando ponderar o risco em função do potencial dano à saúde humana. Para expressar a periculosidade se resgatou as informações do item "2.2.1 - Os metais" sobre os efeitos dos metais à saúde humana, sendo atribuídos pesos (variando de 1 a 10) em função do potencial dano de sua ação, da seguinte forma: Sn - peso 1 , $\mathrm{Cu}-2, \mathrm{Zn}-3, \mathrm{Cr}-5, \mathrm{Ni}-5, \mathrm{Cd}-7, \mathrm{~Pb}-9 \mathrm{e} \mathrm{Hg}-10$.

Tal valoração é subjetiva, mas permite uma avaliação combinada, ponderada dos efeitos dos metais na análise em pauta. Atribuídos os pesos, estes foram multiplicados pela concentração no meio obtendo-se a média ponderada para cada metal. A avaliação conjunta dos metais, por meio da soma ponderada, foi o valor de referência da qualidade ambiental da área, sendo as áreas com maior valor consideradas piores ambientalmente.

A Tabela 44 apresenta os metais associados ao peso - periculosidade, à soma ponderada com o peso e a totalização para as áreas, valor este que permite a classificação comparativa das áreas quanto à qualidade ambiental. 
Tabela 43. Concentração média de metais nos compartimentos do meio e no ambiente

\begin{tabular}{|c|c|c|c|c|c|}
\hline \multirow{2}{*}{$\begin{array}{l}\text { Metais } \\
(\mu \mathrm{g} / \mathrm{g})\end{array}$} & \multicolumn{4}{|c|}{ Compartimentos do meio } & \multirow{2}{*}{$\begin{array}{c}\text { Ambiente } \\
\text { Soma }\end{array}$} \\
\hline & Água & Solo & Material Vegetal & Organismo & \\
\hline \multicolumn{6}{|c|}{ Canal da Cosipa } \\
\hline Sn & Não avaliado & Não avaliado & LD & Não avaliado & -- \\
\hline $\mathrm{Hg}$ & $<0,0001$ & Não avaliado & LD & 0,98 & -- \\
\hline $\mathrm{Zn}$ & $<0,01$ & 83,94 & 3,53 & 19,70 & 107,18 \\
\hline $\mathrm{Cu}$ & $<0,003$ & 11,67 & 1,04 & 6,82 & 19,53 \\
\hline $\mathrm{Ni}$ & 0,05 & 21,06 & 0,57 & 0,21 & 21,89 \\
\hline $\mathrm{Cr}$ & $<0,05$ & 76,80 & 0,98 & 0,20 & 78,03 \\
\hline $\mathrm{Pb}$ & $<0,002$ & 21,50 & 1,12 & 0,18 & 22,80 \\
\hline $\mathrm{Cd}$ & $<0,001$ & Não avaliado & LD & 0,01 & -- \\
\hline \multicolumn{6}{|c|}{ Rio Cascalho } \\
\hline Sn & Não avaliado & Não avaliado & LD & Não avaliado & -- \\
\hline $\mathrm{Hg}$ & $<0,0001$ & Não avaliado & LD & 0,07 & -- \\
\hline $\mathrm{Zn}$ & $<0,01$ & 43,25 & 3,45 & 17,00 & 63,71 \\
\hline $\mathrm{Cu}$ & $<0,003$ & 8,49 & 1,69 & 4,12 & 14,30 \\
\hline $\mathrm{Ni}$ & 0,06 & 16,61 & 0,46 & 0,27 & 17,40 \\
\hline $\mathrm{Cr}$ & $<0,05$ & 88,50 & 0,50 & 0,25 & 89,30 \\
\hline $\mathrm{Pb}$ & $<0,002$ & 15,13 & 0,72 & 0,07 & 15,92 \\
\hline $\mathrm{Cd}$ & $<0,001$ & Não avaliado & $12,38 \times 10^{-3}$ & $<0,01$ & -- \\
\hline \multicolumn{6}{|c|}{ Rio Mariana } \\
\hline Sn & Não avaliado & Não avaliado & LD & Não avaliado & -- \\
\hline $\mathrm{Hg}$ & $<0,01$ & Não avaliado & LD & 0,05 & -- \\
\hline $\mathrm{Zn}$ & $<0,003$ & 50,53 & 3,39 & 24,24 & 78,16 \\
\hline $\mathrm{Cu}$ & 0,05 & 7,01 & 1,10 & 4,68 & 12,84 \\
\hline $\mathrm{Ni}$ & $<0,05$ & 15,08 & 0,33 & 0,17 & 15,63 \\
\hline $\mathrm{Cr}$ & $<0,002$ & 61,71 & 0,64 & 0,18 & 62,53 \\
\hline $\mathrm{Pb}$ & $<0,001$ & 13,45 & 0,72 & 0,08 & 14,25 \\
\hline $\mathrm{Cd}$ & $<0,01$ & Não avaliado & LD & $<0,01$ & -- \\
\hline \multicolumn{6}{|c|}{ Ilha do Cardoso } \\
\hline Sn & Não avaliado & Não avaliado & LD & Não avaliado & -- \\
\hline $\mathrm{Hg}$ & Não avaliado & Não avaliado & LD & Não avaliado & -- \\
\hline $\mathrm{Zn}$ & Não avaliado & 20,38 & LD & Não avaliado & -- \\
\hline $\mathrm{Cu}$ & Não avaliado & 2,96 & LD & Não avaliado & -- \\
\hline $\mathrm{Ni}$ & Não avaliado & 9,14 & LD & Não avaliado & -- \\
\hline $\mathrm{Cr}$ & Não avaliado & 46,06 & LD & Não avaliado & -- \\
\hline $\mathrm{Pb}$ & Não avaliado & 8,39 & LD & Não avaliado & -- \\
\hline $\mathrm{Cd}$ & Não avaliado & Não avaliado & LD & Não avaliado & -- \\
\hline
\end{tabular}


Tabela 44. Classificação da Qualidade Ambiental do Manguezal baseada na concentração média ponderada de 5 metais

\begin{tabular}{|c|c|c|c|c|c|c|c|}
\hline \multicolumn{2}{|l|}{ Geral } & \multicolumn{2}{|c|}{ Canal da Cosipa } & \multicolumn{2}{|c|}{ Rio Cascalho } & \multicolumn{2}{|c|}{ Rio Mariana } \\
\hline $\begin{array}{c}\text { Peso de } \\
\text { periculosidade }\end{array}$ & $\begin{array}{l}\text { Metais } \\
(\mu \mathrm{g} / \mathrm{g})\end{array}$ & Soma & $\begin{array}{c}\text { Soma } \\
\text { ponderada }\end{array}$ & Soma & $\begin{array}{c}\text { Soma } \\
\text { ponderada }\end{array}$ & Soma & $\begin{array}{c}\text { Soma } \\
\text { ponderada }\end{array}$ \\
\hline 3 & $\mathrm{Zn}$ & 107,18 & 321,54 & 63,71 & 191,13 & 78,16 & 234,48 \\
\hline 2 & $\mathrm{Cu}$ & 19,53 & 39,06 & 14,3 & 28,60 & 12,84 & 25,68 \\
\hline 5 & $\mathrm{Ni}$ & 21,89 & 109,45 & 17,4 & 87,00 & 15,63 & 78,15 \\
\hline 5 & $\mathrm{Cr}$ & 78,03 & 390,15 & 89,3 & 446,5 & 62,53 & 312,65 \\
\hline 9 & $\mathrm{~Pb}$ & 22,8 & 205,20 & 15,92 & 143,28 & 14,25 & 128,25 \\
\hline \multirow{2}{*}{\multicolumn{2}{|c|}{$\begin{array}{c}\text { TOTAL } \\
\text { Classificação } \\
\text { comparativa da } \\
\text { Qualidade Ambiental }\end{array}$}} & -- & 1065,40 & -- & 896,51 & -- & 779,21 \\
\hline & & \multicolumn{2}{|c|}{ Pior } & \multicolumn{2}{|c|}{ Intermediária } & \multicolumn{2}{|c|}{ Melhor } \\
\hline
\end{tabular}

Assim, tem-se que o Canal da Cosipa é a área de pior qualidade, o Rio Cascalho apresenta qualidade intermediária e o Rio Mariana encontra-se na melhor situação quanto à qualidade ambiental no que concerne à contaminação por metais, o que corrobora a avaliação visual do bosque apresentada nos perfis e avaliações das áreas de amostragem.

Pode-se inferir que a contaminação por metais está associada ao padrão do bosque, sendo este um dos tensores ambientais responsáveis pela reposta negativa no estabelecimento de $R$. mangle na Baixada Santista, atestando a hipótese inicialmente formulada.

É necessário ressaltar que a avaliação de metais neste trabalho, assim como nos trabalhos referenciados, não abrangeu todos os metais, assim como foi desconsiderado o compartimento atmosfera, que é responsável por mais uma entrada de metais via deposição de partículas e dispersão gasosa. Adicionalmente, substâncias poluentes não metálicas não foram consideradas. Estes aspectos tornam as conclusões apenas indicativas.

Destaca-se ainda que a indisponibilidade de dados que possibilitassem a avaliação da área testemunha (IC) resultou em uma lacuna metodológica nas análises comparativas realizadas. 
E por fim, a inexistência de um padrão de concentração de metais em plantas torna as avaliações subjetivas, sendo importante que se intensifiquem as ações voltadas à definição de tais padrões, essenciais para o manejo e conservação das áreas de Manguezal, especialmente àquelas inseridas em regiões antropizadas e alteradas como a Baixada Santista.

\subsection{Observação adicional - Lagartas}

Até então não se tinha comprovação da causa do desfolhamento e secamento de árvores de mangue branco ao longo de vários rios em Cubatão, São Sebastião e Bertioga. Havia hipóteses de contaminação ou alguma praga, desconfiava-se de lagartas pelas características da vegetação predada.

No momento da coleta de propágulos, ao acaso, foram encontrados e coletados vários exemplares da lagarta preta que se utiliza uma espécie de fio (semelhante à teia de aranha) para deslocar-se entre árvores, e abriga-se em folhas enroladas e presas com a mesma teia.

Os indivíduos coletados, enviados para o Departamento de Entomologia da ESALQ e para especialistas de Brasília foram identificados como a Hyblae puera, uma espécie asiática encontrada anteriormente apenas uma vez no Brasil, em Goiás, atacando árvores de Teca (Tectona grandis).

A presença do inseto no Brasil já despertava perplexidade nos especialistas, principalmente em relação a como o inseto teria chegado no interior do continente (Goiás) onde foi primeiramente constado. Nos manguezais, a hipótese é a entrada pelo Porto, vindas nas caixotarias de navios de carga oriundos de áreas asiáticas.

Durante as várias campanhas de campo para coleta de dados, algumas áreas atacadas pela praga foram visitadas, porém não foram realizadas novas coletas de exemplares de lagartas, uma vez que com a queda da 
temperatura estas desapareceram ${ }^{14}$. Em relação à vegetação atacada, observou-se que vários trechos de Manguezal que estavam desfolhados e secos se recuperaram tendo brotações novas após a época chuvosa, porém, em trechos onde o ataque foi mais severo, várias árvores de $A$. shaueriana não brotaram, permanecendo mortas-em-pé no local.

Mastaller (1990) citando tensores biológicos naturais que agem sobre as espécies de Manguezais descreve a presença de microorganismos e fungos patogênicos, besouros e traças freqüentemente atacando propágulos de Rhizophora e plântulas de Ceriops e larvas de uma borboleta que causa desfoliação em Avicennia, na Tailândia; esta última pode ser a mesma espécie encontrada na Baixada Santista.

As fotos apresentadas nas Figuras 72 a 77, a seguir ilustram áreas afetadas pela praga, área onde a lagarta foi encontrada, além da própria lagarta e das mariposas.

\footnotetext{
${ }^{14}$ Ressalta-se que esta foi uma informação complementar dentro do escopo do estudo, tendo sido obtida casualmente. Assim, novos exemplares não foram encontrados, porém isto pode ser conseqüência da não sistematização desta observação.
} 


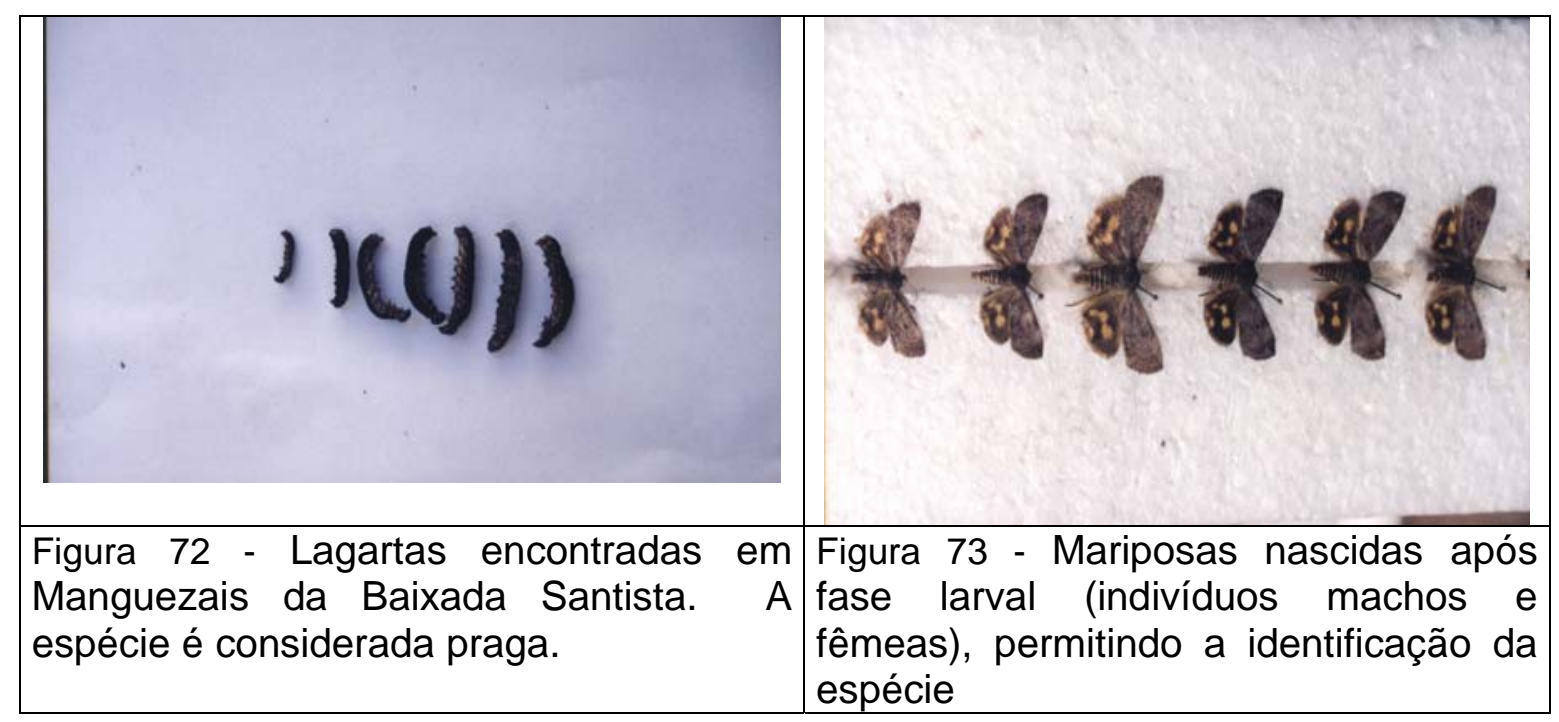

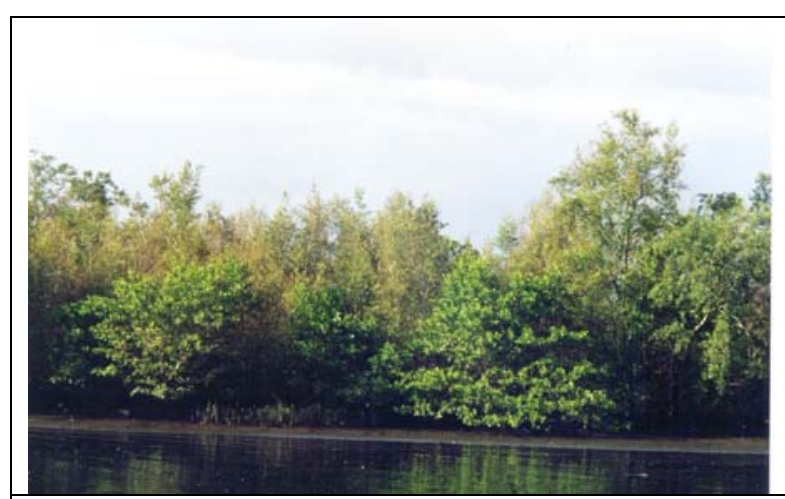

Figura 74 - Trecho do bosque atacado por lagartas (Rio Mariana).

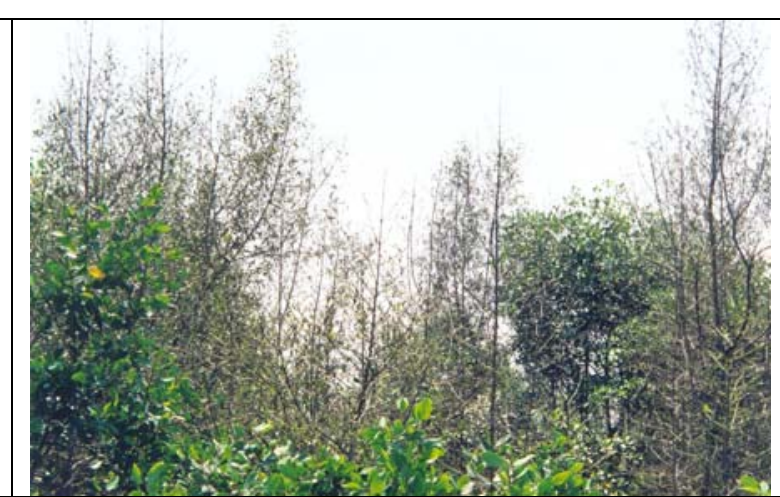

Figura 75 - Detalhe das copas secas em função da ocorrência das lagartas.

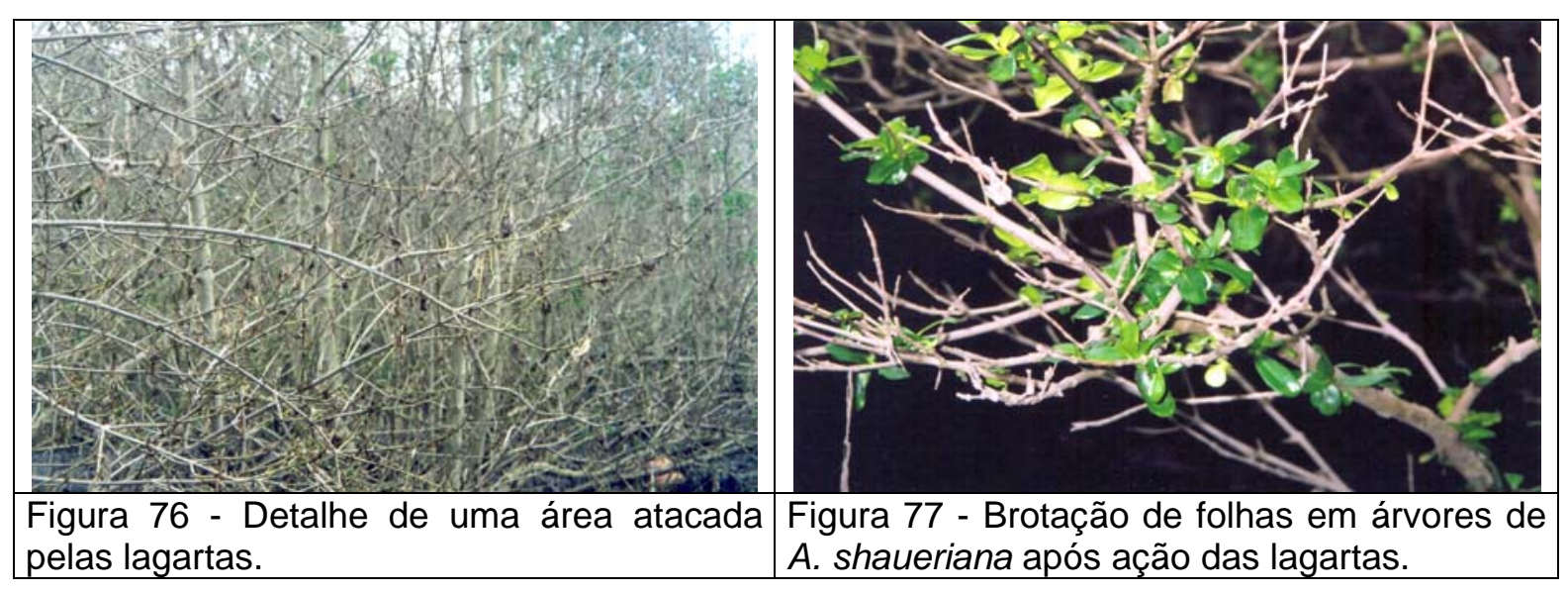




\section{CONCLUSÕES}

Uma síntese conclusiva dos resultados obtidos é apresentada a seguir.

\section{Áreas de amostragem e agentes tensores}

+ CC: principais agentes tensores: efluentes industriais, navegação (efeito de marolas), esgotos domésticos, resíduos sólidos domiciliares e chorume.

* RC: principais agentes tensores: os mesmos do CC com exceção de marolas e inclusão do ataque de praga (lagarta).

RM: principais agentes tensores: esgotos domésticos in natura, resíduos sólidos domiciliares, chorume, organoclorados carreados, efluentes industriais e ataque de praga (lagarta).

IC: Unidade de Conservação, distante de centros urbanizados ou industrializados, isolada - sem tensores associados à contaminação química.

A fotointerpretação corrobora a situação diagnosticada quanto aos tensores ambientais levantados no histórico das áreas avaliadas.

\section{Florescimento e frutificação}

Floração pode ocorrer no mesmo período que a frutificação, mas esses eventos não são sincronizados na população.

Floração e frutificação podem variar assincronicamente entre os indivíduos da mesma espécie, entre espécies e entre áreas.

Padrão similar de florescimento e frutificação no CC e RC ( \pm anual) e no RM foram fenofases contínuas e com maior produção de frutos. 


\section{Características do propágulo}

* Massa dos propágulos: IC>CC $>\mathrm{RM}>\mathrm{RC}$.

Diâmetro do centro e base dos propágulos: médias similares com afinamento no ápice. Centro>CC e ápice>IC, Base não diferiu nas áreas.

* Comprimento do propágulo não diferiu entre áreas.

\section{Características do propágulo e desenvolvimento da muda}

* Avaliação não representativa: poucas repetições devido alta mortalidade.

* Tendências demonstram não haver correlação entre os parâmetros medidos para o propágulo, para a muda e entre o propágulo e a muda.

* Desenvolvimento da muda independente das características do propágulo - plantio de qualquer tipo de propágulo (dimensões e forma).

* Enraizamento dos propágulos dificulta plantio. Presença prévia de raízes não garante o melhor desenvolvimento posterior da muda.

\section{Secagem dos propágulos}

* Não há relação entre as medidas (comprimento, diâmetros), entre as massas (MU e MS) e entre as medidas e as massas dos propágulos.

+ Conversão MU:MS não está relacionada às dimensões do propágulo.

\& Perda de água é extremamente variável para propágulos, implicando em taxas de conversão não lineares.

Taxa média de conversão MU:MS calculada para as áreas, porém com emprego questionável em função da grande variação nos dados. 


\section{Projeção e parâmetros da copa da árvore matriz}

* Copas das árvores de R. mangle são caracteristicamente irregulares e podem estar deslocadas em relação ao tronco principal.

- Projeção média de copa para matrizes: $R C>R M>C C$.

* Áreas diferem quanto aos parâmetros da copa (ramos/galho; folhas/ramo; $\mathrm{MU}$ do ramo e MS do ramo): $\mathrm{CC}>\mathrm{IC}>\mathrm{RM}>\mathrm{RC}$.

No CC, as copas se projetam menos mas apresentam mais ramos, mais folhas/galho e maior massa (MU e MS).

* No RC há copas com maior projeção mas menos densas e mais leves. No RM a projeção de copa e características dos ramos e folhas está em situação intermediária entre as áreas.

\section{Estabelecimento de indivíduos jovens sob a árvore matriz}

- Quantidade de propágulos (enraizados e superficiais) de R. mangle e de A. shaueriana sob as matrizes não apresentou diferenças entre áreas.

- Quantidade de mudas de R. mangle de $20,1 \mathrm{~cm}$ e $60 \mathrm{~cm}$ não apresentou diferenças entre áreas; para mudas até $20 \mathrm{~cm}$ e de 60,1 a $80 \mathrm{~cm}$ variaram.

Regeneração sob matrizes (ambas as espécies), muito pequena nas três áreas; recrutamento desequilibrado (poucas mudas na $1^{\mathrm{a}}$. classe de altura).

\section{Perfil horizontal e projeção de copa no bosque}

Visualmente, os bosques da Baixada Santista apresentam situação diferenciada (CC- mais degradado, RM- mais conservado RC- intermediário).

A. shaueriana, apesar de certa irregularidade na projeção de copa apresenta estrutura da copa no geral mais uniforme do que $R$. mangle.

Dossel mais fechado : $\mathrm{RM}>\mathrm{RC}>\mathrm{CC}$. 


\section{Avaliação de indivíduos adultos no bosque}

Altura da copa de R. mangle e A. shaueriana não difere entre áreas, mas as áreas diferem para projeção média da copa.

- Características dos indivíduos do bosque (No. brotos, altura raiz, altura árvore, altura fuste, DAP, projeção média copa) diferem entre áreas.

Altura raiz e do fuste e DAP $\rightarrow \mathrm{RM}>\mathrm{CC}>\mathrm{RC}$; Altura média árvore $\rightarrow$ $\mathrm{RM}>\mathrm{RC}>\mathrm{CC}$; Número médio brotos $\rightarrow \mathrm{RC}>\mathrm{CC}>\mathrm{RM}$.

R. mangle é responsável pela diferenciação do bosque, pois para a $A$. shaueriana somente o No. brotos diferiu entre áreas enquanto que para a $R$. mangle não houve diferenças apenas para No. brotos e projeção de copa.

RM apresenta árvores e altura da raiz mais altas, maiores DAPs e segunda melhor posição em relação a altura do fuste e da copa.

\section{Estabelecimento de indivíduos jovens sob as árvores do bosque}

Áreas diferem entre si para quantidade de propágulos, para classes de altura das mudas (exceção $R$. mangle $>80 \mathrm{~cm}$ ) e entre as espécies.

4 Propágulos de R. mangle são mais abundantes para: $\mathrm{RM}>\mathrm{RC}>\mathrm{CC}$.

* Mudas pequenas (até $80 \mathrm{~cm}$ ) de $A$. shaueriana aparecem nas áreas em quantidade muito superior em comparação com a $R$. mangle.

- Mudas $>80 \mathrm{~cm}$ são mais abundantes nas áreas para R. mangle do que $A$. shaueriana.

+ RC apresenta maior quantidade de mudas (grandes e pequenas) para ambas as espécies ou considerando apenas a $A$. shaueriana.

RM apresenta maior quantidade de mudas pequenas de $R$. mangle. 


\section{Taxa de mortalidade no plantio de propágulos}

Mortalidade alta nas três áreas: RM (100\% em 10 e 16 meses) > CC (85\% em 3 meses, 72\% em 7 meses, 96\% em 13 meses) > RM (92\% em 9 meses, 54\% em 6 meses, 77\% em 14 meses) > IC (86\% em 20 meses).

* Mortalidade maior para propágulos originados da IC do que da Baixada.

Causas da mortalidade desconhecidas; supostamente: arraste (correnteza), submersão prolongada, nódulos de barro no propágulo (RC).

Regeneração natural presente e com intensidade variável nas áreas.

\section{Análise do solo (Silva, 2005)}

- Condições fisico-químicas com ampla variação na matéria orgânica, pH (neutralidade) e condições de oxidação-redução (em geral anóxicas).

\& CC - solos são poluídos por Cu e Cr e contaminado por Ba ; RC - solos poluídos por $\mathrm{Cr}$ e contaminados por $\mathrm{Ba}$; RM - solos poluídos por $\mathrm{Ba}$, Mo, As e Cr ; IC - solos não são poluídos nem contaminados no Rio Perequê.

\section{Análise de organismos e água (CETESB, 2001a)}

Concentração dos metais avaliados estão abaixo do padrão legal.

* Hg: ampla distribuição; redução nas concentrações para organismos.

* Zn: se manteve para alguns, aumentou para outros tipos de organismos.

* Cu: reduziu na água e peixes, aumentou em siris (Estuário São Vicente).

* Ni: aumentou nos sedimentos e siris do Rio Cubatão.

* Cr: aumentou nos organismos.

* Pb: contaminação relacionada à indústrias de Cubatão; maior na Cosipa.

- Cd: concentração no Estuário São Vicente; redução em organismos. 


\section{Análise de material botânico}

- Zn, Cu, Pb maior concentração em mudas do CC do que IC.

- Ni, Cr, CD maior concentração na regeneração natural do que mudas plantadas no CC.

Folhas e Mudas do CC mais contaminadas do que IC.

+ Propágulos do CC mais contaminados do que o IC para Zn, Cu, Ni e Pb.

* Mudas do RC mais contaminadas por $\mathrm{Zn}, \mathrm{Cu}, \mathrm{Ni}, \mathrm{Cr}, \mathrm{Pb}$ e $\mathrm{Cd}$ do que IC.

* Folhas e Mudas do RC mais contaminadas do que IC.

+ Propágulos do RC com maior concentração de Zn e Ni do que na IC.

* Mudas do RM foram somente da regeneração natural e apresentaram maior concentração de $\mathrm{Zn}, \mathrm{Cu}, \mathrm{Cr}, \mathrm{Pb}, \mathrm{Cd}$.

* Folhas e Mudas do RM mais contaminadas do que o IC.

* Propágulos do RM mais contaminados do que IC para Zn, Cu, Ni e Pb.

* IC tem as maiores concentrações de Zn, Cu, Ni e Pb nos propágulos.

* Nas quatro áreas as concentrações de Sn e Hg para propágulos, mudas e folhas foram abaixo do LD e de Cd foi abaixo do LD para propágulos.

— Propágulos: Zn e Pb não diferem nas áreas. Ni - RC>RM ; Cu - RM>RC.

* Mudas: Pb, Ni, Cr não diferem entre áreas. Zn, Cu são menores no CC. Zn maior no RM. Cu maior no RC.

Folhas: Zn, $\mathrm{Cu}$ não diferem entre áreas. $\mathrm{Pb}$ e $\mathrm{Ni}$ são maiores no CC $>$ RC $>$ RM. Cr maior no $C C>R M>R C$.

* Concentração dos metais nas partes da planta no CC:

Zn (folha>muda>propágulo) $\quad \mathrm{Cu}$ (folha>muda>propágulo)

$\mathrm{Ni}$ (folha>muda>propágulo) $\quad \mathrm{Cr}$ (folha>muda>propágulo)

$\mathrm{Pb}$ (folha>propágulo $>$ muda) $\quad \mathrm{Cd}$ (muda>propágulo=folha). 
* Concentração dos metais nas partes da planta para o RC:
Zn (folha>muda>propágulo)
Cu (muda>propágulo>folha)
Ni (propágulo>folha>muda)
$\mathrm{Cr}$ (muda>folha>propágulo)
$\mathrm{Pb}$ (folha>propágulo>muda)
Cd (folha>muda>propágulo).

* Concentração dos metais nas partes da planta para o RM:

Zn (folha>muda>propágulo)

Cu (folha>muda>propágulo)

$\mathrm{Ni}$ (folha>propágulo>muda)

$\mathrm{Cr}$ (muda>folha>propágulo)

$\mathrm{Pb}$ (folha $>$ muda $>$ propágulo)

Cd (muda>propágulo=folha).

- Concentração dos metais nas partes da planta para o IC:

Zn (folha $>$ mudas $>$ propágulo)

$\mathrm{Cu}$ (folha>propágulo>muda)

$\mathrm{Pb}$ (propágulo $>$ folha $>$ muda)

Ni (folha>propágulo>muda)

$\mathrm{Cr}$ (>nas mudas)

\section{Avaliação da qualidade ambiental das áreas}

* Qualidade ambiental - contaminação de 5 metais em solo, água, material vegetal e organismos: Pior no CC; Intermediária no RC; Melhor no RM.

* Inexistência de um padrão de concentração de metais em plantas torna as avaliações subjetivas.

* Os resultados foram indicativos devido à não abordagem de todos os metais, desconsideração do compartimento atmosfera e de outras substâncias poluentes não metálicas e indisponibilidade de dados para avaliação da área testemunha. 


\section{Observação adicional - Lagartas}

Lagartas - praga nos Manguezais da Baixada são da espécie Hyblae puera e desaparecem com a diminuição da temperatura.

Predação preferencial de $A$. shaueriana, formando reboleiras de árvores com copa desfolhadas e secas.

Recuperação da planta atacada depende da intensidade da predação, podendo haver recuperação por brotação.

\section{Conclusões gerais}

O Canal da Cosipa foi idenficado como a área de pior qualidade ambiental. Apresenta solo poluído por $\mathrm{Cu}$ e $\mathrm{Cr}$ e contaminado por $\mathrm{Ba}$; organismos com traços de metais, destacando-se o $\mathrm{Pb}$; propágulos, mudas e especialmente folhas com traços de $\mathrm{Pb}$, Ni e $\mathrm{Cr}$. Nestas condições de contaminação, esta área apresenta menor período de florescimento e frutificação, pequena abundância de propágulos sobre 0 solo, menor estabelecimento de mudas, alta mortalidade de mudas plantadas e regeneração natural menos expressiva, dossel mais aberto devido à densidade do bosque e copas menores, além de menor porte, quando comparado à área de melhor qualidade ambiental na Baixada Santista, o Rio Mariana.

Comprovou-se então a hipótese de "interferência negativa dos metais sobre o estabelecimento de R. mangle nos Manguezais da Baixada Santista", uma vez que a concentração de metais mostrou-se como um dos fatores de tensão ambiental associado à menor reposta no estabelecimento da espécie e piores características do bosque. 


\section{REFERÊNCIAS BIBLIOGRÁFICAS}

ABRAÃO, G.R. Técnicas para a implantação de espécies nativas de manguezal em aterro hidráulico visando a recomposição de ecossistemas costeiros (Via expresso Sul - Ilha de Santa Catarina - Brasil). Santa Catarina, 1998. 52p. Dissertação (Mestrado) - Centro de Ciências Agrárias, Universidade Federal de Santa Catarina.

ADAMS, D.A. Factors influencing vascular plant zonation in North Caroline salt marshes. Ecology, v. 44, p. 445-456, 1963.

AMBIENTE ÁGUAS. Mangue. www.ambientebrasil.com.br. (21 mar.2002).

ANDRADE, R.C.B.; PATCHINEELAM, S.R. Especiação de metais-traço em sedimentos de florestas de manguezais com Avicennia e Rhizophora. Química Nova, v.23, n.6, 8p., 2000. www.scielo.br. (12 fev. 2004).

ARAÚJO, B.R.N.; QUEIROZ, A.F. S.; SANTOS J.J. et al. Caracterização geoquímica do manguezal do estuário do Rio Itanhaém, Alcobaça-BA: Resultados preliminares dos teores de matéria orgânica (M.O.), carbono orgânico (C) e sua relações com parâmetros físico-químicos. In: SIMPÓSIO DE ECOSSISTEMAS BRASILEIROS, 4., Águas de Lindóia, 1998. Anais. Águas de Lindóia: ACIESP, 1998. p.117-123.

BENOIT, G.; OKTAI-MARSHALL, S.D.; HOOD, E.M. et al. Partioning of $\mathrm{Cu}, \mathrm{Pb}$, $\mathrm{Ag}, \mathrm{Zn}, \mathrm{Fe}, \mathrm{Al}$ and $\mathrm{Mn}$ between filter-retained particles, colloids and solution in six Texas estuaries. Marine Chemistry, v.45, p.307-336, 1994.

BOHORQUEZ, C.A.; PRADA, M.C. Transplant of Rhizophora mangle em el Parque Nacional Corales del Rosário, Columbia. Revista de Biologia Tropical, v.36, p. 555-557, 1986.

BRANCO, S.M. O fenômeno Cubatão na visão do ecólogo. São Paulo: CETESB, ASCETESB, 1984. 112p.

CAMACHO, J.H.; HILDEBRAND, P. von; LEON, R.A. Problemática del manejo de manglares com especial referencia al sector occidental de la cienaga grande de Santa Marta, Magdalena, Colômbia. In: SEMINÁRIO UNESCO, Cali, 1980. Tema VII: Restauracion, manejo y conservacion. Cali:UNESCO, 1980. p.365-385. 
CAMARA, I.G. Plano de ação para a Mata Atlântica. São Paulo: Fundação SOS Mata Atlântica, Ed. Interação, 1991.

CARDONA, P.; BOTERO, L. Soil characteristics and vegetation structure in a heavily deterioted mangrove forest in the Caribbean Coast of Colombia. Biotropica, v.30, p.24-34, 1998.

CARMO, T.M.S.; ALMEIDA, R.; OLIVEIRA, A.R. et al. Caracterização de um trecho do manguezal do Rio da Passagem, Baía de Vitória, Vitória-ES, Brasil. In: SIMPÓSIO DE ECOSSISTEMAS BRASILEIROS, 4., Águas de Lindóia, 1998a. Anais. Águas de Lindóia: ACIESP, 1998. p.6-15.

CARMO, T.M.S.; GOES, P.; ALMEIDA, A.P.L.S. et al. Caracterização do manguezal do Rio Reis Magos, Fundão, Espírito Santo. In: SIMPÓSIO DE ECOSSISTEMAS BRASILEIROS, 4., Águas de Lindóia, 1998b. Anais. Águas de Lindóia: ACIESP, 1998. p.17-29.

CARTER, M.R; BURNS, L.A.; CAVINDER, T.R. et al. Ecosystems analysis of in the Big Cypress swamp and estuaries. Atlanta: U.S. Environmental Protection Agency, Region IV, 1973. 479p.

CARVALHÃES, M.A. Florística e estrutura de mata sobre restinga na Juréia, Iguape, SP. São Paulo, 1997. 110p. Dissertação (Mestrado) - Instituto de Biociências, Universidade de São Paulo.

CEARÁ. Secretaria de Desenvolvimento Urbano e Meio Ambiente. Que é manguezal. Fortaleza, 1992. 25p.

CHAPMAN, V.J. Mangrove biogeography. In: INTERNATIONAL SYMPOSIUM ON BIOLOGY AND MANAGEMENT OF MANGROVES, Honolulu, 1975. Honolulu: East-West Center, 1975. p.3-22.

CHIU, C.Y.; CHOU, C.H. The distribution and influence of heavy metals in mangrove forest of the Tamshui Estuary in Taiwan. Soil Science and Plant Nutrition, v.37, p.659-669, 1991.

CHOONG, E.T.; WIRAKUSUMAH, R.S.; ACHMADI, S.S. Mangrove Forest resources in Indonésia. Forest Ecology and Management, n.33/34, p.45-57, 1990.

CINTRÓN, G.; SCHAEFFER-NOVELLI, Y. Proposta para estudo dos recursos de marismas e manguezais. São Paulo: USP, IO, 1981. 13p. (Relatório Interno do Instituto Oceanográfico).

CINTRÓN, G.; SCHAEFFER-NOVELLI, Y. Caracteristicas y desarrollo estructural de los manglares de norte $y$ sur América. Ciência Interamericana, v.25, p.4-15, 1985. 
CINTRÓN, G.; RODRIGUES, F.O.; ROQUETTI-HUMAYTÁ, M.H. et al. Avaliação dos teores de metais pesados em três áreas de manguezais da Baixada Santista. São Paulo: CETESB, s.d. 10p. (Relatório interno).

CLINE, J.E. Spectrophotometric determination of hydrogen sulfide in natural waters. Limnology and Oceanography, v.14, p.454-458, 1969.

COELHO JUNIOR, C. Manguezal, Desenvolvimento estrutural da cobertura vegetal ao longo de gradientes de inundação, município de Cananéia, São Paulo, Brasil. São Paulo, 1998. 108p. Dissertação (Mestrado) - Instituto Oceanográfico, Universidade de São Paulo.

COMPANHIA DE TECNOLOGIA DE SANEAMENTO AMBIENTAL. Baixada Santista memorial descritivo - carta do meio ambiente e de sua dinâmica. São Paulo, 1976. 33p.

COMPANHIA DE TECNOLOGIA DE SANEAMENTO AMBIENTAL. Aterros sanitários em mangues na Baixada Santista. São Paulo, 1977. 30p. (Relatório interno CETESB).

COMPANHIA DE TECNOLOGIA DE SANEAMENTO AMBIENTAL. Considerações ecológicas sobre os mangues da Baixada Santista. São Paulo, 1979. 44p. (Relatório interno).

COMPANHIA DE TECNOLOGIA DE SANEAMENTO AMBIENTAL. Levantamento de subsídios para o gerenciamento de áreas costeiras ecologicamente sensíveis: Manguezais $\rightarrow$ Avaliação dos efeitos de um derramamento de óleo em áreas de manguezal, Bertioga. São Paulo, 1989. $110 p$.

COMPANHIA DE TECNOLOGIA DE SANEAMENTO AMBIENTAL. Sistema estuarino de Santos e São Vicente. São Paulo, 2001a. 179p.

COMPANHIA DE TECNOLOGIA DE SANEAMENTO AMBIENTAL. Relatório de estabelecimento de valores orientadores para solos e águas subterrâneas no Estado de São Paulo. São Paulo, 2001b. 247p.

CONSULTORIA PAULISTA DE ESTUDOS AMBIENTAIS. Estudo do Meio Biótico do Jardim Imperador - Praia GrandelSP. São Paulo, 2004. (Relatório Ambiental Prévio - RAP).

CORRÊA, F.M. Retranslocação e teores totais de macronutrientes em folhas das espécies de mangue de Guaratiba, Rio de Janeiro. São Paulo, 2003. 258p. Tese (Doutorado) - Instituto Oceanográfico, Universidade de São Paulo.

CORTESÃO, J.; BIGARELLA, J.J.; JOLY, C.A. et al. Mata Atlântica: atlantic rain forest. São Paulo: Ed. Index Ltda, Fundação SOS Mata Atlântica. 1991. 
CUNHA-LIGNON, M. Dinâmica do manguezal no Sistema de Cananéia-Iguape, Estado de São Paulo - Brasil. São Paulo, 2001. 57p. Dissertação (Mestrado) - Instituto Oceanográfico, Universidade de São Paulo.

CUZZUOL, G.R.F.; CAMPOS, A. Aspectos nutricionais na vegetação de manguezal do estuário do Rio Mucuri, Bahia, Brasil. Revista Brasileira de Botânica, v.24, n.2, p.227-234, 2001.

DASSIE, J.C.P. Recuperação de manguezal impactado por sedimentação. São Paulo: WS Arquitetura e Paisagismo, 1997. 9p. (Memorial descritivo).

DAVIS, J.H. The ecology and geologic role of mangrove in Florida. Washington: Carnegie Institute Washington Publication, 1940. p.303-412.

D'CROZ, L.; ROSARIO, J. Degradation of red mangrove (Rhizophora mangle L.) leaves in the Bay of Panama. Revista de Biologia Tropical, v.37, n.1, p.101-104, 1989.

DUKE, N.C.; PINZÓN, M.Z.S. Aging Rhizophora seedlings from leaf scar nodes: a technique for studying recruitment and growth in mangrove forests. Biotropica, v.24, n.2a, p.173-186, 1992.

EMPRESA BRASILEIRA DE PESQUISAS AGROPECUÁRIAS. Centro Nacional de Pesquisa de Solos. Levantamento de reconhecimento dos solos do Estado do Espírito Santo. Rio de Janeiro: EMBRAPA, 1978. 420p. (Boletim Técnico, 45).

EYSINK, G.G.J.; BACILIERI, S.; BERNARDO, M.P.S.L. et al. Recuperação de manguezais degradados através do uso de propágulos de Rhizophora mangle acondicionado em estufa. Arquivo do Instituto Biológico, v.64, p.195, 1997. Suplemento.

EYSINK, G.G.J.; BACILIERI, S.; SIQUEIRA, M.C. et al. Avaliação da manutenção da viabilidade de propágulos de Rhizophora mangle acondicionados em estufa, visando o seu uso na recuperação de manguezais degradados. In: SIMPÓSIO DE ECOSSISTEMAS BRASILEIRO, 4., Águas de Lindóia, 1998. Anais. Águas de Lindóia: ACIESP, 1998a. p.3847.

EYSINK, G.G.J.; BERARDO, M.P.S.L.; SILVA, L.S. et al. Replantio de plântulas de Laguncularia racemosa visando o seu uso em programas de recuperação de manguezais degradados. In: SIMPÓSIO DE ECOSSISTEMAS BRASILEIROS, 4., Águas de Lindóia, 1998. Anais. Águas de Lindóia: ACIESP, 1998b. p.48-55.

FAO. Mangrove management in Thailand, Malaysia and Indonesia. Rome,1994.

FIELD, C.D. Rehabilitation of mangrove ecosystems: an overview. Marine Pollution Bulletin, v.37, n.8/12, p.383-392, 1998. 
FLORES-VERDUGO, F.J.; GONZÁLEZ-FARIAS, F.; ZAMORANO, D.S. Mangrove ecosystems of the Pacific Coast of México: Distribution, structure, litterfall, and detritus dynamics. In: SEELIGER, U. (Ed). Coastal plant communities of Latin America. San Diego: Academic Press, 1992. p.269288.

FUNDAÇÃO ESTADUAL DE ENGENHARIA DO MEIO AMBIENTE. Os manguezais do Recôncavo da Baia de Guanabara. Rio de Janeiro: DECAM-DEPOL/FEEMA, 1979. 107p. (Cadernos FEEMA. Série técnica 10/79).

FUNDAÇÃO SOS MATA ATLÂNTICA. Atlas da evolução dos remanescentes florestais e ecossistemas associados do domínio de Mata Atlântica do Estado de São Paulo no período de 1985 - 1990. São Paulo: Fundação SOS Mata Atlântica; INPE; Ministério da Ciência e Tecnologia, 1992.

GRASSO, M.; TOGNELLA, M.M.P.; SCHAEFFER-NOVELLI, Y. et al. Aplicação de técnicas de avaliação econômica ao ecossistema manguezal. 155p., 1995.

HARBINSON, P. Mangrove mud: a sink and a souce for trace metals. Marine Pollution Bulletin, v.17, p.246-250, 1986.

HART, M.G.R. Sulfhur oxidation in tidal mangrove soils on Sierra Leone. Plant and Soil, v.3, p.215-236, 1959.

HERZ, R. Manguezais do Brasil. São Paulo: USP; IO, 1991, 227p.

HUERTA-DÍAZ, M.A.; MORSE, J.W. Pyritization of trace metals in anoxic marine sediments. Geochimica Cosmochimica Acta, v.56, p.2681-2702, 1992.

HUTCHINGS, P.A.; SAENGER, P. Ecology of mangroves. Brisbane: University of Queensland Press, 1987. 388p.

INSTITUTO FLORESTAL. Inventário Florestal do Estado de São Paulo. São Paulo:IF, SMA, 1993. 199p.

JIMENEZ, J.A. Rhizophora mangle L. Red mangrove. Rhizophoraceae. Mangrove family. Paris: UNESCO, SO-ITF-SM., 1985. 7p.

KRAUSKOPF, K.B. Factors controlling the concentrations of thirteen rare metals in sea waters. Geochimica Cosmochimica Acta, v.9, p.1-32, 1956.

LACERDA, L.D. de. Manguezais florestas de beira-mar. Ciência Hoje, v.3, n.13, p.53-59, jul./ago. 1984.

LACERDA, L.D. de; ABRÃO J.J. Heavy metal accumulation by mangrove and saltmarsh interdital sediments. Revista Brasileira de Botânica, n.7, p.49-52, 1984. 
LACERDA, L.D. de; RESENDE, C.E. de. Metals in the seagrass Halodule wrightii Aschers during one growing season. Revista Brasileira de Botânica, n.9, p.87-90, 1986.

LACERDA, L.D. de; SCHAEFFER-NOVELLI, Y. Mangrove of Latin America: the need for conservation and sustainable utilization. Mangrove ISME, News Letters, p.4-6, 1992.

LACERDA, L.D. de; CARVALHO, C.E.V.; TANIZAKI, K.F. et al. The biogeochemistry and trace metals distribution of mangrove rhizospheres. Biotropica, v.25, n.3, p.252-257, 1993.

LACERDA, L.D. de; MARTINELLI, L.A.; REZENDE, C.A. et al. The fate of trace metals in suspended matter in a mangrove creek during a tidal cycle. Science Total Environmental, v.75, p.249-259, 1988.

LAMBERTI, A. Contribuição ao conhecimento da ecologia das plantas do manguezal de Itanhaém. São Paulo, 1966. 222p. Tese (Doutorado) Faculdade de Filosofia, Ciências e Letras, Universidade de São Paulo.

LAMBERTI, A. Contribuição ao conhecimento da ecologia das plantas de manguezal de Itanhaém, São Paulo: USP, Faculdade Filosofia Ciências e Letras, 1969. (Boletim de Botânica, 23). 217p

LAMPARELLI, C.C.; MOURA, D.O.; RODRIGES, F.O. et al. Padrões ambientais dos manguezais de Bertioga (São Paulo-Brasil): subsídios para a avaliação de impactos. São Paulo: CETESB, 1997. 77p. (Atualização e aperfeiçoamento de metodologias analíticas para apoio às ações de controle de poluição e preservação de meio ambiente desenvolvidas pelo Governo do Estado de São Paulo).

LEONEL, C.; SIMÕES, E. Curso de integração: ambiente, preservação e educação. São Paulo: Secretaria do Meio Ambiente, s.d. 42p.

LEWIS III, R.R. Mangrove forests. In: COLE, D.P. (Ed). Creation and restoration of coastal plant communities. Boca Raton: CRC Press, 1982. p.154-171.

LUGO, A.E. Mangrove forests: a tough system to invade but a easy one to rehabilitate. Marine Pollution Bulletin, v.37, n.8-12, p.427-430, 1998.

LUIZ-SILVA, W; MATOS, R.H.R.; KRISTOSCH, G.C. Geoquímica e índice de geoacumulação de Mercúrio em sedimentos de superfície do Estuário de Santos, Cubatão. Química Nova, v.25, n.5, 10p, 2002. www. scielo.br. (12 fev. 2004).

MACEDO, L.A.A. Assimilação de esgotos em manguezais. São Paulo, 1986. 101p. Dissertação (Mestrado) - Faculdade de Saúde Pública, Universidade de São Paulo. 
MACEDO, L.A.A.; ROCHA, A.A. Lançamento de esgotos em manguezais: Considerações sobre aspectos ecológicos-sanitários na llha de São Luiz, MA. Revista DAE, v.45, n.140, p.67-72, Mar. 1985.

MACNAE, W. Zonation within mangroves associates with estuaries in North Queensland. In: LAUFF, G.H. (Ed.). Estuaries. Camberra: Am. Ass. Adv. Sci., 1968. p. 432-441.

MARIUS, C.; LUCAS, J. Holocene mangrove swamps of West África: sedimentology and soils. Journal African Earth Science, v.12, p.41-54, 1991.

MASCARENHAS, R.E.B. ; GAMA, J.R.N.F. Extensão e característica das áreas de mangue do litoral paraense. Belém: Embrapa Amazônia Oriental, 1999. 20p. (Série documentos, 2).

MASTALLER, M. Resumo da literatura sobre conceitos do uso de áreas de mangue, com referência especial para a aquicultura artesanal. Brasília: IBAMA, 1990. 79p.

MASUTTI, M.B.; PANITZ, C.M.N. O impacto ambiental do lixão desativado para o manguezal do Itacorubi, Florianópolis, SC. In: SIMPÓSIO DE ECOSSISTEMAS BRASILEIROS: Conservação, 5., Vitória, 2000. Anais. Vitória: ACIESP, 2000. v.2, p.303-310.

MEDICINA, 2004. http://www.medicinacomplementar.com.br/biblioteca doenças_vanadio.asp. (16 jan. 2005)

MENEZES, G.V. Produção e decomposição em bosques de mangue da llha do Cardoso, Cananéia, SP. São Paulo, 1994. 116p. Dissertação (Mestrado) Instituto Oceanográfico, Universidade de São Paulo.

MENEZES, G.V. Recuperação de manguezais: um estudo de caso na Baixada Santista, Estado de São Paulo, Brasil. São Paulo, 1999. 164p. Tese (Doutorado) - Instituto Oceanográfico, Universidade de São Paulo.

MENEZES, G.V.; POFFO, I.R.F.; EYSINK, G.G.J. Estudo sobre a viabilidade e diferentes técnicas de recuperação de manguezais degradados em Cubatão, SP. São Paulo: CETESB, 1998. 25p. (Relatório do Projeto: Desenvolvimento e Implantação de Novas Metodologias).

MENEZES, G.V.; POFFO, I.R.F.; EYSINK, G.G.J. et al. Manguezais: projeto de revegetação na Baixada Santista, SP, Brasil. In: SIMPÓSIO SUL AMERICANO DE RECUPERAÇÃO DE ÁREAS DEGRADADAS, 8., Foz de Iguaçu, 1994. Anais. Curitiba: FUPEF, 1994. p.543-553.

MENEZES, G.V.; POFFO, I.R.F.; EYSINK, G.G.J. et al. Restauração de um manguezal utilizando Laguncularia racemosa. In: CONGRESSO LATINOAMERICANO SOBRE CIÊNCIAS DO MAR, 7., Santos, 1997. Anais. Santos, 1997. p.164-165. 
MENEZES, G.V.; POFFO, I.R.F.; EYSINK, G.G.J. et al. Recuperação de manguezais degradados: o exemplo de Cubatão. In: IV ENCONTRO NACIONAL DE EDUCAÇÃO AMBIENTAL EM ÁREAS DE MANGUEZAL., 4., Nova Almeida-Serra, 1996. Resumos. Nova Almeida-Serra: UFES, 1996. p.65-66.

MENEZES, L.F.T. de; PEIXOTO, A.L.; MACIEL, N.C. A riqueza ameaçada dos mangues. Ciência Hoje, v.27, n.158, p.63-67, mar. 2000.

MITSCH, W.J.; GOSSEWLINK, J.G. Wetlands. New York: Van Rostrand Reinhold, 1993. 539p.

MOSCATELLI, M.; ALMEIDA, J.R. Avaliação de crescimento e sobrevivência de Rhizophora mangle em restauração de manguezais no município de Angra dos Reis, RJ. In: SIMPÓSIO SUL AMERICANO DE RECUPERAÇÃO DE ÁREAS DEGRADADAS, Foz de Iguaçu, 1994. Anais. Curitiba: FUPEF, 1994. p.487-498.

MOURA, D.O.; LAMPARELLI, C.C.; RODRIGUES, F.O.; et al. Decomposição de folhas em manguezais na região de Bertioga, São Paulo, Brasil. In: SIMPÓSIO DE ECOSSISTEMAS BRASILEIRO, 4., Águas de Lindóia, 1998. Anais. Águas de Lindóia: ACIESP, 1998. p.130-154.

NOVELLI, Y.S.; LACERDA, L.D. de. Lagoas costeiras, manguezais, marismas, dunas e restingas. In: PANITZ, C.M.N. (Coord.). Diagnóstico ambiental oceânico e costeiro das regiões Sul e Sudeste do Brasil. São Paulo: Fundespa; lousp; Petrobrás, 1994. p.128-347.

ODUM, H.T. Work circuits and system stress. In: SYMPOSIUM ON PRIMARY PRODUCTIVITY AND MINERAL CYCLING IN NATURAL ECOSYSTEMS, Orono Maine, 1967. Orono Maine: University of Marine Press, 1967. p.81138.

OLIVEIRA, R.R.; BRESSAN, F.A.; SILVA-FILHO, E.V. Contaminação por metais pesados no sedimento e em compartimentos bióticos de manguezais da Baía de Guanabara, RJ. In: SIMPÓSIO DE ECOSSISTEMAS BRASILEIRO,4., Águas de Lindóia, 1998. Anais. Águas de Lindóia: ACIESP, 1998. p.30-37.

ORGE, M.D.R. Crescimento de Rhizophora mangle L. em manguezais sob influência de atividades petroleiras na Baía de todos os Santos. Bahia, 1997. 96p. Dissertação (Mestrado) - Instituto de Biologia, Universidade Federal da Bahia.

PALUDO, D.; KLONOWSKI, V. S. Estudo do impacto do uso de madeira de manguezal pela população extrativista e da possibilidade de reflorestamento e manejo dos recursos madeireiros. Barra de Mamanguape, PB. São Paulo: IF, 1999. 54p. (Série Cadernos da Reserva da Biosfera). 
POR, F. D. The atlantic rain forest Brazil. The Hague: SPB Academic, 1992. $85 p$.

PROJETO RADAM BRASIL. Levantamento de Recursos Naturais. Rio de Janeiro, 1983. 780p. (v.32, Folhas SF 23/24 - Rio de Janeiro/Vitória).

RABINOWITZ, D. Dispersal properties of mangrove propagules. Biotropica, V.10, n.1, p.47-57, 1978a.

RABINOWITZ, D. Mortality and initial propagule size in mangrove seedlings in Panama. Journal of Ecology, v.66, p.45-51, 1978b.

RAMOS e SILVA, C.A.R. Manguezal: ecossistema egoísta ou benevolente? Ciência Hoje, v.20, n.120, p.6-11, 1996.

RANWELL, D.S. Ecology of salt marshes and sand dunes. London: Chapman \& Hall, 1972. 258p.

RIZZINI, C.T. Tratado da fitogeografia do Brasil. São Paulo: Hucitec; Edusp, 1979. v.2, 374p.

RODRIGUES, F.O. Derramamentos de óleo no ecossistema manguezal limpeza do ambiente, efeitos e metodologia de estudo. São Paulo, 1997. 173p. Dissertação (Mestrado) - Faculdade de Saúde Publica, Universidade de São Paulo.

RODRIGUES, F.O.; ROQUETTI-HUMAYTÁ, M.H. Estudo dos manguezais da Baixada Santista. São Paulo: CETESB, 1988. 70p. (Relatório Final).

RODRIGUES, F. O.; LAMPARELLI, C.C.; MOURA, D.O. Indicadores de qualidade ambiental - Padrões ambientais para manguezais impactados: efeitos de derramamento de óleo em áreas de manguezal. São Paulo: CETESB, 1990. 21p. (Relatório do Setor de bentos e manguezais).

RODRIGUES, F.O.; MOURA, D.O.; LAMPARELLI, C.C. Padrões ambientais para quantificação de alterações morfo-funcionais em manguezais impactados por óleo. São Paulo: CETESB, 1989. 49p. (Relatório Interno CETESB).

ROSSI, M.; MATTOS, I.F.A. O ecossistema mangue - Uma análise dos solos e da vegetação no Estado de São Paulo. In: CONGRESSO NACIONAL SOBRE ESSÊNCIAS NATIVAS, 2., São Paulo, 1992. Anais. São Paulo: IF, 1992. p.930-936.

SANTOS, M.M.; SCHAEFFER-NOVELLI, Y. Levantamento da flora e caracterização dos bosques de mangues do Estado de Sergipe. In: ENCONTRO BRASILEIRO DE GERENCIAMENTO COSTEIRO, 3. Fortaleza, 1985. Anais. Fortaleza: UFCE, 1985. p.325-336. 
SCHAEFFER-NOVELLI, Y. Manguezais brasileiros: região sudeste-sul. In: SIMPÓSIO SOBRE ECOSSISTEMAS BRASILEIROS DA COSTA SUL E SUDESTE: SÍNTESE DOS CONHECIMENTOS, Cananéia, 1987. Resumos. São Paulo: ACIESP, 1987. v.1, p.78.

SCHAEFFER-NOVELLI, Y. Manguezal: situação atual da pesquisa e a proteção ao ecossistema. In: SIMPÓSIO ANUAL DA ACIESP - O MEIO AMBIENTE: SUA OCUPAÇÃO E RECUPERAÇÃO,13., São Paulo, 1989. Anais. São Paulo: ACIESP,1989. n.67, p.160-163.

SCHAEFFER-NOVELLI, Y. Manguezal, os dispositivos legais como instrumento de conservação. In: SIMPÓSIO DE ECOSSISTEMAS BRASILEIROS: CONSERVAÇÃO, 4., Vitória, 2000. Anais. Vitória: ACIESP, 2000. v.1, p.1017.

SCHAEFFER-NOVELLI, Y. (Coord.). Manguezal ecossistema entre a terra e o mar. São Paulo: Caribbean Ecological Research, 1995. 64p.

SCHMIDT, G.; SCHAEFFER-NOVELLI, Y.; ADAIME, R.R. Ferro e Manganês em folhas de mangue em decomposição no Estuário de Cananéia, SP. In: SIMPÓSIO DE ECOSSISTEMAS BRASILEIROS, 4., Águas de Lindóia, 1998. Anais. Águas de Lindóia: ACIESP, 1998. p.95-101.

SEKAR, T.; KARUNAKARA, M.S.; JOSEPH, S. Preliminary studies on the regeneration of Rhizophora species in Pitchavaram mangroves, Taml Ndu. The Indian Forester, v.115, n.12, p.851-859, 1989.

SILVA, C.A.R.; LACERDA, L.D. de; REZENDE, C.E. Metais reservoir in a red mangrove Forest. Biotropica, v.22, n.4, p.339-345, 1990.

SILVA, E.V. da. Os impactos ambientais em um manguezal de franja no Ceará. In: CONGRESSO NORDESTINO DE ECOLOGIA, 1., Recife, 1986. Anais. Recife, 1986. p.152-160.

SILVA, I.X.; MORAES, R.P. de; SANTOS, R.P. dos et al. Avaliação do estado de degradação dos ecossistemas as Baixada Santista - SP. São Paulo: CETESB, 1991. 45p. (Relatório técnico, CETESB).

SILVA, I.X.; MORAES, R.P. de; SANTOS, R.P. dos et al. Avaliação do estado de degradação dos ecossistemas da Baixada Santista - SP. In: SIMPÓSIO DE ECOSSISTEMAS DA COSTA BRASILEIRA: SUBSÍDIOS A UM GERENCIAMENTO AMBIENTAL, Serra Negra, 1994. Anais. São Paulo: Publicação ACIESP, 1994. v.1, p.30-38.

SILVA, M.L.S. Biogeoquímica de elementos traço em solos de sistemas estuarinos: manguezais do Estado de São Paulo (Brasil) e marismas da Galícia (Espanha). Piracicaba, 2005. 147p. Tese (Doutorado) - Escola Superior de Agricultura Luiz de Queiros, Universidade de São Paulo. 
SINGH, B.P. Biodiversity conservation in mangrove environment. Indian Forester, p.827-836, Sept. 1994.

SMOAK, S.; PATCHINEELAM, S.R. Sedimentation rates in mangrove sediments from September Bay. Brazil. Mangroves \& Salt Marshes, v.3, p.98-103, 1999.

SOARES, M.L.G. Estudo da biomassa aérea de manguezais do Sudeste do Brasil - análise de modelos. São Paulo, 1997. Tese (Doutorado) - Instituto Oceanográfico, Universidade de São Paulo.

SOARES, M.L.G. Estrutura vegetal e grau de perturbação dos manguezais da Lagoa da Tijuca, Rio de Janeiro, RJ, Brasil. Química Nova, v.59, n.3, 18p., 1999. www. scielo.br. (12 fev. 2004).

SOARES, M.L.G; SCHAEFFER-NOVELLI,Y.; PERIA, L.C.S. et al. Modelos para estimativa da biomassa aérea de espécies de mangue no sudeste do Brasil. In: SIMPÓSIO DE ECOSSISTEMAS BRASILEIROS: CONSERVAÇÃO,5., Vitória, 2000. Anais. Vitória: ACIESP, 2000. p. 270-278.

SOTO, R.; JIMENEZ, J.A. Análisis fisionómica estructural del manglar de Puerto Soley, La Cruz, Guanacaste, Costa Rica. Revista Biología Tropical, v.30, p.161-168, 1982.

TAM, N.F.Y.; LI, S.H.; LAN, C.Y. et al. Nutrients and heavy metal concentrations of plants and sediments in Futian mangrove forest. Hydrobiologia, v.295, p.149-158, 1995.

TOMLINSON, P.B. The botany of mangroves. Cambridge: Cambridge University Press, 1986. 413p.

UNIVERSIDADE ESTADUAL PAULISTA. www.inorgan221.iq.unesp.br/ quimgeral/respostas/bioinorgan.html. (16 jan. 2005).

VANNUCCI, M. Os manguezais e nós: uma síntese de percepções. São Paulo: Edusp, 1999. 233p.

VARJABEDIAN, R. Impactos sobre os manguezais. In: SCHAEFFER-NOVELLI, Y. (Coord). Manguezal: ecossistema entre a terra e o mar. São Paulo: Caribbean Ecological Research, 1995. p.49-52.

VERGARA FILHO; LONDRES, W.; BOAS, V. et al.. Introdução ao saber dos povos da lama. In: ENCONTRO NACIONAL DE EDUCAÇÃO AMBIENTAL EM ÁREAS DE MANGUEZAL, 6., Nova Almeida - Serra, 1996. Resumos. Nova Almeida-Serra: UFES, 1996. p.22-29.

WALSH, G.E. Mangroves: a review. In: REIMHOLD, R.; QUEEN, W. (Ed.). Ecology of halophytes. New York: Academic Press, 1974. p.51-174.

WATSON, J.G. Mangrove forests of Malay Peninsula. Malayans Forest Record, v.6, p.1-275, 1928. 